\title{
BIODESSULFATAÇÃO COM POSTERIOR OXIDAÇÃO PARCIAL DO SULFETO EM REATORES OPERADOS EM BATELADAS SEQÜENCIAIS
}

\author{
ARIOVALDO JOSÉ DA SILVA
}

Tese apresentada à Escola de Engenharia de São Carlos, da Universidade de São Paulo, como parte dos requisitos para obtenção de título de Doutor em Hidráulica e Saneamento.

ORIENTADOR: Professor Associado Marcelo Zaiat

São Carlos

2005 
Ficha catalográfica preparada pela Seção de Tratamento da Informação do Serviço de Biblioteca - EESC/USP

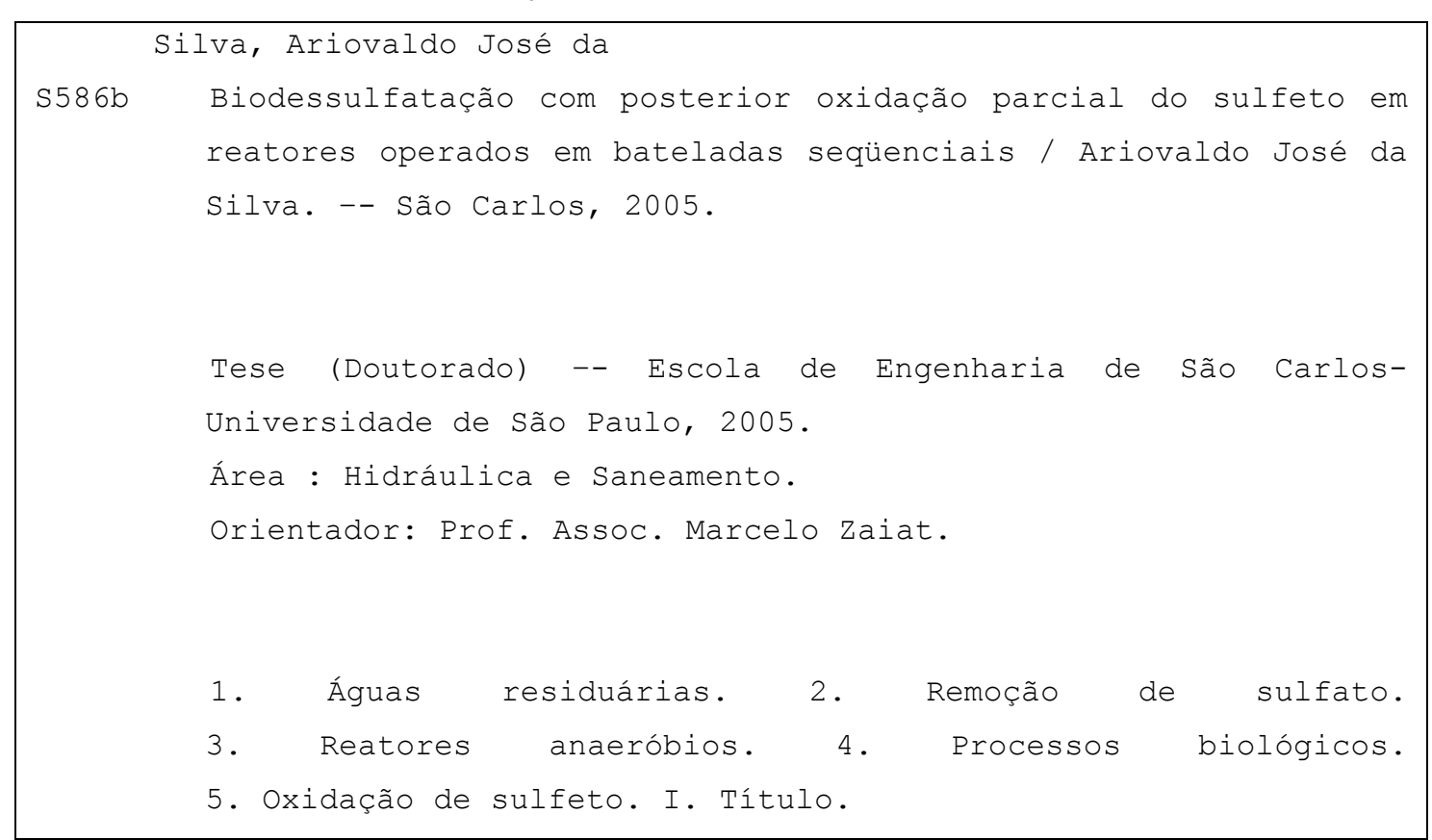




\section{FOLHA DE JULGAMENTO}

Candidato: Tecnólogo ARIOVALDO JOSÉ DA SILVA

Tese defendida e julgada em 18-02-2005 perante a Comissão Julgadora:

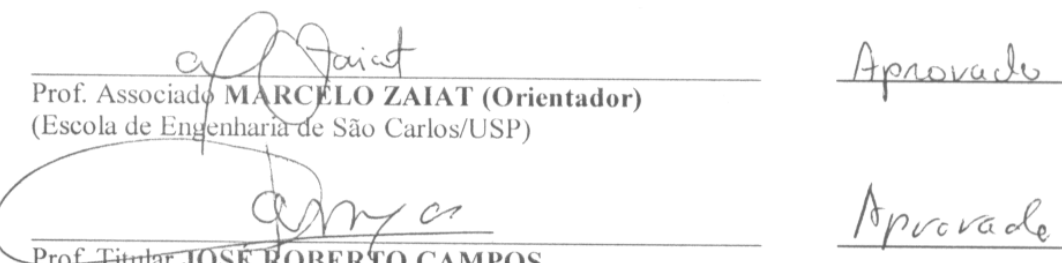

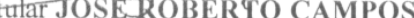

(Escola de Engenharia de São Carlos/USP)

$$
\text { Golson Silva }
$$

Prof. Dr. EDSON LUIZ SILVA

Aprovado

(Universidade Federal de São Carlos/UFSCar)

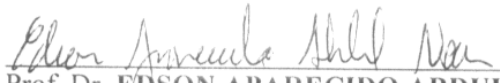

Prof. Dr. EDSON APARECIDO ABDUL NOUR

APRUAOD

(Universidade Estadual de Campinas/UNICAMP)

Prof. Dr. CARLOS AUGUSTO DE LEMOS CHERNICHARO

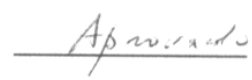

(Universidade Federal de Minas Gerais)

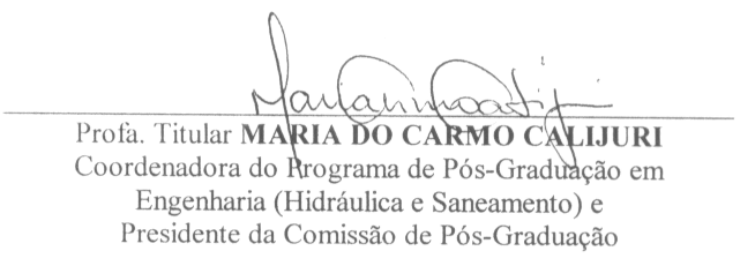




\section{DECLARAÇÃO UNIVERSAL DOS DIREITOS DA ÁGUA (ONU, 1992)}

1. A água faz parte do patrimônio do planeta. Cada continente, cada povo, cada região, cada cidade, cada cidadão é plenamente responsável aos olhos de todos.

2. A água é a seiva do nosso planeta. Ela é a condição essencial de vida e de todo ser vegetal, animal ou humano. Sem ela não poderíamos conceder como são a atmosfera, o clima, a vegetação, a cultura ou a agricultura. $\mathrm{O}$ direito à água é um dos direitos fundamentais do ser humano: o direito à vida, tal qual é estipulado no Art. 30 de Declaração Universal dos Direitos Humanos.

3. Os recursos naturais de transformação da água em água potável são lentos, frágeis e muito limitados. Assim sendo a água deve ser manipulada com racionalidade, preocupação e parcimônia.

4. O equilíbrio e o futuro de nosso planeta dependem da preservação da água e dos seus ciclos. Estes devem permanecer intactos e funcionando normalmente, para garantir a continuidade da vida sobre a Terra. Este equilíbrio depende, em particular, da preservação dos mares e oceanos por onde os ciclos começam.

5. A água não é somente uma herança dos nossos predecessores, ela é sobretudo um empréstimo aos nossos sucessores. Sua proteção constitui uma necessidade vital, assim como uma obrigação moral do Homem para as gerações presentes e futuras.

6. A água não é uma doação gratuita da natureza, ela tem um valor econômico: é preciso saber que ela é, algumas vezes, rara e dispendiosa e que pode muito bem escassear em qualquer região do mundo.

7. A água não deve ser desperdiçada, nem poluída, nem envenenada. De maneira geral, sua utilização deve ser feita com consciência e discernimento, para que não se chegue a uma situação de esgotamento ou de deterioração de qualidade das reservas atualmente disponíveis. 
8. A utilização da água implica o respeito à lei. Sua proteção constitui uma obrigação jurídica para todo o homem ou grupo social que a utiliza. Esta questão não deve ser ignorada nem pelo Homem nem pelo Estado.

9. A gestão da água impõe um equilíbrio entre os imperativos de sua proteção e as necessidades de ordem econômica, sanitária e social.

10. O planejamento da gestão da água deve levar em conta a solidariedade e o consenso em razão de sua distribuição desigual sobre a Terra.

Dedico esta tese à minha esposa Enza e às minhas filhas Stefani e Stella, que me proporcionam momentos de alegria e inspiração para viver. 


\section{AGRADECIMENTOS}

Ao Professor Associado Marcelo Zaiat, pela amizade, orientação e participação efetiva na elaboração deste trabalho.

Ao Professor Titular Eugenio Foresti pela orientação e apoio durante o desenvolvimento desse projeto, principalmente, pela possibilidade de eu fazer parte de seu competente grupo de pesquisa.

À Fundação de Amparo à Pesquisa do Estado de São Paulo -FAPESP pelo apoio e recursos financeiros concedidos

À Graduanda (Eng. Civil) Aline C. Tavares pela amizade e auxílio na operação dos reatores e análises físico-químicas durante o desenvolvimento de seu projeto de iniciação científica.

Ao grupo de óptica do IFSC, especialmente, ao Prof. Milton Ferreira de Souza pela disponibilidade do laboratório nas análises de ângulo de contato de materiais com água e ao Engō. Moacir M. Araújo Jr. pelo auxílio na medição dos ângulos de contato, como parte deste trabalho.

Aos funcionários da oficina mecânica da EESC/USP pela presteza na confecção dos reatores utilizados nessa pesquisa.

A TODOS os funcionários, professores e colaboradores do Departamento de Hidráulica e Saneamento da EESC/USP que de alguma forma contribuíram para a realização deste trabalho.

A TODOS os amigos do LPB pelos agradáveis momentos vividos durante o desenvolvimento desse trabalho. 


\section{SUMÁRIO}

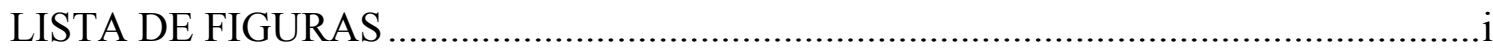

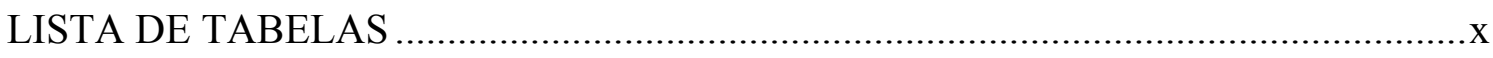

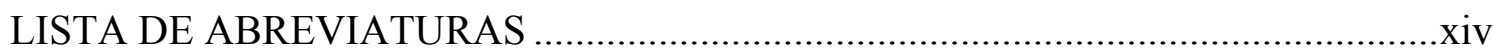

LISTA DE SÍMBOLOS .......................................................................................

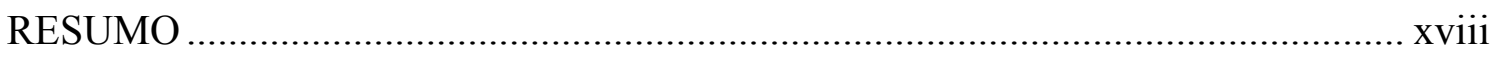

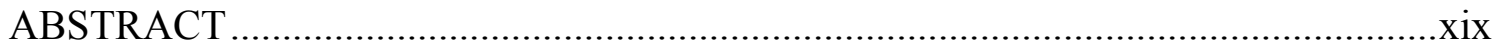

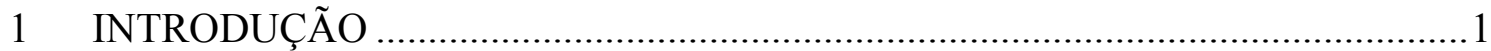

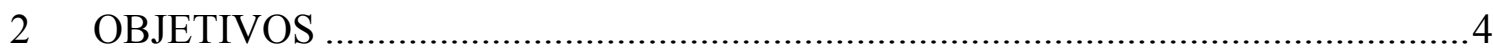

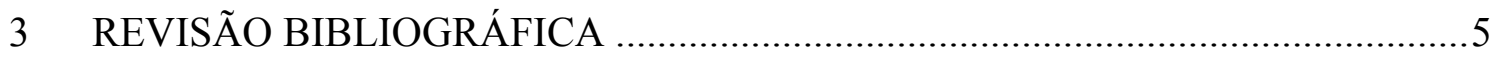

3.1 Origem do Enxofre e sua Utilização nas Atividades Antropogênicas.....................5

3.2 Fontes de Emissão de Sulfato e Contaminação das Águas ...................................6

3.3 Fontes Naturais de Emissão de Sulfato .....................................................................

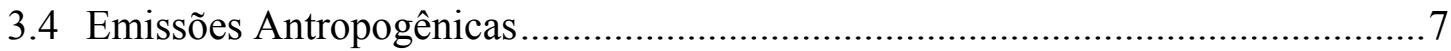

3.5 Fundamentos do Processo Biológico de Redução de Sulfato..................................8

3.6 Processos Biológicos de Remoção de Oxiânions de Enxofre com Oxidação

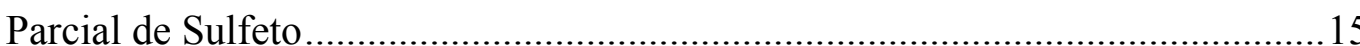

3.7 Reatores Utilizados para o Tratamento Biológico Anaeróbio de Águas Residuárias Contendo Sulfato. ........................................................................ 17

3.8 Fundamentos da Adesão Microbiana em Superfícies de Materiais Inertes..........20

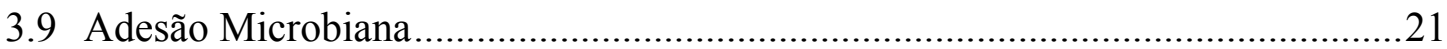

3.10 Interações Microbianas em Reatores Anaeróbios Tratando Águas Residuárias Contendo Sulfato

3.11 Efeitos do Sulfeto de Hidrogênio $\left(\mathrm{H}_{2} \mathrm{~S}\right)$ nos Processos Sulfetogênico e

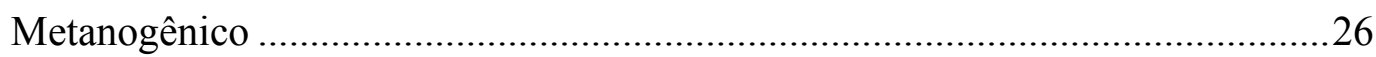

3.12 Remoção de Sulfeto de Águas Residuárias .......................................................29

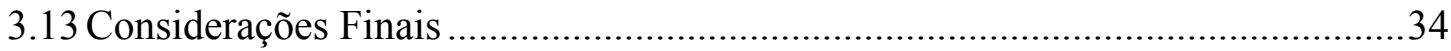




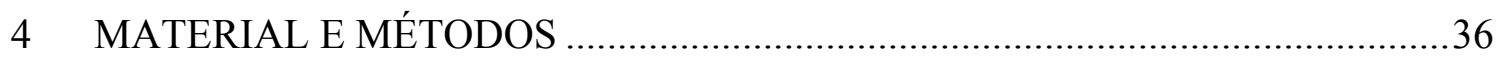

4.1 Ensaio de Imobilização da Biomassa em Materiais suporte Inertes......................36

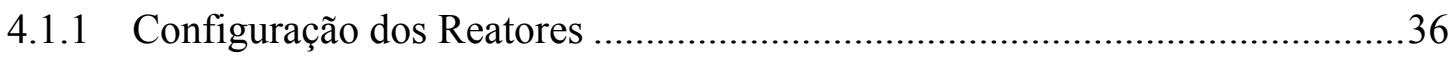

4.1.2 Materiais Utilizados como Suporte para Imobilização de Biomassa................37

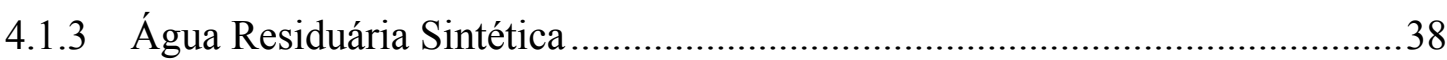

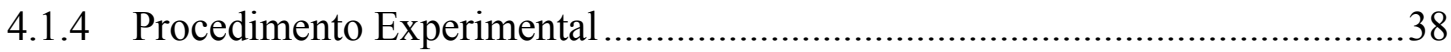

4.1.5 Monitoramento e Procedimentos Analíticos....................................................39

4.2 Operação dos Reatores em Batelada (ASBBR) - Processo de Biodessulfatação 40

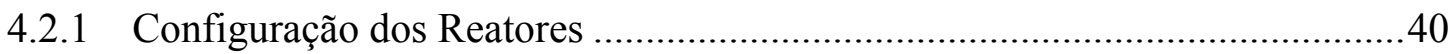

4.2.2 Materiais Suporte Utilizados para Imobilização de Microrganismos ...............42

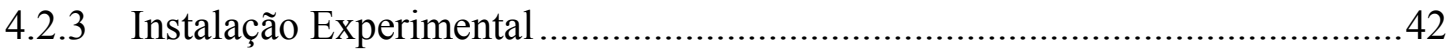

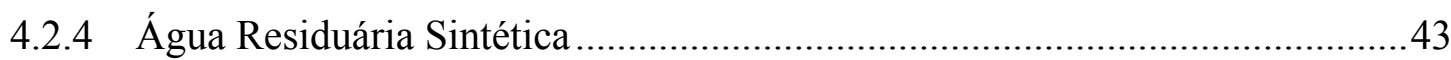

4.2.5 Monitoramento e Procedimentos Analíticos..................................................44

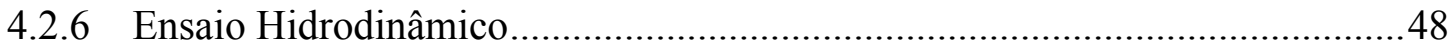

4.2.7 Avaliação do Desempenho dos ASBBR's no Tratamento de Água Residuária Sintética com Relações DQO/ $\mathrm{SO}_{4}{ }^{2-}$ de 3,2, 1,3, e 0,4 .......................49

4.2.8 Avaliação do Efeito de Etanol Sobre o Processo de Biodessulfatação.............51

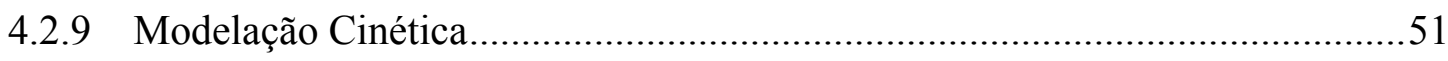

4.3 Oxidação Parcial do Sulfeto em Reator Aeróbio.....................................................53

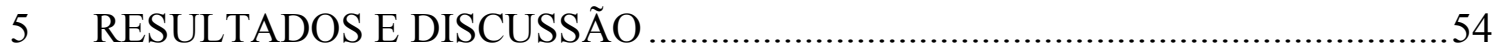

5.1 Ensaio de Imobilização de Biomassa em Suportes Inertes...................................54

5.1.1 Resultados das Análises Físico-Químicas......................................................54

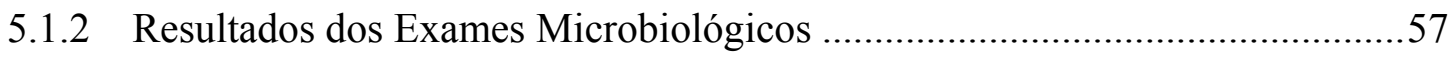

5.1.3 Resultados da Análise das Superfícies dos Materiais suporte e Biomassa -

Medição do Ângulo de Contato com Água .......................................................... 74

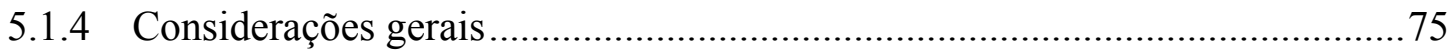

5.2 Ensaios Hidrodinâmicos nos Reatores Operados em Bateladas Seqüenciais........76

5.3 Desempenho do Reator com Espuma de Poliuretano (RE) no Tratamento de

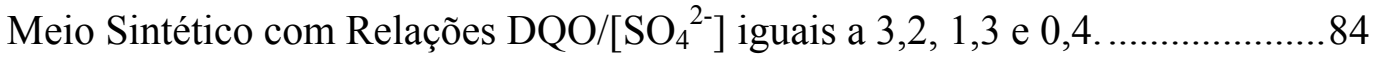

5.3.1 Alimentação com Relação DQO/[ $\left.\mathrm{SO}_{4}{ }^{2-}\right]$ Igual a 3,2 ..................................... 84

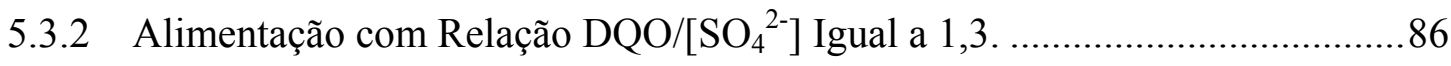

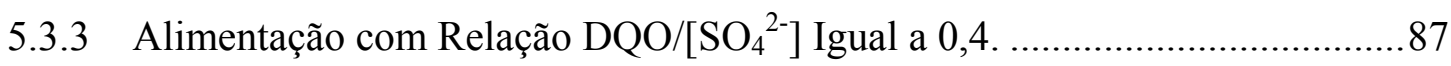


5.3.4 Considerações Gerais sobre o Estudo do Processo de Biodessulfatação em ASBBR Utilizando Espuma de Poliuretano como Material Suporte .

5.4 Desempenho do Reator com Carvão Vegetal (RC) no Tratamento de Meio

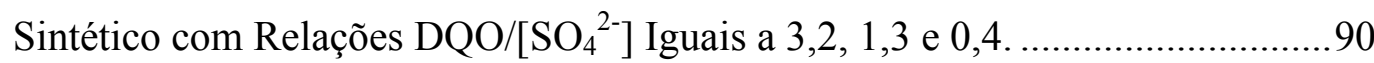

5.4.1 Alimentação com Relação DQO/[ $\left.\mathrm{SO}_{4}{ }^{2-}\right]$ Igual a 3,2 ......................................90

5.4.2 Alimentação com Relação DQO/[ $\left.\mathrm{SO}_{4}{ }^{2-}\right]$ Igual a 1,3 ....................................99

5.4.3 Alimentação com Relação DQO/[ $\left.\mathrm{SO}_{4}{ }^{2-}\right]$ Igual a 0,4 ...................................93

5.5 Considerações Gerais Sobre o Estudo do Processo de Biodessulfatação em ASBBR Utilizando Carvão Vegetal como Material Suporte

5.6 Comparação do Desempenho dos Reatores com Espuma de Poliuretano e

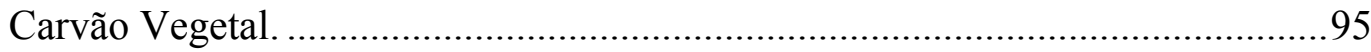

5.7 Retenção de Biomassa e Aspectos Microbiológicos ............................................96

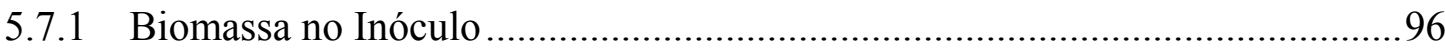

5.7.2 Biomassa no Reator com Espuma de Poliuretano .........................................98

5.7.3 Biomassa no Reator com Carvão Vegetal....................................................103

5.8 Avaliação do Efeito da Adição de Etanol no Meio Sintético Afluente................108

5.8.1 Adição de Etanol em Quantidade Estequiométrica em Relação à [ $\left.\mathrm{SO}_{4}{ }^{2-}\right] \ldots . .108$

5.8.2 Adição de Etanol em Quantidade Correspondendo ao Dobro da Estequiométrica

5.9 Modelação Cinética - Alimentação dos Reatores com Meio Sintético com Relações DQO/[ $\left[\mathrm{SO}_{4}{ }^{2-}\right]$ Igual a 3,2, 1,3, e 0,4

5.9.1 Reator com Espuma de Poliuretano (RE) Tratando Meio Sintético com Relação DQO/[ $\left.\mathrm{SO}_{4}{ }^{2-}\right]$ Igual a 3,2

5.9.2 Reator com Espuma de Poliuretano (RE) Alimentado com Meio Sintético com Relação DQO/[ $\left.\mathrm{SO}_{4}{ }^{2-}\right]$ Igual a 1,3

5.9.3 Reator com Espuma de Poliuretano (RE) Alimentado com Meio Sintético com Relação DQO/[SSO $\left.{ }_{4}{ }^{2-}\right]$ Igual a 0,4

5.9.4 Reator com Carvão Vegetal (RC) Tratando Meio Sintético com Relação $\mathrm{DQO} /\left[\mathrm{SO}_{4}{ }^{2-}\right]$ Igual a 3,2 .

5.9.5 Reator com Carvão Vegetal (RC) Alimentado com Meio Sintético com Relação DQO/[ $\left.\mathrm{SO}_{4}{ }^{2-}\right]$ Igual a 1,3 
5.9.6 Reator com Carvão Vegetal (RC) Alimentado com Meio Sintético com

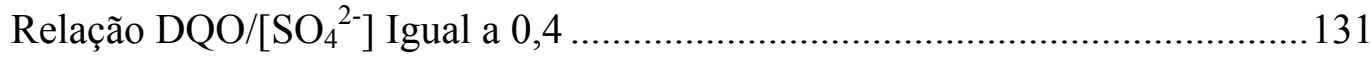

5.9.7 Considerações Gerais Sobre a Modelação Cinética......................................133

5.10 Modelação Cinética - Alimentação dos Reatores com Meio Sintético com

Relação DQO/[ $\left.\mathrm{SO}_{4}{ }^{2-}\right]$ Igual a 0,4 e com Adição de Etanol................................138

5.10.1 Reator com Espuma de Poliuretano (RE) .................................................138

5.11 Oxidação Parcial do Sulfeto em Reator Aeróbio....................................................142

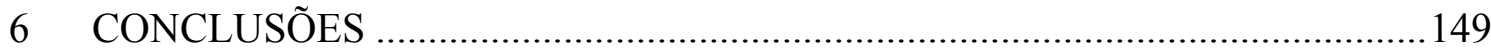

7 RECOMENDAÇÕES PARA TRABALHOS FUTUROS ENVOLVENDO O PROCESSO DE BIODESSULFURIZAÇÃO (REMOÇÃO DE SULFATO E

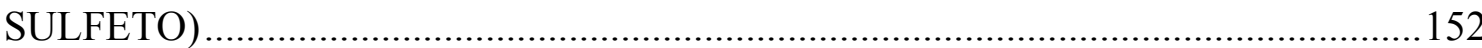

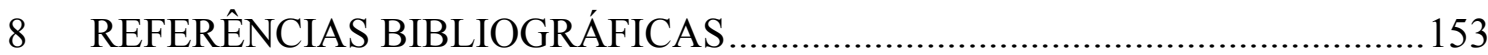




\section{LISTA DE FIGURAS}

Figura 3.1. Formas de Enxofre Encontradas na Natureza: a. Enxofre nativo; b.

Sulfeto de ferro (pirita); c. Sulfito de ferro (pirrotita). (Fonte: CDCC/USP) 6

Figura 3.2. Balanço das Emissões Naturais e Antropogênicas de Enxofre (Adaptado

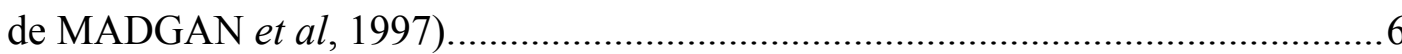

Figura 3.3. Redução Desassimilativa do Íon Sulfato (MADIGAN et al., 1997) ................8

Figura 3.4. Esquema de Operação do ASBR com Recirculação do Biogás. (1) Reator,

(2) Aspiração do Biogás, (3) Frasco p/ observação (4) Absorção de $\mathrm{H}_{2} \mathrm{~S}$, (5) Medidor de Biogás. B1, B2 e B3, correspondem aos bombeamentos de gás, efluente e afluente, respectivamente (Adaptado de Zaiat et al., 2001).

Figura 3.5. Ciclo Biológico do Enxofre (Adaptado de JANSEN et al., 1999).

Figura 3.6. Esquema de reator de leito expandido com unidade de aeração externa, utilizado para oxidação parcial de sulfeto e recuperação de enxofre elementar

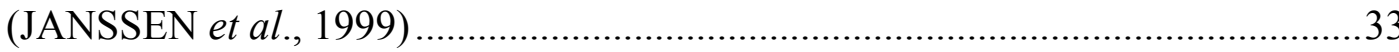

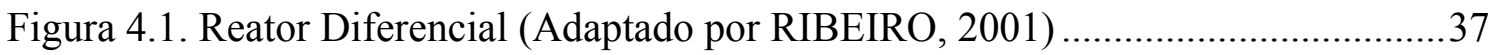

Figura 4.2. Instalação Experimental para Ensaios em Reatores Diferenciais:.................39

Figura 4.3. Reator Anaeróbio Utilizado para Operação em Bateladas Seqüenciais e com Biomassa Imobilizada em Material Suporte Inerte.........................................42

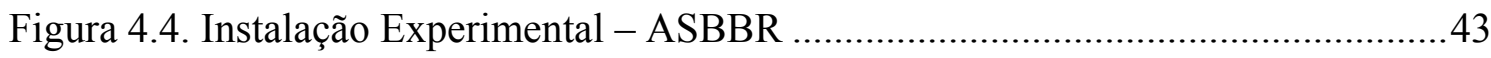

Figura 4.5. Lâmina de Vidro Revestida com Teflon Utilizada na Técnica de FISH. ......46

Figura 4.6. Aparato para Captação e Medição de Volume dos Gases dos ASBBR. .......50

Figura 4.7. Rota de Degradação de Compostos Orgânicos Monoméricos em Ambiente Anaeróbio com Presença de Sulfato (Adaptado de COLLERAN, 1995).

Figura 5.1. Concentração de Biomassa Aderida por mg de PU (Concentração Específica) nos Reatores Diferenciais.

Figura 5.2. Concentração Específica de Biomassa em: (a) CV, (b) CE e, (c) PE nos Reatores Diferenciais. 
Figura 5.3. Concentração Absoluta de Biomassa (STV) nos Reatores Diferenciais. .57

Figura 5.4. Morfologias Observadas por Meio de Microscopia Ótica, Luz Comum e Fluorescência, no Lodo Utilizado como Inóculo. (a) Filamentos Semelhantes a

Methanosaeta sp.; (b) Arranjo semelhante a Methanosarcina sp. .58

Figura 5.5. Composição da Comunidade Microbiana Determinada por FISH em Amostra do Lodo Utilizado como Inóculo. (HIRASAWA, 2003). .59

Figura 5.6. Morfologias Observadas por Meio de Microscopia Ótica de Luz Comum

e Fluorescência em Matrizes de PU Colonizadas Após 7 Dias de Operação. Bacilos Curtos com Extremidades Arredondadas, Bacilos com Extremidades Afiladas, Víbrios, Cocos e Bacilos Fluorescentes e Cocos Formando Arranjos Semelhantes a Methanosarcina sp.

Figura 5.7. Morfologias Observadas por Meio de Microscopia Ótica, Luz Comum e Fluorescência, em PU Após 14 Dias de Operação. Predomínio de Bacilos com Extremidades Arredondadas e Presença de Bacilos Fluorescentes.

Figura 5.8. Morfologias Observadas por Meio de Microscopia Ótica, Luz Comum e Fluorescência, em Matrizes de PU Após 21 Dias de Operação do Reator. Filamentos Semelhantes a Methanosaeta sp., Bacilos com Extremidades Arredondadas, Víbrios e Bacilos Fluorescentes.

Figura 5.9. Morfologias Observadas por Meio de Microscopia Ótica, Contraste de Fase e Fluorescência, em Matrizes de PU Após 28 Dias de Operação do Reator. Filamentos Semelhantes a Methanosaeta sp., Bacilos com Extremidades Arredondadas e Cocos Formando Arranjos Semelhantes a Methanosarcina sp.. ...62 Figura 5.10. Morfologias Observadas em PU. Após 7, 14, 21 e 28 Dias de Operação dos Reatores. Predomínio de Bacilos Curtos, com Extremidades Arredondadas, Presença de Víbrios e Cocos Formando Arranjos Semelhantes a Methanosarcina.sp. e Filamentos Semelhantes a Methanosaeta sp..

Figura 5.11. Morfologias Observadas por Meio de Microscopia Ótica, Luz Comum e Fluorescência, em Matrizes de CV Após 7 Dias de Operação do Reator. Filamentos Semelhantes a Methanosaeta sp., Bacilos com Extremidades Arredondadas, Células Ovóides, Bacilos Fluorescentes e Arranjos Semelhantes a Methanosarcina sp. 
Figura 5.12. Morfologias Observadas por Meio de Microscopia Ótica, Luz Comum e Fluorescência, em Matrizes de CV Após 14 Dias de Operação do Reator. Bacilos com Extremidades Arredondadas, Células Ovóides, Arranjos Semelhantes a Methanosarcina sp.....

Figura 5.13. Morfologias Observadas por Meio de Microscopia Ótica Utilizando Luz Comum e com Fluorescência em Matrizes de CV Colonizadas Após 21 Dias de Operação (Arranjos Semelhantes a Methanosarcina sp., Bacilos Com Extremidades Arredondadas, Bacilos com Extremidades Afiladas, Células Ovóides.

Figura 5.14. Morfologias Observadas por Meio de Microscopia Ótica, Utilizando Luz Comum e Fluorescência, em Matrizes de CV Após 28 Dias de Operação do Reator. Arranjos Semelhantes a Methanosarcina sp., Bacilos com Extremidades Arredondadas, Bacilos com Extremidades Afiladas, Células Ovóides, Filamentos Semelhantes a Methanosaeta sp. e Bacilos Fluorescentes.

Figura 5.15. Morfologias Observadas por Microscopia Eletrônica de Varredura em Amostras de CV Após 7, 14, 21 e 28 Dias de Operação dos Reatores. Predomínio de Bacilos com Extremidades Arredondadas e Células Ovóides e,

Presença de Cocos Formando Cadeias e Víbrios. .66

Figura 5.16. Morfologias Observadas por Meio de Microscopia Ótica Utilizando Luz Comum e Fluorescência, em Matrizes de PE, Após 7 Dias de Operação do Reator. Filamentos Semelhantes a Methanosaeta sp., Bacilos Fluorescentes, Víbrios, Bacilos Curtos com Extremidades Arredondadas e Células Ovóides.

Figura 5.17. Morfologias Observadas por Meio de Microscopia Ótica, Utilizando Luz Comum e Fluorescência, em Matrizes de PE Após 14 Dias de Operação do Reator. Arranjos Semelhantes a Methanosarcina sp.....

Figura 5.18. Morfologias Observadas por Meio de Microscopia Ótica, Utilizando Luz Comum e Fluorescência, em Matrizes de PE Após 21 Dias de Operação do Reator. Arranjos Semelhantes a Methanosarcina sp., Filamentos Semelhantes a Methanosaeta sp., Bacilos com Extremidades Arredondadas e Diplococos.

Figura 5.19. Morfologias Observadas por Meio de Microscopia Ótica, Utilizando Luz Comum e Fluorescência, em Matrizes de PE Após 28 Dias de Operação do Reator. Arranjos Semelhantes a Methanosarcina sp., Filamentos Semelhantes a 
Methanosaeta sp., Bacilos com Extremidades Arredondadas, Víbrios, e Células Ovóides.

Figura 5.20. Morfologias Observadas em Matrizes de Polietileno de Baixa Densidade Após 7, 14, 21 e 28 Dias de Operação do Reator. Predomínio de Morfologias Semelhantes a Metanosarcina sp. e Presença de Bacilos com Extremidades Arredondadas, e Células Ovóides.

Figura 5.21. Morfologias Observadas por Microscopia Ótica, Utilizando Luz Comum

e Fluorescência, em Matrizes de CE Após 7 Dias de Operação. Arranjos Semelhantes a Methanosarcina sp., Filamentos Semelhantes a Methanosaeta $s p$. .e Bacilos Fluorescentes.

Figura 5.22. Morfologias Observadas por Microscopia Ótica, Contraste de Fase e Fluorescência, em Matrizes de CE Após 14 Dias de Operação. Arranjos Semelhantes a Methanosarcina sp., Filamentos Semelhantes a Methanosaeta $s p$., Bacilos Fluorescentes, Víbrios, Bacilos Curtos com Extremidades Arredondadas, Células Ovóides e Bacilos em Cadeia.

Figura 5.23. Morfologias Observadas por Microscopia Ótica, Utilizando Luz Comum e Fluorescência, em Matrizes de CE Após 21 Dias de Operação do Reator. Arranjos Semelhantes a Methanosarcina sp., Bacilos Fluorescentes, Víbrios, Bacilos Curtos com Extremidades Arredondadas e Células Ovóides.

Figura 5.24. Morfologias Observadas por Microscopia Ótica, Utilizando Luz Comum e Fluorescência, em Matrizes de CE Após 28 Dias de Operação do Reator. Arranjos Semelhantes a Methanosarcina sp., Filamentos Semelhantes a Methanosaeta sp., Bacilos Fluorescentes, Víbrios, Bacilos Curtos com Extremidades Arredondadas e Células Ovóides.

Figura 5.25. Morfologias Observadas em CE, Após 7, 14, 21 e 28 Dias de Operação do Reator: Predomínio de Bacilos com Extremidades Arredondadas, Presença de Víbrios, Células Ovóides e Methanosaeta Sp.

Figura 5.26. Composição da Comunidade Microbiana, Determinada por Meio de FISH em Amostras de Matrizes Colonizadas nos Reatores Após: 7, 14, 21 E 28 Dias de Operação com (A) PU, (B) CV, (C) PE e (D) CE. Porcentagens Relativas de Células Pertencentes aos Domínios: Bacteria (EUB338), BRS 
(SRB385) e Arqueas (ARC915). As Barras de Erros Indicam os Erros-Padrão (HIRASAWA, 2003).

Figura 5.27. Ajuste Médio do Modelo de Boltzmann aos Valores Normalizados dos Dados Experimentais, Obtidos no Perfil Hidrodinâmico do Reator Preenchido com CV Sob Freqüência de Agitação de 90 rpm.

Figura 5.28. Ajuste Médio d Modelo de Boltzmann aos Valores Normalizados dos Dados Experimentais, Obtidos no Perfil Hidrodinâmico do Reator Preenchido com CV Sob Freqüência de Agitação de 180 rpm.

Figura 5.29. Ajuste Médio do Modelo de Boltzmann aos Valores Normalizados dos

Dados Experimentais Obtidos no Perfil Hidrodinâmico do Reator Preenchido com CV Sob Freqüência de Agitação de 300 rpm.

Figura 5.30. Ajuste Médio do Modelo de Boltzmann aos Valores Normalizados dos Dados Experimentais, Obtidos no Perfil Hidrodinâmico do Reator Preenchido com CV Sob Freqüência de Agitação de 500 Rpm

Figura 5.31. Ajuste Médio do Modelo de Boltzmann aos Valores Normalizados dos

Dados Experimentais, Obtidos no Perfil Hidrodinâmico do Reator Preenchido com CV Sob Freqüência de Agitação de 800 rpm.

Figura 5.32. Ajuste Médio Do Modelo de Boltzmann aos Valores Normalizados dos

Dados Experimentais, Obtidos no Perfil Hidrodinâmico do Reator Preenchido com PU Sob Freqüência de Agitação de 90 rpm

Figura 5.33. Ajuste Médio do Modelo de Boltzmann aos Valores Normalizados dos

Dados Experimentais, Obtidos no Perfil Hidrodinâmico do Reator Preenchido com PU Sob Freqüência de Agitação de 180 rpm.

Figura 5.34. Ajuste Médio do Modelo de Boltzmann aos Valores Normalizados dos Dados Experimentais, Obtidos no Perfil Hidrodinâmico do Reator Preenchido com PU Sob Freqüência de Agitação de 300 rpm

Figura 5.35. Ajuste Médio do Modelo de Boltzmann aos Valores Normalizados dos Dados Experimentais, Obtidos no Perfil Hidrodinâmico do Reator Preenchido com PU Sob Freqüência de Agitação de 500 rpm.

Figura 5.36. Ajuste Médio do Modelo de Boltzmann aos Valores Normalizados dos Dados Experimentais, Obtidos no Perfil Hidrodinâmico do Reator Preenchido com PU Sob Freqüência de Agitação de 800 rpm. 
Figura 5.37. Tempo de Mistura em Função da Freqüência de Agitação. .83

Figura 5.38. Eficiências de Remoção de Sulfato e DQO no Reator com Espuma de Poliuretano Tratando Meio Sintético com

Figura 5.39. DQO e Concentrações de Ácidos Totais Voláteis no Efluente do Reator

Contendo Espuma de Poliuretano, Tratando Meio Sintético com Relação $\mathrm{DQO} /\left[\mathrm{SO}_{4}{ }^{2-}\right]$ igual a3,2.

Figura 5.40. Eficiências de Remoção de Sulfato e de DQO no Reator com Espuma de

Poliuretano Tratando Meio Sintético com Relação DQO/[SO $\left.{ }_{4}{ }^{2-}\right]$ igual a1,3

Figura 5.41. Eficiências de Remoção de Sulfato e de DQO no Reator com Espuma de

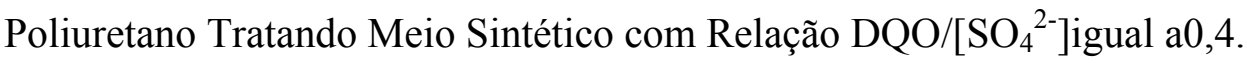
88

Figura 5.42. Eficiências em Remoção de Sulfato e de DQO no Reator com Carvão

Vegetal Tratando Meio Sintético com Relação DQO/[ $\left.\mathrm{SO}_{4}{ }^{2-}\right]$ igual a3,2.

Figura 5.43. Valores de DQO e Concentração de Ácidos Totais Voláteis em Função dos Ciclos Operacionais do Reator RC Tratando Meio Sintético com Relação $\mathrm{DQO} /\left[\mathrm{SO}_{4}{ }^{2-}\right]$ igual a3,2.

Figura 5.44. Eficiências em Remoção de Sulfato e de DQO no Reator com Carvão

Vegetal Tratando Meio Sintético com Relação DQO/[ $\left[\mathrm{SO}_{4}{ }^{2-}\right]$ igual a1,3.

Figura 5.45. Eficiências em Remoção de Sulfato e de DQO no Reator com Carvão

Vegetal Tratando Meio Sintético com Relação DQO/[ $\left.\mathrm{SO}_{4}{ }^{2-}\right]$ igual a 0,4.

Figura 5.46. Morfologias Semelhantes a Arqueas Metanogênicas, Observadas no Inóculo por Microscopia Ótica. (A) Arranjos Semelhantes a Methanosarcina sp. Observados a Luz Comum; (B) Arranjos Semelhantes a Methanosarcina sp. e Bacilos Observados com Fluorescência.

Figura 5.47. Morfologias Observadas por Microscopia Ótica com Luz Comum no Inóculo. (A) Filamentos Semelhantes a Methanosaeta.sp., Bacilos com Extremidades Arredondadas. (B) Bacilos Ovalados, Cocos, Bacilos Curvos (Víbrios).

Figura 5.48. Composição da comunidade microbiana presente no inóculo. As porcentagens celulares são representadas pela quantidade de RNAr $16 \mathrm{~S}$ microbiano para os membros pertencentes ao Domínios Bactéria (EUB338) e Archaea (Arc915)...... 
Figura 5.49. Morfologias Observadas em PU. (A) Tratamento do meio sintético com relação $\mathrm{DQO} /\left[\mathrm{SO}_{4}{ }^{2-}\right]$ igual a 3,2: bacilos curvos, bacilos delgados, bacilos ovalados, cocos, filamento semelhante a Methanosaeta sp.. (B) Tratamento do meio sintético com relação $\mathrm{DQO} /\left[\mathrm{SO}_{4}{ }^{2-}\right.$ igual a 1,3 : bacilos com extremidades afiladas, bacilos curvos, bacilos ovalados, bacilos com grânulos, cocos. (C) Tratamento do meio sintético com relação $\mathrm{DQO} /\left[\mathrm{SO}_{4}{ }^{2-}\right.$ igual a 0,4 : víbrios. 101

Figura 5.50. Porcentagem de Eubactérias, Bactérias Redutoras de Sulfato, e Arqueas Metanogênicas Detectadas por FISH na Biomassa Imobilizada em Espuma de Poliuretano, Após o Tratamento de Água Residuária Sntética com

Figura 5.51. Porcentagem de Eubactérias e Bactérias Redutoras de Sulfato Detectadas por FISH na Biomassa Imobilizada em Espuma de Poliuretano, Após o Tratamento de Água Residuária Sntética com Relação DQO/[ $\mathrm{SO}_{4}{ }^{2-}$ ].Igual a 0,4 . 103

Figura 5.52. Morfologias Observadas em Carvão Vegetal. (A) Etapa de operação tratando meio sintético com relação $\mathrm{DQO} /\left[\mathrm{SO}_{4}{ }^{2-}\right]$ igual a 3,2: bacilos curvos, bacilos delgados, bacilos ovalados, cocos. (B) Etapa de operação tratando meio sintético com relação DQO/[ $\left.\mathrm{SO}_{4}{ }^{2-}\right]$ igual a 1,3 : bacilos curvos, bacilos ovalados. (C) Etapa de operação tratando meio sintético com relação $\mathrm{DQO} /\left[\mathrm{SO}_{4}{ }^{2-}\right]$ igual a 0,4 : víbrios e cocos. .106

Figura 5.53. Porcentagem de Eubactérias, Bactérias Redutoras de Sulfato, e Arqueas Metanogênicas Detetctadas por FISH na Biomassa Imobilizada em Carvão Vegetal, Após o Tratamento de Água Residuária Sntética com.

Figura 5.54. Porcentagem de Eubactérias e Bactérias Redutoras de Sulfato Detectadas por FISH na Biomassa Imobilizada em Carvão Vegetal, Após o Tratamento de Água Residuária Sintética com Relação DQO/[SSO $\left.{ }_{4}{ }^{2-}\right]$.Igual a 0,4.108 Figura 5.55. Diagrama do Modelo Cinético Simplificado para Descrição das Rotas de Utilização de Substratos Orgânicos em Reatores Anaeróbios com Presença de Sulfato.

Figura 5.56. Ajuste do Modelo Cinético aos Valores Medidos nos Perfis Temporais das Variáveis: CS1, CS2 e CS3 no Reator com Espuma de Poliuretano Tratando Meio Sintético com Relação $\mathrm{DQO} /\left[\mathrm{SO}_{4}{ }^{2-}\right]$ igual a 3,2. (T) indica os valores calculados pelo modelo e (E) indica os valores empíricos. 
Figura 5.57. Perfil Temporal das Velocidades Aparentes, de Consumo de Substratos

Orgânicos, no Reator com Espuma de Poliuretano Tratando Meio Sintético com Relação DQO/[ $\left.\mathrm{SO}_{4}{ }^{2-}\right]$ igual a 3,2.

Figura 5.58. Ajuste do Modelo Cinético aos Valores Medidos nos Perfis Temporais das Variáveis: DQO, Ácido Acético como DQO e Sulfato no Reator com Espuma de Poliuretano Tratando Meio Sintético com Relação DQO/[ $\left.\mathrm{SO}_{4}{ }^{2-}\right]$ igual a 1,3 .

Figura 5.59. Perfil das Velocidades Aparentes, de Consumo de Substratos Orgânicos, no Reator com Espuma de Poliuretano (RE) Tratando Meio Sintético com

Figura 5.60. Ajuste do Modelo Cinético aos Valores Medidos nos Perfis Temporais das Variáveis: CS1, CS2 e CS3 no Reator com Espuma de Poliuretano (RE) Tratando Meio Sintético com Relação DQO/[ $\left[\mathrm{SO}_{4}{ }^{2-}\right]$ igual a 0,4 .

Figura 5.61. Perfil Temporal das Velocidades de Consumo de Substratos Orgânicos no Reator com Espuma de Poliuretano Tratando Meio Sintético com Relação $\mathrm{DQO} /\left[\mathrm{SO}_{4}{ }^{2-}\right]$ igual a 0,4 .

Figura 5.62. Ajuste do Modelo Cinético aos Valores Medidos nos Perfis Temporais das Variáveis: CS1, CS2 e CS3 no Reator com Carvão Vegetal (RC) Tratando Meio Sintético com Relação DQO/[ $\left.\mathrm{SO}_{4}{ }^{2-}\right]$ igual a 3,2.

Figura 5.63. Perfil das Velocidades de Consumo de Substratos Orgânicos no Reator com Carvão Vegetal (RC) Tratando Meio Sintético com

Figura 5.64. Ajuste do Modelo Cinético aos Valores Medidos nos Perfis Temporais das Variáveis: S1, S2 e S3 no Reator com Carvão Vegetal (RC) Tratando Meio Sintético com Relação DQO/[ $\left[\mathrm{SO}_{4}{ }^{2-}\right]$ igual a 1,3 .

Figura 5.65. Perfis Temporais das Velocidades de Consumo de Substratos Orgânicos no Reator com Carvão Vegetal Tratando Meio Sintético com Relação $\mathrm{DQO} /\left[\mathrm{SO}_{4}{ }^{2-}\right]$ igual a 1,3 .

Figura 5.66. Ajuste do Modelo Cinético aos Valores Medidos nos Perfis Temporais das Variáveis: CS1, CS2, e CS3 no Reator com Carvão Vegetal (RC) Tratando Meio Sintético com Relação DQO/[ $\left[\mathrm{SO}_{4}{ }^{2-}\right]$ igual a 0,4 .

Figura 5.67. Perfil das Velocidades de Consumo de Substratos Orgânicos no Reator com Carvão Vegetal (RC) Tratando Meio Sintético com 
Figura 5.68. Ajuste do Modelo Cinético aos Valores Medidos nos Perfis Temporais das Variáveis: CS1, CS2 e CS3 no Reator com Espuma de Poliuretano (RE) Tratando Meio Sintético com Relação DQO/[ $\left.\mathrm{SO}_{4}{ }^{2-}\right]$ igual a 0,4 e Etanol.

Figura 5.69. Perfil Temporal da Velocidade Aparente, de Consumo de Substratos Orgânicos $\left(\mathrm{r}_{\mathrm{ap}}\right)$ no Reator com Espuma de Poliuretano Tratando Meio Sintético com Relação DQO/[ $\left.\mathrm{SO}_{4}{ }^{2-}\right]$ igual a 0,4 . 140

Figura 5.70. Ajuste do Modelo Cinético aos Valores Medidos nos Perfis Temporais das Variáveis: DQO, Hac como DQO e Sulfato no Reator com Carvão Vegetal Tratando Meio Sintético com Relação DQO/[$\left[\mathrm{SO}_{4}{ }^{2-}\right]$ igual a 0,4 .

Figura 5.71. Perfil da Velocidades de Utilização de S1 por BRS no Reator com

Carvão Vegetal Tratando Meio Sintético com Relação DQO/[ $\left[\mathrm{SO}_{4}{ }^{2-}\right]$ igual a 0,4. 142

Figura 5.72. Concentração de Sulfato nos Reatores Sulfetogênico (R1) e Aeróbio

(R2) ao Longo dos Ciclos Realizados. 144

Figura 5.73. Concentração de Sulfeto nos Reatores Sulfetogênico (R1) e Aeróbio (R2), e da Eficiência em Remoção de Sulfeto no Reator Aeróbio (ER2) ao Longo dos Ciclos Realizados.

Figura 5.74. Ajuste de Modelo Cinético de Primeira Ordem aos Valores de Concentração de Sulfeto Total Obtidos no Perfil Temporal do Reator R2 145

Figura 5.75. Intensidade da Quantidade de Energia Detectada pelo Equipamento de EDXRF em Amostras Coletadas na Altura Superior do Reator. 146

Figura 5.76. Intensidade da Quantidade de Energia Detectada pelo Equipamento de EDXRF em Amostras Coletadas na Altura Central do Reator.

Figura 5.77. Intensidade da Quantidade de Energia Detectada pelo Equipamento de EDXRF em Amostras Coletadas na Altura Inferior do Reator. 147

Figura 5.78. Reator Sulfetogênico, ASBBR (1) e Reator Aeróbio, SBBR (2). 148 


\section{LISTA DE TABELAS}

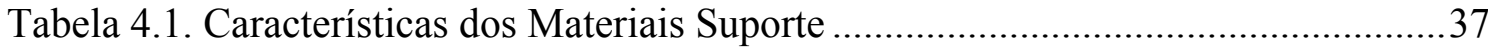

Tabela 4.2. Sondas de Oligonucleotídeos Utilizadas na Hibridação in situ.....................45

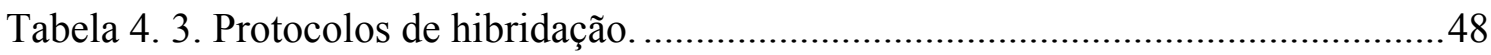

Tabela 5.1. Valores de DQO obtidos ao final das bateladas. Os valores das eficiências em remoção de DQO (\%) são apresentados entre parênteses.................54

Tabela 5.2. Concentrações de Sulfato no Efluente dos Reatores Diferenciais. ................55

Tabela 5. 3. Caracterização Morfológica do Inóculo por Microscopia Ótica...................58

Tabela 5.4. Caracterização Morfológicas dos Microrganismos Aderidos em Espuma

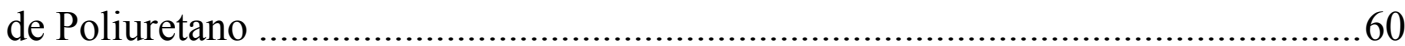

Tabela 5.5. Caracterização Morfológica dos Microrganismos Aderidos em CV .............64

Tabela 5.6. Caracterização Morfológica dos Microrganismos Aderidos em Polietileno de Baixa Densidade (Reciclado).......................................................67

Tabela 5.7. Caracterização Morfológica dos Microrganismos Aderidos em Cerâmica

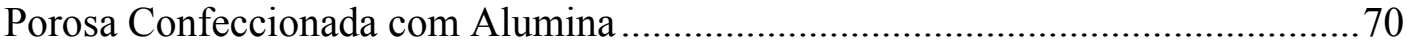

Tabela 5.8. Valores da Constante de Tempo $(\tau)$, do Centro da Sigmóide $\left(\mathrm{t}_{0}\right)$ e do Tempo de Mistura $\left(\mathrm{t}_{\mathrm{m}}\right)$, Calculados pelo Modelo de Boltzmann, para as Velocidades de Agitação Aplicadas ao Reator Contendo CV.

Tabela 5.9. Valores da Constante de Tempo $(\tau)$, do Centro da Sigmóide $\left(\mathrm{t}_{0}\right)$ e do Tempo de Mistura $\left(\mathrm{t}_{\mathrm{m}}\right)$, Calculados pelo Modelo de Boltzmann, para as Velocidades de Agitação Aplicadas ao Reator Contendo PU.

Tabela 5.10. Valores Médios das Variáveis Monitoradas no Efluente do Reator Contendo Espuma de Poliuretano como Material Suporte.

Tabela 5.11. Valores Médios das Variáveis Monitoradas no Efluente do Reator Contendo Carvão Vegetal como Material Suporte. ..................................................94

Tabela 5.12. Morfologias Observadas no Inóculo e Freqüências. ...................................96 Tabela 5.13. Quantificação da Biomassa Aderida em Espuma de Poliuretano no ASBBR 
Tabela 5.14. Morfologias Observadas em Espuma de Poliuretano e suas Freqüências. 100

Tabela 5.15. Quantificação da Biomassa Aderida em Carvão Vegetal no ASBBR ......104

Tabela 5.16. Morfologias Observadas em Carvão Vegetal no Final do Tratamento de

Meio Sintético com Relação DQO/[ $\left.\mathrm{SO}_{4}{ }^{2-}\right]: 3,2,1,3$, e 0,4 . 105

Tabela 5.17. Valores das Variáveis Químicas Monitoradas no Afluente dos Reatores Alimentados com Meio Sintético com Relação DQO/[SSO $\left.{ }_{4}{ }^{2-}\right]$ igual a0,4 e Etanol em Quantidade Estequiométrica.

Tabela 5.18. Valores das Variáveis Monitoradas no Efluente do Reator com Espuma de Poliuretano Alimentado com Meio Sintético e Etanol Sendo Adicionado em Quantidade Estequiométrica Relacionada a Concentração de Sulfato.

Tabela 5.19. Valores das Variáveis Monitoradas no Reator com Carvão Vegetal (RC) Alimentado com Meio Sintético e Etanol Sendo Adicionado em Quantidade Estequiométrica Relacionada a Concentração de Sulfato.

Tabela 5.20. Valores das Variáveis Químicas Monitoradas no Afluente dos Reatores

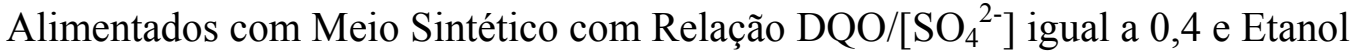
em Quantidade Correspondente ao Dobro da Estequiométrica.

Tabela 5.21. Valores das Variáveis Monitoradas no Efluente do Reator com Espuma de Poliuretano Alimentado com Meio Sintético e Etanol Sendo Adicionado em Quantidade Correspondente ao Dobro da Estequiométrica em relação a [ $\left.\mathrm{SO}_{4}{ }^{2-}\right] . .113$ Tabela 5.22. Valores das Variáveis Monitoradas no Efluente do Reator com Carvão Vegetal Alimentado com Meio Sintético e Etanol Sendo Adicionado em Quantidade Correspondente ao Dobro da Estequiométrica em relação a $\left[\mathrm{SO}_{4}{ }^{2-}\right] . .114$

Tabela 5.23. Perfil Temporal das Variáveis: CS1, CS2 e CS3 no reator com Espuma de Poliuretano Tratando Meio Sintético com Relação DQO/[SSO $\left.{ }_{4}{ }^{2-}\right]$ igual a 3,2 ... 117 Tabela 5.24. Valores das Constantes Cinéticas Calculados pelo Ajuste do Modelo Cinético aos Valores Medidos nos Perfis Temporais

Tabela 5. 25. PerfisTemporais das Variáveis: CS1, CS2, e CS3 no Reator com Espuma de Poliuretano Tratando Meio Sintético com Relação DQO/[ $\mathrm{SO}_{4}{ }^{2-}$ ]igual a 1,3

Tabela 5.26. Valores das Constantes Cinéticas Calculados pelo Ajuste do Modelo Cinético aos Valores Medidos nos Perfis Temporais 
Tabela 5.27. Perfil Temporal das Variáveis: CS1, CS2, e CS3, no Reator com Espuma de Poliuretano Tratando Meio Sintético com Relação DQO/[ $\mathrm{SO}_{4}{ }^{2-}$ ]igual a 0,4 ...... 124

Tabela 5.28. Valores das Constantes Cinéticas Calculados pelo Ajuste do Modelo aos

Valores Medidos nos Perfis Temporais 125

Tabela 5.29. Perfil Temporal das Variáveis Representadas por CS1, CS2, e CS3 no

Reator com Carvão Vegetal (RC) Tratando Meio Sintético com Relação $\mathrm{DQO} /\left[\mathrm{SO}_{4}{ }^{2-}\right]$ igual a $3,2 .$.

Tabela 5.30. Valores das Constantes Cinéticas Calculados pelo Ajuste do Modelo

Cinético aos Valores das Variáveis Representadas por CS1, CS2, e CS3, Obtidos em Perfis Temporais no Reator com Carvão Vegetal Tratando Meio Sintético com Relação DQO/[ $\left.\mathrm{SO}_{4}\right]$ igual a 3,2.

Tabela 5. 31. Perfil Temporal das Variáveis: CS1, CS2 e CS3 no Reator com Carvão

Vegetal (RC) Tratando Meio Sintético com Relação DQO/[SO $\left.{ }_{4}{ }^{2-}\right]$ igual a 1,3......129

Tabela 5.32. Valores das Constantes Cinéticas Calculados pelo Ajuste do Modelo

Cinético aos Valores Medidos nos Perfis Temporais 130

Tabela 5. 33. Perfil Temporal das Variáveis: CS1, CS2 e CS3 no Reator com Carvão

Vegetal (RC) Tratando Meio Sintético com Relação DQO/[SO $\left.{ }_{4}{ }^{2-}\right]$ igual a 0,4......131

Tabela 5.34. Valores das Constantes Cinéticas Calculados pelo Ajuste do Modelo

Cinético aos Valores Medidos nos Perfis Temporais no Reator com Carvão

Vegetal Tratando Meio Sintético com Relação DQO/[ $\left.\mathrm{SO}_{4}{ }^{2-}\right]$ igual a 0,4..... 132

Tabela 5.35. Comparação dos Parâmetros Cinéticos Determinados para o ASBBR

Contendo Espuma de Poliuretano Tratando Água Residuária Sintética com Relação DQO/[ $\left[\mathrm{SO}_{4}{ }^{2-}\right]$ igual a 3,2, 1,3, e 0,4.

Tabela 5.36. Comparação dos Parâmetros Cinéticos Determinados para o ASBBR

Contendo Carvão Vegetal Tratando Água Residuária Sintética com Relação .......136

Tabela 5.37. Perfil Temporal das Variáveis: CS1, CS2, e CS3 no Reator com Espuma

de Poliuretano Tratando Meio Sintético com Relação

Tabela 5.38. Valores das Constantes Cinéticas Calculados pelo Ajuste do Modelo Cinético aos Valores Medidos nos Perfis Temporais no Reator RE Alimentado

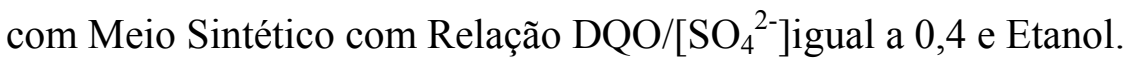


Tabela 5.39. Perfil Temporal das Variáveis: CS1, CS2 e CS3 no Reator com Carvão Vegetal Tratando Meio Sintético com Relação DQO/[ $\left.\mathrm{SO}_{4}{ }^{2-}\right]$ igual a 0,4 e Etanol.141 Tabela 5.40. Valores das Constantes Cinéticas Calculados pelo Ajuste do Modelo Cinético aos Valores Medidos nos Perfis Temporais 142

Tabela 5.41. Valores das Variáveis: $\left[\mathrm{SO}_{4}{ }^{2-}\right],[\mathrm{ST}]$ e OD nos reatores ASBBR (R1) e SBBR (R2) 143

Tabela 5.42. Porcentagem em massa dos Elementos Detectados por EDXRF nos Sólidos Retidos em Espuma de Poliuretano 


\section{LISTA DE ABREVIATURAS}

\begin{tabular}{|c|c|c|}
\hline $\mathrm{AB}$ & - Alcalinidade a Bicarbonato & $\mathrm{mg} . \mathrm{L}^{-1}$ \\
\hline $\mathrm{AM}$ & - Arqueas Metanogênicas & \\
\hline APS & - Adenosina fosfossulfato & \\
\hline ASBR & - Reator Anaeróbio de Batelada Seqüencial & \\
\hline ASBBR & - Reator Anaeróbio de Batelada Seqüencial com & \\
\hline \multirow[t]{2}{*}{ ASF } & Biomassa Imobilizada & \\
\hline & - Fatores de Adesão e Difusão & \\
\hline AT & - Alcalinidade Total & $\mathrm{mg} \cdot \mathrm{L}^{-1}$ \\
\hline ATP & -Adenosina Trifosfato & \\
\hline ATV & - Ácidos Totais Voláteis & $\mathrm{mg} \cdot \mathrm{L}^{-1}$ \\
\hline BRS & - Bactérias Redutoras de Sulfato & \\
\hline BAPH & - Bactérias Acidogênicas Produtoras de Hidrogênio & \\
\hline \multirow[t]{2}{*}{ BAP } & - Bactérias Acidogênicas Produtoras de Ácido & \\
\hline & Propiônico & \\
\hline BSA & - Bactérias Sintróficas Acetogênicas & \\
\hline $\mathrm{CE}$ & - Cerâmica Porosa Confeccionada com Alumina & \\
\hline $\mathrm{CV}$ & - Carvão Vegetal & \\
\hline $\mathrm{CDCC}$ & - Centro de Divulgação Científica e Cultural/USP & \\
\hline DAPI & 4',6-diamidino-2-fenil indol & \\
\hline DNPM & - Departamento Nacional de Pesquisa Mineral & \\
\hline DQO & - Demanda Química de Oxigênio & $\mathrm{mg} \cdot \mathrm{L}^{-1}$ \\
\hline EESC & - Escola de Engenharia de São Carlos & \\
\hline EDXRF & - Fluorescência de Raios X com Dispersão de Energia & \\
\hline FISH & - Hibridização In Situ Fluorescente & \\
\hline $\mathrm{Hac}$ & - Ácido Acético & $\mathrm{mg} \cdot \mathrm{L}^{-1}$ \\
\hline IC50 & - Concentração Inibitória de 50\% da população de uma & \\
\hline
\end{tabular}


espécie de organismo vivo

IFSC - Instituto de Física de São Carlos

LPB - Laboratório de Processos Biológicos

MEV - Microscopia Eletrônica de Varredura

MS - Material Suporte

PAPS - Fosfoadenosina Fosfossulfato

PE - Polietileno de baixa densidade reciclado

PU - Espuma de Poliuretano

RC - Reator Preenchido com Carvão Vegetal

RE - Reator Preenchido com Espuma de Poliuretano

SBR - Reator de Batelada Seqüencial

SBBR - Reator de Batelada Seqüencial com Biomassa Imobilizada

SD - Sulfeto Dissolvido

$\operatorname{mg} . \mathrm{L}^{-1}$

SRB - Sulphate Reducing Bacteria

STV - Sólidos Totais Voláteis

$\mathrm{mg} . \mathrm{L}^{-1}$

STF - Sólidos Totais Fixos

$\mathrm{mg} . \mathrm{L}^{-1}$

ST $^{*} \quad$ - Sólidos Totais

$\mathrm{mg} \cdot \mathrm{L}^{-1}$ 


\section{LISTA DE SÍMBOLOS}

W - Trabalho de adesão

$k_{1} \quad$ - Constante de equilíbrio para ionização do sulfeto de hidrogênio

$\mathrm{k}_{1 \mathrm{~A}}$ - Constante cinética de utilização de matéria orgânica adicionada, por bactérias acidogênicas

$\mathrm{k}_{1 \mathrm{~S}}$ Constante cinética de utilização de matéria orgânica adicionada, por bactérias redutoras de sulfato oxidadoras incompletas

$\mathrm{k}_{2 \mathrm{~S}}$ Constante cinética de utilização de matéria orgânica adicionada por bactérias redutoras de sulfato oxidadoras completas

$\mathrm{k}_{3 \mathrm{~S}} \quad$ Constante cinética de utilização de acetato por bactérias redutoras de sulfato

$\mathrm{k}_{3 \mathrm{M}}$ Constante cinética de utilização de acetato por arqueas metanogênicas

$\mathrm{S}_{1} \quad$ Representa a Matéria Orgânica adicionada, expressa em DQO, no modelo cinético proposto neste trabalho.

$\mathrm{S}_{2} \quad$ Representa a concentração de ácido acético expressa em DQO, no modelo cinético proposto neste trabalho $\mathrm{mg} . \mathrm{L}^{-1}$

$\mathrm{S}_{3} \quad$ Representa a concentração de sulfato no modelo cinético proposto neste trabalho

$\sigma_{a} \quad$ - Tensão na superfície de um corpo "a" N.m ${ }^{-1}$

$\sigma_{\mathrm{b}} \quad$ - Tensão na superfície de um corpo "b" N.m $\mathrm{m}^{-1}$

$\sigma_{\mathrm{ab}}$ - Tensão na interface por unidade de área de contato de dois corpos "a"e "b" 
$\sigma_{a h} \quad$ - Tensão superficial do corpo "a" a distância h do corpo "b"

$\sigma_{b h} \quad$ - Tensão superficial do corpo "b" a distância h do corpo "a"

$\sigma_{c} \quad$ - Tensão superficial crítica definida quando um líquidopadrão molha uma superfície com ângulo de contato zero

$\mathrm{mN} \cdot \mathrm{m}^{-1}$

$\sigma_{\mathrm{SV}}$ - Energia livre interfacial, na interface sólido-vapor

N.m ${ }^{-1}$

$\sigma_{\mathrm{SL}}$ - Energia livre interfacial, na interface sólido-líquido

N.m $m^{-1}$

$\sigma_{\mathrm{LV}}$ - Energia livre interfacial, na interface líquido-vapor

N.m $\mathrm{m}^{-1}$

$\theta \quad$ - Ângulo de Contato

o

$\theta_{c} \quad$ - Tempo de retenção celular

d

$\tau$ - Constante de tempo (Modelo de Crescimento Sigmoidal - Boltzman).

$\mathrm{t}_{0} \quad$ - ponto de inflexão da sigmóide no modelo de Boltzman

$t_{M} \quad$ - Tempo de mistura 


\section{RESUMO}

SILVA, A. J. (2005). Biodessulfatação com posterior oxidação parcial do sulfeto em reatores operados em bateladas seqüenciais. São Carlos, 159 p.. Tese (Doutorado) - Escola de Engenharia de São Carlos, Universidade de São Paulo.

Em reatores biológicos anaeróbios adequadamente projetados, $\mathrm{SO}_{4}{ }^{2-}$ pode ser reduzido a sulfeto pelas bactérias redutoras de sulfato (BRS), o qual, posteriormente, pode ser oxidado a enxofre elementar, em presença de baixas concentrações de oxigênio dissolvido $\left(\leq 0,1 \mathrm{mg} \cdot \mathrm{L}^{-1}\right)$. Na presente tese, o processo de biodessulfatação foi estudado em reatores anaeróbios operados em bateladas seqüenciais, com biomassa imobilizada em espuma de poliuretano (PU) e em carvão vegetal (CV), previamente selecionados por testes de adesão microbiana em reatores diferenciais. Posteriormente, avaliou-se o efeito de etanol sobre o desempenho do processo de biodessulfatação. As principais rotas de utilização de substratos orgânicos pelos microrganismos foram identificadas por meio de modelação cinética. A comunidade microbiana foi avaliada por hibridação in situ com fluorescência (FISH). Após o processo de biodessulfatação, avaliou-se o processo de oxidação parcial do sulfeto, em reator aeróbio operado em bateladas seqüenciais, com biomassa imobilizada em PU. Concluiu-se por FISH que as características intrínsecas dos materiais suportes influenciam o equilíbrio microbiano. A relação $\mathrm{DQO} /\left[\mathrm{SO}_{4}{ }^{2-}\right]$ igual a 1,3 representou a melhor condição para o processo de biodessulfatação, com PU e com CV como materiais suporte, com eficiência média em redução de sulfato igual a 96\%. A adição de etanol melhorou o processo de redução de sulfato. Sulfeto gerado no processo de biodessulfatação foi oxidado parcialmente a enxofre elementar, com eficiência de remoção de $80 \%$ no reator aeróbio.

Palavras-chave: Águas residuárias; remoção de sulfato; reatores anaeróbios; processos biológicos; oxidação de sulfeto; Título. 


\section{ABSTRACT}

SILVA, A. J. (2005). Biological sulphate removal with partial oxidation of sulfide in sequencial batch reactors. São Carlos, 182 p.. Thesis (Doctorate) - Escola de Engenharia de São Carlos, Universidade de São Paulo.

In anaerobic biological systems for wastewater treatment well-designed sulphate can be reduced to sulfide by sulphate-reducing bacteria (SRB), and it can be subsequently oxidized to elemental sulphur, under low dissolved oxygen concentration $\left(\leq 0.1 \mathrm{mg} \cdot \mathrm{L}^{-1}\right)$. The present thesis evaluates the microbial sulphate reduction process in anaerobic sequencing batch biofilm reactors with immobilized biomass in polyurethane foam (PU) and vegetable coal (CV). Such support materials were previously selected by microbial adhesion tests executed in differential reactors. Afterwards, the effect of ethanol addition on the performance of sulphate reduction process was assessed. The main metabolic pathways of organic substrate utilization by microorganisms were identified by kinectic modelation. The microbial community was evaluated by fluorescence in situ hybridization (FISH). The partial sulfide oxidation process was also evaluated in aerobic sequencing batch reactor containing biomass immobilized in PU matrices. It was concluded by FISH that characteristics of the support materials has influence on the microbial equilibrium. The $\mathrm{COD} /\left[\mathrm{SO}_{4}{ }^{2-}\right]$ ratio equal to 1.3 provided the best condition for microbial sulphate reduction process in both reactors with mean efficience of $96 \%$. The Ethanol addition improved the sulphate reducing process. The sulfide generated was partialy oxidized to elemental sulphur in the aerobic reactor with removal efficience of $80 \%$.

Keywords: Wastewater; sulphate removal; anaerobic reactors; biological process; sulphide oxidation; Title. 


\section{INTRODUÇÃO}

O enxofre elementar existe na natureza em depósitos sedimentares e como produto de sublimação vulcânica, cuja principal reserva é localizada na Sicília (Itália). Compostos de enxofre na forma de sulfatos e sulfetos metálicos estão distribuídos em várias regiões do planeta. O enxofre é um elemento essencial para os seres vivos, e muito utilizado na agricultura e indústrias químicas. O íon sulfato $\left(\mathrm{SO}_{4}{ }^{2-}\right)$ é a forma mais estável dos compostos de enxofre existentes na natureza e está presente no esgoto sanitário e em diversas águas residuárias industriais, em concentrações variáveis.

As descargas indiscriminadas diretas ou indiretas de águas residuárias contendo sulfato, em corpos receptores, podem prejudicar a qualidade das águas e também interferir no ciclo natural do enxofre.

Em sistemas de coleta e transporte de esgotos, íon sulfato pode ser reduzido a sulfeto $\left(\mathrm{S}^{2-}\right)$, sob condição de anaerobiose, pelas bactérias redutoras de sulfato (BRS). O sulfeto de hidrogênio tem odor muito desagradável, é um gás tóxico para peixes e humanos e causa corrosão em concreto e tubulações metálicas.

No corpo de água receptor, as descargas de sulfato causam aumento na salinidade, diminuindo a solubilidade do oxigênio na água. Nas zonas anaeróbias, sulfato é reduzido a sulfeto de hidrogênio, aumentando a demanda química de oxigênio (DQO). Dessa forma, o lançamento indiscriminado de sulfato num corpo de água compromete o fenômeno natural de autodepuração.

Em sistemas de tratamento biológico aeróbio de águas residuárias, sulfato eventualmente presente reduz a solubilidade do oxigênio; em sistemas anaeróbios favorece o crescimento das BRS, que competem com microrganismos acidogênicos e metanogênicos por substratos orgânicos e hidrogênio disponíveis.

Portanto, a presença de sulfato em águas residuárias deve ser considerada nos projetos de sistemas de tratamentos biológicos, aeróbios ou anaeróbios. Dessa forma, 
o controle das emissões de sulfato resultará em maior proteção da qualidade da água nos corpos receptores desses efluentes.

Considerando os problemas que sulfato pode causar se lançado indiscriminadamente no ambiente, os órgãos de controle ambiental têm exigido que as fontes emissoras reduzam as concentrações desse ânion nas águas residuárias. No Estado de São Paulo, a Lei no 997 de 31 de maio de 1976, regulamentada pelo Decreto Estadual 8468 de 1976, no Artigo 19-A, estabelece a concentração máxima de $1.000 \mathrm{mgSO}_{4}{ }^{2-} \cdot \mathrm{L}^{-1}$ em efluentes líquidos lançados direta ou indiretamente nos corpos receptores.

A redução do sulfato a sulfeto pelas BRS, em ambiente anaeróbio, e a oxidação parcial do sulfeto a enxofre elementar, em presença de baixas concentrações de oxigênio $\left(<0,1 \mathrm{mg} \cdot \mathrm{L}^{-1}\right)$, podem ocorrer em sistemas biológicos de tratamento de águas residuárias adequadamente projetados. Para isso, são importantes os conhecimentos das interações dos microrganismos envolvidos e da cinética de conversão dos substratos orgânicos e inorgânicos a produtos finais estáveis. $\mathrm{O}$ enxofre elementar $\left(\mathrm{S}^{\mathrm{o}}\right)$ pode ser recuperado e reutilizado por indústrias químicas para produzir ácido sulfúrico, ou sulfato de amônio, muito utilizado na agricultura.

Vários tipos de reatores biológicos anaeróbios foram desenvolvidos e podem ser utilizados com a finalidade de remoção de sulfato, como por exemplo: reator anaeróbio de fluxo ascendente e manta de lodo (MIZUNO et al., 1994), reator de leito granular expandido (SMUL et al, 1997), reator anaeróbio de leito fixo (SILVA, 1999).

O reator anaeróbio operado em bateladas seqüenciais (ASBR) é uma configuração recente (DAGUE et al., 1992), baseada na propriedade de floculação da biomassa, sob baixa relação entre substrato $(F)$ e microrganismos $(M)$, ou seja, baixa relação $\mathrm{F} / \mathrm{M}$, favorecendo o desenvolvimento dos processos de conversão de matéria orgânica e separação das fases sólida e líquida num único sistema. A operação desses reatores ocorre em quatro etapas: enchimento, reação, sedimentação e descarga. A etapa de sedimentação pode ser suprimida, empregando-se reatores com biomassa imobilizada em materiais suporte, conforme proposto por RATUZNEI et al. (2000). 
Reatores operados em bateladas podem ser utilizados para estudos de cinética das reações bioquímicas por suas simplicidades, pois, excluem fluxos de entrada e de saída durante a fase reacional. São facilmente adaptáveis à escala de laboratório, necessitando poucos equipamentos auxiliares ou pouca instrumentação (LEVENSPIEL, 1999). Os balanços de massa nesses reatores resultam nas próprias velocidades de reação. 


\section{OBJETIVOS}

Os principais objetivos deste trabalho foram:

a. Avaliar o processo de redução de sulfato de água residuária sintética com relações $\mathrm{DQO} /\left[\mathrm{SO}_{4}{ }^{2-}\right]$ iguais a 3,$2 ; 1,3$; e 0,4 em reatores anaeróbios contendo biomassa imobilizada em suportes inertes, operados em bateladas seqüenciais (ASBBR);

b. Identificar as principais rotas de consumo de substratos orgânicos por bactérias acidogênicas (BA), BRS e arqueas metanogênicas (AM) por meio de modelação cinética;

c. Avaliar o processo de oxidação parcial do sulfeto em reator aeróbio com biomassa imobilizada em espuma de poliuretano (PU), operado em bateladas seqüenciais (SBBR). 


\section{REVISÃO BIBLIOGRÁFICA}

\subsection{Origem do Enxofre e sua Utilização nas Atividades Antropogênicas.}

A ocorrência de enxofre na natureza dá-se nas formas elementar (depósitos sedimentares e produto de sublimação vulcânica) e combinada como sulfatos e sulfetos metálicos (Figura 3.1). As reservas mundiais de enxofre representam o enxofre associado a: gás natural, petróleo, sulfetos metálicos (cobre, chumbo, zinco, molibdênio e ferro), na forma elementar nos depósitos em rochas sedimentares deformadas, e vizinho a domos salinos nos depósitos vulcânicos, resultantes da sublimação de vapores sulfurosos de origem magmática e arenitos betuminosos. Segundo dados apurados pelo Departamento Nacional de Pesquisa Mineral (DNPM), a maior reserva mundial pertence ao Iraque $(12,4 \%)$ e a reserva brasileira representa $1,2 \%$ do enxofre existente (DNPM, 2004).

O íon sulfato é distribuído na natureza como sais dissolvidos em águas naturais, em quantidades estimadas em $1,3 \times 10^{9}$ megaton, e como sais insolúveis $5,0 \times 10^{9}$ megaton (LENS et al., 1998).

Em 2003, a produção mundial de enxofre foi de 5,9515 x $10^{7}$ t, tendo o Brasil participado com 395.000 t, o que representa 0,7 \% da produção mundial (DNPM, 2004). O Brasil importou 1.893.559 t, entre bens primários e compostos industrializados (ácido sulfúrico, enxofre sublimado, pirita, etc), e exportou $429 \mathrm{t}$ de enxofre como bens primários (por exemplo, pirita) e compostos industrializados (por exemplo, ácido sulfúrico). No Brasil, o consumo de enxofre decorre de sua aplicação na agricultura (53\% da produção), seguida pelo consumo das indústrias químicas (47\%) (diretamente relacionado à produção de ácido sulfúrico $\left(\mathrm{H}_{2} \mathrm{SO}_{4}\right)$, cujo maior destino, 70 a $80 \%$, é a produção de ácido fosfórico $\left(\mathrm{H}_{3} \mathrm{PO}_{4}\right)$ e fertilizantes). Outros importantes setores consumidores são as produções de: pigmentos inorgânicos, papel celulose, borracha, bisulfeto de carbono, explosivos, açúcar e cosméticos (DNPM, 2004). 


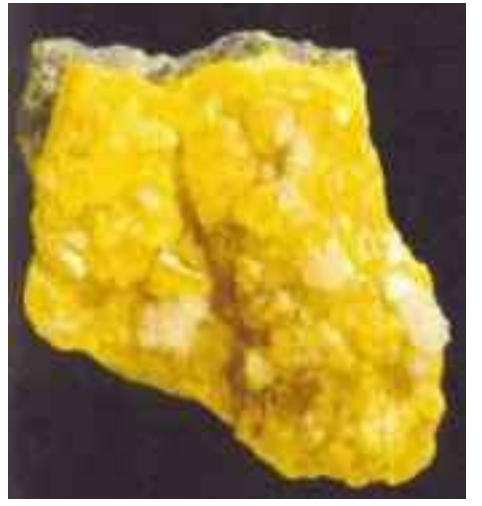

a

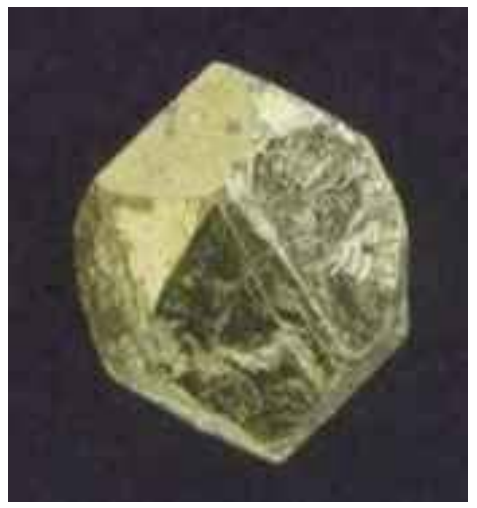

b

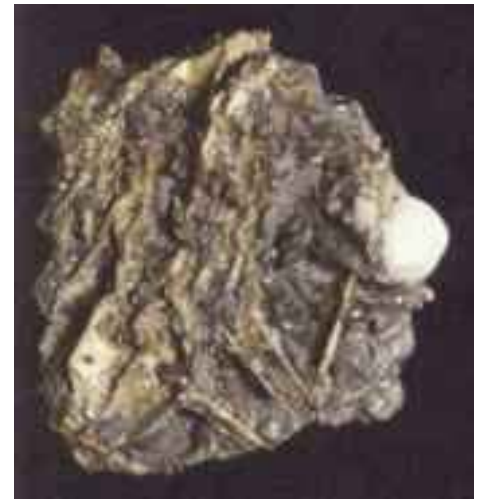

c

Figura 3.1. Formas de Enxofre Encontradas na Natureza: a. Enxofre nativo; b.

Sulfeto de ferro (pirita); c. Sulfito de ferro (pirrotita). (Fonte: CDCC/USP)

\subsection{Fontes de Emissão de Sulfato e Contaminação das Águas}

Sulfato $\left(\mathrm{SO}_{4}{ }^{2-}\right)$ é o composto de enxofre mais estável, seja nas reservas naturais ou como resíduo das atividades que utilizam enxofre. As águas naturais são contaminadas por sulfato através dos fenômenos meteorológicos e por lançamento de águas residuárias oriundas das atividades antropogênicas (Figura 3.2).

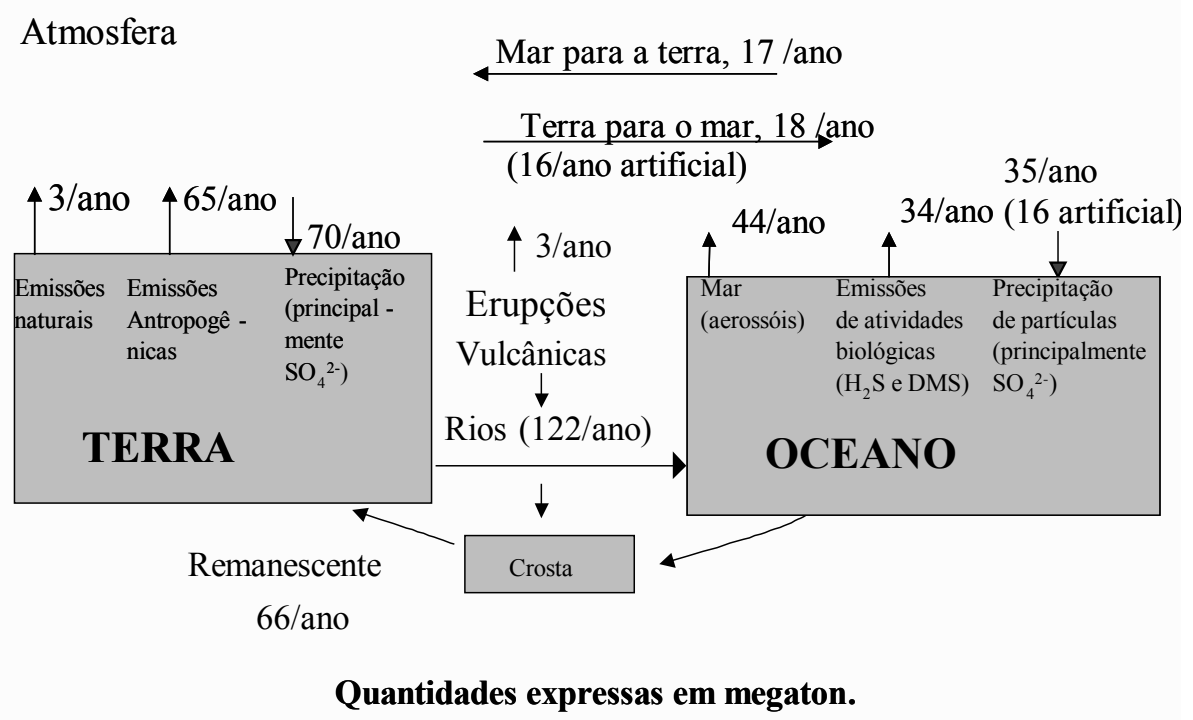

Figura 3.2. Balanço das Emissões Naturais e Antropogênicas de Enxofre (Adaptado de MADGAN et al, 1997).

LENS et al. (1998) estimam que 97 megaton de enxofre, na forma de sulfeto metálico,.são removidas anualmente do ciclo natural devido à sedimentação, na 
crosta terrestre.

\subsection{Fontes Naturais de Emissão de Sulfato}

A percolação de águas pluviais nas camadas do solo dissolve sulfatos presentes nos reservatórios sólidos, transportando-os para as águas subterrâneas e para as camadas profundas do solo, onde oxigênio pode ser escasso. Em condição anaeróbia, o íon $\mathrm{SO}_{4}{ }^{2-}$ é reduzido a sulfeto pelas BRS. Ao se combinar com íons metálicos, o íon sulfeto pode ser precipitado, constituindo as reservas de sulfetos no estado sólido. Esse fenômeno ocorre também nos oceanos.

A reoxidação do sulfeto dos estoques de precipitados ou minerais, durante a percolação de águas pluviais contendo oxigênio dissolvido, pode gerar águas ricas em sulfato, como as águas ácidas de drenagem de minas, que podem conter concentrações de $\mathrm{SO}_{4}{ }^{2-}$ moderadas $\left(0,35\right.$ a 0,55 g. $\left.\mathrm{L}^{-1}\right)$ ou altas $\left(1,5\right.$ a 7,2 g. $\left.\mathrm{L}^{-1}\right)$ (LENS et al.,1998).

Corpos de água podem conter compostos de enxofre naturalmente pela dissolução de compostos presentes na atmosfera, contaminada por aerossóis marítimos e erupções vulcânicas.

Ácido sulfúrico pode ser formado na atmosfera, em conseqüência da presença de dióxido e trióxido de enxofre. Conseqüentemente, as águas superficiais e o solo tornam-se acidificados devido às precipitações atmosféricas (chuvas ácidas) que contribuem para a diminuição da diversidade de espécies e da vitalidade de muitos ecossistemas, particularmente lagos oligotróficos fracamente tamponados.

\subsection{Emissões Antropogênicas}

Esgotos tipicamente domésticos contêm sulfato em concentrações que variam entre $20 \mathrm{mg} . \mathrm{L}^{-1}$ e $50 \mathrm{mg} . \mathrm{L}^{-1}$ (METCALF \& EDDY, 1991). Diversas águas residuárias industriais contêm concentrações de sulfato mais elevadas do que o esgoto sanitário. Além do sulfato, outros compostos de enxofre podem estar presentes. A contaminação de águas residuárias industriais com compostos de enxofre pode ocorrer devido ao uso de matérias-primas sulfurosas aplicadas aos processos, como, por exemplo, nas indústrias alimentícia e de papel e celulose, ou devido ao uso de águas contendo sulfato, por exemplo, água do mar (LENS et al, 
1998).

Em processos industriais fermentativos, as águas residuárias podem ser contaminadas por sulfato quando ácido sulfúrico for usado para controle do $\mathrm{pH}$. O uso do $\mathrm{H}_{2} \mathrm{SO}_{4}$ é estimulado por ser relativamente barato e pela possibilidade de transporte na forma concentrada (LENS et al., 1998).

Efluentes líquidos das indústrias de refino de óleos vegetais, de material fotográfico e de explosivos também contêm altas concentrações de sulfato (LENS et al., 1998).

\subsection{Fundamentos do Processo Biológico de Redução de Sulfato}

Diversos organismos, incluindo plantas superiores, algas, fungos e muitos procariontes utilizam $\mathrm{SO}_{4}{ }^{2-}$ como fonte de enxofre para a síntese celular, realizando a redução assimilativa do íon sulfato. Nesse processo, o sulfeto gerado é imediatamente convertido a enxofre orgânico na forma de aminoácidos. A redução desassimilativa do íon sulfato (Figura 3.3) é o processo através do qual sulfeto é excretado para o ambiente, ou seja, não é totalmente utilizado na síntese celular. Esse processo é realizado pelas BRS, um grupo de microrganismos amplamente distribuídos na natureza, que têm a capacidade de utilizar sulfato como aceptor de elétrons na respiração anaeróbia (MADIGAN et al., 1997).

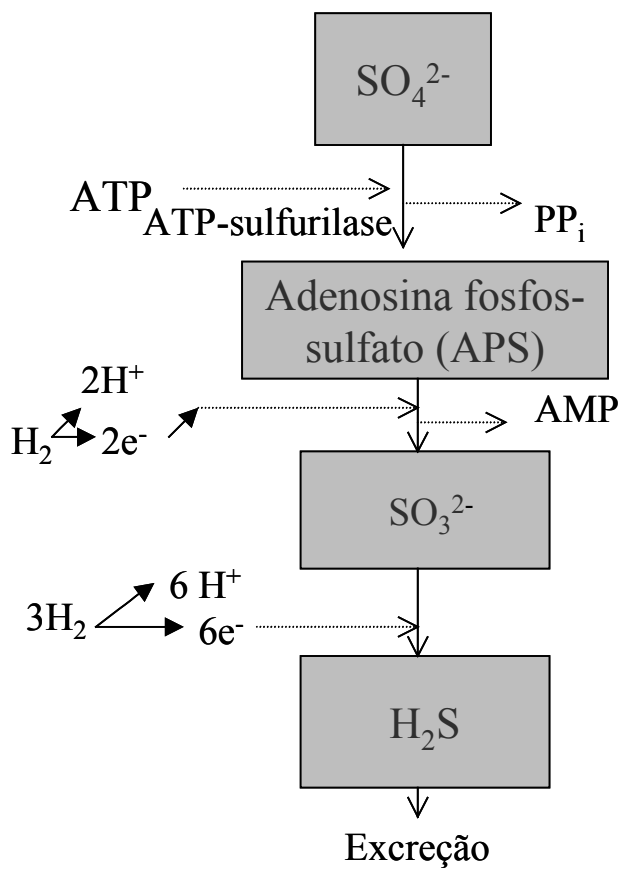

Figura 3.3. Redução Desassimilativa do Íon Sulfato (MADIGAN et al., 1997) 
$\mathrm{Na}$ Figura 3.3, $\mathrm{PP}_{\mathrm{i}}$ representa a molécula de pirofosfato que foi substituída por uma molécula de sulfato na molécula de ATP e AMP é adenosina monofosfato, resultante da redução da APS.

O processo de redução de sulfato a sulfeto ocorre através de uma seqüência de estágios intermediários resultando na transferência de oito moles de elétrons do doador (por exemplo, $\mathrm{H}_{2}$, ácidos graxos, etanol) por mol de sulfato. Um mol de oxigênio pode receber quatro moles de elétrons, o que significa que a capacidade de receber elétrons por $1 \mathrm{~mol}$ de $\mathrm{SO}_{4}{ }^{2-}$ equivale a capacidade de 2 moles de $\mathrm{O}_{2}$, ou 0,67 $\mathrm{gO}_{2}$ por $\mathrm{gSO}_{4}{ }^{2-}$. Isto significa, teoricamente, que uma determinada água residuária com relação $\mathrm{DQO} /\left[\mathrm{SO}_{4}{ }^{2-}\right]$ de 0,67 pode ter a quantidade de matéria orgânica completamente oxidada via redução de sulfato. Quando a remoção de sulfato for o objetivo do tratamento de águas residuárias que apresentem relação $\mathrm{DQO} /\left[\mathrm{SO}_{4}{ }^{2-}\right]$ menor que 0,67, carbono e elétrons devem ser introduzidos por fontes externas, como, por exemplo, etanol. Quando a relação $\mathrm{DQO} /\left[\mathrm{SO}_{4}{ }^{2-}\right]$ for superior a 0,67 , a remoção de matéria orgânica só poderá ser completa se, além da redução de sulfato, ocorrer a metanogênese (LENS et al. 1998).

O íon sulfato é bastante estável e não pode ser utilizado sem ser ativado por meio de adenosina trifosfato (ATP). A enzima ATP-sulfurilase cataliza a ligação do íon sulfato a um fosfato da molécula de ATP, formando a adenosina fosfossulfato (APS). Na redução desassimilativa (Figura 3.3), a molécula de APS é reduzida diretamente a sulfito $\left(\mathrm{SO}_{3}{ }^{2-}\right)$, mas, na redução assimilativa, outro átomo de fósforo (P) é adicionado à molécula de APS, formando fosfoadenosina fosfosulfato (PAPS) e, a partir daí, o sulfato é reduzido. Em ambos os processos de redução de sulfato, desassimilativo e assimilativo, o íon sulfito é intermediário.

$\mathrm{Na}$ ausência de um aceptor de elétrons, as BRS são capazes de crescer mediante uma reação acetogênica ou fermentativa, usando piruvato, lactato ou etanol como substratos orgânicos. Em culturas mistas, como as existentes em biorreatores para tratamento de esgotos, em presença de sulfato, as BRS competem com bactérias acidogênicas (BA) e arqueas metanogênicas (AM) hidrogenotróficas e acetoclásticas por substratos disponíveis. A importância dessa competição determina o grau de produção de metano e de sulfeto, bem como os produtos finais do processo anaeróbio de conversão da matéria orgânica (LENS et al. 1998). 
De acordo com o HOLT AND JOHN (1994), as BRS são classificadas em quatro subgrupos. O subgrupo 1 consiste de espécies pertencentes ao gênero Desulfotomaculum, que compreende todas as BRS formadoras de esporos. Microrganismos desse gênero se apresentam na forma de bacilos retos ou ligeiramente curvados, com dimensões entre $0,5 \mu \mathrm{m}$ a $2,0 \mu \mathrm{m}$ de diâmetro por $2,0 \mu \mathrm{m}$ a 9,0 $\mu \mathrm{m}$ de comprimento, freqüentemente com extremidades afiladas. Morfologias com forma de gota podem eventualmente ocorrer. Esses microrganismos formam endosporos resistentes ao calor e à dessecação, são estritamente anaeróbios, podem utilizar sulfato, tiossulfato ou sulfito como aceptores de elétrons. Muitas espécies desse gênero utilizam $\mathrm{H}_{2}$, lactato, ácidos carboxílicos $\mathrm{C}_{1}-\mathrm{C}_{18}$ e algumas utilizam açúcares ou aminoácidos. Substratos orgânicos podem ser incompletamente oxidados a acetato ou completamente oxidados a $\mathrm{CO}_{2}$. Espécies que utilizam $\mathrm{H}_{2}$ podem ser heterotróficas, requerendo acetato como fonte de carbono, ou autotróficas. Muitas espécies pertencentes ao gênero Desulfotomaculum são mais sensíveis ao $\mathrm{H}_{2} \mathrm{~S}$ produzido a partir do sulfato. $\mathrm{O} \mathrm{pH}$ ideal para crescimento situa-se entre 6,6 e 7,4 e a temperatura entre $25^{\circ} \mathrm{C}$ e $40^{\circ} \mathrm{C}$, para espécies mesofílicas, e $40^{\circ} \mathrm{C}$ e $65^{\circ} \mathrm{C}$ para espécies termofílicas.

O subgrupo 2 compreende as BRS não formadoras de esporos, que oxidam substratos orgânicos parcialmente a acetato. Esses organismos utilizam enxofre $\left(\mathrm{S}^{0}\right)$, sulfito, tiossulfato, ou sulfato como aceptor de elétrons. Os gêneros pertencentes ao subgrupo 2 são os seguintes:

- Desufobulbus: Apresentam-se como células ovais, bacilos retos, ou em forma semelhante à de limão, com dimensões de $0,6 \mu \mathrm{m}$ a $1,3 \mu \mathrm{m}$ de diâmetro por $1,5 \mu \mathrm{m}$ a 2,5 $\mu \mathrm{m}$ de comprimento, crescendo isoladamente ou em pares. Existem espécies que são movidas por um único flagelo polar e espécies imóveis. Utilizam o propionato como principal doador de elétrons, entretanto, $\mathrm{H}_{2}$, lactato, ou etanol podem ser utilizados. Os substratos orgânicos são oxidados parcialmente a acetato. $\mathrm{Na}$ ausência de aceptor externo de elétrons, lactato ou etanol e $\mathrm{CO}_{2}$ podem ser fermentados a propionato e acetato. As faixas ótimas de $\mathrm{pH}$ e de temperatura situam-se entre 6,5 a 7,5 e 25 e $40^{\circ} \mathrm{C}$, respectivamente. Habitam ambientes de água doce e sedimentos marinhos. 
- Desulfomicrobium: Espécies desse gênero têm formas ovais e de bacilos com dimensões de 0,6 $\mu \mathrm{m}$ x 1,3 $\mu \mathrm{m}$. Podem possuir um único flagelo polar para mobilidade ou serem imóveis. Doadores de elétrons podem ser $\mathrm{H}_{2}$, lactato, ou malato. Os substratos orgânicos são oxidados parcialmente a acetato. As faixas ótimas de $\mathrm{pH}$ e de temperatura estão entre 6,6-7,5 e 25 e $40^{\circ} \mathrm{C}$, respectivamente. Habitam ambientes de água doce, sedimentos marinhos, e águas oleosas, como, por exemplo, as que derivam da extração de petróleo.

- Desulfomonas: São encontradas na forma de bacilos irregulares, com dimensões entre $0,8 \mu \mathrm{m}$ a $1,3 \mu \mathrm{m}$ por $1,2 \mu \mathrm{m}$ a $5,0 \mu \mathrm{m}$ de comprimento. São imóveis e estritamente anaeróbios. Utilizam somente sulfato como aceptor, e hidrogênio, lactato, ou etanol como doadores de elétrons. Oxidam os substratos orgânicos parcialmente a acetato. As faixas ótimas de $\mathrm{pH}$ e de temperatura estão entre 6,6 e 7,5 e $30^{\circ} \mathrm{C}$ e $40^{\circ} \mathrm{C}$, respectivamente. Desulfomonas foram isoladas a partir de fezes humanas.

- Desulfovíbrio: São células com forma de espiral e vibrióide com dimensões $0,5 \mu \mathrm{m}$ a $1,3 \mu \mathrm{m}$ de diâmetro por $0,8 \mu \mathrm{m}$ a $5,0 \mu \mathrm{m}$ de comprimento, movidas por um único flagelo ou tufo de flagelos polar com exceção de Desulfovíbrio carbinolicus, que é imóvel. As espécies desse gênero são estritamente anaeróbias e reduzem sulfato, tiossulfato, sulfito, e enxofre elementar a $\mathrm{H}_{2} \mathrm{~S}$. Hidrogênio, lactato, etanol, malato ou fumarato servem como doadores de elétrons; algumas espécies podem utilizar açúcar, glicerol, colina, ou aminoácidos. Oxidam parcialmente os substratos orgânicos a acetato. As faixas ótimas de $\mathrm{pH}$ ficam entre 6,6 e 7,5 e de temperatura, entre $25^{\circ} \mathrm{C}$ e $40^{\circ} \mathrm{C}$. Habitam ambientes de água doce, sedimentos marinhos, águas oleosas, efluentes industriais e intestinos de animais.

- Thermodesulfobacterium: São células ovaladas e em forma de bacilos com dimensões $0,3 \mu \mathrm{m}$ de diâmetro por $0,9 \mu \mathrm{m}$ a $2,5 \mu \mathrm{m}$ de comprimento. Algumas espécies são movidas por um flagelo polar, outras são imóveis. São estritamente anaeróbias e utilizam sulfato como aceptor, e $\mathrm{H}_{2}$ ou lactato como doadores de elétrons. Substratos orgânicos são parcialmente oxidados a acetato. São faixas ótimas de $\mathrm{pH}$ : 6,6-7,5 e de temperatura entre $65^{\circ} \mathrm{C}-70^{\circ} \mathrm{C}$. 
Espécies de Termodesulfobacterium foram isoladas de fontes de águas quentes e águas oleosas.

O subgrupo 3 compreende as BRS não formadoras de esporos que oxidam substratos orgânicos completamente a $\mathrm{CO}_{2}$. Também fazem parte desse subgrupo as arqueas redutoras de sulfato, termofílicas, que oxidam completamente substratos orgânicos.

- Desulfobacter: São células ovais, com forma de bacilos, ou ligeiramente curvadas, com dimensões $0,5 \mu \mathrm{m}$ a $2,5 \mu \mathrm{m}$ por $1,7 \mu \mathrm{m}$ a $7,0 \mu \mathrm{m}$ de comprimento, movidas por um flagelo polar. Existem algumas espécies imóveis. Reduzem sulfato, tiossulfato e sulfito a $\mathrm{H}_{2} \mathrm{~S}$. $\mathrm{O}$ acetato é o doador de elétrons preferido. Além de acetato, algumas espécies utilizam etanol, hidrogênio e lactato. Desulfobacter hydrogenophilus cresce autotroficamente utilizando $\mathrm{CO}_{2}$ como única fonte de carbono. Adições de $\mathrm{NaCl}\left(7\right.$ g.L $\left.\mathrm{L}^{-1}\right)$ e $\mathrm{MgCl}_{2} \cdot 6 \mathrm{H}_{2} \mathrm{O}\left(>1 \mathrm{~g} . \mathrm{L}^{-1}\right)$, geralmente, têm efeito estimulante, sendo, às vezes, necessárias para o crescimento desses microrganismos. São faixas ótimas de pH: de $6,5-7,4$ e de temperatura, entre $20^{\circ} \mathrm{C}$ e $33^{\circ} \mathrm{C}$. A presença de espécies do gênero Desulfobacter ocorre em sedimentos marinhos ou salobros. Esses organismos podem ocorrer em águas doces e oleosas.

- Desulfobacterium: São células ovais, bacilos retos ou ligeiramente curvados e vibrióides, com dimensões de 0,7 $\mu \mathrm{m}-3,0 \mu \mathrm{m}$ x 1,5 $\mu \mathrm{m}-2,8 \mu \mathrm{m}$. Existem espécies que são movidas por meio de um flagelo polar e outras imóveis. Reduzem sulfato, tiossulfato, e sulfito a $\mathrm{H}_{2} \mathrm{~S}$. Nutricionalmente, as espécies de Desulfobacterium são muito versáteis. Muitas espécies utilizam $\mathrm{H}_{2}$, formiato e ácidos carboxílicos até $\mathrm{C}_{16}$, lactato, ou etanol, como doadores de elétrons. Várias espécies podem utilizar compostos aromáticos, tais como, ácidos orgânicos com grupo fenil, compostos fenólicos, ou compostos Nheterocíclicos. Apresentam baixo crescimento em acetato ou propionato. Espécies que utilizam $\mathrm{H}_{2}$ são autotróficas. São faixas ótimas de $\mathrm{pH}$ : 6,6-7,6 e de temperatura geralmente está entre 20 e $30^{\circ} \mathrm{C}$, e raramente, entre $30^{\circ} \mathrm{C}$ e $35^{\circ} \mathrm{C}$. Espécies desse gênero são comuns em sedimentos de água doce, marinhos e salobros.

- Desulfococcus: São células esféricas ou ovaladas, com dimensões entre 1,4

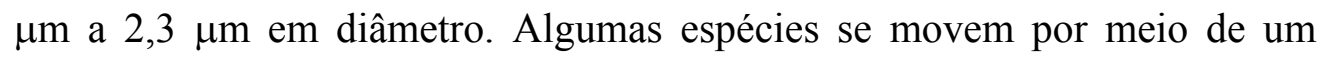


flagelo polar e outras são imóveis. São estritamente anaeróbias e nutricionalmente versáteis. Muitas espécies utilizam formiato e ácidos carboxílicos até $\mathrm{C}_{16}$, lactato ou etanol como doadores de elétrons. Acetona, ácidos orgânicos com grupo fenil, ou nicotinato podem ser utilizados. São faixas ótimas de $\mathrm{pH}: 6,7-7,6$ e de temperatura entre $28^{\circ} \mathrm{C}$ e $35^{\circ} \mathrm{C}$. Espécies desse gênero são encontradas em águas doces, sedimentos salobros e marinhos.

- Desulfomonile: São células em forma de bacilos com dimensões $0,8 \mu \mathrm{m}-1,0$ $\mu \mathrm{m} \times 5,0 \mu \mathrm{m}-10,0 \mu \mathrm{m}$, com extremidades arredondadas, imóveis e estritamente anaeróbias. Reduzem sulfato, tiossulfato e sulfito a $\mathrm{H}_{2} \mathrm{~S}$. Crescem melhor utilizando piruvato, porém, $\mathrm{H}_{2}$, formiato, ou benzoato também são utilizados. Essas espécies têm crescimento mais pobre quando utiliza lactato, acetato, ou butirato. A faixa ótima de $\mathrm{pH}$ é 6,8-7,0 e a temperatura ótima é $37^{\circ} \mathrm{C}$. Desulfomonile foi isolado a partir de lodo de esgoto. Esses microrganismos são capazes de realizar a desalogenação redutiva do 3-clorobenzoato, convertendo-o em benzeno.

- Desulfonema: São células arranjadas em filamentos com dimensões 2,5 $\mu \mathrm{m}$ $8,0 \mu \mathrm{m}$ em diâmetro, podem ter comprimento de até $2 \mathrm{~mm}$. Esses organismos se movem por deslizamento. Espécies desse gênero são estritamente anaeróbias e podem reduzir sulfato, tiossulfato e sulfito, a $\mathrm{H}_{2} \mathrm{~S}$. Enxofre exerce efeito inibitório sobre esses microrganismos. Os doadores de elétrons são : acetato, ácidos carboxílicos até $\mathrm{C}_{16}$, fumarato, e succinato. Opcionalmente, utilizam $\mathrm{H}_{2}$, lactato, ou benzoato. São faixas ótimas de $\mathrm{pH}$ : 7,0-7,6 e de temperatura, entre $28^{\circ} \mathrm{C}$ e $32^{\circ} \mathrm{C}$. Espécies desse gênero ocorrem em ambientes ricos em compostos orgânicos e em sedimentos marinhos.

- Desulfosarcina: São células em forma de bacilos, ovais, ou quase cocóides, com dimensões $1 \mu \mathrm{m}$ a $1,5 \mu \mathrm{m}$ de diâmetro por $1,5 \mu \mathrm{m}$ a $2,5 \mu \mathrm{m}$ de comprimento. Crescem em arranjos em forma de sarcina e aderidas a superfícies. Células isoladas podem se mover por um flagelo polar. Esses organismos são estritamente anaeróbios, reduzem sulfato, tiossulfato, ou sulfito a $\mathrm{H}_{2} \mathrm{~S}$. Hidrogênio, formiato e ácidos carboxílicos até $\mathrm{C}_{16}$, lactato, etanol, fumarato, e benzoato servem como doadores de elétrons. $\mathrm{O}$ 
crescimento utilizando acetato é reduzido. São capazes de crescer autotroficamente. A faixa ótima de $\mathrm{pH}$ é 7,2-7,6 e a temperatura ótima é $33^{\circ} \mathrm{C}$. Espécies desse gênero são comuns em sedimentos marinhos.

O subgrupo 4 é constituído por bactérias que reduzem enxofre a $\mathrm{H}_{2} \mathrm{~S}$.

- Desulfurella: São bacilos retos e ovais, algumas vezes curvados, com dimensões $0,4 \mu \mathrm{m}$ a $0,8 \mu \mathrm{m}$ de diâmetro por $1,0 \mu \mathrm{m}$ a 4,0 $\mu \mathrm{m}$ de comprimento que se movem por meio de um flagelo lateral. São estritamente anaeróbios e reduzem enxofre a $\mathrm{H}_{2} \mathrm{~S}$. Não reduzem oxiânions do enxofre. Acetato serve como doador de elétrons e é oxidado completamente a $\mathrm{CO}_{2}$. A faixa ótima de $\mathrm{pH}$ fica entre 6,8-7,0. São moderadamente termofílicos, com crescimento ótimo a temperaturas entre $52^{\circ} \mathrm{C}$ e $57^{\circ} \mathrm{C}$. Habitam fontes geotérmicas ricas em compostos orgânicos

- Desulfuromonas: São células em formas de bacilos e ovais, algumas vezes curvadas, com dimensões $0,4 \mu \mathrm{m}$ a $0,8 \mu \mathrm{m}$ de diâmetro por $1,0 \mu \mathrm{m}$ a 4,0 $\mu \mathrm{m}$ de comprimento que se movem pela ação de um flagelo lateral. São estritamente anaeróbios e reduzem somente enxofre a $\mathrm{H}_{2} \mathrm{~S}$. Utilizam acetato, propionato e etanol, como doadores de elétrons, oxidando-os completamente a $\mathrm{CO}_{2}$. A faixa ótima de $\mathrm{pH}$ está entre 6,8-7,5 e a temperatura ótima é cerca de $30^{\circ} \mathrm{C}$. Habitam sedimentos marinhos.

A atividade das BRS pode estimular a degradação de propionato, pelo fato das reações serem independentes da pressão parcial de hidrogênio (HARADA et al., 1994), ao passo que a adição de propionato pode também melhorar a redução de sulfato (LENS et al. 1998). HARADA et al. (1994) concluíram que as BRS desempenham papel importante na oxidação do propionato para acetato, após observarem acúmulo de propionato em meio contendo lodo anaeróbio retirado após 180 dias de um reator alimentado com esgoto sintético. Os autores observaram que, a altas concentrações de sulfato, não ocorreu acúmulo de propionato. MIZUNO et al. (1994), estudando o efeito da relação $\mathrm{DQO} /\left[\mathrm{SO}_{4}{ }^{2-}\right]$ na degradação do butirato, verificaram que, em presença de sulfato, as BRS podem competir com vantagem pelo butirato com as bactérias sintróficas acetogênicas produtoras de hidrogênio (BAPH). 


\subsection{Processos Biológicos de Remoção de Oxiânions de Enxofre com Oxidação Parcial de Sulfeto}

Nas últimas décadas, várias alternativas biotecnológicas têm sido desenvolvidas para a remoção de oxiânions de enxofre $\left(\mathrm{SO}_{3}{ }^{2-}, \mathrm{HSO}_{3}{ }^{-}, \mathrm{S}_{2} \mathrm{O}_{3}{ }^{2-}, \mathrm{SO}_{4}{ }^{2-}\right.$, entre outros) principalmente de efluentes líquidos industriais. Inicialmente, os óxidos de enxofre são transformados em sulfeto em ambiente anaeróbio. Sulfeto é subseqüentemente re-oxidado para enxofre elementar $\left(\mathrm{S}^{0}\right)$, que pode ser recuperado. Nesse processo biotecnológico, pode ser utilizado Thiobacillii sp. (SMUL et al., 1997). A oxidação biológica parcial de sulfeto é considerada uma alternativa de baixo custo para a recuperação de enxofre elementar, quando comparado aos processos físicos e químicos existentes (LENS et al., 1998). Esse processo pode ocorrer em ambientes aeróbios, anóxicos e anaeróbios. Sob essas condições, respectivamente, oxigênio, nitrato ou $\mathrm{CO}_{2}$ são utilizados como aceptores de elétrons. Desse processo participam bactérias fototróficas anoxigênicas e bactérias quimiolitotróficas.

De acordo com HOLT AND JOHN (1994), bactérias fototróficas anoxigênicas (BFA) dividem-se em sete subgrupos. Esses organismos encontram-se como células esféricas, espiraladas, bacilos retos ou em forma de víbrios, com dimensões $0,3 \mu \mathrm{m}-6,0 \mu \mathrm{m}$. Ocorrem isoladamente e em agregados regular ou irregular e podem formar filamentos. Existem espécies que se movimentam por flagelo ou deslizamento, e espécies imóveis. As cores das suspensões de células variam a partir de violeta-púrpura a vermelho-púrpuro, vermelho rosado, marrom amarelado, marrom, e verde. Todas as espécies contêm pigmentos de bacterioclorofila e carotenóides e são fotoautotróficas ou fotoheterotróficas sob condições anaeróbias ou microaeróbias. Compostos reduzidos de enxofre são utilizados como doadores externos de elétrons, assim como, $\mathrm{H}_{2}$ ou compostos orgânicos. Durante a oxidação do sulfeto, glóbulos de enxofre são armazenados pelas células, internamente (subgrupo 1) e externamente (subgrupos 2 e 5), além de polissacarídeos, poli- $\beta$-hidroxibutirato, e polifosfato. Esses microrganismos assimilam $\mathrm{CO}_{2}$ e utilizam, geralmente, sais de amônia como fontes de nitrogênio. Com exceção das espécies pertencentes ao subgrupo 6 , as demais são capazes de 
assimilar $\mathrm{N}_{2}$. Muitas espécies, exceto as pertencentes ao subgrupo 5, crescem quimioautotroficamente ou quimiorganotroficamente sob condições anaeróbia e microaeróbia. Ácidos graxos, outros ácidos orgânicos, ou álcoois servem como doadores de elétrons e fontes de carbono. BFA habitam solos úmidos e ambientes aquáticos incluindo águas doces, salobras e marinhas, além de ambientes hipersalinos.

O subgrupo 1 é constituído por BFA que armazenam glóbulos de enxofre dentro das células e o oxidam posteriormente a sulfato. Ao subgrupo 2 das BFA pertencem os microrganismos que podem, além do sulfeto, utilizar enxofre elementar como doador de elétrons na assimilação de $\mathrm{CO}_{2}$. Glóbulos de enxofre são depositados fora das células e podem, posteriormente, ser oxidados a sulfato. O crescimento depende da salinidade e da alcalinidade. O subgrupo 3 das BFA compreende microrganismos que foto-assimilam substâncias orgânicas simples, sendo que algumas espécies são capazes de utilizar tiossulfato como doadores de elétrons para assimilar $\mathrm{CO}_{2}$. Depositam glóbulos de enxofre fora da célula que são, raramente, oxidados a sulfato. Muitos gêneros são quimioheterotróficos sob condição microaeróbia ou aeróbia. O subgrupo 4 de BFA é constituído por microrganismos que foto-assimilam compostos orgânicos simples, são estritamente anaeróbios e fotoheterotróficos. Esses microrganismos não utilizam sulfeto. $O$ subgrupo 5 compreende as BFA que utilizam sulfeto ou enxofre como doador de elétrons para a assimilação de $\mathrm{CO}_{2}$. Depositam glóbulos de enxofre fora da célula. Todas as espécies são anaeróbias e fototróficas obrigatórias. Assimilam compostos orgânicos, na presença de sulfeto e bicarbonato. As suspensões de células são verdes ou marrons. As BFA pertencentes ao subgrupo 6 formam filamentos multicelulares arranjados em seqüência única, e se movem por deslizamento. Todos os gêneros são facultativamente aeróbios e, preferencialmente, utilizam substâncias orgânicas em seu metabolismo fototrófico ou quimiotrófico. Finalmente, o subgrupo 7 é constituído por células que crescem quimiolitotróficamente sob condições aeróbias. Os organismos desse subgrupo não crescem em condição anaeróbia, em presença de luz, e o metabolismo é predominantemente respiratório.

FUTIWAKI et al. (2004) observaram remoção de 99\% de sulfeto, utilizando a sulfubactéria púrpura Cromatium vinosum DSM 183, aplicando concentrações de 
sulfeto entre 9,3 mg. $\mathrm{L}^{-1}$ e $334 \mathrm{mg} . \mathrm{L}^{-1}$. Esses autores observaram que, após a utilização do sulfeto, Cromatium vinosum DSM 183 passou a utilizar enxofre elementar, armazenado intracelularmente, como doador de elétrons e que a maior parte do consumo de sulfeto foi direcionada para o crescimento celular. Por exemplo, com concentrações iniciais de sulfeto de $188 \mathrm{mg} . \mathrm{L}^{-1}$ a $334 \mathrm{mg} . \mathrm{L}^{-1}$, menos de $30 \%$ do sulfeto foi convertido a enxofre elementar, mas a eficiência em remoção desse ânion foi superior a $99 \%$.

\subsection{Reatores Utilizados para o Tratamento Biológico Anaeróbio de Águas Residuárias Contendo Sulfato.}

Segundo CAMPOS (1990), a partir de 1970 a aplicação de processos anaeróbios no tratamento de águas residuárias foi valorizada. Houve aumento significativo das alternativas de concepções físicas das unidades de conversão biológica.

Os principais reatores utilizados em sistemas anaeróbios são compostos por meios físicos de adesão ou utilizam microrganismos auto-imobilizados na forma de grânulos. Os reatores anaeróbios com biomassa imobilizada têm ampla aplicação no tratamento de águas residuárias. A principal vantagem desses reatores é a possibilidade de se trabalhar com alto tempo de retenção celular em relação ao tempo de detenção hidráulica. Nesses reatores, microrganismos são retidos nos interstícios existentes em leito constituído por materiais inertes como, por exemplo, pedras, PVC, carvão ativado, espuma de poliuretano, polietileno, cerâmicas. Além de ocupar os interstícios, microrganismos crescem sobre a superfície desses materiais, formando biofilmes. Assim, forma-se uma região com alta concentração de microrganismos ativos no reator, obrigatoriamente atravessada pela água residuária em tratamento, em fluxo ascendente ou descendente.

Além do crescimento aderido em materiais suporte, pode ocorrer a autoimobilização na forma de grânulos. Essa propriedade é explorada nos reatores anaeróbios de fluxo ascendente e manta de lodo (UASB - upflow anaerobic sludge blanket), amplamente empregados no tratamento de águas residuárias industriais, como por exemplo, abatedouro de aves, cervejarias e laticínios, e também no tratamento de esgoto sanitário. 
Os reatores que utilizam materiais inertes para imobilização de microrganismos podem ser classificados em reatores de leito fixo e reatores de leito móvel, como por exemplo, os reatores de leito expandido e de leito fluidificado (CAMPOS, 1990).

Segundo (ZAIAT et al., 2001), a utilização de reatores contendo células imobilizadas em suporte inerte apresenta a vantagem de se eliminar as incertezas referentes à granulação do lodo. No entanto, devem ser empregados suportes adequados, que permitam boa adesão dos microrganismos envolvidos e que tenham custo acessível. Esta escolha deve ser criteriosa, baseada em ensaios de aderência celular e contemplando o aspecto econômico.

A maioria das configurações de reatores anaeróbios de altas taxas, utilizada para tratamento de águas residuária, pode ser empregada em processos que visam a remoção de compostos de enxofre. ISA et al. (1986a e 1986b) observaram a ocorrência simultânea dos processos sulfetogênico e metanogênico em reatores anaeróbios com biomassa imobilizada em espuma de poliuretano. SMUL et al. (1997) observaram altas taxas de redução microbiana de sulfato em reator com leito granular expandido (EGSB - expanded granular sludge bed). LENS et al. (2000) utilizaram um reator anaeróbio compartimentado com atividades sulfetogênica e metanogênica para avaliar o efeito da adição de nitrato, visando a otimização dos dois processos. SILVA et al. (2002) observaram a viabilidade de redução de sulfato em água residuária industrial utilizando reator anaeróbio de leito fixo com fluxo horizontal. Esses autores constataram que etanol pode estimular o processo sulfetogênico no tratamento de águas residuárias que requerem a adição de fonte de carbono e doador de elétrons externos.

PEREZ-RODRIGUEZ et al. (1989) estudaram o efeito de algumas argilas minerais utilizadas como suporte de imobilização para o crescimento de BRS em reatores anaeróbios. Esses autores testaram sepiolita natural, sepiolita tratada (para garantir melhor dispersão do material), montimorilonita e vermiculita e compararam esses materiais com poliuretano expandido e PVC. Os autores concluíram que a espuma de poliuretano foi o suporte no qual as BRS cresceram em maior quantidade, seguida pelo PVC e montimorilonita. Segundo os autores, a dificuldade de crescimento de BRS sobre a sepiolita tratada foi, possivelmente, devido a adsorção 
de alguns componentes necessários para o crescimento dessas bactérias nos canais do mineral, tornando-os inacessíveis.

Outra configuração, o reator anaeróbio operado em bateladas seqüenciais (ASBR) foi desenvolvido com base nos princípios de que a biomassa anaeróbia floculava de maneira análoga ao processo aeróbio de lodos ativados (DAGUE et al., 1992). Esses autores observaram que a eficiência da floculação era afetada pela carga orgânica, particularmente pela relação alimento (F)/microrganismos (M). Os melhores resultados quanto a retenção de biomassa e estabilidade em remoção de DQO foram obtidos com relação F/M igual a 0,5. A operação do ASBR (Figura 3.4) é muito simples e ocorre em quatro estágios: enchimento, reação, sedimentação e descarga, que constituem um ciclo.

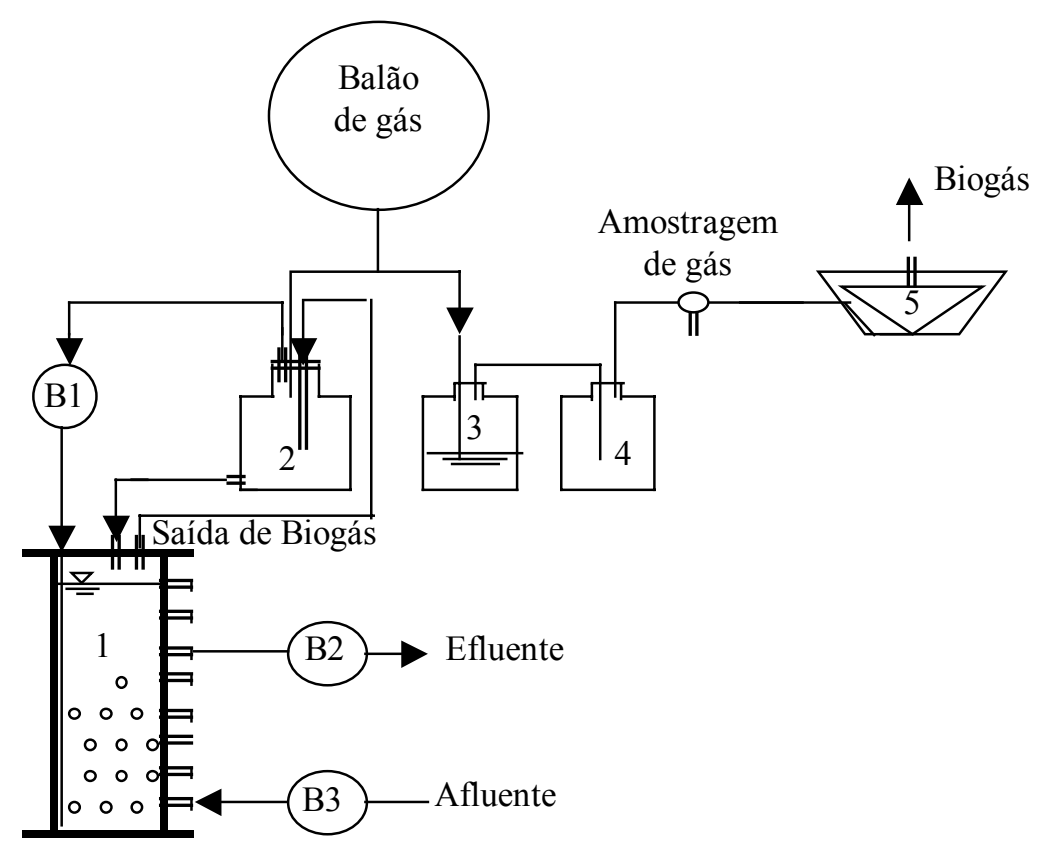

Figura 3.4. Esquema de Operação do ASBR com Recirculação do Biogás. (1) Reator, (2) Aspiração do Biogás, (3) Frasco p/ observação (4) Absorção de $\mathrm{H}_{2} \mathrm{~S}$, (5) Medidor de Biogás. B1, B2 e B3, correspondem aos bombeamentos de gás, efluente e afluente, respectivamente (Adaptado de Zaiat et al., 2001).

Essa configuração de reator tem sido estudada para aplicação no tratamento de diversas águas residuárias, tais como: resíduos de suinocultura (SCHMIT \& DAGUE, 1993); chorume (TIMUR \& ÖSTURK, 1999); laticínios (DUGBA \& ZHANG, 1999). 
O bom desempenho do ASBR está relacionado ao fenômeno de granulação. O período de partida requerido para a formação do grânulo pode ser longo, de pelo menos cinco meses. Esse período pode ser reduzido para três a quatro meses adicionando-se substâncias para melhorar a granulação, como carvão ativado em pó e granular, areia de sílica, polímeros e cloreto férrico (WIRTZ \& DAGUE, 1997).

A operação do ASBR em regime intermitente possibilita controlar a duração do ciclo de modo a se obter a qualidade desejada para o efluente tratado, ou seja, o lançamento no corpo receptor em conformidade com os padrões de emissão estabelecidos. Entretanto, há fatores que afetam o desempenho desse tipo de reator, sendo os principais: agitação, relação inicial entre substrato e biomassa, configuração geométrica e estratégia de alimentação. A imobilização dos microrganismos em suportes inertes é uma alternativa promissora pelo fato de melhorar a retenção de biomassa e suprimir a etapa de sedimentação (ZAIAT et al., 2001). Nesse sentido, RATUSZNEI et al. (2000) propuseram e testaram o reator anaeróbio operado em batelada seqüencial contendo biomassa imobilizada em suporte inerte e obtiveram bons resultados no tratamento de água residuária de baixa carga, eficiência média de remoção de DQO igual a $86 \%$, permitindo a supressão da etapa de sedimentação da biomassa e reduzindo, conseqüentemente, o tempo total do ciclo.

\subsection{Fundamentos da Adesão Microbiana em Superfícies de Materiais Inertes}

As interações entre partículas e superfícies são importantes para muitas aplicações tecnológicas, bem como em sistemas biológicos. Apesar da ampla aplicação em processos industriais, no campo da saúde e alimentos, ainda não existe uma teoria quantitativa para descrever a adesão em todos os aspectos, devido a diversos fatores como: falta de conhecimento sobre as forças de adesão entre dois corpos e ocorrência de ligações químicas e não químicas fora da interface ou na superfície. As forças de adesão podem ser estimadas a partir de um modelo cinético relativamente simples, que considera a adesão entre pequenas partículas esféricas e um substrato sólido liso. Sistemas desse tipo são denominados "ideais" e somente são válidos quando forças atrativas de longo alcance entre o aderente e a superfície, como forças de van der Waals e forças eletrostáticas, são aplicáveis. A força atrativa entre uma esfera e a superfície plana gera deformação da interface comum (uma 
parte elástica e outra não elástica), de modo que uma área de contato denominada "área adesiva" é formada, a qual pode aumentar com o passar do tempo, dependendo da rigidez da superfície. O modelo de interação "esfera-superfície plana" é inadequado para o estado de adesão "real" porque partículas e substratos reais não são lisos, sendo a zona de contato constituída de vários pontos onde as forças de pequeno alcance são mais fortes e, portanto, a adesão é suscetível à geometria detalhada dos corpos próximos aos pontos de contato. O sistema exige uma extensa faixa de forças adesivas para que a população seja entendida como uniforme. As células de animais superiores sofrem deformações plásticas nos pontos de contato devido às grandes pressões que agem sobre elas, mas as bactérias são mais rígidas e parecem não deformar quando interagem com superfícies. A natureza complexa da superfície celular possibilita vários tipos de interações simultaneamente, como interações hidrofóbicas e hidrofílicas, pontes de hidrogênio, ligações eletrostáticas, etc. Todavia, teorias quantitativas que descrevem todas essas interações são escassas (PETHICA, 2000).

Segundo PETHICA (2000), a produção de moléculas complexas por microrganismos conduz à formação da camada condicionante, que é importante no processo de fixação microbiana a suportes. É importante diferenciar adesão de deposição. Adesão é governada por forças de pequeno alcance e é mais complexa do que a deposição, que é governada por forças de longo alcance.

Em processos de adesão, as forças de pequeno alcance são responsáveis pela formação da ligação primária, covalente e iônica, através de fortes interações com a superfície. Interações de energia intermediária, como pontes de hidrogênio, ligações de transferência de cargas eletrônicas, forças da dupla camada eletrônica e forças relacionadas com reações interfaciais também devem ser consideradas. Interações relativamente fracas, associadas com a formação da camada secundária também ocorrem. As forças envolvidas na adesão de partículas são divididas em três classes: interações atrativas de longo alcance, forças de curto alcance e reações interfaciais, (PETHICA, 2000).

\subsection{Adesão Microbiana}

Muitos microrganismos não se dividem se não estiverem em contato com 
superfícies. Em superfícies inertes, as reações bioquímicas microbianas são dependentes da maneira de contato dos microrganismos. As células variam o modo de contato de maneira interativa. Após o contato inicial, estruturas celulares podem ser formadas e as membranas das células podem ser modificadas de diversas formas, por exemplo, aumentando a permeabilidade para permitir trocas químicas. A adesão celular num suporte sólido pode ser modificada devido à presença de proteínas no meio de cultura ou pela produção de substâncias extracelulares por determinadas espécies microbianas, as quais podem condicionar a superfície de adesão. Algumas proteínas competem, pela superfície com substâncias denominadas fatores de adesão e difusão (ASF), e dificultam a adesão (PETHICA, 2000).

A teoria atual sobre biocontato é explicada por meio da teoria de estabilidade dos colóides ou abrange uma ampla consideração fenomenológica em termos de energias superficiais. Isso envolve cálculos complexos para a determinação da energia de aproximação de uma célula a uma superfície de contato. A tensão superficial de uma célula ou de uma superfície de contato pode ser aproximada pelo uso dos ângulos de contato acoplados com a termodinâmica. Num sistema constituído por duas células ou uma célula e um sólido inerte, a energia livre total é reduzida pelo contato, de modo que a adesão ocorre segundo uma taxa controlada por determinadas barreiras que podem estar presentes (PETHICA, 2000).

Segundo PHETICA (2000), o conceito de molhabilidade considera a redução de energia livre total como resultado da diminuição da energia livre interfacial, identificada com a tensão superficial das membranas celulares. O trabalho de adesão $(W)$ por unidade de área de contato é calculado como mostrado nas equações $3.1 \mathrm{e}$ 3.2 .

$$
\begin{aligned}
& W=\sigma_{a b}-\sigma_{a}-\sigma_{b} \\
& \sigma_{a b}=\sigma_{a h}+\sigma_{b h}
\end{aligned}
$$

Nas expressões 3.1 e $3.2, \sigma_{a b}$ é a energia livre interfacial total por unidade de área de contato entre duas superfícies; a e b, separadas por uma distância $(h)$, composta pelas contribuições $\sigma_{\mathrm{ah}} \mathrm{e} \sigma_{\mathrm{bh}}$ das superfícies opostas, sendo $\sigma_{\mathrm{a}}$ e $\sigma_{\mathrm{b}}$ as energias livres interfaciais ou tensões superficiais das duas superfícies distantes.

Esse conceito é útil por possibilitar a aplicação de procedimentos experimentais adequados para quantificar as mudanças nas tensões superficiais. $O$ 
procedimento mais proveitoso é a comparação de ângulos de contato entre modelos líquidos e a superfícies de culturas de células. Esses ângulos de contato são usados para obter a tensão de molhabilidade crítica $\left(\sigma_{c}\right)$ para várias superfícies. Essa tensão é, na prática, a tensão de um líquido hipotético que apenas deveria molhar a superfície-teste com ângulo de contato zero (PETHICA, 2000).

A interpretação de ângulos de contato e cálculos de trabalho de adesão de líquidos a sólido utilizando a equação de Young são extensivamente abordados na literatura (ADANSON, 1990).

Uma gota macroscópica de líquido em contato com um sólido liso, homogêneo, isotrópico, rígido e insolúvel, em equilíbrio com a fase vapor na presença ou ausência de um campo gravitacional, exibirá um ângulo de contato $(\theta)$ governado pela equação 3.3 (equação de Young) : (ADANSON, 1990).

$\sigma_{S V}=\sigma_{S L}+\sigma_{L V} \cos \theta$

$\mathrm{Na}$ Equação 3.3, os subscritos referem-se às interfaces líquido/vapor (LV), sólido/vapor (SV) e sólido/líquido (SL). Relações similares se aplicam a gotas em contato com superfícies sólidas sob um segundo líquido. A equação de Young é particularmente utilizada para obtenção do trabalho de adesão de um líquido a um sólido, desde que as diferenças das tensões superficiais desconhecidas nas interfaces sólidas (SV e SL) possam ser eliminadas, resultando na equação 3.4.

$W=\sigma_{L V}(1+\cos \theta)$

Esse conceito tem demonstrado ser útil no estudo da molhabilidade de polímeros de interesse biológico. Existem dúvidas, em muitos casos, sobre o valor de equilíbrio de $\theta$, porque o ângulo de contato é diferente para avanço e retrocesso do menisco e porque a baixa rigidez de alguns sólidos implica em deformação plástica na gota. Para sistemas biológicos, a aplicação da equação de Young é mais qualitativa porque as condições de rigidez, homogeneidade e insolubilidade normalmente não são conhecidas. Podem ocorrer transformações na célula ou seus componentes podem ser transferidos para a fase liquida (ADANSON, 1990).

A técnica do ângulo de contato foi utilizada por VERRIER et al. (1988), no estudo de adesão de arqueas metanogênicas em superfícies poliméricas com diferentes graus de hidrofobicidade. Os autores observaram que superfícies hidrofóbicas, como polietileno, favoreceram a adesão de bactérias com parede 
celular hidrofóbica, como Methanothrix soehngenii FE, e concluíram que a adesão de arqueas metanogênicas em suportes inertes é influenciada pela superfície celular e pelas características do suporte. PASSIG (1997) estudou a formação de biofilme em superfície de PVC e verificou comportamento semelhante ao observado por VERRIER et al. (1988), nesse mesmo tipo de material suporte, ressaltando a importância das características físicas e químicas das superfícies, particularmente a hidrofobicidade, para a formação e sustentação de biofilmes.

\subsection{Interações Microbianas em Reatores Anaeróbios Tratando Águas Residuárias Contendo Sulfato}

Em reatores anaeróbios tratando águas residuárias contendo sulfato, ocorrem interações entre BRS, BA e AM (ISA et al. 1986b; HARADA et al. 1994). O principal parâmetro que controla as interações entre BRS e microrganismos não redutores de sulfato é a relação $\mathrm{DQO} /\left[\mathrm{SO}_{4}{ }^{2-}\right]$. Conforme já apresentado, em situações de relação $\mathrm{DQO} /\left[\mathrm{SO}_{4}{ }^{2-}\right]$ acima de 0,67 , os processos sulfetogênicos e metanogênicos podem ocorrer simultaneamente e, abaixo desse valor, a sulfetogênese pode ser o processo dominante. A compreensão das interações entre BRS, BA e AM é importante para a aplicação de processos biológicos anaeróbios com o objetivo de remoção de sulfato de águas residuárias.

MIZUNO et al. (1994) estudaram o efeito da concentração de sulfato e do tempo de retenção celular $\left(\theta_{C}\right)$ sobre as interações entre AM e BRS, em reator em batelada a $35^{\circ} \mathrm{C}$, utilizando butirato como doador de elétrons e fonte de carbono. Os autores observaram consumo total de butirato em todas as condições de relação $\mathrm{DQO} /\left[\mathrm{SO}_{4}{ }^{2-}\right]$ estudadas (1,5 a 148). Todavia, houve acúmulo de ácido acético quando os reatores foram submetidos a relações: $\mathrm{DQO} /\left[\mathrm{SO}_{4}{ }^{2-}\right]$ igual a 15 e $\theta_{\mathrm{C}}$ de 5 dias; $\mathrm{DQO} /\left[\mathrm{SO}_{4}{ }^{2-}\right]$ igual a 6 e $\theta_{\mathrm{C}}$ de 5 e 10 dias e, $\mathrm{DQO} /\left[\mathrm{SO}_{4}{ }^{2-}\right]$ igual a 3 com $\theta_{\mathrm{C}}$ de 10 e 20 dias. O acúmulo de ácido acético ocorreu devido à inibição dos microrganismos metanogênicos acetoclásticos, em conseqüência da presença de sulfeto total e sulfeto de hidrogênio livre.

De acordo com MIZUNO et al. (1994), a $\theta_{\mathrm{C}}$ de 20 dias, o fluxo de elétrons (\% da DQO total) utilizado pelas AM diminuiu de 98\% para 34\% com a diminuição da relação $\mathrm{DQO} /\left[\mathrm{SO}_{4}{ }^{2-}\right]$ de 148 para 1,5 , ao passo que a porcentagem de fluxo de 
elétrons utilizados pelas BRS aumentou de 2\% para $67 \%$. De outra forma, os autores verificaram que o fluxo de elétrons utilizado pelas BRS aumentou de $51 \%$ para $67 \%$, quando $\theta_{\mathrm{C}}$ foi diminuído de 20 para 5 dias, com relação $\mathrm{DQO} /\left[\mathrm{SO}_{4}{ }^{2-}\right]$ de 1,5 . Esses autores concluíram que, quando a relação $\mathrm{DQO} /\left[\mathrm{SO}_{4}{ }^{2-}\right]$ foi maior ou igual a 6 , a produção de metano foi predominante. Mais de $80 \%$ do doador de elétrons foram utilizados pelas arqueas metanogênicas. Porém, quando a relação $\mathrm{DQO} /\left[\mathrm{SO}_{4}{ }^{2-}\right]$ foi de 1,5 , a redução de sulfato foi predominante e mais de $50 \%$ do doador de elétrons foi utilizado pelas BRS. Houve rápido aumento do crescimento bacteriano no reator. Mesmo com a depleção do sulfato, as BRS foram quantificadas em grande número $\left(10^{6}\right.$ a $\left.10^{8} \mathrm{NMP} / \mathrm{mL}\right)$, em todos os reatores.

Em condições de escassez de sulfato, butirato foi degradado a metano via acetato e hidrogênio pelas AM. De outra forma, sob altas concentrações de sulfato (DQO/[ $\left.\mathrm{SO}_{4}{ }^{2-}\right]$ menor ou igual a 1,5$)$ butirato foi inicialmente degradado por BRS a acetato, e este degradado pelas AM e por BRS acetoclásticas.

Benzoato é um importante intermediário na degradação anaeróbia de compostos orgânicos aromáticos presentes em águas residuárias industriais. BRS são capazes de oxidar benzoato tanto em ambiente rico em sulfato como em ambientes onde há escassez desse íon. No primeiro caso, as BRS competem com as BSA pelo benzoato disponível e com as AM pelo hidrogênio e acetato. Quando há escassez de sulfato, as BRS interagem sintroficamente com as BSA e AM, oxidando uma fração do benzoato disponível produzindo acetato e $\mathrm{H}_{2}$, sustentando o crescimento de AM (LY et al., 1995).

OMIL et al. (1997) observaram que a competição entre BRS e AM por acetato, em reator com lodo granular, foi influenciada pela velocidade ascensional e pelo $\mathrm{pH}$. Os autores observaram que o lodo carreado para fora do reator devido às altas velocidades ascensionais aplicadas, continha alta capacidade em degradar acetato via sulfetogênese, ao passo que, sob essas condições, a atividade das AM acetoclásticas aumentou, sugerindo que as BRS acetoclásticas são mais susceptíveis aos efeitos da velocidade ascensional. O efeito do $\mathrm{pH}$ está relacionado com a toxicidade do $\mathrm{H}_{2} \mathrm{~S}$.

CALLADO (1992) observou aumento da concentração de ácidos voláteis no efluente de reator anaeróbio com manta de lodo (UASB) tratando água residuária 
sintética contendo glicose como a principal fonte de carbono e doador de elétrons, quando a concentração de sulfato no afluente foi superior a $2000 \mathrm{mg} . \mathrm{L}^{-1}$. Possivelmente, nessas condições, as BRS oxidadoras incompletas converteram compostos orgânicos intermediários em acetato, e a inibição da atividade metanogênica acetoclástica resultou no aumento da concentração de ácidos voláteis, particularmente, ácido acético.

VAZOLLER et al. (1996) propuseram uma rota biológica de degradação de compostos orgânicos para explicar a interação metabólica entre as culturas presentes no lodo granulado, submetido a elevadas concentrações de sulfato de sódio. Os autores concluíram que, se doadores de elétrons complementares estiverem presentes, as interações entre as BRS e AM serão positivas, ou seja, de sintrofismo. Por exemplo, para o caso da degradação da glicose, os autores propuseram que essa substância é fermentada produzindo outras mais simples, como lactato, por exemplo. Em seguida, as BRS oxidam parcialmente lactato a acetato, totalmente disponibilizado para as AM, uma vez que as BRS que realizam a oxidação incompleta de seus substratos orgânicos não utilizam o acetato.

\subsection{Efeitos do Sulfeto de Hidrogênio $\left(\mathrm{H}_{2} \mathrm{~S}\right)$ nos Processos Sulfetogênico e Metanogênico}

Segundo SPEECE (1983) o íon sulfeto é nutriente requerido por AM e tem sido demonstrado que esses microrganismos contêm mais enxofre do que outros geralmente encontrados em sistemas anaeróbios. Entretanto, o acúmulo de sulfeto em reatores anaeróbios pode causar severa inibição dos processos de tratamento de águas residuárias e até a falência total desses sistemas. Grandes quantidades de sulfeto podem ocasionar problemas devidos à precipitação de ferro, cobalto e níquel, essenciais para AM.

Muitos dos estudos referentes com toxicidade do sulfeto tiveram como foco principal a inibição da metanogênese. Para o estabelecimento das concentrações máximas de sulfeto permissíveis em reatores anaeróbios, os efeitos sobre as BA e as BRS devem ser considerados. Presume-se que o efeito inibitório do sulfeto seja devido à forma não dissociada $\left(\mathrm{H}_{2} \mathrm{~S}\right)$, porque somente moléculas podem permear a membrana celular (LENS et al.,1998). 
Atravessando a parede celular, a molécula de $\mathrm{H}_{2} \mathrm{~S}$ pode desnaturar proteínas ou importantes enzimas metabólicas por meio da formação de sulfeto e dissulfeto entre as cadeias polipeptídicas. Sulfeto de hidrogênio pode interferir com o metabolismo assimilativo do enxofre e também afetar o $\mathrm{pH}$ intracelular.

Estudos sob condições mesofílicas e termofílicas demonstraram que lodo granular é menos inibido por $\mathrm{H}_{2} \mathrm{~S}$ do que lodos em suspensão, a valores de $\mathrm{pH}$ baixos e neutros, enquanto que o grau de inibição é muito similar em altos valores de $\mathrm{pH}$, provavelmente devido ao gradiente de $\mathrm{pH}$ no interior dos grânulos (LENS et al., 1998). Entretanto, a condição de crescimento local pode ser diferente do meio líquido devido à limitação de transferência de massa, o que explica porque altas concentrações de sulfeto podem ser toleradas em reatores operando com biofilmes, em pH neutro (MAILLACHERUVU et al., 1993).

A inibição de AM devida ao sulfeto depende das características do lodo. Em lodos em suspensão, a inibição é determinada pela concentração de $\mathrm{H}_{2} \mathrm{~S}$ e pelo $\mathrm{pH}$. Há relatos de que concentrações de $\mathrm{H}_{2} \mathrm{~S}$ variando entre $50 \mathrm{mg} . \mathrm{L}^{-1}$ e $130 \mathrm{mg} . \mathrm{L}^{-1}$ inibiu em 50\% a atividade metanogênica (LENS et al., 1998). Com exceção das bactérias que degradam propionato, as $\mathrm{AM}$ são mais sensíveis à presença de $\mathrm{H}_{2} \mathrm{~S}$ do que as BA, em lodos em suspensão ou granulares. PAULA JR. (1992) observou que concentrações de $\mathrm{H}_{2} \mathrm{~S}$ de até $100 \mathrm{mg} . \mathrm{L}^{-1}$ estimularam a metanogênese, ao passo que concentrações superiores exerceram efeito inibitório. Segundo CALLADO (1992), a metanogênese foi estimulada pela adição de sulfato até a concentração de $400 \mathrm{mg} . \mathrm{L}^{-1}$ e passou a ser inibida em concentrações superiores a $2000 \mathrm{mg} \cdot \mathrm{L}^{-1}$. Essa autora concluiu que a metanogênese não foi inibida pela competição entre BRS e AM e tampouco pelo aumento na concentração de sulfeto no biogás (de 4\% para 6\%), mas a inibição ocorreu, provavelmente, pela forma em que sulfato foi adicionado (sulfato de sódio). Outra observação importante, no referido trabalho, é que a relação $\mathrm{DQO} /\left[\mathrm{SO}_{4}{ }^{2-}\right]$, variando entre 58,0 e 0,2 , não foi parâmetro decisivo no desempenho global do reator em termos de remoção de DQO. Posteriormente, SAKAMOTO (1996) avaliou o comportamento do consórcio microbiano existente em lodo granulado anaeróbio metanogênico submetido a adições crescentes de sulfato. Similarmente às observações anteriores (PAULA JR., 1992 e CALLADO, 1992), essa autora observou estimulação da metanogênese com aumento na concentração de 
sulfato de 284 mg. $\mathrm{L}^{-1}$ a $2130 \mathrm{mg} \cdot \mathrm{L}^{-1}$.

MAILLACHERUVU et al. (1993) relataram que concentrações de $\mathrm{H}_{2} \mathrm{~S}$ de 60 mg. $\mathrm{L}^{-1}$ a $75 \mathrm{mg} . \mathrm{L}^{-1}$ e concentrações de sulfeto dissolvido (SD) entre $150 \mathrm{mg} . \mathrm{L}^{-1} \mathrm{e}$ 200 mg. $\mathrm{L}^{-1}$ causaram stress em sistemas completamente misturados e que concentrações maiores causaram a falência de sistemas, quando alimentados com acetato e propionato.

Sistemas alimentados com lactato e glicose suportaram concentrações de $\mathrm{H}_{2} \mathrm{~S}$ entre $100 \mathrm{mg} \cdot \mathrm{L}^{-1}$ e $150 \mathrm{mg} . \mathrm{L}^{-1}$ e sulfeto dissolvido em concentrações entre 200 mg.L. $\mathrm{L}^{-1}$ e $400 \mathrm{mg} . \mathrm{L}^{-1}$, com perdas de eficiência em remoção de DQO e de sulfato. Os filtros anaeróbios foram mais resistentes a concentrações elevadas de $\mathrm{H}_{2} \mathrm{~S}$ e $\mathrm{SD}$, do que sistemas completamente misturados. Em filtro anaeróbio alimentado com propionato, concentrações de $\mathrm{H}_{2} \mathrm{~S}$ de $200 \mathrm{mg} . \mathrm{L}^{-1}$ e $\mathrm{SD}$ de $1.000 \mathrm{mg} . \mathrm{L}^{-1}$ foram toleradas, com pequeno efeito sobre o desempenho do sistema. Os autores observaram um comportamento cíclico da variação nas concentrações de $\mathrm{H}_{2} \mathrm{~S}, \mathrm{SD}$ e da DQO devida aos ácidos voláteis, em sistemas alimentados com acetato, propionato, lactato e glicose. O conhecimento desse comportamento envolvendo crescimento, inibição e adaptação de BRS é considerado um dos principais fatores para desenvolvimento de um modelo unificado que descreva as interações entre BRS e AM.

MAILLACHERUVU et al. (1996), estudando a cinética de crescimento e utilização de substrato por seis grupos de microrganismos presentes em sistemas anaeróbios utilizados para tratamento de águas residuárias, observaram que a toxicidade devida ao sulfeto sobre os microrganismos estudados, afeta, progressivamente, na seguinte ordem: AM hidrogenotróficas, BRS hidrogenotrófica, BRS que oxidam imcompletamente propionato, AM acetoclástica, fermentadores de propionato, BRS acetoclásticas. Esses resultados demonstraram que as vantagens cinética e termodinâmica das BRS acetoclásticas foram superadas pela sensibilidade desses microrganismos à toxicidade por sulfeto e que bactérias que fermentam propionato também foram sensíveis à presença de sulfeto.

O'FLAHERTY et al. (1999) adicionaram sulfeto, em concentrações crescentes, em lodo não alimentado com sulfato e observaram que as AM acetoclásticas foram os microrganismos mais sensíveis à inibição por sulfeto total 
(ST) e por sulfeto de hidrogênio $\left(\mathrm{H}_{2} \mathrm{~S}\right)$, com IC50 (concentração que inibe o crescimento de $50 \%$ dos microrganismos) de 980 mg. $\mathrm{L}^{-1}$ e 69 mg. $\mathrm{L}^{-1}$, respectivamente, em $\mathrm{pH} 8,0$. Quando o $\mathrm{pH}$ foi reduzido para 6,4, o valor de IC50 de ST diminuiu para $220 \mathrm{mg}$. $\mathrm{L}^{-1}$, com correspondente aumento na concentração de $\mathrm{H}_{2} \mathrm{~S}$ para $150 \mathrm{mg} \cdot \mathrm{L}^{-1}$. As bactérias consumidoras de butirato também foram sensíveis à toxicidade devida ao ST, com IC50 de $1.100 \mathrm{mg} . \mathrm{L}^{-1}$, correspondendo à concentração de $\mathrm{H}_{2} \mathrm{~S}$ igual a $77 \mathrm{mg} . \mathrm{L}^{-1}$ em $\mathrm{pH} 8,0$. Os autores observaram um fato interessante: o valor da IC50 para as bactérias consumidoras de propionato foi quase o dobro do valor para as AM acetoclásticas em pH 8,0, sendo que a degradação de propionato cessou quando ocorreu acúmulo de acetato. A causa dessa inibição foi atribuída ao aumento na pressão parcial de hidrogênio, já que as AM hidrogenofílicas foram inibidas pelas concentrações aplicadas de sulfeto. Também foi observado que a inibição da degradação de propionato foi irreversível, sugerindo que o efeito tóxico foi exercido pelo acetato sobre a população desses microrganismos, particularmente pelo acetato não dissociado, pois a toxicidade foi mais intensa quando o $\mathrm{pH}$ baixou de 8,0 para 6,5 .

$\mathrm{O}$ efeito inibitório do $\mathrm{H}_{2} \mathrm{~S}$ sobre as BRS tem sido abordado na literatura sob controvérsias. ISA et al. (1986b) relataram que altos níveis de sulfeto de hidrogênio (até $1000 \mathrm{mg} . \mathrm{L}^{-1}$ ) não afetaram o crescimento de BRS em reator anaeróbio de alta taxa, em escala de laboratório. Estudos posteriores revelaram que as BRS são inibidas por sulfeto dissolvido (MAILLACHERUVU et al. 1993).

O sulfeto de hidrogênio também causa efeito inibitório em bactérias aeróbias. Estudos realizados por CYBIS et al. (2002), indicaram que o sulfeto presente em concentrações entre $0,5 \mathrm{mg} . \mathrm{L}^{-1}$ e $2,0 \mathrm{mg} . \mathrm{L}^{-1}$ no efluente real de reator anaeróbio, tipo UASB, tratando esgoto de origem doméstica, alterou as propriedades cinéticas do lodo aeróbio de uma unidade subseqüente, utilizada como pós-tratamento e pode ter inibido o processo de nitrificação.

\subsection{Remoção de Sulfeto de Águas Residuárias}

Efluentes líquidos contendo sulfeto são gerados por inúmeras atividades industriais, além de efluentes de processos anaeróbios de tratamento de águas residuárias. Sulfeto pode ser oxidado, empregando-se sistemas de aeração não 
catalisados ou biocatalisados, eletroquimicamente, ou quimicamente, utilizando-se cloro, ozônio, permanganato de potássio ou peróxido de hidrogênio, com produção de enxofre elementar, tiossulfato ou sulfato, dependendo do $\mathrm{pH}$. Outros métodos considerados convenientes para remoção de sulfeto, são: precipitação com íons metálicos e o stripping do $\mathrm{H}_{2} \mathrm{~S}$. Entretanto, os consumos de substâncias e de energia, além da geração de resíduos constituem em desvantagens da utilização desses processos (LENS et al., 1998).

SILVA et al. (2002) observaram, em reator operado sob condição sulfetogênica, em pontos de amostragem expostos à luz, o crescimento de bactérias que utilizam o íon sulfeto como doador de elétrons e realizam fotossíntese na ausência de oxigênio (fotossíntese anoxigênica). Os autores também observaram a deposição de precipitado amarelado sobre o material suporte utilizado para imobilização de BRS. A análise por meio de fluorescência de Raios X com dispersão de energia (EDXRF) revelou que o precipitado continha $74 \%$ do elemento enxofre e, dessa porcentagem, $87 \%$ correspondia à forma elementar $\left(\mathrm{S}^{0}\right)$ e o restante estava combinado com outros elementos, principalmente, sódio.

Sulfeto de hidrogênio e dióxido de enxofre podem ser convertidos biologicamente a enxofre elementar como representado na Figura 3.5 (JANSSEN et al., 1999). O enxofre insolúvel pode ser removido do efluente tratado empregando-se processo de sedimentação. A recuperação de enxofre é potencialmente valiosa, pois pode ser utilizado na fabricação de ácido sulfúrico, insumo de ampla aplicação em processos industriais. 


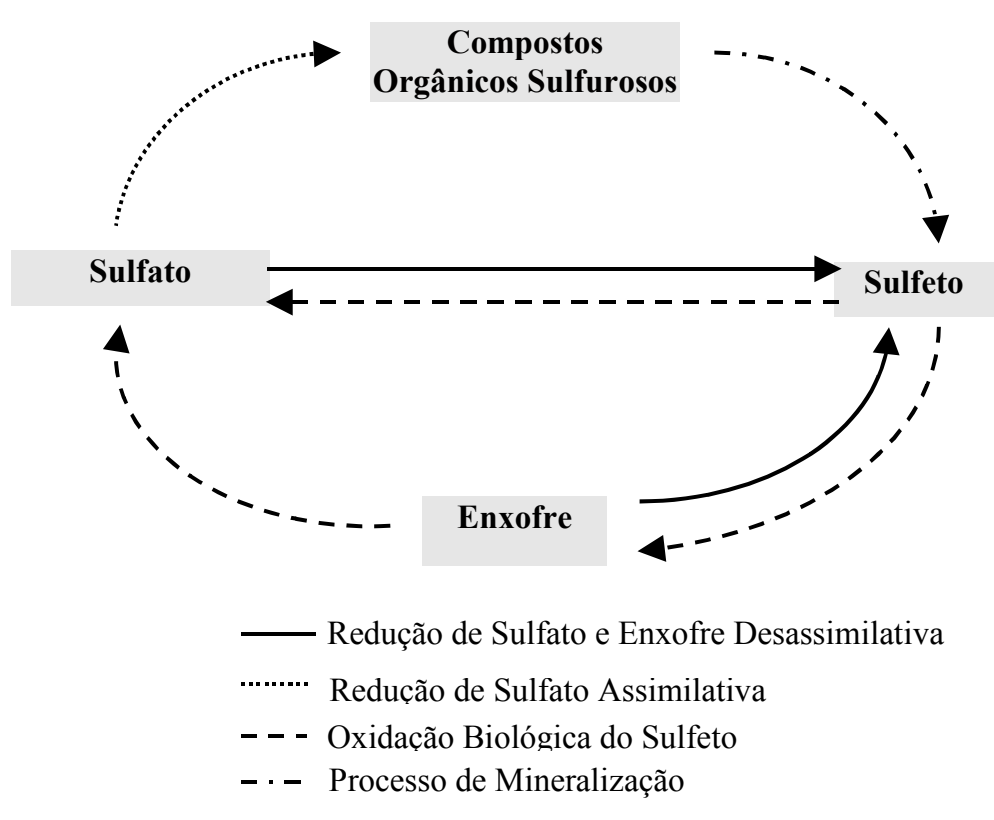

Figura 3.5. Ciclo Biológico do Enxofre (Adaptado de JANSEN et al., 1999).

A oxidação biológica de sulfeto a enxofre elementar pode ocorrer em condições aeróbias, anóxicas ou anaeróbias. Sob essas condições, oxigênio, nitrato ou dióxido de carbono, respectivamente, são usados como aceptores de elétrons. Em condição anaeróbia, microrganismos do gênero Chlorobiaceae e Chromatiaceae utilizam os elétrons do sulfeto para a redução e assimilação de $\mathrm{CO}_{2}$ e obtêm energia a partir da luz solar. A utilização desses microrganismos no processo pode requerer iluminação artificial para compensar a perda de luminosidade devida ao aumento da turbidez causado pelo enxofre produzido, o qual é insolúvel em água.

Outros microrganismos, não fotossintetizantes, oxidam sulfeto a enxofre ou a sulfato, reduzindo oxigênio e nitrato à $\mathrm{H}_{2} \mathrm{O}$ e $\mathrm{N}_{2}$, respectivamente. Nesses processos, $\mathrm{CO}_{2}$ é a principal fonte de carbono. Thiobacillus spp. tem alta afinidade por sulfeto, permitindo que sua utilização seja competitiva com os processos químicos oxidativos. Enxofre pode ser produzido mediante a oxidação incompleta de sulfeto por Thiobacillus sp., conforme a equação 3.5:

$$
2 \mathrm{HS}^{-}+\mathrm{O}_{2} \rightarrow 2 \mathrm{~S}^{0}+2 \mathrm{OH}^{-} \quad \Delta G^{0^{\prime}}=-169,35 \mathrm{~kJ} . \mathrm{molHS}^{-{ }^{-1}}
$$

Sob condições limitadas de oxigênio (OD $\leq 0,1 \mathrm{mg} . \mathrm{L}^{-1}$ ) $\mathrm{S}^{\mathrm{o}}$ é o principal produto final da oxidação do sulfeto. Sua formação requer quatro vezes menos oxigênio, comparado com a oxidação completa, consumindo menos energia. $\mathrm{O}$ 
enxofre residual pode ser recuperado por sedimentação. Entretanto, em reatores que são operados com alto tempo de retenção celular $\left(\theta_{c}\right)$, partículas de enxofre biologicamente produzidas formam agregados, nos quais Thiobacillus spp. se fixam. Sob condições de baixa tensão de cisalhamento, partículas com diâmetro médio de 3 $\mathrm{mm}$ sedimentam com velocidades maiores que $25 \mathrm{~m} / \mathrm{h}$. Isso permite que a carga máxima de sulfeto aplicada de $6 \mathrm{~g} \mathrm{HS} \cdot \mathrm{H}^{-1} \cdot \mathrm{d}^{-1} 1$, em reator operando com células suspensas, seja aumentada para $14 \mathrm{~g} \mathrm{HS}^{-} \cdot \mathrm{L}^{-1} \cdot \mathrm{d}^{-1}$, em reator com agregados. A imobilização de Thiobacillus spp. em agregados de $\mathrm{S}^{0}$ ocorre melhor sob condições autotróficas. Em condições heterotróficas, $\mathrm{S}^{\mathrm{o}}$ constituinte dos agregados pode ser reduzido a sulfeto (JANSEN et al., 1999).

O enxofre elementar biologicamente produzido tem coloração branca ou amarela palha, tem índice de refração maior que o da água e é classificado como líquido amorfo com base em resultados de difração de Raios X. O enxofre produzido por Chromatium spp. tem densidade igual a 1,22 g.cm (JANSEN et al.,1999). Os glóbulos de enxofre se convertem para a forma cristalina $\mathrm{S}_{8}$ quando são mantidos no estado líquido ou seco. Todavia, ainda não foi demonstrado se os glóbulos de enxofre consistem de enxofre puro. De acordo com JANSEN et al. (1999), muitas das propriedades dos glóbulos de enxofre biologicamente produzidos não combinam com as propriedades de qualquer forma alotrópica de enxofre elementar conhecida. Esses autores observaram diferenças, quanto à hidrofobicidade, entre suspensões de enxofre biologicamente produzido e de enxofre padrão, fluorescente, através de separação na mistura hexadecano-água. O padrão hidrofóbico amarelo do enxofre fluorescente permaneceu sobre a fase constituída por hexadecano, enquanto que o enxofre biologicamente produzido permaneceu abaixo da fase aquosa. Resultados de difração de Raios X indicaram que partículas de enxofre biologicamente produzidas foram parcialmente constituídas por cristais orto-rômbicos. O caráter hidrofílico do enxofre biologicamente produzido é conseqüente da presença de compostos anfílicos cobrindo os núcleos hidrofóbicos de $\mathrm{S}_{8}$. Esses compostos são politionatos de cadeia longa $\left(\mathrm{SO}_{3}-\mathrm{S}_{\mathrm{n}}-\mathrm{SO}_{3}, \mathrm{n}\right.$ igual a 5 a 20$)$ e foram detectados através de cromatografia líquida, a $\mathrm{pH}$ 8. Outros compostos podem ser responsáveis pela natureza hidrofílica do enxofre. Politionatos são quimicamente instáveis em $\mathrm{pH} 7$, sendo essa a razão da ausência desses compostos sob essa condição. 
Para a separação do enxofre elementar produzido em biorreatores podem ser empregados diversos processos, por exemplo: sedimentação, filtração, flotação, extração e processos de membrana. Evidentemente, a sedimentação das partículas de enxofre é o método de separação mais atrativo economicamente.

Os tamanhos dos agregados de enxofre relacionam-se diretamente com as taxas de carregamento de sulfeto no reator biológico. Segundo JANSEN et al. (1999), o mecanismo para a formação desses agregados não é completamente conhecido. Esses autores demonstraram que podem ocorrer interação eletrostática e repulsão estérica, bem como ligações entre partículas de enxofre e o microrganismos. As interações entre as partículas são fracas e, por isso, os agregados de enxofre são continuamente desfeitos pela ação de forças de cisalhamento, quando a suspensão no reator for vigorosamente agitada ou aerada. Os autores desenvolveram um reator de leito expandido (Figura 3.6) para a oxidação parcial de sulfeto a enxofre elementar.

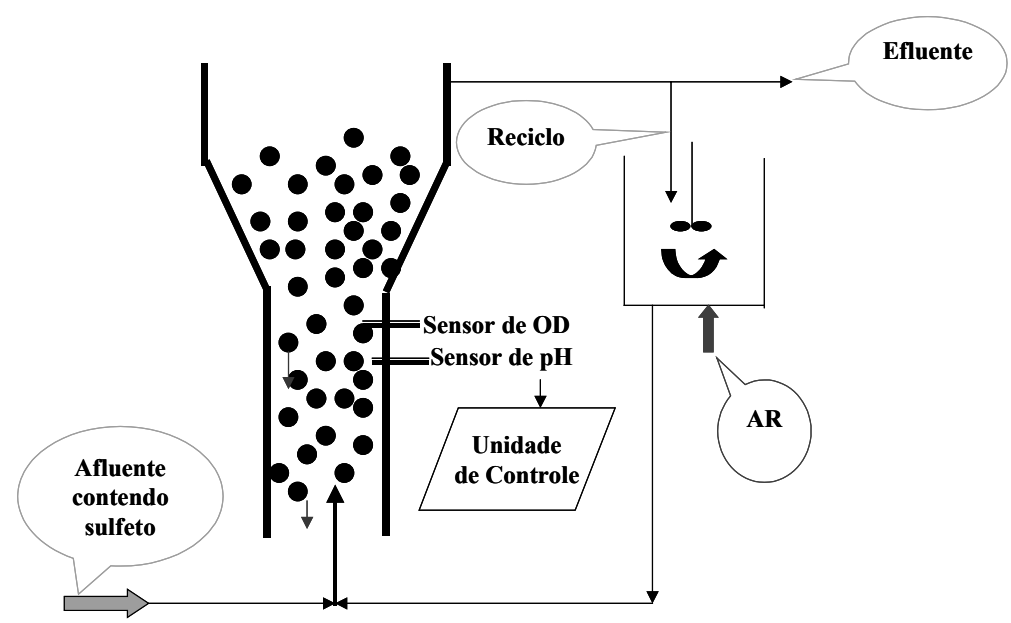

Figura 3.6. Esquema de reator de leito expandido com unidade de aeração externa, utilizado para oxidação parcial de sulfeto e recuperação de enxofre elementar (JANSSEN et al., 1999)

A configuração do reator apresentada pela Figura 3.6 foi concebida de forma a tentar-se diminuir o efeito das forças de cisalhamento. Nesse sistema, a aeração da fase líquida e a oxidação de sulfeto a enxofre elementar são processos espacialmente separados. Segundo os autores, após 50 dias de operação, 90\% do lodo sedimentava com velocidade maior que $25 \mathrm{~m} \cdot \mathrm{h}^{-1}$. 
Outras configurações de reatores, como por exemplo, reatores operados em bateladas seqüenciais (SBR), podem ser utilizados no processo de oxidação biológica do sulfeto com recuperação de enxofre. Todavia, os sistemas de mistura e aeração devem ser projetados de forma a resultar em menores forças de cisalhamento possíveis.

\subsection{Considerações Finais}

Apesar do processo de biodessulfatação ocorrer naturalmente em águas que contêm oxiânions de enxofre, somente a partir da década de 80 pesquisas envolvendo esse processo foram intensificadas. Por exemplo, estudos realizados por ISA et al. (1986a) abordaram os aspectos técnicos do processo de redução de sulfato, relacionado à produção de metano na digestão anaeróbia em reatores de alta taxa, com biomassa imobilizada em espuma de poliuretano. Esses autores observaram que a atividade metanogênica sofreu inibição de até $12 \%$, com concentrações de sulfato de $5000 \mathrm{mg} . \mathrm{L}^{-1}$ e DQO média igual a $5076 \mathrm{mg} . \mathrm{L}^{-1}$. Além disso, acetato como único doador de elétrons e fonte de carbono foi um substrato pior para BRS, que a mistura de acetato e etanol na proporção de 1,7:1, em massas. Outra observação importante neste trabalho foi que as AM acetoclásticas e hidrogenotróficas foram inibidas por sulfeto de hidrogênio livre $\left(\mathrm{H}_{2} \mathrm{~S}\right)$ na fase líquida, somente a concentrações superiores

a $1000 \mathrm{mg} \cdot \mathrm{L}^{-1}$ devido, provavelmente, à adaptação desses microrganismos ao $\mathrm{H}_{2} \mathrm{~S}$. As BRS foram também afetadas pelo $\mathrm{H}_{2} \mathrm{~S}$, e não se sabe ainda se a inibição de AM e de $\mathrm{BRS}$ foi devida à toxicidade do $\mathrm{H}_{2} \mathrm{~S}$ (efeito direto) ou à indisponibilidade de elementos metálicos essenciais, em quantidades traços, para esses microrganismos, que poderiam estar precipitados como sulfetos (ISA et al., 1986a). De acordo com ISA et al. (1986a), a presença de sulfato não apresentou efeito inibitório relevante sobre a metanogênese em reatores de alta taxa. Somente concentrações de sulfato superiores a 10 g. $\mathrm{L}^{-1}$, afetaram a digestão anaeróbia não somente pelo sulfato ou sulfeto produzido, mas também pela concentração de sódio. Resultados semelhantes foram obtidos por CALLADO (1992) em estudo da toxicidade do sulfato sobre o processo metanogênico em reator anaeróbio de fluxo ascendente e manta de lodo (UASB).

Uma importante revisão sobre o processo de biodessulfatação foi realizada 
por LENS et al (1998). Esses autores ressaltaram que águas residuárias contendo sulfato e outros oxiânions de enxofre têm origem em diversos processos industriais e que a presença desses compostos em águas residuárias devem ser consideradas no projeto de sistemas de tratamento. Isso previne a inibição da metanogênese e possibilita a aplicação de processos com finalidade de remoção de matéria orgânica, somente por BRS ou por BRS e microrganismos que oxidam sulfeto, utilizando o ciclo biológico do enxofre, remoção de metais pesados e nitrogênio e redução na produção de lodo (LENS et.al.,1998). Segundo esses autores, na digestão anaeróbia de água residuária contendo sulfato ocorre competição entre BRS e AM pelo doador de elétrons disponível. Essa competição não era prevista em modelos mais antigos para controle de reatores biológicos e nem havia métodos práticos para direcionar a competição entre esses dois tipos de microrganismos.

A aplicação de redução de sulfato em combinação com técnicas de remoção de sulfeto, e em particular, a oxidação parcial até enxofre elementar $\left(\mathrm{S}^{0}\right)$, pode ser usada para a remoção de sulfato de águas residuárias. Para se obter completa redução de sulfato, a água residuária deve ter relação $\mathrm{DQO} /\left[\mathrm{SO}_{4}{ }^{2-}\right]$ mínima de 0,67. Se essa relação for menor, será necessário adicionar doador de elétrons e fonte de carbono externa (por exemplo, metanol, etanol, ou $\mathrm{H}_{2}$ ). A oxidação parcial de sulfeto a $\mathrm{S}^{0}$ requer concentração de oxigênio dissolvido abaixo de $0,1 \mathrm{mg} . \mathrm{L}^{-1}$ (LENS et al., 1998). 


\section{MATERIAL E MÉTODOS}

Nessa seção são apresentados os materiais e métodos utilizados para o desenvolvimento do ensaio de imobilização da biomassa em materiais suporte inertes e para o estudo do desempenho dos reatores anaeróbios contendo biomassa imobilizada, operados em bateladas seqüenciais, com finalidade de remoção de sulfato de água residuária sintética com relação $\mathrm{DQO} /\left[\mathrm{SO}_{4}{ }^{2-}\right]$ de 3,$2 ; 1,3$; e 0,4 . Posteriormente, descreve-se a metodologia utilizada para avaliação do efeito de etanol sobre o processo sulfetogênico, como fonte externa de carbono e elétrons e, finalmente, a metodologia utilizada para estudo do processo de oxidação parcial do sulfeto por microrganismos em reator aeróbio operado em bateladas seqüenciais sob baixa concentração de oxigênio dissolvido.

\subsection{Ensaio de Imobilização da Biomassa em Materiais suporte Inertes}

\subsubsection{Configuração dos Reatores}

Essa etapa experimental teve como objetivo a avaliação de aderência microbiana em materiais suporte a serem utilizados no reator anaeróbio operado em bateladas seqüenciais. Os suportes foram avaliados em relação à capacidade de aderência de BRS. Para isso, foram utilizados reatores diferenciais com capacidade para $15 \mathrm{~mL}$, confeccionados em vidro borossilicato, providos de tampas de teflon, e vedados com anéis de borracha tipo o-ring, como mostra a Figura 4.1. 


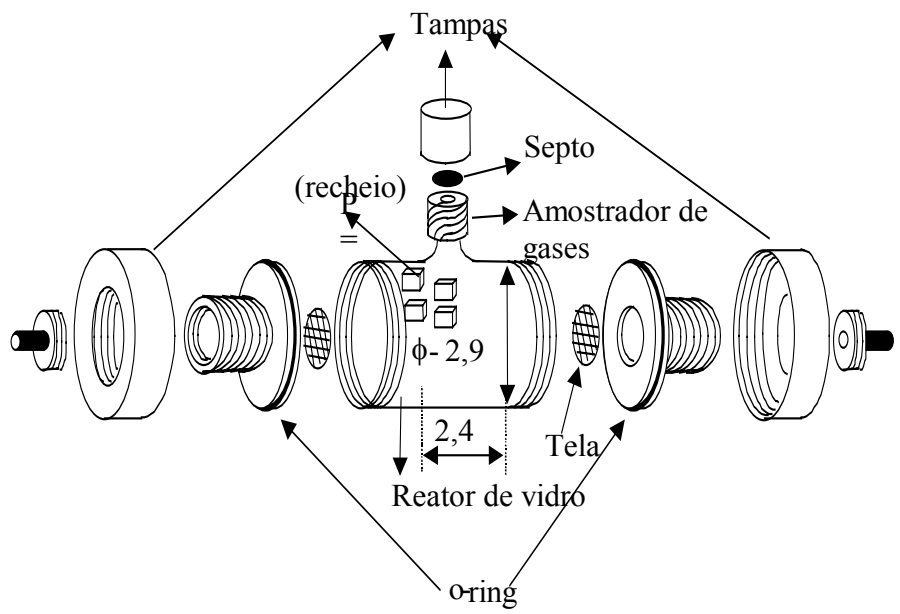

Figura 4.1. Reator Diferencial (Adaptado por RIBEIRO, 2001)

\subsubsection{Materiais Utilizados como Suporte para Imobilização de Biomassa}

Foram selecionados, arbitrariamente, cubos de espuma de poliuretano (PU) com $0,5 \mathrm{~cm}$ de aresta, partículas de carvão vegetal, de eucalípto (CV) de diâmetro médio de $0,4 \mathrm{~cm}$, partículas de polietileno de baixa densidade, reciclado (PE), com diâmetro médio de $0,4 \mathrm{~cm}$ e cubos de cerâmica porosa confeccionada com alumina (CE), de 0,4 cm de aresta. Esses materiais foram submetidos a ensaios de imobilização em reatores diferenciais com a finalidade de selecionar os dois tipos de material suporte (MS) a serem utilizados na imobilização de BRS nos reatores anaeróbios operados em bateladas seqüenciais, com biomassa imobilizada (ASBBR).

A Tabela 4.1 apresenta as principais características dos MS, os quais, exceto PE, foram caracterizados no Centro de Caracterização e Desenvolvimento de Materiais (CCDM), Laboratório de Análise de Materiais Particulados, UFSCar.

Tabela 4.1. Características dos Materiais Suporte

\begin{tabular}{ccccc}
\hline & PU & CV & CE & PE \\
\hline Forma & Cúbica & Cúbica & Cúbica & Cilíndrica \\
Densidade Aparente $\left(\mathrm{g} \cdot \mathrm{mL}^{-1}\right)$ & 0,023 & 0,51 & 0,46 & 0,40 \\
Diâmetro Equivalente* $(\mathrm{cm})$ & 0,6 & 0,5 & 0,5 & 0,5 \\
Porosidade & 0,92 & 0,43 & 0,75 & n.a. \\
Diâmetro médio dos poros $(\mu \mathrm{m})$ & 543 & 1,9 & 84,7 & n.a. \\
\hline
\end{tabular}

*Comparado a uma esfera de volume igual; n.a.: Não Analisado 


\subsection{3 Água Residuária Sintética}

A água residuária sintética foi preparada com base na metodologia descrita por TORRES (1992). Dessa forma, o meio sintético teve a seguinte composição: extrato de carne $\left(0,42\right.$ g. $\left.\mathrm{L}^{-1}\right)$, amido $\left(0,23 \mathrm{~g} . \mathrm{L}^{-1}\right)$, sacarose $\left(0,07 \mathrm{~g} . \mathrm{L}^{-1}\right)$, óleo de soja $\left(0,11 \mathrm{~mL} \cdot \mathrm{L}^{-1}\right)$, detergente neutro $\left(0,2 \mathrm{~mL} \cdot \mathrm{L}^{-1}\right), \mathrm{NaHCO}_{3}\left(0,4 \mathrm{~g} \cdot \mathrm{L}^{-1}\right), \mathrm{NaCl}(250$ mg. $\left.\mathrm{L}^{-1}\right), \mathrm{MgCl}_{2}\left(7,0 \mathrm{mg} \cdot \mathrm{L}^{-1}\right) ; \mathrm{CaCl}_{2}\left(4,5 \mathrm{mg} \cdot \mathrm{L}^{-1}\right)$ e $\mathrm{Na}_{2} \mathrm{SO}_{4}\left(3 \mathrm{~g} . \mathrm{L}^{-1}\right)$. Nessa etapa, os valores da DQO e da concentração de sulfato da água residuária sintética foram 1234 $( \pm 282) \mathrm{mg} . \mathrm{L}^{-1}$ e $1375( \pm 260) \mathrm{mg} . \mathrm{L}^{-1}$, respectivamente. Esses valores resultaram em relação $\mathrm{DQO} /\left[\mathrm{SO}_{4}{ }^{2-}\right]$ igual 0,9 .

\subsubsection{Procedimento Experimental}

Quatro reatores diferenciais foram utilizados para cada tipo de MS investigado. Os reatores, preenchidos com os respectivos MS, foram submetidos à velocidade de escoamento superficial de $0,03 \mathrm{~cm} . \mathrm{s}^{-1}$, utilizando-se uma bomba peristáltica marca Watson-Marlow ${ }^{\circledR}$ para bombear $0,5 \mathrm{~L}$ de esgoto sintético contendo sulfato, que era acondicionado em frascos de Duran mantidos sob agitação magnética (Agitadores Mecânicos marca Fisatom ${ }^{\circledR}$ ) e a $5^{\circ} \mathrm{C}$ (banho de gelo) para minimizar a ocorrência de reações bioquímicas fora dos reatores.

$\mathrm{Na}$ ocasião do bombeamento, antes de chegar aos reatores, o esgoto sintético passava por um banho-maria (Marconi ${ }^{\circledR}$ ) mantido a $30^{\circ} \mathrm{C}$. Os reatores foram mantidos numa incubadora $\left(\right.$ Marconi $^{\circledR}$ ) para garantir temperatura constante a $30^{\circ} \mathrm{C}$. A água residuária era recirculada em circuito fechado e substituída a cada 24 horas (Figura 4.2).

Para iniciar a formação de biofilme, lodo granular proveniente de um reator anaeróbio de fluxo ascendente e manta de lodo (UASB) alimentado com água residuária de abatedouro de aves (Avícola Dacar, SP), foi macerado em liquidificador e adicionado diariamente à água residuária sintética, de maneira a resultar em concentração de sólidos totais voláteis (STV) próxima a $100 \mathrm{mg}$. $\mathrm{L}^{-1}$. Esse tipo de inóculo foi utilizado por apresentar satisfatória diversidade microbiana, inclusive de BRS.

Em intervalos de sete dias, retirava-se um reator com cada MS do aparato experimental. As matrizes colonizadas eram acondicionadas em frascos de 
antibiótico com capacidade para $30 \mathrm{~mL}$, sob fluxo de nitrogênio, lacradas e preservadas em geladeira até serem submetidas às análises de STV e a exames microbiológicos.

Para análise de STV, a biomassa retida em PU e em PE foi desprendida por agitação mecânica manual de frascos, adicionando-se $50 \%(\mathrm{v} / \mathrm{v})$ de água destilada e pérolas de vidro em quantidade equivalente a quatro vezes o peso das matrizes de MS colonizadas.

A biomassa retida em $\mathrm{CV}$ e $\mathrm{CE}$ foi desprendida também através de agitação manual dos frascos contendo $50 \%$ (v/v) de água destilada. Nesse caso, não foram adicionadas pérolas de vidro e a quantificação do carvão perdido por desgaste devido ao atrito entre as partículas foi obtida pela realização de um ensaio-controle (branco), com amostras de $\mathrm{CV}$ isentas de biomassa previamente hidratadas com água de torneira.

Esse estudo foi realizado em duas etapas, inicialmente com PU e CV, seguido do ensaio com CE e PE.

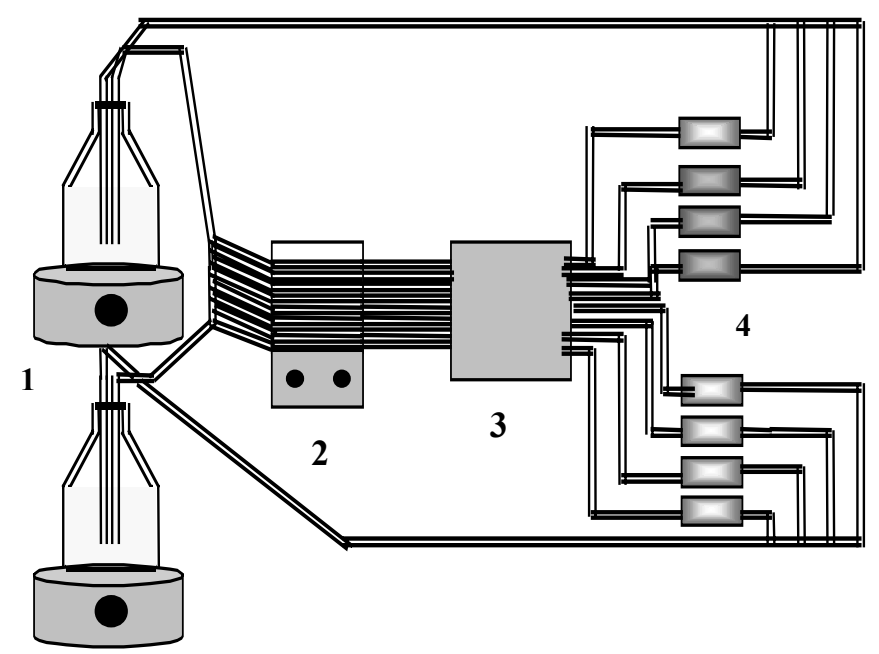

Figura 4.2. Instalação Experimental para Ensaios em Reatores Diferenciais:

1- Reservatórios Contendo Substrato Refrigerado e Sob Agitação; 2- Bomba

Peristáltica; 3 - Banho Maria $\left(30^{\circ} \mathrm{C}\right) ; 4$-Distribuição dos Reatores Diferenciais.

\subsubsection{Monitoramento e Procedimentos Analíticos}

Os exames de microscopia ótica (luz comum, contraste de fase e fluorescência) foram realizados utilizando-se microscópio Olympus BX60-FLA com 
sistema de aquisição de imagem (software Image Pro-Plus ${ }^{\circledR}$ ) e os exames de microscopia eletrônica de varredura (MEV) foram realizados utilizando-se microscópio eletrônico de varredura DSM-960 marca ZEISS no IFSC, após tratamento das amostras conforme metodologia descrita por NATION (1983) e adaptada por ARAÚJO (1995). Os grupos microbianos aderidos nos MS foram avaliadas através da técnica de biologia molecular de hibridização in-situ (FISH) por HIRASAWA (2003).

A hidrofobicidade da superfície da biomassa e dos MS foi determinada pela técnica do ângulo de contato formado por uma gota de água sobre a superfície dos materiais. Os materiais eram dispostos sobre uma lâmina de vidro, e na face paralela a esta se adicionava $1 \mu \mathrm{L}$ de água destilada. Um microscópio marca MM Optics ${ }^{\circledR}$, com aumento de 20 vezes, foi acoplado a uma câmara de vídeo LG $^{\circledR}$ modelo CCM. As imagens eram armazenadas num sistema de aquisição compatível com o sistema operacional Windows ${ }^{\circledR}$. O ângulo de contato foi medido através das ferramentas disponíveis no software Corel-Draw ${ }^{\circledR}$. Esse procedimento foi desenvolvido no Instituto de Física de São Carlos (IFSC-USP).

As variáveis DQO (demanda química de oxigênio) e concentração de sulfato $\left(\left[\mathrm{SO}_{4}{ }^{2-}\right]\right)$ foram determinadas semanalmente conforme os métodos 5520 e 4500 Sulfate, respectivamente (APHA, 1998).

\subsection{Operação dos Reatores em Batelada (ASBBR) - Processo de Biodessulfatação}

\subsubsection{Configuração dos Reatores}

Nessa etapa experimental foram concebidos dois reatores idênticos de acrílico com volume total de 10 litros para operar em bateladas seqüenciais, sendo construídos na oficina mecânica da EESC-USP nas seguintes dimensões: diâmetro interno de $220 \mathrm{~mm}$ e altura de $258 \mathrm{~mm}$. A concepção deste reator foi baseada na proposta original de RATUSZNEI et al. (2000) com modificações propostas por CUBAS et al. (2004).

$\mathrm{Na}$ parte inferior de cada reator havia uma zona de acúmulo de lodo de geometria cônica perfazendo um volume de $450 \mathrm{~mL}$ (4,5\% do volume total de cada 
reator). Logo acima da zona de lodo, foram alocadas tomadas para adaptação das mangueiras de alimentação e drenagem de líquido, e no fundo, uma tomada para adaptação de válvula para drenagem de lodo. Na parte central havia um ponto de amostragem de líquido.

$\mathrm{Na}$ parte interna de cada reator foi adaptado um anel de acrílico para sustentação de um cesto confeccionado com chapa de aço inox perfurado com 180 milímetros de diâmetro e altura, utilizado para acondicionamento dos MS.

Os reatores foram providos de sistema de agitação mecânica marca Fisaton ${ }^{\circledR}$, modelo 713D, com impelidores tipos turbina de $6 \mathrm{~cm}$ de diâmetro. O eixo do agitador foi alocado no centro de cada reator, dentro do cesto de inox perfurado para evitar o contato com o MS. A Figura 4.3 apresenta um esquema detalhado do reator anaeróbio com biomassa imobilizada e operado em bateladas seqüenciais. A bucha deslizante de teflon que revestia o furo central na tampa do reator foi substituída por um tubo de acrílico com diâmetro suficiente para possibilitar o funcionamento do eixo do agitador livre de atrito. O tubo de acrílico era imerso no líquido durante a operação dos reatores para evitar o escape de gás. 


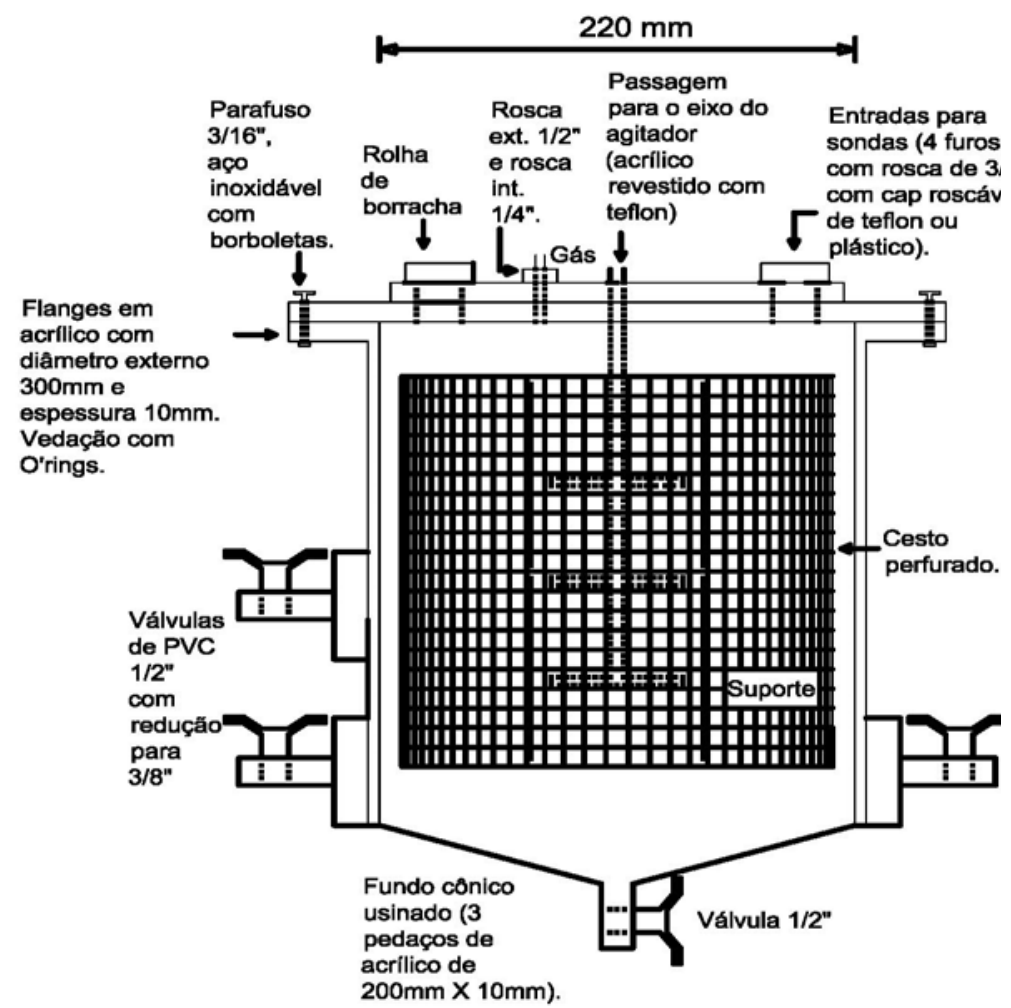

Figura 4.3. Reator Anaeróbio Utilizado para Operação em Bateladas Seqüenciais e com Biomassa Imobilizada em Material Suporte Inerte.

\subsubsection{Materiais Suporte Utilizados para Imobilização de Microrganismos}

Mediante ao estudo de adesão, descrito no item 4.1, foram selecionados dois MS para imobilizar, particularmente, BRS: CV e PU. Os dois materiais foram cortados em cubos com $1 \mathrm{~cm}$ de aresta e acondicionados no cesto de aço inoxidável no interior de cada reator. As características físicas desses MS são idênticas às apresentadas no item 4.1.2.

\subsubsection{Instalação Experimental}

Os reatores anaeróbios contendo os MS devidamente acondicionados foram instalados no interior de uma câmara de madeira, com temperatura controlada a $30 \pm 2^{\circ} \mathrm{C}$ por um sistema de medição e controle de temperatura, marca $T \& S^{\circledR}$. A 
Figura 4.4 apresenta a instalação a experimental, que inclui as bombas dosadoras marca Prominent ${ }^{\circledR}$ utilizadas para alimentação e descarga do efluente dos reatores.

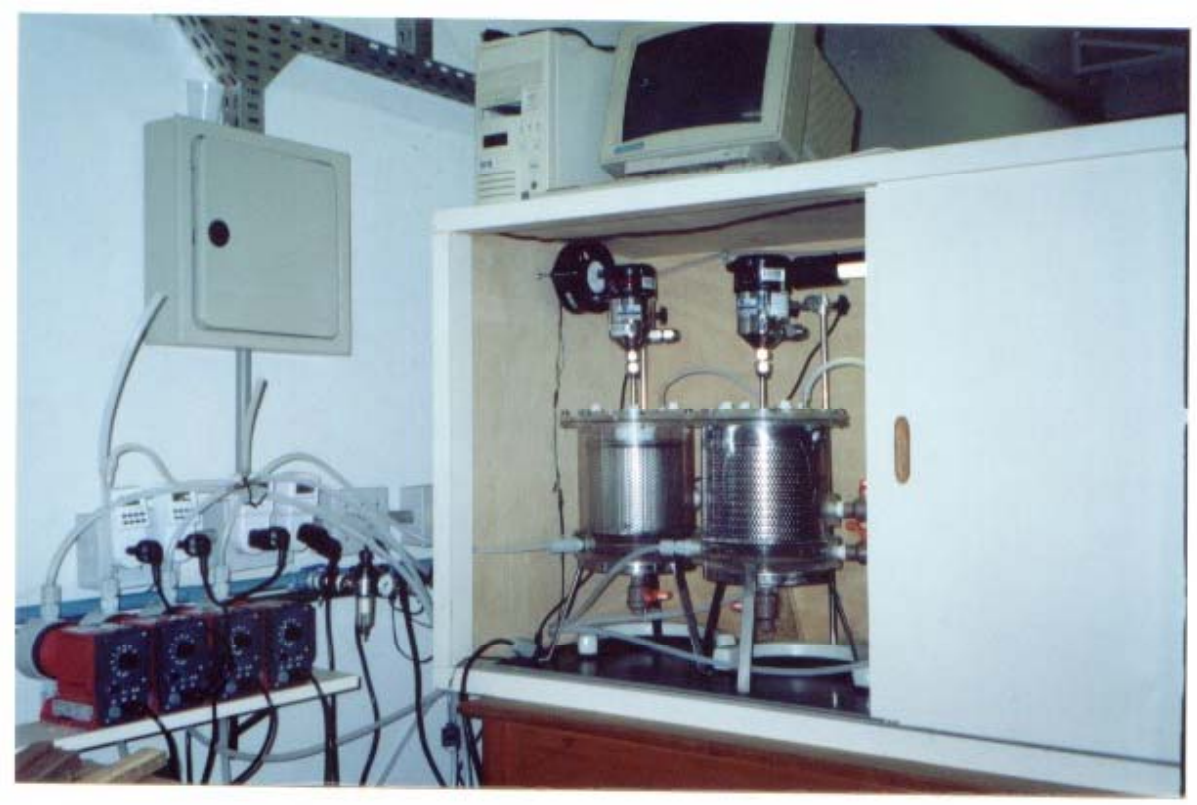

Figura 4.4. Instalação Experimental - ASBBR

\subsection{4 Água Residuária Sintética}

O processo de biodessulfatação foi estudado em duas etapas. Inicialmente, avaliou-se o desempenho dos ASBBR's contendo PU e CV no tratamento de água residuária sintética com relações $\mathrm{DQO} /\left[\mathrm{SO}_{4}{ }^{2-}\right]$ iguais a 3,$2 ; 1,3 ;$ e 0,4 . Nessas condições, sulfato de sódio foi adicionado ao meio, preparado conforme descrito no item 4.1.3, nas concentrações: $500 \mathrm{mg} . \mathrm{L}^{-1} ; 1200 \mathrm{mg} . \mathrm{L}^{-1}$, e $3000 \mathrm{mg} . \mathrm{L}^{-1}$. Posteriormente, avaliou-se o efeito de etanol sobre o processo sulfetogênico. $\mathrm{Na}$ condição em que os reatores apresentaram pior desempenho em remoção de sulfato adicionou-se etanol ao meio, em quantidade estequiométrica, de acordo com a equação 4.1, que representa a oxidação incompleta de etanol pela maioria das BRS (HANSEN, 1994).

$\mathrm{C}_{2} \mathrm{H}_{5} \mathrm{OH}+2 \mathrm{SO}_{4}^{2-}+16 \mathrm{H}^{+}+14 e^{-} \rightarrow \mathrm{C}_{2} \mathrm{H}_{4} \mathrm{O}+2 \mathrm{HS}^{-}+8 \mathrm{H}_{2} \mathrm{O}$

Em cada relação DQO/[ $\left.\mathrm{SO}_{4}{ }^{2-}\right]$ inicial avaliada e no estudo do efeito de etanol sobre o processo sulfetogênico, foram obtidos perfis temporais das variáveis DQO, 
[ $\left.\mathrm{SO}_{4}{ }^{2-}\right]$ e ácidos voláteis, particularmente, ácido acético, para modelação e obtenção de parâmetros cinéticos.

\subsubsection{Monitoramento e Procedimentos Analíticos}

Desde a partida, incluindo o período de inoculação os reatores foram monitorados com freqüência mínima de duas vezes por semana. As variáveis analisadas na fase líquida foram: $\mathrm{pH}$; potencial redox (ORP), alcalinidade total (AT), alcalinidade a bicarbonato (AB), ácidos totais voláteis (ATV), DQO, [ $\left.\mathrm{SO}_{4}{ }^{2-}\right]$, concentração de sulfeto total ([ST]), sólidos suspensos totais (SST), sólidos suspensos voláteis (SSV); concentração de ácido acético ([Hac]). $\mathrm{Na}$ fase gasosa monitorou-se a concentração de metano $\left(\mathrm{CH}_{4}\right)$ e sulfeto de hidrogênio $\left(\mathrm{H}_{2} \mathrm{~S}\right)$. Na fase sólida, aderida aos materiais suporte, foram determinadas as concentrações de SSV e realizadas análises microbiológicas com a finalidade de observar as formas morfológicas e quantificar os microrganismos pertencentes aos Domínios Archaea e Bacteria, incluindo as espécies de BRS por FISH (Hibridação Fluorescente in situ).

A hibridação fluorescente in situ (FISH) foi utilizada para quantificar e caracterizar os microrganismos presentes nas porções inferior, meio, e superior dos ASBBR's contendo biomassa imobilizada em PU e CV, tratando água residuária sintética com relação $\mathrm{DQO} /\left[\mathrm{SO}_{4}{ }^{2-}\right]$ igual a 0,4 . A metodologia utilizada foi a mesma descrita por DOMINGUES (2002).

As amostras foram hibridadas com sondas de oligonucleotídeos fluorescentes, as quais são específicas para as regiões do RNAr 16S, correspondentes aos Domínios Archaea e Bacteria e para o grupo geral das BRS Gram negativas da subdivisão Delta de Proteobacteria. Todas as sondas foram marcadas com o corante fluorescente rodamina, na extremidade $5^{\prime}$. As especificidades das sondas, as seqüências de bases dos oligonucleotídeos e as posições de hibridação do RNAr 16S estão descritas na Tabela 4.2.

A sonda NON338, cuja seqüência de nucleotídeos não se híbrida a nenhum RNAr microbiano conhecido atualmente (MANZ et al., 1992), foi utilizada como controle negativo para verificar a ocorrência de hibridações não específicas e de células auto-fluorescentes.

As sondas EUB338 e SRB385 foram utilizadas para detectar os organismos pertencentes ao Domínio Bacteria e ao grupo geral das BRS, respectivamente 
(AMANN et al., 1990). Para o Domínio Archaea foi utilizada a sonda ARC915 (RASKIN et al., 1994).

Tabela 4.2. Sondas de Oligonucleotídeos Utilizadas na Hibridação in situ.

\begin{tabular}{cccc}
\hline Sonda & Especificidade & Seqüência $\left(5^{\prime} \rightarrow 3^{\prime}\right)^{*}$ & Referência \\
\hline NON338 & Controle Negativo & ACTCCTACGGGAGGCAGC & MANZ et al., 1992 \\
EUB338 & Domínio Bacteria & GCTGCCTCCCGTAGGAGT & AMANN et al., 1990 \\
& Bactérias redutoras de & CGGCGTCGCTGCGTCAGG & AMANN et al., 1990 \\
SRB385 & sulfato & GTGCTCCCCCGCCAATTCCT & RASKIN, 1994 \\
\hline
\end{tabular}

*Seqüência de bases obtidas por AMANN et al. (1995).

Para cada condição estudada foram retiradas 3 cubos de PU, com auxílio de pinça estéril, transferidos para frasco de antibiótico contendo $2,5 \mathrm{~g}$ de pérolas de vidro e 5,0 mL de tampão salino fosfato (PBS: $130 \mathrm{mM} \mathrm{NaCl}, 7 \mathrm{mM} \mathrm{Na}_{2} \mathrm{HPO}_{4}, 3 \mathrm{mM}$ $\mathrm{Na}_{2} \mathrm{H}_{2} \mathrm{PO}_{4}$ ). Este sistema foi mantido sob atmosfera de $\mathrm{N}_{2}$ e $\mathrm{CO}_{2}(70: 30)$ por 5 minutos, submetido à agitação manual em ângulo de $45^{\circ}$, durante 20 minutos, e agitado em vórtex por mais 5 minutos para adequada separação dos arranjos celulares. Após o desprendimento, as amostras foram acondicionadas, em duplicata, em tubos de microcentrífuga de 1,5 mL para o procedimento de fixação.

Para a fixação, as amostras acondicionadas foram centrifugadas sob refrigeração $\left(4^{\circ} \mathrm{C}\right)$, durante 1 minuto a $9000 \mathrm{rpm}$, lavadas duas vezes com o mesmo volume em PBS (10x); ressuspendidas em $200 \mu \mathrm{L}$ de PBS (10x) mais $600 \mu \mathrm{L}$ de tampão de fixação com paraformaldeído $4 \%$, por 14 horas a $4{ }^{\circ} \mathrm{C}$. Após esse período, as amostras foram lavadas 3 vezes, por 1 minuto, em PBS (10x) e armazenadas a $-20{ }^{\circ} \mathrm{C}$ em tubos de microcentrífuga contendo 50\% de etanol e 50\% de PBS (10x).

Para a realização da hibridação in situ foram utilizadas lâminas de vidro (CEL-LINE/ERIE SCIENTIFIC CO.), revestidas com teflon, com 12 concavidades, cada uma com $7 \mathrm{~mm}$ de diâmetro (Figura 4.5). 
As lâminas foram mantidas em solução de hidróxido de potássio $10 \%$, durante 40 minutos, enxaguadas com água destilada e secas em estufa a $45^{\circ} \mathrm{C}$ (DOMINGUES, 2002).

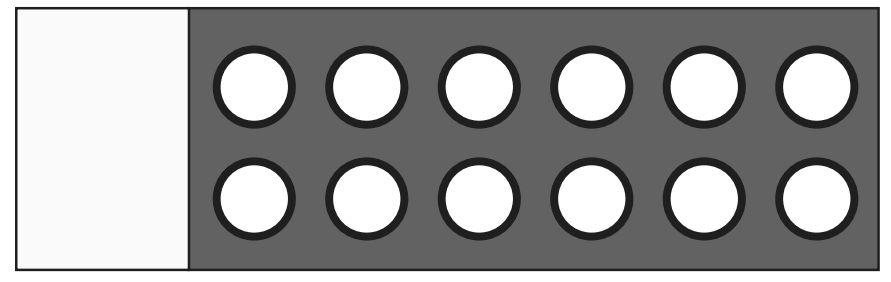

Figura 4.5. Lâmina de Vidro Revestida com Teflon Utilizada na Técnica de FISH.

Posteriormente, as amostras mantidas em 50\% de etanol/PBS (1x) foram homogeneizadas em agitador de tubos por 1 minuto. Com auxílio de pipeta automática, uma alíquota de $1 \mu \mathrm{L}$ de cada amostra foi espalhada sobre o respectivo pocinho da lâmina de vidro, a qual foi subseqüentemente colocada em forno de hibridação a $45^{\circ} \mathrm{C}$, durante 20 minutos, para aumentar a adesão das células sobre a lâmina. Em seguida, as amostras foram desidratadas em séries gradativas de etanol $50 \%, 80 \%$ e $100 \%$, durante 3 minutos cada.

Após a desidratação, as amostras foram cobertas com $9 \mu \mathrm{L}$ de tampão de hibridação pré-aquecido em temperatura específica e $1 \mu \mathrm{L}$ de sonda. As composições dos tampões de hibridação, de lavagem e as respectivas temperaturas de hibridação para cada sonda utilizada seguiram o protocolo descrito na Tabela 4.3.

Após a hibridação, a lâmina com as amostras foi mergulhada e mantida em tubo Falcon contendo $50 \mathrm{~mL}$ do respectivo tampão de lavagem. As temperaturas e tempos de lavagem específicos estão apresentados na Tabela 4.3. Posteriormente, as lâminas foram lavadas com água destilada, para remoção dos sais, e secadas a temperatura ambiente e na ausência de luz.

Para a contagem total de células, as amostras foram coradas com $8 \mu \mathrm{L}$, por pocinho, de solução DAPI (4',6-diamidino-2-fenil indol), $10 \mu \mathrm{g} / \mathrm{mL}$, durante 10 minutos, em temperatura ambiente e na ausência de luz. Em seguida a lâmina foi lavada com água destilada para remover o excesso do corante DAPI e foram aplicados 1,4 $\mu \mathrm{L}$ de glicerol/PBS $(80 / 20 \mathrm{v} / \mathrm{v})$ em cada pocinho, os quais foram subseqüentemente cobertos por lamínulas para serem observados em microscópio de 
fluorescência LEICA DMLB, usando filtros específicos para DAPI e rodamina. As imagens foram fotografadas e congeladas com sistema de câmera de vídeo digital Optronics com tempos de exposição entre 0,5 e 4,0 segundos para epifluorescência.

Para a contagem das células, duas imagens foram congeladas e fotografadas, em mesmo campo microscópico, uma correspondente a excitação do DAPI, referente ao total de células, e a outra correspondente a excitação da rodamina, referente as células hibridadas com as sondas específicas. Antes da contagem, as duas imagens foram sobrepostas para confirmar se as partículas coradas com rodamina eram realmente células hibridadas, ou seja, se correspondiam às células coradas com DAPI.

Para cada sonda e amostra foram contadas entre 800 e 1000 células coradas com DAPI em 20 a 25 campos microscópicos aleatórios. A porcentagem de células hibridadas com as sondas específicas, em cada campo microscópico, foi calculada em relação ao total de células coradas com DAPI.

Os microrganismos aderidos em PU e CV nos ASBBR's tratando água residuária sintética com relação $\mathrm{DQO} /\left[\mathrm{SO}_{4}{ }^{2-}\right]$ igual a 3,2 foram avaliados e caracterizados por FISH em trabalho de mestrado realizado por HIRASAWA (2003).

As análises de $\mathrm{pH}, \mathrm{ORP},\left[\mathrm{SO}_{4}{ }^{2-}\right],[\mathrm{ST}]$, DQO e STV, foram realizadas em conformidade com os métodos $4500-\mathrm{H}^{+}, 2580$, 4500-Sulfate, 4500-Sulfide, 5220, e 2540, respectivamente (APHA, 1998). AT e AB foram determinadas conforme metodologia adaptada por RYPLEY et al. (1986) da original de DILLALO \& ALBERTSON (1961) e ATV foram determinados de acordo com a metodologia descrita por DILLALO \& ALBERTSON (1961). A concentração de ácidos voláteis, Hac em particular, foi obtida por cromatografia gasosa, utilizando-se cromatógrafo a gás HP 6890 equipado com detector de ionização de chama e coluna HP INNOWAX, $30 \mathrm{~m} \times 0,25 \mathrm{~mm} \times 0,25 \mu \mathrm{m}$ de espessura de filme, e hidrogênio superseco como gás de arraste num fluxo de 2,0 mL.min ${ }^{-1}$, (MORAES et al., 2000). Os exames microbiológicos foram realizados conforme descrito no item 3.1.5. Os gases foram analisados por cromatografia gasosa, utilizando-se cromatógrafo marca Gow-Mac equipado com detector de condutividade térmica (série 150) e coluna "Porapack-Q" (comprimento de 2 metros, e diâmetro interno de 1/4 pol - 80/100 mesh), utilizando hidrogênio superseco como gás de arraste a vazão de $1 \mathrm{~mL} \cdot \mathrm{s}^{-1}$. Para 
detecção de $\mathrm{H}_{2} \mathrm{~S}$ utilizou-se medidor de gases com células eletroquímicas marca Testo $^{\circledR}$.

Tabela 4. 3. Protocolos de hibridação.

\begin{tabular}{|c|c|c|c|c|}
\hline Sondas & $\begin{array}{l}\text { Temperatura } \\
\text { de hibridação }\end{array}$ & Tampão de hibridação & $\begin{array}{c}\text { Tempera- } \\
\text { tura e } \\
\text { tempo de } \\
\text { lavagem }\end{array}$ & Tampão de lavagem \\
\hline NON338 & $\begin{array}{l}46^{\circ} \mathrm{C} \text { por } 1,5 \mathrm{~h} \\
\text { câmara úmida }\end{array}$ & $\begin{array}{l}0,9 \mathrm{M} \mathrm{NaCl}, 20 \mathrm{mM} \text { Tris-HCl, } 10 \mathrm{mM} \\
\text { EDTA, } 0,01 \% \text { SDS }(\mathrm{pH} 7,2)+20 \% \\
\text { formamida }\end{array}$ & $\begin{array}{l}48^{\circ} \mathrm{C} \text { por } \\
15 \text { minutos }\end{array}$ & $\begin{array}{l}20 \mathrm{mM} \text { Tris-HCl, } 10 \mathrm{mM} \text { EDTA, } \\
0,01 \% \text { SDS }(\mathrm{pH} 7,2)+225 \mathrm{mM} \\
\mathrm{NaCl}\end{array}$ \\
\hline EUB338 & $\begin{array}{l}46^{\circ} \mathrm{C} \text { por } 1,5 \mathrm{~h} \\
\text { câmara úmida }\end{array}$ & $\begin{array}{l}0,9 \mathrm{M} \mathrm{NaCl}, 20 \mathrm{mM} \text { Tris-HCl, } 10 \mathrm{mM} \\
\text { EDTA, } 0,01 \% \mathrm{SDS}(\mathrm{pH} 7,2)+20 \% \\
\text { formamida }\end{array}$ & $\begin{array}{l}48^{\circ} \mathrm{C} \text { por } \\
15 \text { minutos }\end{array}$ & $\begin{array}{l}20 \mathrm{mM} \text { Tris-HCl, } 10 \mathrm{mM} \text { EDTA, } \\
0,01 \% \text { SDS }(\mathrm{pH} 7,2)+225 \mathrm{mM} \\
\mathrm{NaCl}\end{array}$ \\
\hline SRB385 & $\begin{array}{l}45^{\circ} \mathrm{C} \text { por } 2,0 \mathrm{~h} \\
\text { câmara úmida }\end{array}$ & $\begin{array}{l}0,9 \mathrm{M} \mathrm{NaCl}, 20 \mathrm{mM} \text { Tris-HCl, } 10 \mathrm{mM} \\
\text { EDTA, } 0,01 \% \mathrm{SDS}(\mathrm{pH} 7,2)+30 \% \\
\text { formamida }\end{array}$ & $\begin{array}{l}48^{\circ} \mathrm{C} \text { por } \\
20 \text { minutos }\end{array}$ & $\begin{array}{l}20 \mathrm{mM} \text { Tris-HCl, } 10 \mathrm{mM} \text { EDTA, } \\
0,01 \% \text { SDS }(\mathrm{pH} 7,2)+80 \mathrm{mM} \\
\mathrm{NaCl}\end{array}$ \\
\hline ARC915 & $\begin{array}{l}45^{\circ} \mathrm{C} \text { por } 2,0 \mathrm{~h} \\
\text { câmara úmida }\end{array}$ & $\begin{array}{l}0,9 \mathrm{M} \mathrm{NaCl}, 20 \mathrm{mM} \text { Tris-HCl, } 10 \mathrm{mM} \\
\text { EDTA, } 0,01 \% \text { SDS }(\mathrm{pH} 7,2)+20 \% \\
\text { formamida }\end{array}$ & $\begin{array}{l}48^{\circ} \mathrm{C} \text { por } \\
20 \text { minutos }\end{array}$ & $\begin{array}{l}20 \mathrm{mM} \text { Tris-HCl, } 10 \mathrm{mM} \text { EDTA, } \\
0,01 \% \text { SDS }(\mathrm{pH} 7,2)+225 \mathrm{mM} \\
\mathrm{NaCl}\end{array}$ \\
\hline
\end{tabular}

Fonte: Raskin et al. (1994), Domingues (2004).

\subsubsection{Ensaio Hidrodinâmico}

O comportamento hidrodinâmico dos reatores foi avaliado através do teste de estímulo-resposta ao pulso utilizando-se, opcionalmente, ácido sulfúrico diluído (1 M) como traçador e monitorando-se o pH em função do tempo. Os reatores contendo os MS foram carregados com água, e o teste foi realizado para freqüências de agitação de 90, 180, 300, 500 e $800 \mathrm{rpm}$. Os dados foram obtidos por um medidor digital de $\mathrm{pH}$ e íons Orion- $920 \mathrm{~A}^{\circledR}$ e depois armazenados em software Orion DataColect $^{\circledR}$, sendo posteriormente tratados com o uso do software Microcal Origin $6.0^{\circledR}$, 
para ajuste de modelo matemático e cálculo do tempo de mistura $\left(t_{M}\right)$. Com base nos resultados desse estudo, definiu-se a freqüência de agitação a ser empregada nos reatores

Os valores do $\mathrm{pH}$ em resposta ao pulso com $\mathrm{H}_{2} \mathrm{SO}_{4} 1 \mathrm{M}$ para cada freqüência de agitação foram normalizados e plotados em função do tempo.

\subsubsection{Avaliação do Desempenho dos ASBBR's no Tratamento de Água Residuária $\underline{\text { Sintética com Relações DQO/SO }}{ }_{4}{ }^{2-}$ de $3,2,1,3$, e 0,4 .}

Os ASBBR's foram operados em ciclos de $24 \mathrm{~h}$, compreendendo as etapas de enchimento, reação e descarga. As etapas de enchimento e descarga foram realizadas com tempo de duração de 12 minutos, para cada operação. O funcionamento das bombas dosadoras foi controlado por temporizadores previamente programados. A freqüência de agitação de $300 \mathrm{rpm}$ foi estabelecida com base no estudo do comportamento hidrodinâmico dos reatores descrito anteriormente.

A água residuária era preparada em recipiente de plástico e mantida a $5^{\circ} \mathrm{C} \mathrm{em}$ refrigerador para minimizar as reações bioquímicas fora dos reatores. A distância entre o reservatório no refrigerador e o reator era aproximadamente 3 metros. A linha de alimentação foi constituída de mangueira de polietileno com diâmetro interno de 9 $\mathrm{mm}$. O volume de meio retido na linha de alimentação, fora do refrigerador, foi de aproximadamente $270 \mathrm{~mL}$ (5\% do volume útil dos reatores). Dessa forma, a atividade microbiana nesse trecho foi considerada desprezível.

\subsubsection{Estratégia de Inoculação}

O inóculo foi incorporado ao substrato durante 30 dias, em quantidade suficiente para resultar em concentração de STV em torno de $300 \mathrm{mg} . \mathrm{L}^{-1}$. Durante essa operação, adicionava-se diariamente o lodo macerado no reservatório de substrato e acionava-se manualmente a bomba de alimentação. Após esse período, matrizes de $\mathrm{PU}$ e $\mathrm{CV}$ foram retiradas, para exames microbiológicos e determinação de STV. Posteriormente, os reatores passaram a ser alimentados automaticamente com água residuária sintética sem adição de biomassa. Essa estratégia de inoculação foi adotada porque o material suporte dos reatores era renovado a cada início de operação, quando era alterada a concentração de sulfato da água residuária. Embora exista um protocolo de inoculação de matrizes de espuma de poliuretano, descrito 
por ZAIAT et al. (1994), este não se aplica ao carvão vegetal. Como o objetivo deste trabalho foi comparar o desempenho de reatores preenchidos com diferentes tipos de material suporte o procedimento de inoculação teve que ser igual para ambos.

Para captação e estimativa do volume de biogás que "escapava" juntamente com o efluente dos ASBBR's adaptou-se um reservatório de 10 Litros selado com rolha de borracha, com entrada para o efluente dos reatores e saída de biogás conectada a um sistema de medição de volume por deslocamento de líquido (Figura 4.6). Do volume total de água deslocado descontava-se o volume de efluente dos ASBBR's contido no reservatório obtendo-se, indiretamente, o volume estimado de biogás.

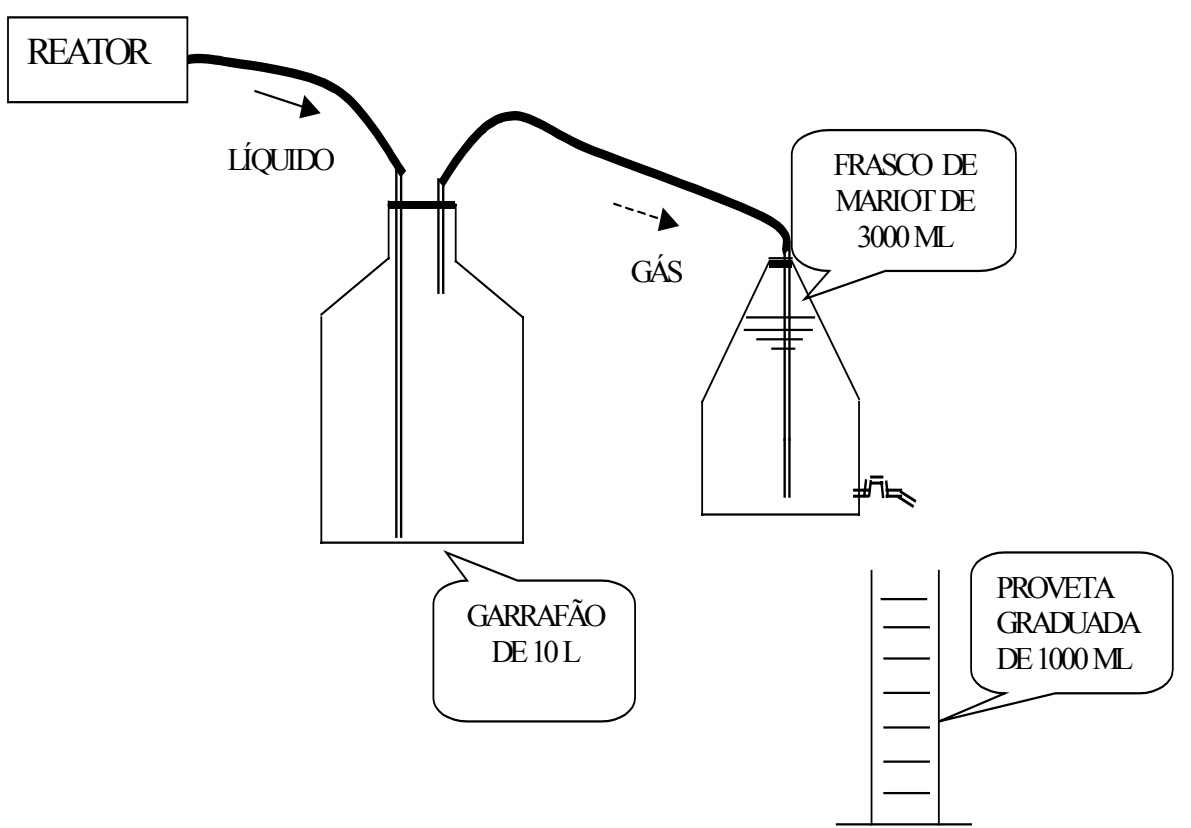

Figura 4.6. Aparato para Captação e Medição de Volume dos Gases dos ASBBR.

\subsubsection{Obtenção de Parâmetros Cinéticos de Consumo de Substratos Orgânicos} pelas Bactérias Acidogênicas (BA), Bactérias Redutoras de Sulfato (BRS) e Arqueas Metanogênicas (AM)

Quando os reatores apresentaram estabilidade em remoção de sulfato, realizou-se o perfil temporal dos parâmetros DQO, $\left[\mathrm{SO}_{4}{ }^{2-}\right]$ e ácidos voláteis, para posterior avaliação da cinética de utilização de substrato por BRS, BA e AM. As velocidades de consumo de matéria orgânica e de compostos intermediários da 
digestão anaeróbia por esses microrganismos foram determinadas e avaliadas nas três situações de relação $\mathrm{DQO} /\left[\mathrm{SO}_{4}{ }^{2-}\right]$.

\subsubsection{Avaliação do Efeito de Etanol Sobre o Processo de Biodessulfatação.}

O efeito de etanol sobre o processo de biodessulfatação foi avaliado, assim como a via de utilização dessa substância pelas BRS. Essa etapa foi realizada para obter parâmetros que conduzissem à otimização da dosagem de etanol quando este for opcionalmente adicionado em águas residuárias deficientes em doadores de elétrons e fonte de carbono, e a finalidade do tratamento for a remoção de sulfato.

Inicialmente, os ASBBRs contendo PU e CV como MS foram alimentados com água residuária sintética, preparada com relação DQO/[ $\left[\mathrm{SO}_{4}{ }^{2-}\right]$ igual a 0,4 . Essa foi a condição mais desfavorável observada para o processo de biodessulfatação, nesse trabalho, sem a adição de fonte externa de carbono e doador de elétrons. Dessa forma, quando a $\left[\mathrm{SO}_{4}{ }^{2-}\right]$ no efluente dos reatores não variou significativamente, etanol passou a ser adicionado na água residuária sintética em quantidade estequiométrica (equação 4.1). O procedimento de alimentação ocorreu como descrito no item 4.2.7.

Nessa etapa experimental os reatores não foram inoculados, ou seja, a biomassa que se desenvolveu durante o tratamento de água residuária sintética com relação $\mathrm{DQO} /\left[\mathrm{SO}_{4}{ }^{2-}\right]$ de 3,2 foi mantida em cada reator, seguindo-se apenas o período de adaptação à água residuária sintética com relação $\mathrm{DQO} /\left[\mathrm{SO}_{4}{ }^{2-}\right]$ de 0,4 .

Quando os reatores apresentaram condição de estabilidade em redução de sulfato da água residuária sintética contendo etanol, realizou-se o perfil temporal dos parâmetros DQO, $\left[\mathrm{SO}_{4}{ }^{2-}\right]$, ácidos voláteis para obtenção de parâmetros cinéticos após ajuste de modelo.

\subsubsection{Modelação Cinética}

Com o intuito de identificar as principais rotas de consumo de substratos orgânicos que ocorreram nos ASBBR's, nesse trabalho, propôs-se um modelo cinético envolvendo reações de primeira e segunda ordens. O modelo foi baseado no diagrama adaptado por COLLERAN et al. (1995) que representa a degradação de moléculas poliméricas em ambiente anaeróbio e com presença de sulfato. De acordo com o diagrama adaptado (Figura 4.7), as BRS competem com BA por 
intermediários da digestão anaeróbia de matéria orgânica (succinato, propionato, piruvato, etc), competem com BA e AM por hidrogênio e com AM acetoclásticas por ácido acético. Além disso, ocorre competição interespécies de BRS por intermediários de fermentação, pois existem espécies que oxidam parcialmente e outras que têm a capacidade de oxidar completamente esses compostos (COLLERAN et al., 1995).

Inicialmente, o modelo cinético foi estabelecido considerando duas vias principais de degradação da matéria orgânica: uma via acetogênica, representada pelo metabolismo de BRS e BA produtoras de ácido acético; e uma via nãoacetogênica que corresponde à oxidação direta dos compostos monoméricos envolvendo BA, BRS e AM hidrogenotróficas. Na via acetogênica considerou-se que BRS competem com BA por compostos orgânicos monoméricos e por intermediários de fermentação (butirato, propionato, succinato, etc) e com as AM acetoclásticas por acetato. Na via não-acetogênica considerou-se a competição entre BRS e BA por compostos orgânicos monoméricos e intermediários de fermentação, e com AM por hidrogênio.

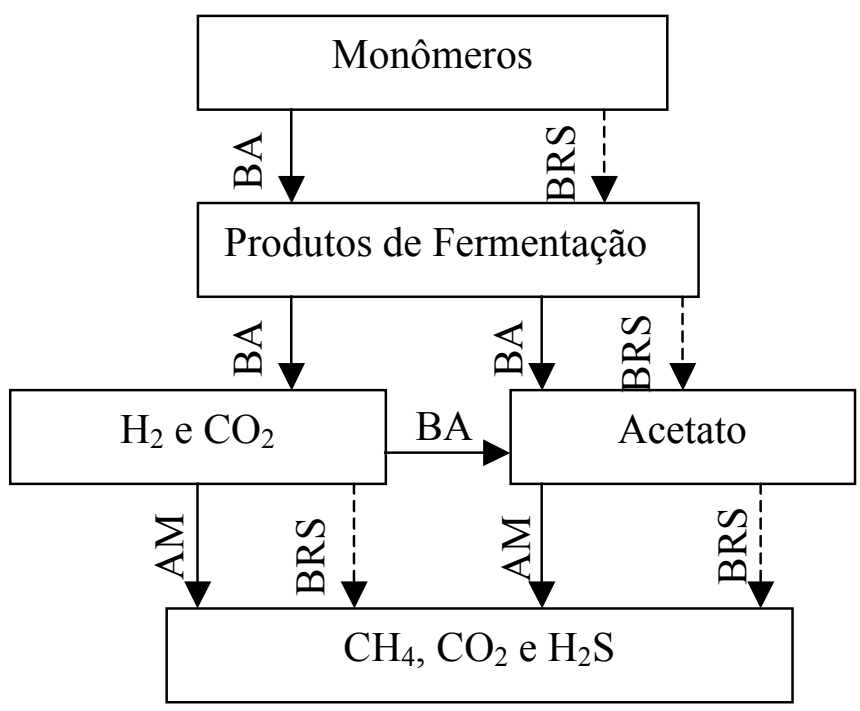

Figura 4.7. Rota de Degradação de Compostos Orgânicos Monoméricos em Ambiente Anaeróbio com Presença de Sulfato (Adaptado de COLLERAN, 1995). 


\subsection{Oxidação Parcial do Sulfeto em Reator Aeróbio}

O efluente de um ASBBR sulfetogênico foi tratado num reator aeróbio operado em bateladas seqüenciais (SBBR) sob baixa concentração de OD (entre 0,1 e 0,5 mg. $\mathrm{L}^{-1}$ ) para promover a oxidação parcial do sulfeto a enxofre por microrganismos. Os dois reatores continham biomassa imobilizada em PU.

A configuração do SBBR foi idêntica a do ASBBR, contendo pedra porosa adaptada à mangueira de polietileno que foi conectada a um pequeno compressor de ar, do tipo utilizado em aquários que funcionava intermitentemente, acionado e desligado por temporizador. A vazão de ar aplicada no SBBR era controlada por válvula de plástico utilizada em aquários. Os reatores ASBBR e SBBR foram operados em ciclos de 24 horas compreendidos pelas etapas: enchimento (12 min), reação $(23,6$ h) e descarga (12 min).

Decidiu-se não inocular o SBBR em virtude da presença de morfologias semelhantes a microrganismos que oxidam sulfeto a enxofre elementar no efluente do ASBBR, observadas por microscopia ótica. Dessa forma, condições físicas e químicas adequadas para o cultivo dessas espécies microbianas foram estabelecidas.

Estavam previstas diluições do efluente do reator sulfetogênico para que fosse minimizado o efeito da toxicidade do sulfeto. Todavia, observações microscópicas e a existência de enxofre na superfície do reator sulfetogênico conduziram à partida do SBBR com o efluente do ASBBR sem diluição. Dessa forma a saída do ASBBR foi conectada na entrada do SBBR por mangueira de polietileno com diâmetro interno de $9 \mathrm{~mm}$. O efluente do SBBR era acondicionado em recipiente de plástico para posterior descarte.

As principais variáveis monitoradas durante a operação desse sistema foram: $\mathrm{pH}, \mathrm{DQO}, \mathrm{OD}, \mathrm{ORP},\left[\mathrm{SO}_{4}{ }^{2-}\right]$ e [ST]. Enxofre elementar presente no lodo retido pelo material suporte foi analisado por EDXRF (Fluorescência de Raios-X com Dispersão de Energia) no IQSC/USP. 


\section{RESULTADOS E DISCUSSÃO}

\subsection{Ensaio de Imobilização de Biomassa em Suportes Inertes}

\subsubsection{Resultados das Análises Físico-Químicas}

$\mathrm{Na}$ primeira etapa dessa fase do trabalho, a DQO e a $\left[\mathrm{SO}_{4}{ }^{2-}\right]$ na água residuária sintética foram: $1.234 \pm 282 \mathrm{mg} \cdot \mathrm{L}^{-1} \mathrm{e} 1.375 \pm 260 \mathrm{mg} \cdot \mathrm{L}^{-1}$, respectivamente, resultando em relação $\mathrm{DQO} /\left[\mathrm{SO}_{4}{ }^{2-}\right]$ de 0,9 . Após 7 dias de operação em regime de batelada seqüencial com ciclos de 24 horas, os reatores com PU, CV e CE, apresentaram eficiências em remoção de DQO acima de 85\%. Nos reatores com PE, eficiência superior a $85 \%$ foi obtida somente a partir do $14^{\circ}$ dia de operação. As eficiências em remoção de DQO durante os ciclos operacionais nos sistemas com PU, CV, CE e PE foram 86\% ( $\pm 3 \%), 90 \%( \pm 3 \%), 86 \%( \pm 4 \%)$ e $84 \%$ $( \pm 9 \%)$, respectivamente. A Tabela 5.1 mostra os valores de DQO determinados ao final das bateladas nos dias de coleta das amostras de MS colonizado.

Tabela 5.1. Valores de DQO obtidos ao final das bateladas. Os valores das eficiências em remoção de DQO (\%) são apresentados entre parênteses.

\begin{tabular}{ccccc}
\hline Tempo $(\mathrm{d})$ & PU & CV & CE & PE \\
\hline 7 & $179(85 \%)$ & $122(90 \%)$ & $154(88 \%)$ & $225(82 \%)$ \\
14 & $140(89 \%)$ & $110(91 \%)$ & $130(89 \%)$ & $174(86 \%)$ \\
21 & $151(88 \%)$ & $101(92 \%)$ & $122(90 \%)$ & $123(90 \%)$ \\
28 & $215(83 \%)$ & $164(87 \%)$ & $269(78 \%)$ & $180(85 \%)$ \\
\hline
\end{tabular}

Redução de sulfato somente foi observada no $28^{\circ}$ dia, somente nos reatores com PU e CV, com eficiências de 39\% e 45\%, respectivamente, como mostra a Tabela 5.2.

Redução de sulfato ocorrendo em reatores contendo células imobilizadas em espuma de poliuretano foi observada em trabalhos anteriores realizados no Laboratório de Processos Biológicos da EESC (CADAVID et al., 1999, SILVA et al. 
2002 e VELA et al., 2002). Apesar das diferenças entre as características das águas residuárias estudadas, em todos os trabalhos esse material demonstrou ser um bom suporte para imobilizar BRS.

O fato da redução de sulfato ter sido evidenciada somente no $28^{\mathrm{o}}$ dia pode ser devido às condições de inoculação e alimentação dos reatores, uma vez que os microrganismos foram adaptados ao substrato durante os ciclos operacionais.

Durante a fase experimental, não foi observada redução de sulfato nos reatores contendo $\mathrm{CE}$ e PE.

Tabela 5.2. Concentrações de Sulfato no Efluente dos Reatores Diferenciais.

\begin{tabular}{ccccc}
\hline Tempo (d) & PU & CV & CE & PE \\
\hline 7 & 1120 & 1060 & 1550 & 1600 \\
14 & 1600 & 1600 & 1550 & 1600 \\
21 & 1600 & 1650 & n.a. & n.a. \\
28 & 850 & 800 & 1600 & 1650 \\
\hline \multicolumn{5}{c}{ n.a. - Não Analisado }
\end{tabular}

A Figura 5.1 representa a adesão de microrganismos (quantificada como $\mathrm{SSV}$ ) em PU, e a Figura $5.2 \mathrm{em} \mathrm{CV}, \mathrm{CE}$ e $\mathrm{PE}$ ao longo do experimento. Os resultados indicam que as matrizes de PU apresentaram a melhor adesão específica de biomassa (120-872 mg SSV.g $\left.{ }^{-1} \mathrm{MS}\right)$, seguida por CV (56-84 mg SSV.g $\left.{ }^{-1} \mathrm{MS}\right), \mathrm{CE}$ (22-47 mg SSV.g $\left.{ }^{-1} \mathrm{MS}\right)$ e PE (2-23 mg SSV.g $\left.{ }^{-1} \mathrm{MS}\right)$. Entretanto, os reatores com CV e CE apresentaram a maior retenção absoluta de biomassa (Figura 5.3), atingindo 21 e $25 \mathrm{mg} \mathrm{SSV} \cdot \mathrm{mL}^{-1}$ em CE e CV, respectivamente, no $28^{\circ}$ dia de operação. No mesmo período, a concentração absoluta de biomassa foi cerca de $10 \mathrm{mg} \mathrm{SSV} \cdot \mathrm{mL}^{-1}$ para os suportes poliméricos. A adesão de microrganismos em carvão foi favorecida, provavelmente, pelas características físicas e químicas da superfície desse material, principalmente, pela porosidade e capacidade de adsorção. 


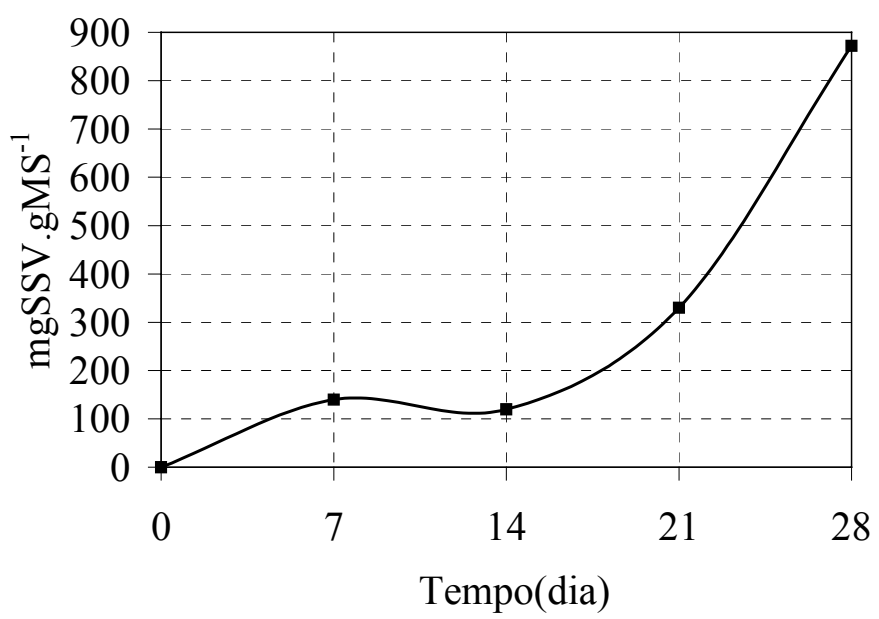

Figura 5.1. Concentração de Biomassa Aderida por mg de PU (Concentração Específica) nos Reatores Diferenciais.

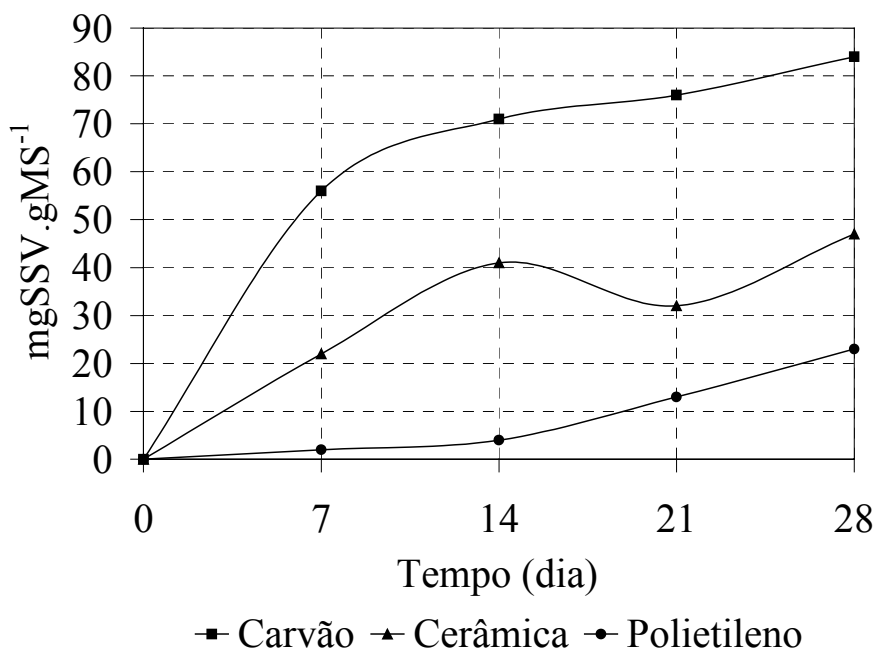

Figura 5.2. Concentração Específica de Biomassa em: (a) CV, (b) CE e, (c) PE nos Reatores Diferenciais. 


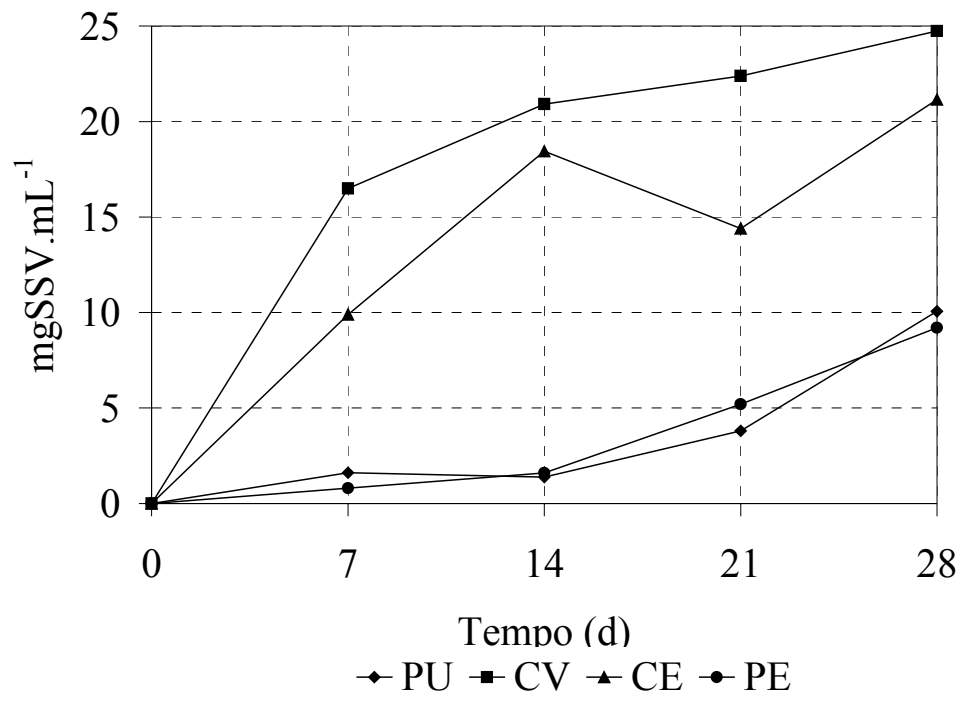

Figura 5.3. Concentração Absoluta de Biomassa (STV) nos Reatores Diferenciais.

\subsubsection{Resultados dos Exames Microbiológicos}

\subsubsection{Inóculo}

A Tabela 5.3 apresenta as formas morfológicas observadas no inóculo, por microscopia ótica e suas respectivas freqüências.

O lodo utilizado como inóculo apresentou grande diversidade de microrganismos, incluindo morfologias semelhantes a BRS e AM (Figura 5.4), comprovado pelos resultados obtidos por FISH. A Figura 5.5 expressa as porcentagens relativas de células pertencentes ao Domínio Bacteria (EUB338), grupo BRS (SRB385) e Domínio Archaea (ARC915) e, as barras de erros indicam os desvios padrões. 
Tabela 5. 3. Caracterização Morfológica do Inóculo por Microscopia Ótica

\begin{tabular}{ll}
\hline \multicolumn{1}{c}{ MORFOLOGIAS } & FREQÜENCIA OBSEVADA \\
\hline Arqueas Metanogênicas & ++ \\
Methanosarcina sp. & ++++ \\
Methanosaeta sp. & ++++ \\
Bacilos Fluorescentes & \\
Bactérias & + \\
Bacilos com extremidades arredondadas & +++ \\
Bacilos curvos (víbrios) & ++++ \\
Bacilos delgados & ++ \\
Bacilos ovalados & + \\
Cocos & ++ \\
Filamentos & + \\
\hline$(+++)$ predomingtes-(++) frequites & \\
\hline
\end{tabular}

$(++++)$ predominantes $-(+++)$ freqüentes $-(++)$ pouco frequentes $-(+)$ raros $-(-)$ não observados
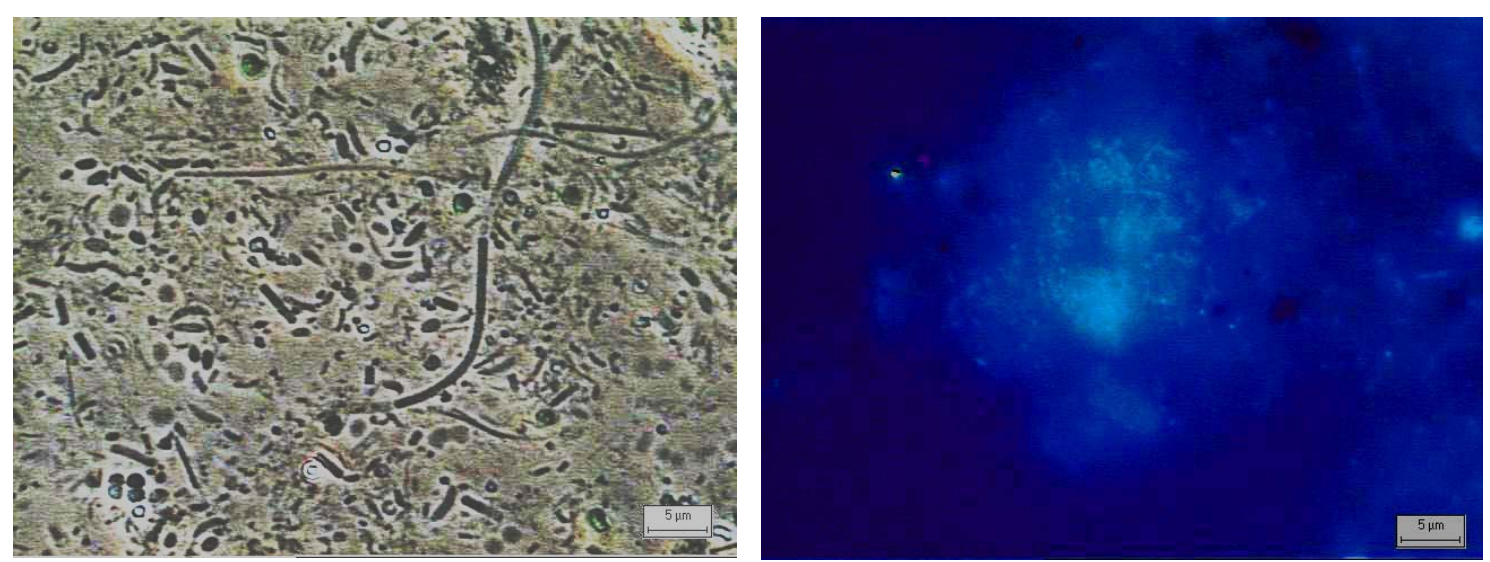

Figura 5.4. Morfologias Observadas por Meio de Microscopia Ótica, Luz Comum e Fluorescência, no Lodo Utilizado como Inóculo. (a) Filamentos Semelhantes a Methanosaeta sp.; (b) Arranjo semelhante a Methanosarcina sp.. 


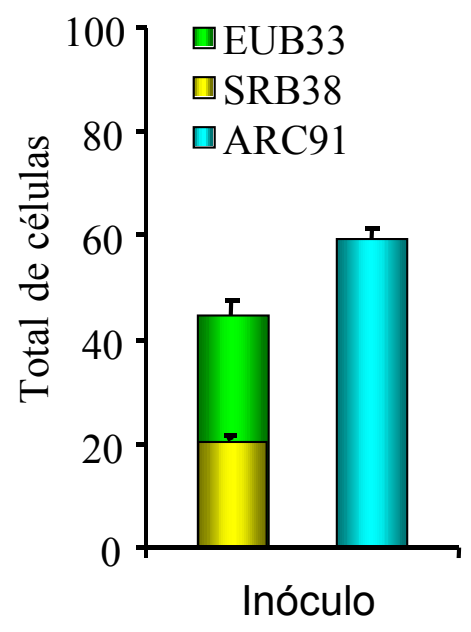

Figura 5.5. Composição da Comunidade Microbiana Determinada por FISH em Amostra do Lodo Utilizado como Inóculo. (HIRASAWA, 2003).

\subsubsection{Espuma de Poliuretano (PU)}

A Tabela 5.4 apresenta as morfologias e suas respectivas freqüências observadas por microscopia ótica na biomassa aderida em PU. Após 7 dias de operação houve predomínio de bacilos com extremidades arredondadas (Figura 5.6). Essas morfologias foram observadas anteriormente em reatores anaeróbios horizontais de leito fixo (RAHLF), cujo material suporte era espuma de poliuretano por TOMMASO (1999) e RIBEIRO (2001) e foram relacionadas, por esses autores, aos processos de hidrólise e fermentação.

Morfologias semelhantes às pertencentes ao grupo I de BRS, que oxidam parcialmente seus substratos orgânicos (MADIGAN et al. 1997), na forma de bacilos curvos e células ovóides, também foram observadas em PU após 7 dias.

Em amostras de PU examinadas após 14 dias (Figura 5.7) foi observado o aparecimento de espiroquetas, provavelmente devido à presença de $\mathrm{H}_{2} \mathrm{~S}$, pois esses microrganismos o utilizam como fonte de enxofre para a síntese de proteínas (MADIGAN et al. 1997) 
Tabela 5.4. Caracterização Morfológicas dos Microrganismos Aderidos em Espuma de Poliuretano

\begin{tabular}{|c|c|c|c|c|}
\hline \multirow[t]{2}{*}{ MORFOLOGIAS } & \multicolumn{4}{|c|}{ FREQÜÊNCIA OBSERVADA } \\
\hline & $7 \mathrm{~d}$ & $14 \mathrm{~d}$ & $21 \mathrm{~d}$ & $28 \mathrm{~d}$ \\
\hline \multicolumn{5}{|l|}{ Arqueas Metanogênicas } \\
\hline - Methanosarcina sp. & ++ & ++++ & +++ & +++ \\
\hline - Methanosaeta sp. & ++ & + & + & +++ \\
\hline - Bacilos Fluorescentes & ++ & + & ++ & ++++ \\
\hline \multicolumn{5}{|l|}{ Bactérias } \\
\hline - Bacilos com extremidades arredondadas & ++++ & ++++ & ++++ & ++++ \\
\hline - Bacilos curvos (víbrios) & +++ & + & +++ & +++ \\
\hline - Bacilos delgados & ++++ & ++++ & ++ & + \\
\hline - Bacilos ovalados & ++ & ++ & ++ & ++ \\
\hline - Bacilos com grânulos & ++ & +++ & +++ & +++ \\
\hline - Cocos isolados & ++ & + & + & + \\
\hline - Cocos em cadeia & ++ & - & + & - \\
\hline - Espiroqueta & - & + & - & - \\
\hline - Filamentos & + & + & + & ++ \\
\hline
\end{tabular}
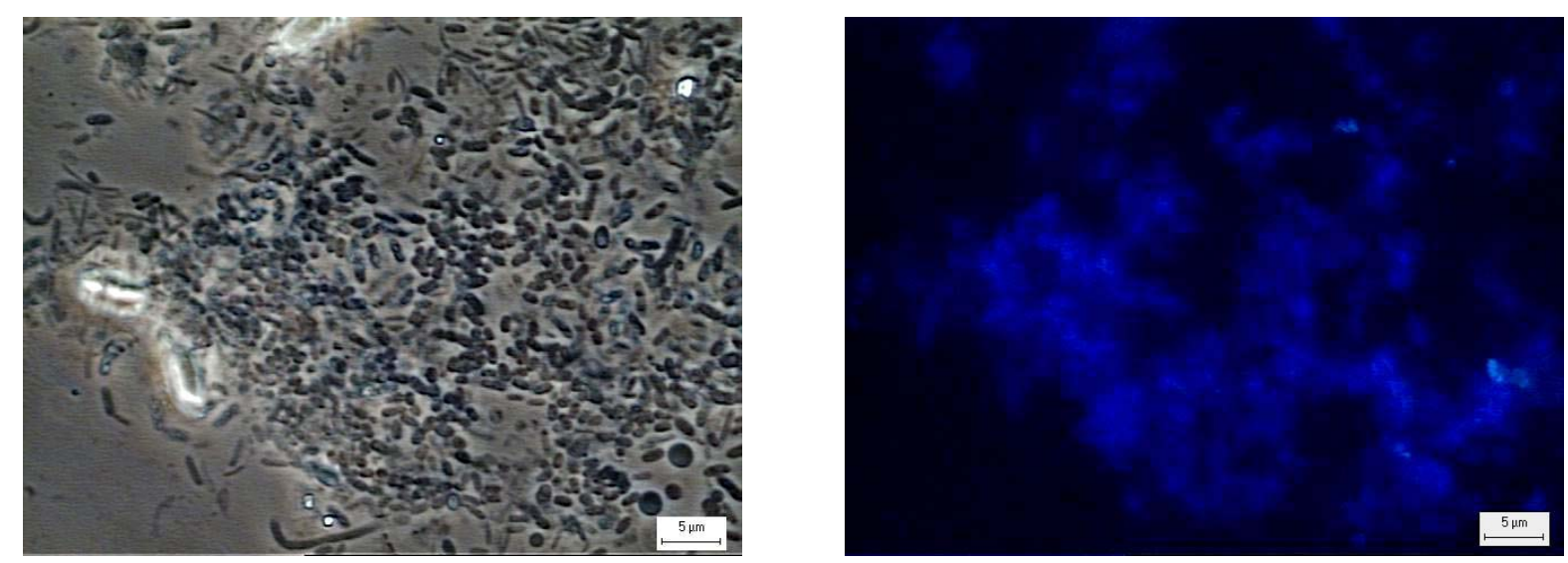

Figura 5.6. Morfologias Observadas por Meio de Microscopia Ótica de Luz Comum e Fluorescência em Matrizes de PU Colonizadas Após 7 Dias de Operação. Bacilos Curtos com Extremidades Arredondadas, Bacilos com Extremidades Afiladas, Víbrios, Cocos e Bacilos Fluorescentes e Cocos Formando Arranjos Semelhantes a Methanosarcina sp.. 

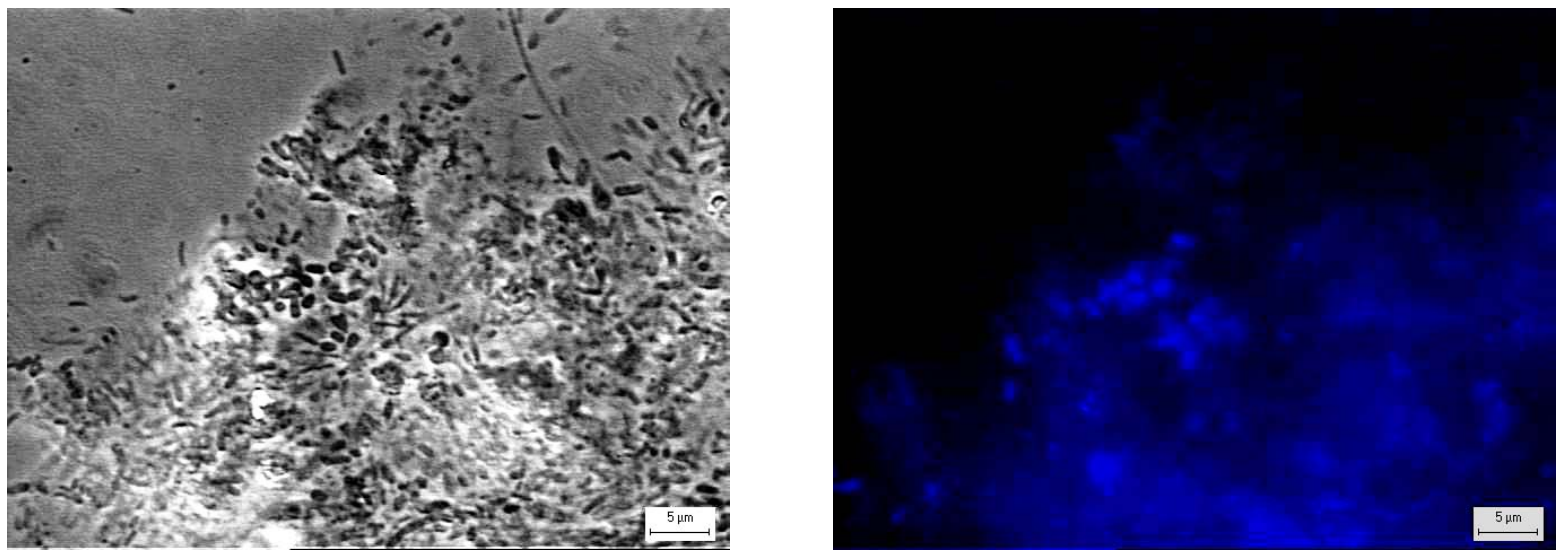

Figura 5.7. Morfologias Observadas por Meio de Microscopia Ótica, Luz Comum e

Fluorescência, em PU Após 14 Dias de Operação. Predomínio de Bacilos com

Extremidades Arredondadas e Presença de Bacilos Fluorescentes.

Foi observada abundância de Methanosaeta sp. nas amostras de PU, examinadas após 21 e 28 dias de operação dos reatores (Figuras 5.8 e 5.9). A presença de acetato produzido pelas BRS oxidadoras incompletas de substratos orgânicos pode ter favorecido o crescimento de Methanosaeta sp., além das propriedades da espuma de poliuretano utilizada como material suporte. PICANÇO et al. (2000), observaram que esses microrganismos aderiram facilmente em espuma de poliuretano. A Figura 5.10 apresenta as morfologias observadas por microscopia eletrônica em amostras de PU colonizadas após 7, 14, 21 e 28 dias.
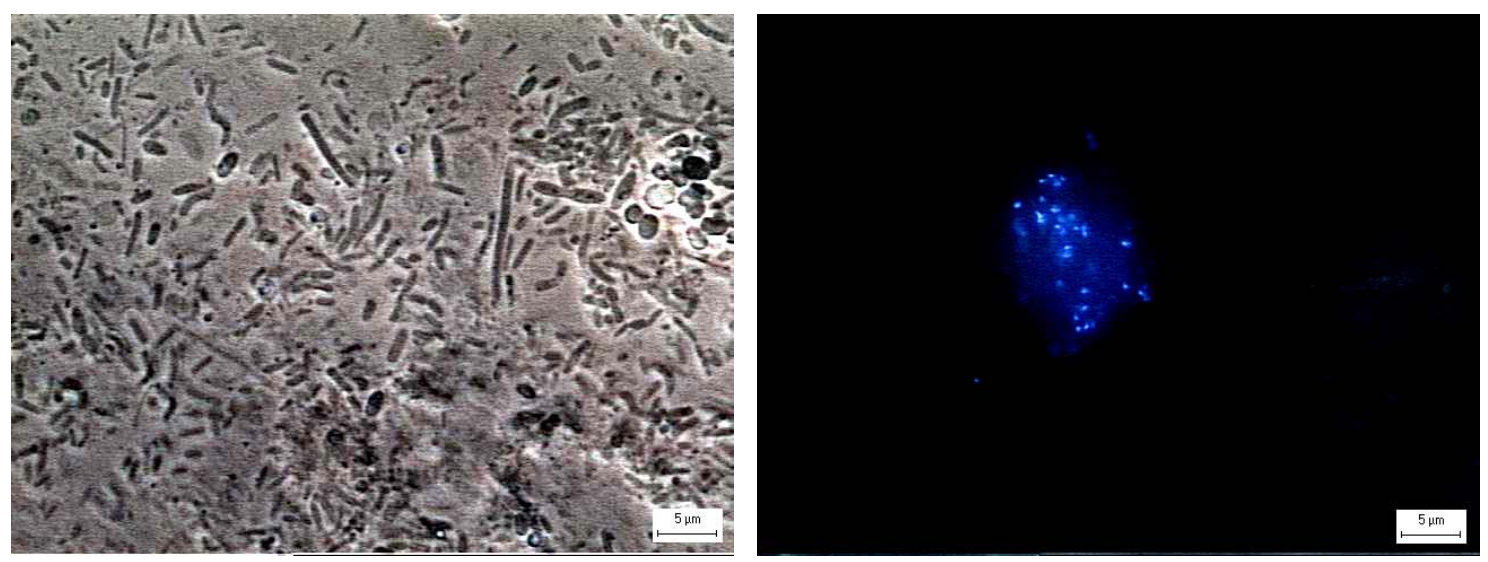

Figura 5.8. Morfologias Observadas por Meio de Microscopia Ótica, Luz Comum e Fluorescência, em Matrizes de PU Após 21 Dias de Operação do Reator. Filamentos Semelhantes a Methanosaeta sp., Bacilos com Extremidades Arredondadas, Víbrios e Bacilos Fluorescentes. 

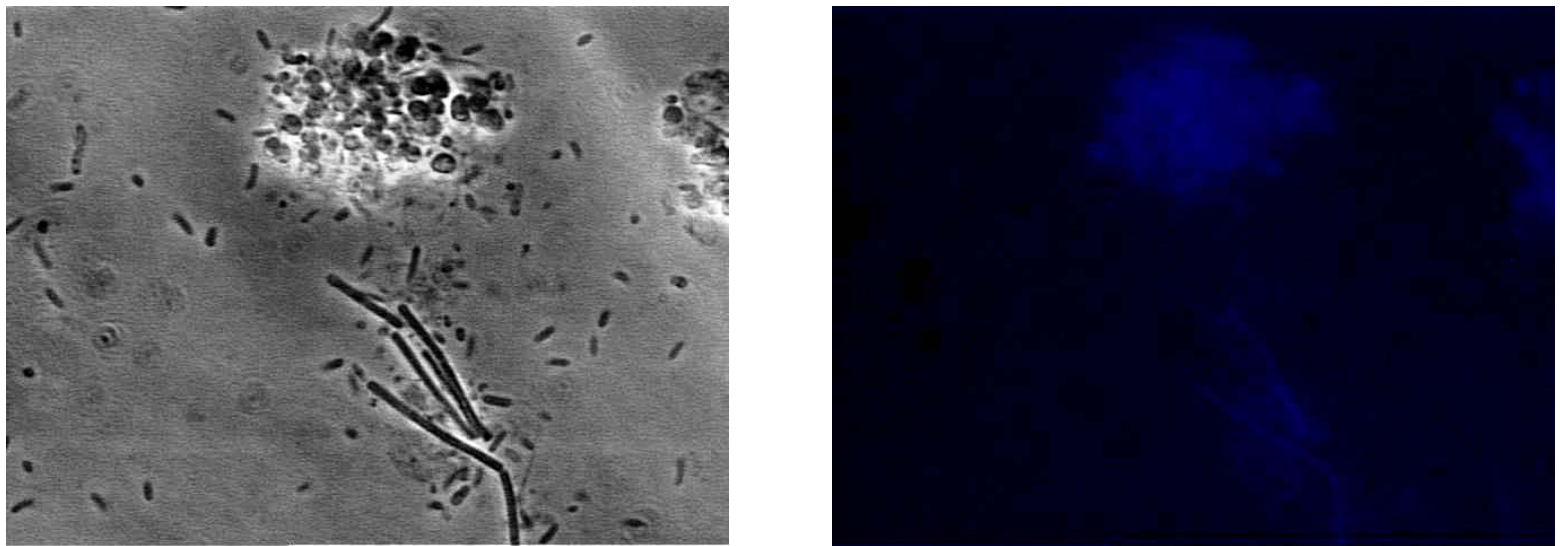

Figura 5.9. Morfologias Observadas por Meio de Microscopia Ótica, Contraste de

Fase e Fluorescência, em Matrizes de PU Após 28 Dias de Operação do Reator.

Filamentos Semelhantes a Methanosaeta sp., Bacilos com Extremidades

Arredondadas e Cocos Formando Arranjos Semelhantes a Methanosarcina sp..

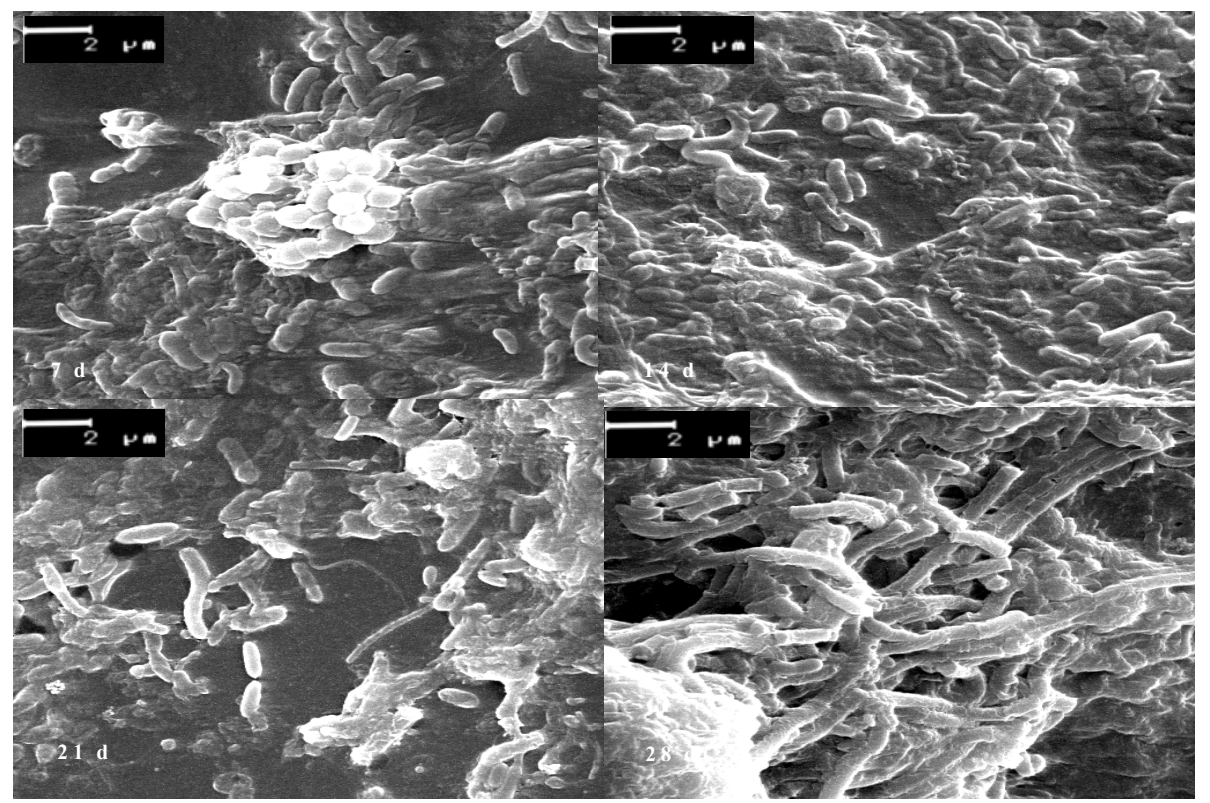

Figura 5.10. Morfologias Observadas em PU. Após 7, 14, 21 e 28 Dias de Operação dos Reatores. Predomínio de Bacilos Curtos, com Extremidades Arredondadas, Presença de Víbrios e Cocos Formando Arranjos Semelhantes a Methanosarcina.sp. e Filamentos Semelhantes a Methanosaeta sp..

A baixa eficiência em redução de sulfato observada no início do experimento, associada com a presença de BRS, indica a possibilidade desses microrganismos ter desempenhado processo fermentativo ao invés de respiração anaeróbia. Todavia, esse 
fenômeno deve ser melhor estudado para a compreensão e domínio do processo sulfetogênico.

\subsubsection{Carvão Vegetal (CV)}

A Tabela 5.5 apresenta as morfologias e suas respectivas freqüências, observadas por microscopia ótica na biomassa aderida em CV. Após 7 dias observou-se a presença de morfologias microbianas relacionadas aos processos de hidrólise e fermentação anaeróbia (Figura 4.11) e após 14 dias, predomínio de células ovóides e cocos em cadeia (Figuras 4.12 a 4.14). A Figura 4.15 apresenta as morfologias aderidas em CV, observadas por MEV.
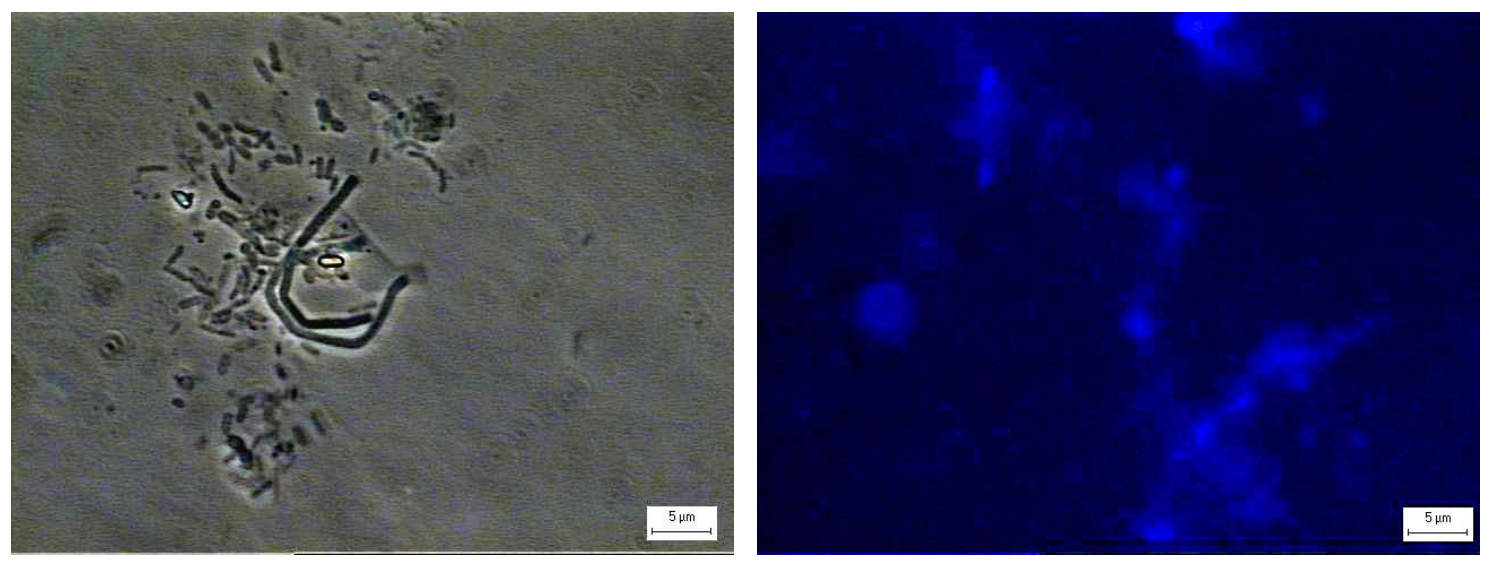

Figura 5.11. Morfologias Observadas por Meio de Microscopia Ótica, Luz Comum e Fluorescência, em Matrizes de CV Após 7 Dias de Operação do Reator. Filamentos Semelhantes a Methanosaeta sp., Bacilos com Extremidades Arredondadas, Células Ovóides, Bacilos Fluorescentes e Arranjos Semelhantes a Methanosarcina sp. . 
Tabela 5.5. Caracterização Morfológica dos Microrganismos Aderidos em CV

\begin{tabular}{|c|c|c|c|c|}
\hline \multirow[t]{2}{*}{ MORFOLOGIAS } & \multicolumn{4}{|c|}{ FREQÜÊNCIA OBSERVADA } \\
\hline & $7 \mathrm{~d}$ & $14 \mathrm{~d}$ & $21 \mathrm{~d}$ & $28 \mathrm{~d}$ \\
\hline \multicolumn{5}{|l|}{ Arqueas Metanogênicas } \\
\hline - Methanosarcina sp. & + & ++ & ++++ & +++ \\
\hline - Methanosaeta sp. & + & + & + & + \\
\hline - Bacilos Fluorescentes & + & ++ & + & ++ \\
\hline \multicolumn{5}{|l|}{ Bactérias } \\
\hline - Bacilos com extremidades arredondadas & ++++ & +++ & ++++ & ++++ \\
\hline - Bacilos curvos (víbrios) & + & + & + & + \\
\hline - Bacilos delgados & ++ & ++ & ++ & ++ \\
\hline - Bacilos ovalados & +++ & ++++ & +++ & +++ \\
\hline - Bacilos com grânulos & +++ & + & ++ & + \\
\hline - Cocos isolados & + & ++ & + & + \\
\hline - Cocos em cadeia & + & - & - & - \\
\hline - Filamentos & + & + & ++ & ++ \\
\hline
\end{tabular}

$(++++)$ predominantes $-(+++)$ freqüentes $-(++)$ pouco frequentes $-(+)$ raros $-(-)$ não observados
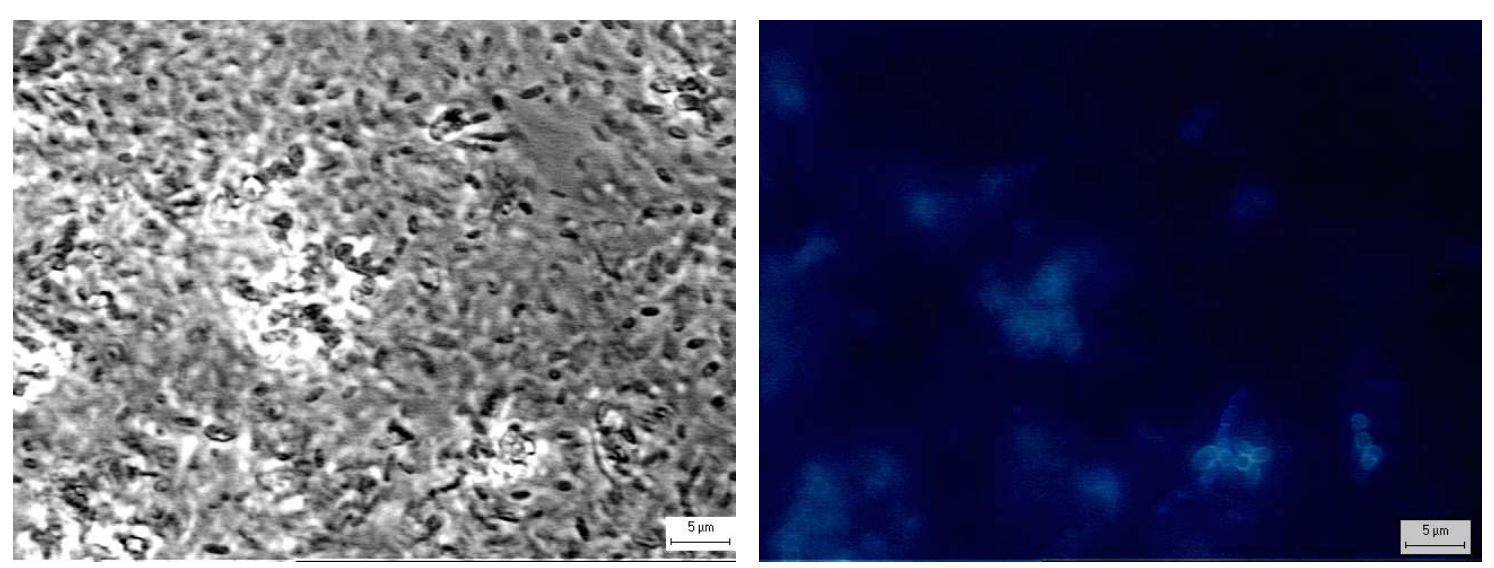

Figura 5.12. Morfologias Observadas por Meio de Microscopia Ótica, Luz Comum e

Fluorescência, em Matrizes de CV Após 14 Dias de Operação do Reator. Bacilos com Extremidades Arredondadas, Células Ovóides, Arranjos Semelhantes a 

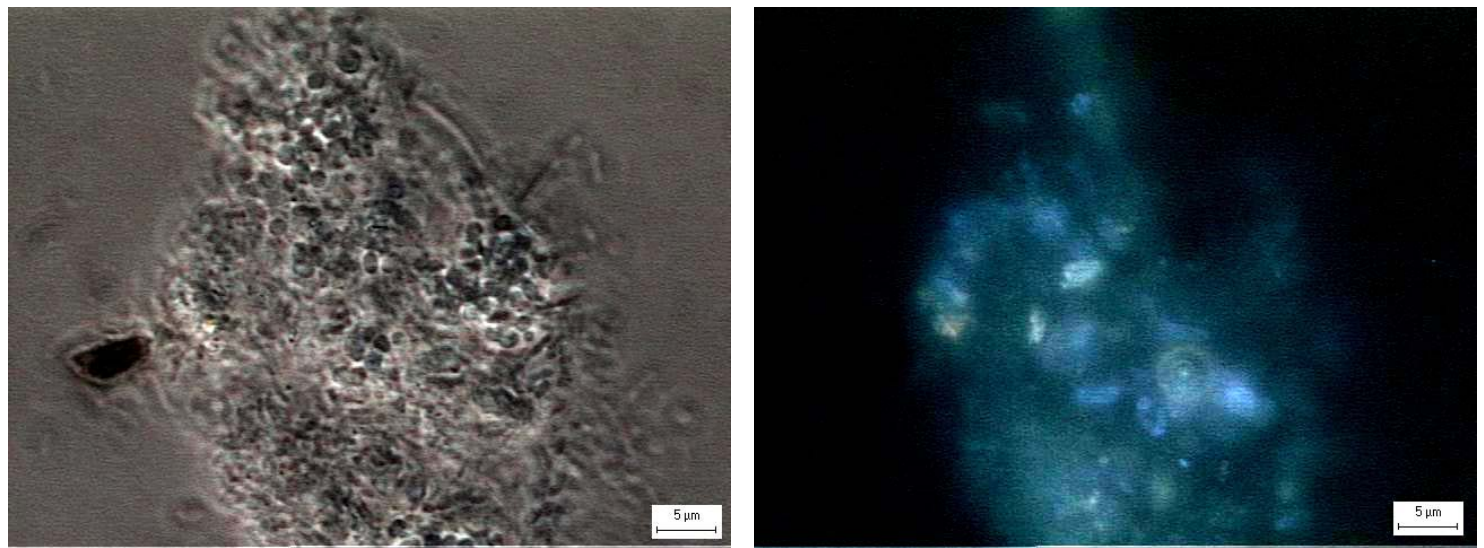

Figura 5.13. Morfologias Observadas por Meio de Microscopia Ótica Utilizando Luz

Comum e com Fluorescência em Matrizes de CV Colonizadas Após 21 Dias de Operação (Arranjos Semelhantes a Methanosarcina sp., Bacilos Com Extremidades Arredondadas, Bacilos com Extremidades Afiladas, Células Ovóides.
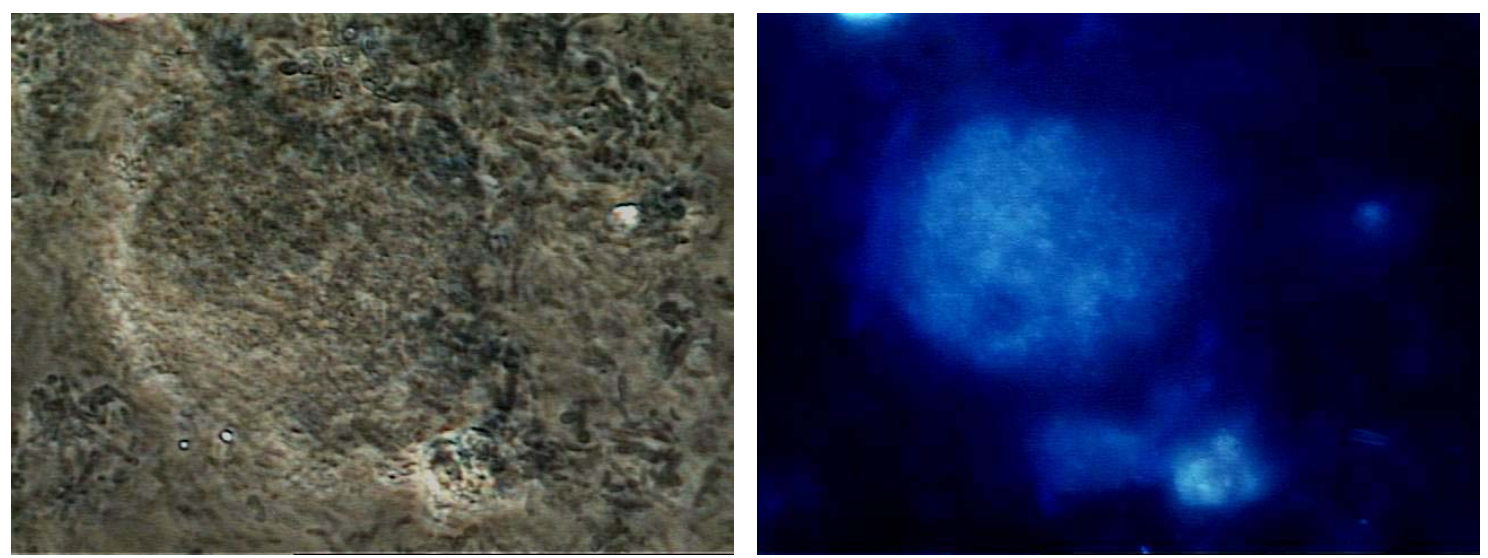

Figura 5.14. Morfologias Observadas por Meio de Microscopia Ótica, Utilizando

Luz Comum e Fluorescência, em Matrizes de CV Após 28 Dias de Operação do Reator. Arranjos Semelhantes a Methanosarcina sp., Bacilos com Extremidades Arredondadas, Bacilos com Extremidades Afiladas, Células Ovóides, Filamentos Semelhantes a Methanosaeta sp. e Bacilos Fluorescentes. 


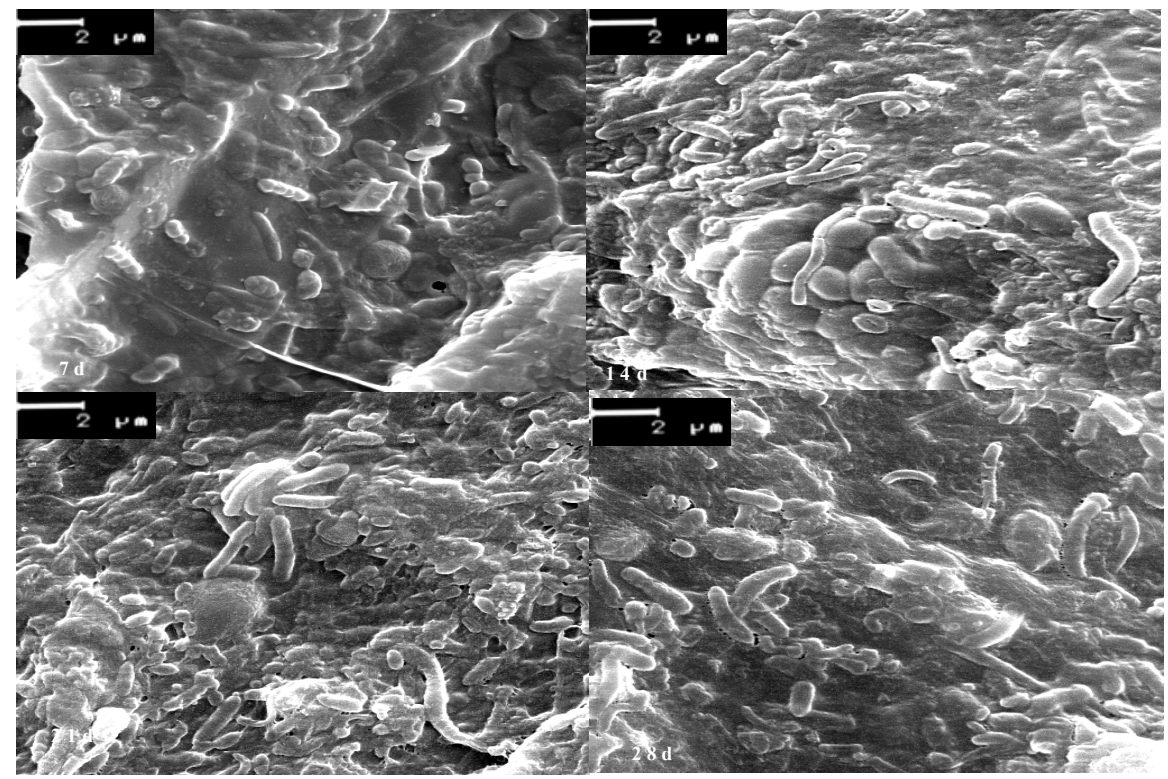

Figura 5.15. Morfologias Observadas por Microscopia Eletrônica de Varredura em Amostras de CV Após 7, 14, 21 e 28 Dias de Operação dos Reatores. Predomínio de Bacilos com Extremidades Arredondadas e Células Ovóides e, Presença de Cocos Formando Cadeias e Víbrios.

A predominância de células ovóides, semelhantes a Desulfobulbus propionicus sp., indica que esses microrganismos têm alta afinidade em aderir na superfície de $\mathrm{CV}$, pois, as condições de inoculação e alimentação foram idênticas para todos os suportes.

\subsubsection{Polietileno de Baixa Densidade Reciclado (PE)}

A Tabela 5.6 apresenta as morfologias e suas respectivas freqüências, observadas por microscopia ótica na biomassa aderida em PE. Após 28 dias observou-se a presença de morfologias semelhantes a Methanosarcina sp. (Figuras 5.16 a 5.19). Entretanto, morfologias semelhantes a BRS foram pouco freqüentes. A Figura 5.20 apresenta as morfologias aderidas em PE, observadas por MEV. 
Tabela 5.6. Caracterização Morfológica dos Microrganismos Aderidos em Polietileno de Baixa Densidade (Reciclado)

\begin{tabular}{|c|c|c|c|c|}
\hline \multirow[t]{2}{*}{ MORFOLOGIAS } & \multicolumn{4}{|c|}{ FREQÜÊNCIA OBSERVADA } \\
\hline & $7 \mathrm{~d}$ & $14 \mathrm{~d}$ & $21 \mathrm{~d}$ & $28 \mathrm{~d}$ \\
\hline \multicolumn{5}{|l|}{ Arqueas Metanogênicas } \\
\hline - Methanosarcinasp. & ++ & +++ & +++ & ++ \\
\hline - Methanosaeta sp. & + & + & ++ & ++ \\
\hline - Bacilos Fluorescentes & ++ & ++ & + & + \\
\hline \multicolumn{5}{|l|}{ Bactérias } \\
\hline - Bacilos com extremidades arredondadas & +++ & +++ & +++ & +++ \\
\hline - Bacilos curvos (víbrios) & ++ & + & ++ & ++ \\
\hline - Bacilos delgados & ++++ & ++++ & ++++ & +++ \\
\hline - Bacilos ovalados & +++ & ++ & ++ & ++ \\
\hline - Bacilos com grânulos & + & + & + & + \\
\hline - Cocos isolados & ++ & ++ & + & + \\
\hline - Cocos em cadeia & + & - & - & - \\
\hline - Filamentos & - & + & + & + \\
\hline
\end{tabular}
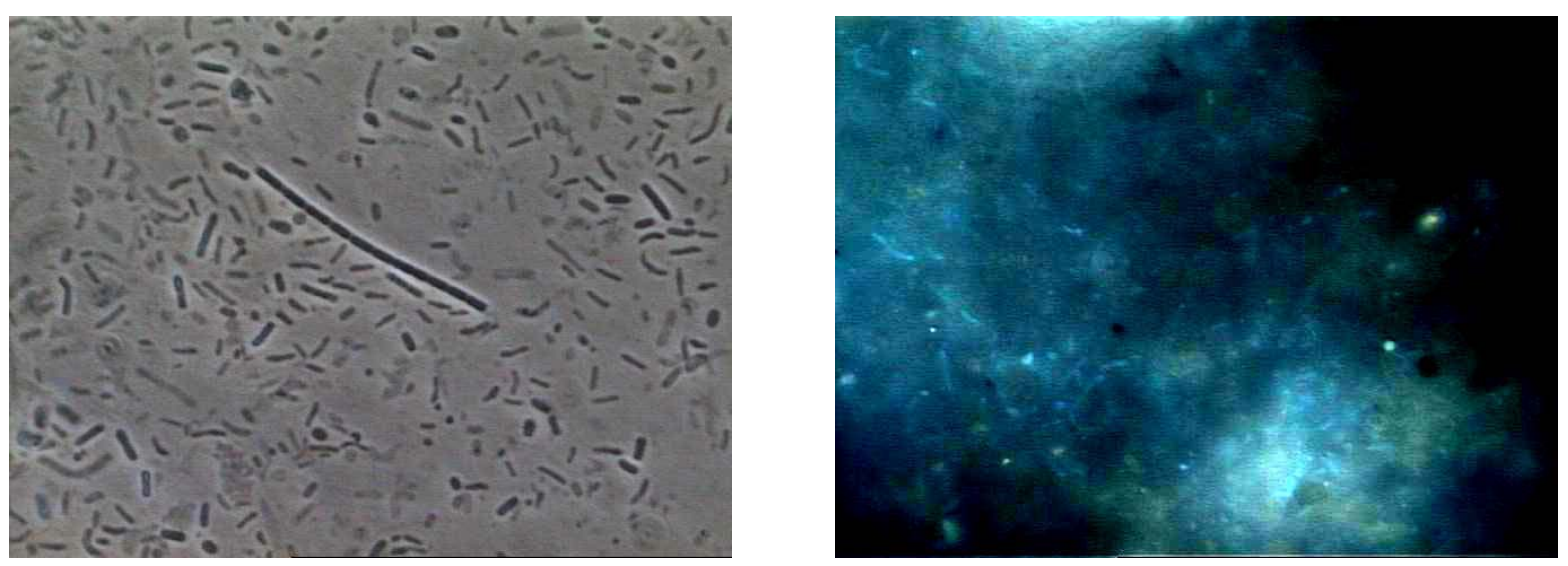

Figura 5.16. Morfologias Observadas por Meio de Microscopia Ótica Utilizando Luz Comum e Fluorescência, em Matrizes de PE, Após 7 Dias de Operação do Reator. Filamentos Semelhantes a Methanosaeta sp., Bacilos Fluorescentes, Víbrios, Bacilos Curtos com Extremidades Arredondadas e Células Ovóides. 

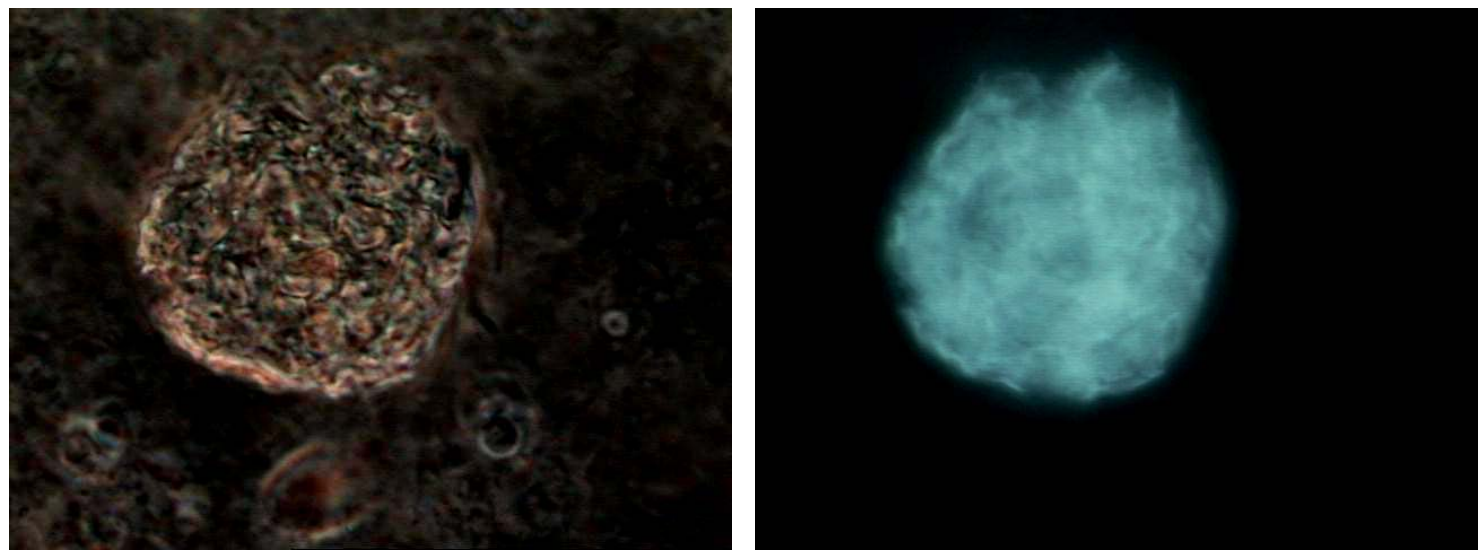

Figura 5.17. Morfologias Observadas por Meio de Microscopia Ótica, Utilizando Luz Comum e Fluorescência, em Matrizes de PE Após 14 Dias de Operação do Reator. Arranjos Semelhantes a Methanosarcina sp..
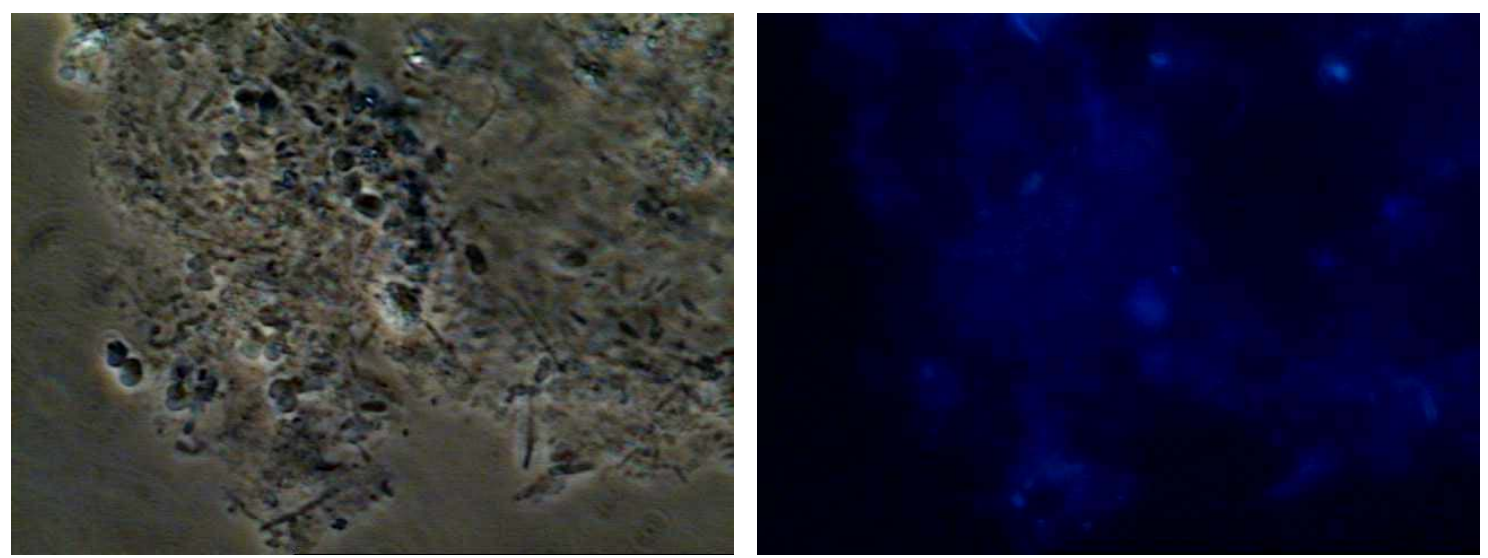

Figura 5.18. Morfologias Observadas por Meio de Microscopia Ótica, Utilizando Luz Comum e Fluorescência, em Matrizes de PE Após 21 Dias de Operação do Reator. Arranjos Semelhantes a Methanosarcina sp., Filamentos Semelhantes a Methanosaeta sp., Bacilos com Extremidades Arredondadas e Diplococos. 

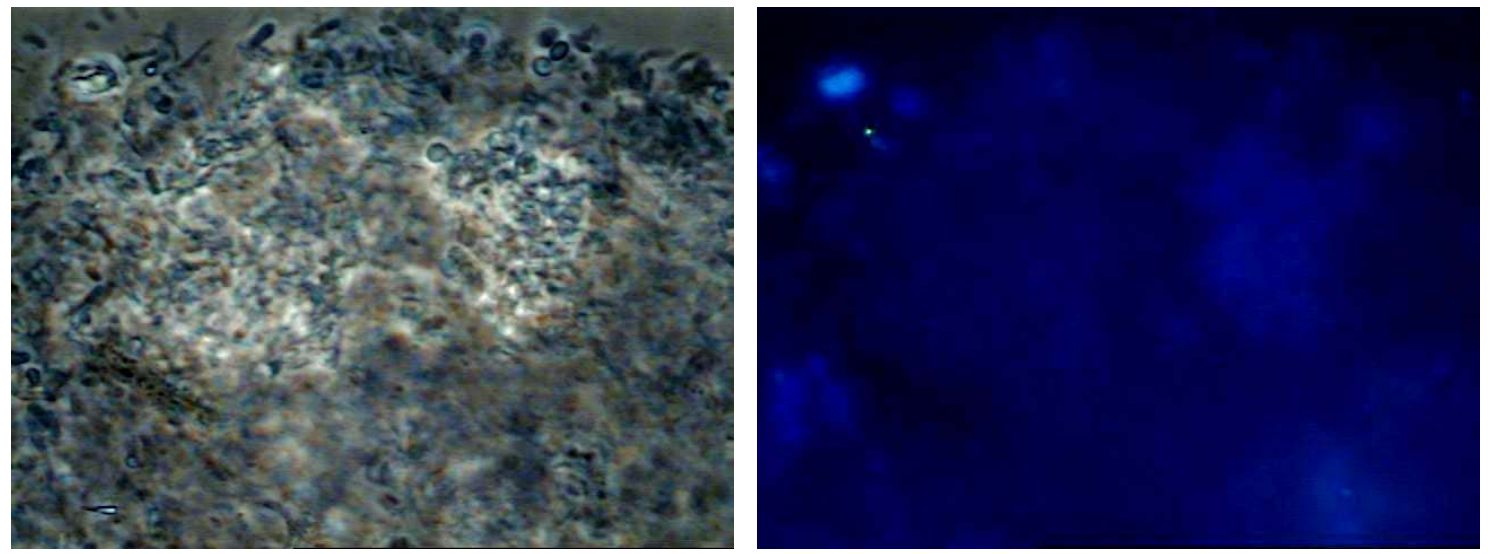

Figura 5.19. Morfologias Observadas por Meio de Microscopia Ótica, Utilizando Luz Comum e Fluorescência, em Matrizes de PE Após 28 Dias de Operação do Reator. Arranjos Semelhantes a Methanosarcina sp., Filamentos Semelhantes a Methanosaeta sp., Bacilos com Extremidades Arredondadas, Víbrios, e Células Ovóides.

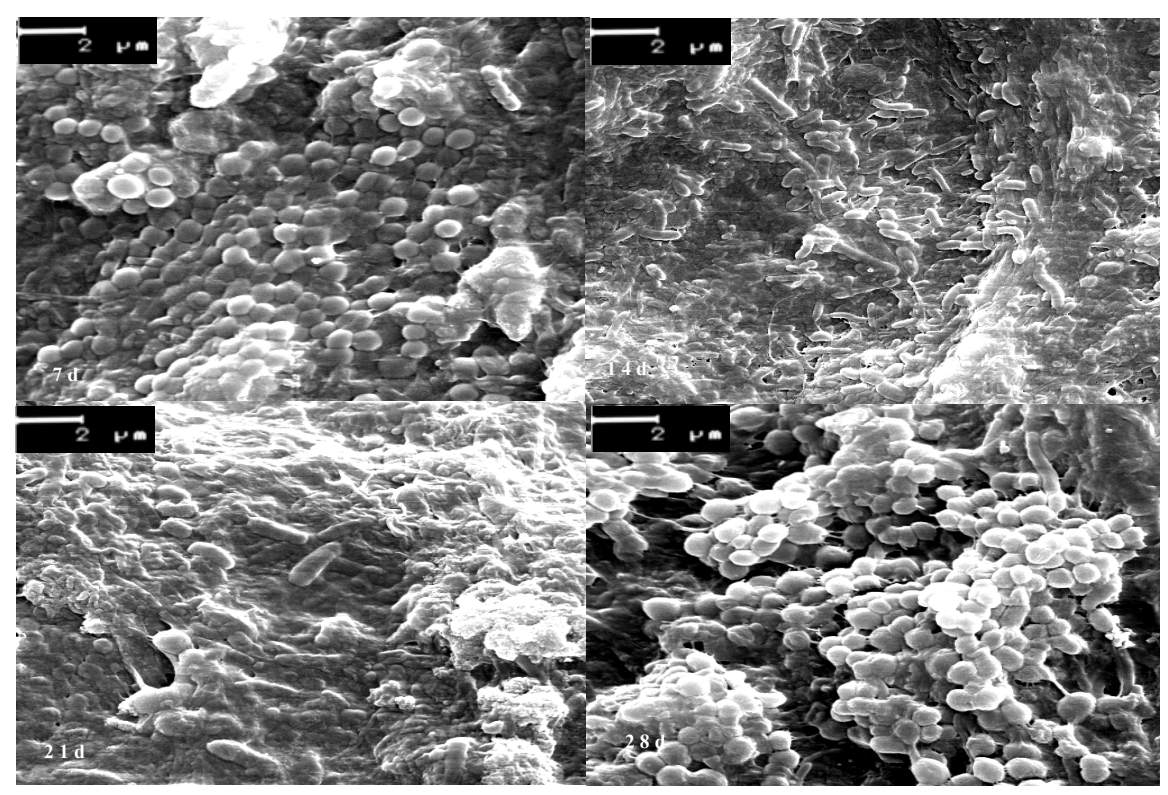

Figura 5.20. Morfologias Observadas em Matrizes de Polietileno de Baixa Densidade Após 7, 14, 21 e 28 Dias de Operação do Reator. Predomínio de Morfologias Semelhantes a Metanosarcina sp. e Presença de Bacilos com Extremidades Arredondadas, e Células Ovóides.

\subsubsection{Cerâmica (CE)}

A Tabela 5.7 apresenta as morfologias e suas respectivas freqüências observadas por microscopia ótica na biomassa aderida em CE (Figuras 5.21 a 5.24). 
A Figura 5.25 apresenta as morfologias aderidas em CE observadas por MEV. Foram observadas morfologias semelhantes a BRS, como, por exemplo, bacilos semelhantes a Desulfobacter sp., que oxidam completamente acetato a $\mathrm{CO}_{2}$ (MADIGAN et al., 1997), víbrios, cocos em cadeia, e morfologias semelhantes a Methanosaeta sp.. Entretanto, a quantidade de microrganismos aderidos em CE foi menor que em PU e CV.

Tabela 5.7. Caracterização Morfológica dos Microrganismos Aderidos em Cerâmica Porosa Confeccionada com Alumina

\begin{tabular}{|c|c|c|c|c|}
\hline \multirow[t]{2}{*}{ MORFOLOGIAS } & \multicolumn{4}{|c|}{ FREQÜÊNCIA OBSERVADA } \\
\hline & $7 \mathrm{~d}$ & $14 \mathrm{~d}$ & $21 \mathrm{~d}$ & $28 \mathrm{~d}$ \\
\hline \multicolumn{5}{|l|}{ Arqueas Metanogênicas } \\
\hline - Methanosarcina sp. & + & + & + & ++ \\
\hline - Methanosaeta sp. & + & + & + & ++ \\
\hline - Bacilos Fluorescentes & ++ & ++ & ++ & ++ \\
\hline \multicolumn{5}{|l|}{ Bactérias } \\
\hline - Bacilos com extremidades arredondadas & +++ & ++ & ++ & ++ \\
\hline - Bacilos curvos (víbrios) & ++ & ++ & ++ & ++ \\
\hline - Bacilos delgados & ++ & +++ & +++ & +++ \\
\hline - Bacilos ovalados & ++ & ++ & + & ++ \\
\hline - Bacilos com grânulos & ++ & +++ & ++ & ++ \\
\hline - Cocos isolados & + & ++ & + & + \\
\hline - Cocos em cadeia & - & + & + & - \\
\hline - Espiroqueta & + & - & - & - \\
\hline - Filamentos & + & + & + & + \\
\hline
\end{tabular}



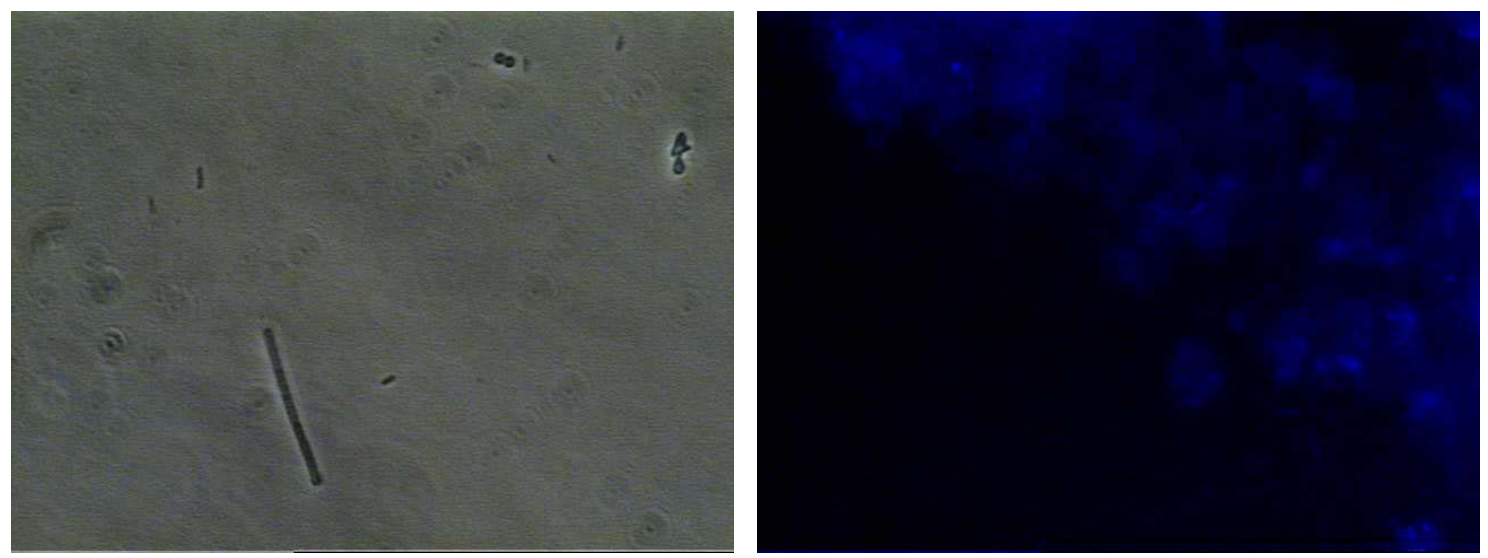

Figura 5.21. Morfologias Observadas por Microscopia Ótica, Utilizando Luz Comum e Fluorescência, em Matrizes de CE Após 7 Dias de Operação. Arranjos Semelhantes a Methanosarcina sp., Filamentos Semelhantes a Methanosaeta sp.e Bacilos Fluorescentes.
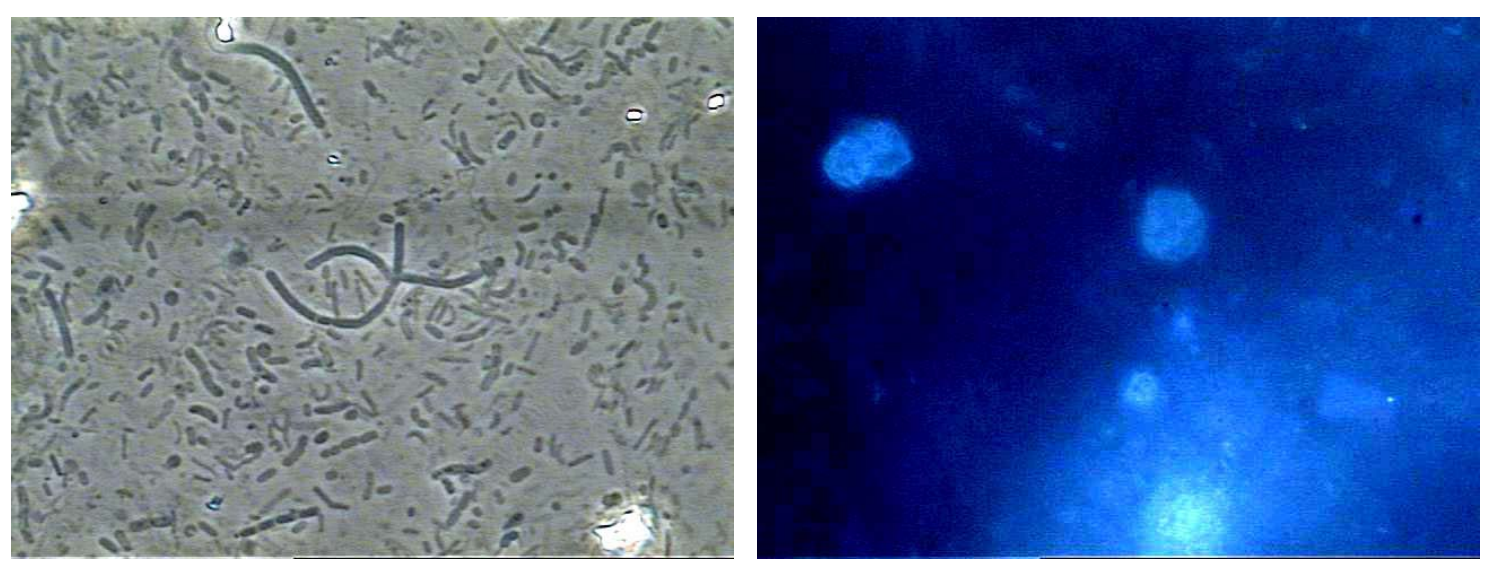

Figura 5.22. Morfologias Observadas por Microscopia Ótica, Contraste de Fase e Fluorescência, em Matrizes de CE Após 14 Dias de Operação. Arranjos Semelhantes a Methanosarcina sp., Filamentos Semelhantes a Methanosaeta sp., Bacilos Fluorescentes, Víbrios, Bacilos Curtos com Extremidades Arredondadas, Células Ovóides e Bacilos em Cadeia. 

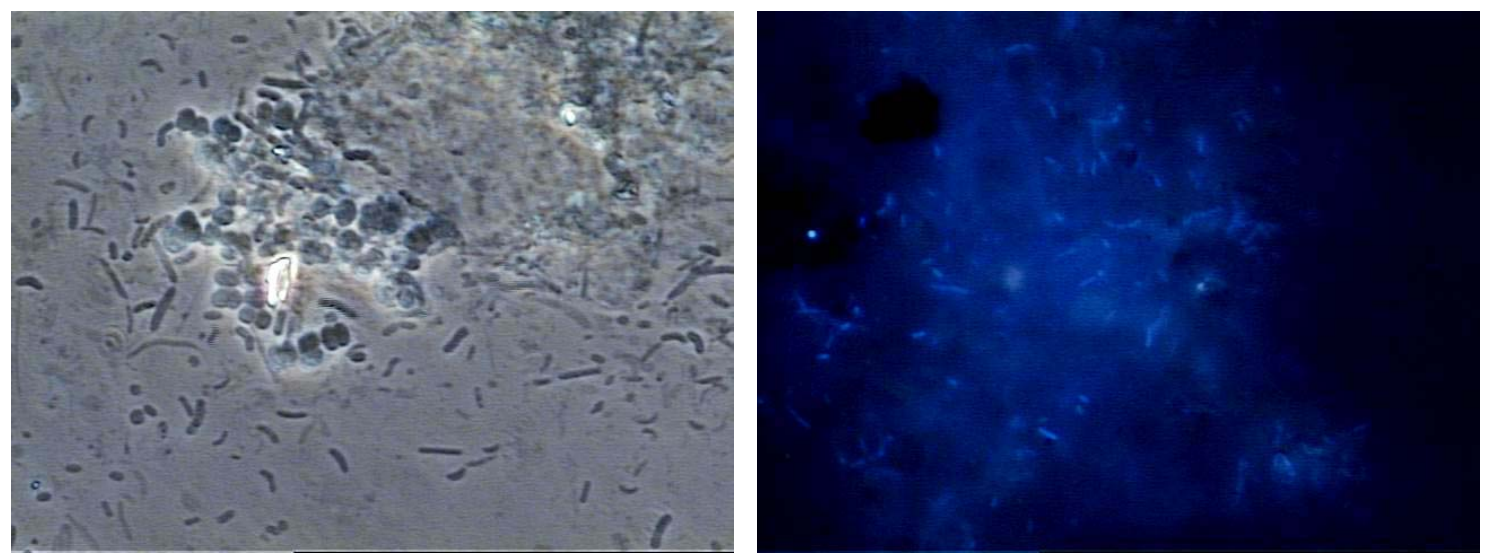

Figura 5.23. Morfologias Observadas por Microscopia Ótica, Utilizando Luz Comum e Fluorescência, em Matrizes de CE Após 21 Dias de Operação do Reator. Arranjos Semelhantes a Methanosarcina sp., Bacilos Fluorescentes, Víbrios, Bacilos Curtos com Extremidades Arredondadas e Células Ovóides.
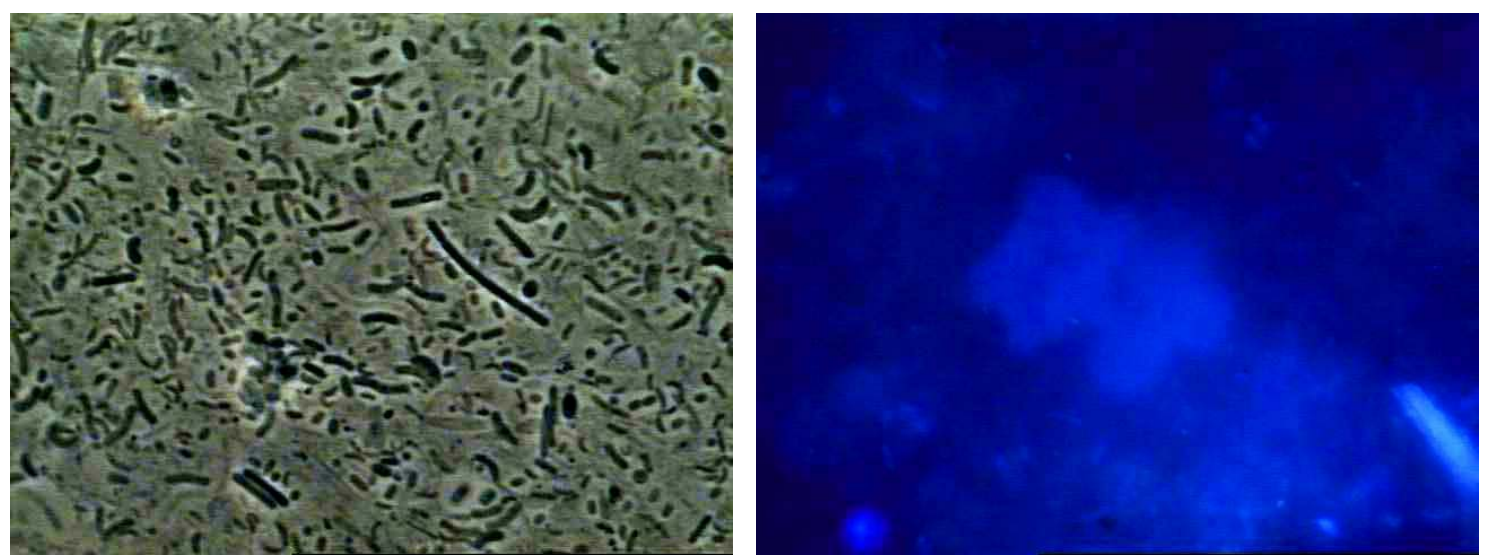

Figura 5.24. Morfologias Observadas por Microscopia Ótica, Utilizando Luz Comum e Fluorescência, em Matrizes de CE Após 28 Dias de Operação do Reator. Arranjos Semelhantes a Methanosarcina sp., Filamentos Semelhantes a Methanosaeta sp., Bacilos Fluorescentes, Víbrios, Bacilos Curtos com Extremidades Arredondadas e Células Ovóides. 


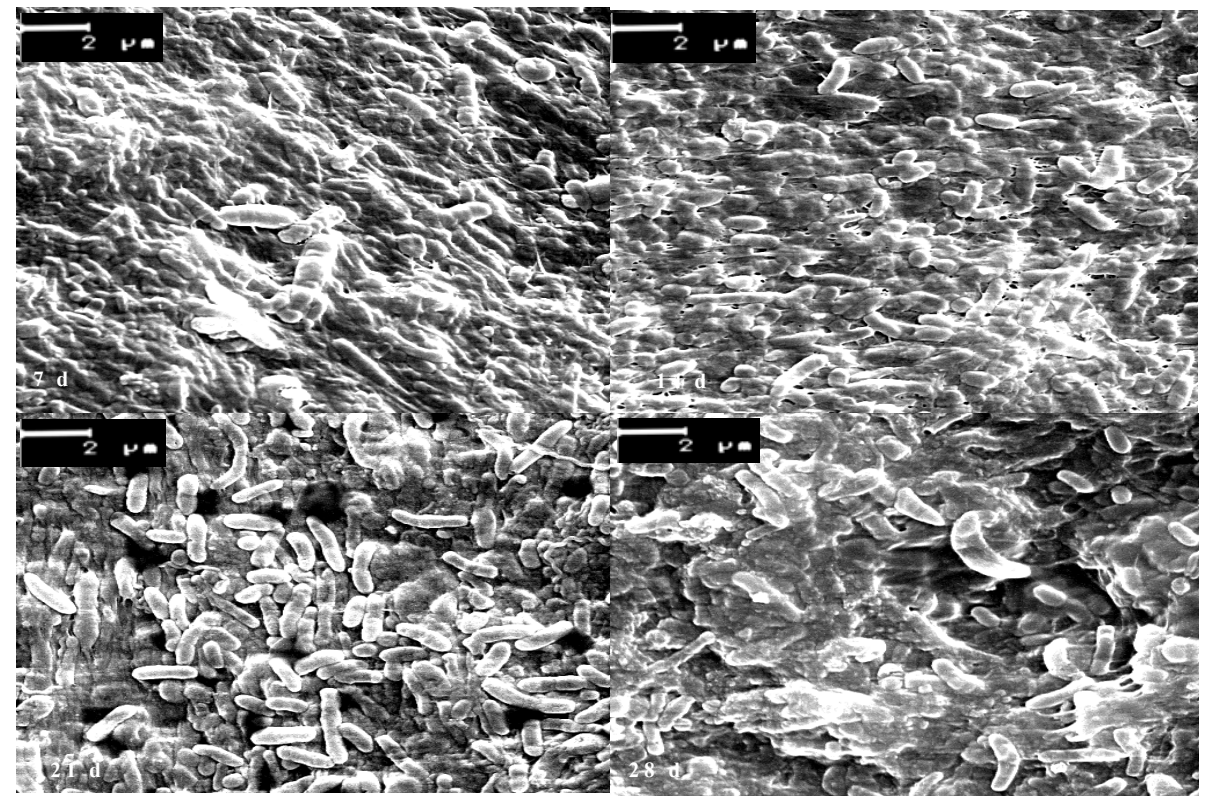

Figura 5.25. Morfologias Observadas em CE, Após 7, 14, 21 e 28 Dias de Operação do Reator: Predomínio de Bacilos com Extremidades Arredondadas, Presença de Víbrios, Células Ovóides e Methanosaeta Sp..

\subsubsection{Resultados Obtidos por FISH (Quantificação de Grupos Microbianos)}

A análise por FISH revelou que houve predomínio do Domínio Bacteria nos quatro `MS estudados (Figura 5.26). O total de células bacterianas detectadas com a sonda EUB338 foram quantificadas em 76,2\% ( $\pm 1,6 \%), 79,7 \%( \pm 1,3 \%), 84,4 \%$ $( \pm 1,4 \%)$ e $60,2 \%( \pm 1,0 \%)$, em PU, CV, PE e CE, respectivamente, do total de células coradas com DAPI. A concentração média de células detectadas com a sonda ARC915 foi igual a $33,1 \%( \pm 1,6 \%), 25,4 \%( \pm 1,3 \%), 22,6 \%( \pm 1,1 \%)$ e $41,9 \%$ $( \pm 1,0 \%)$, em PU, CV, PE e CE, respectivamente, do total de células coradas com DAPI.

A concentração média de células detectadas com a sonda SRB385 foi $44,8 \%$ $( \pm 2,1 \%), 55,4 \%( \pm 1,2 \%), 32,7 \%( \pm 1,4 \%)$ e $18,1 \%( \pm 1,1 \%)$, em PU, CV, PE e CE, respectivamente, do total de células coradas com DAPI. 

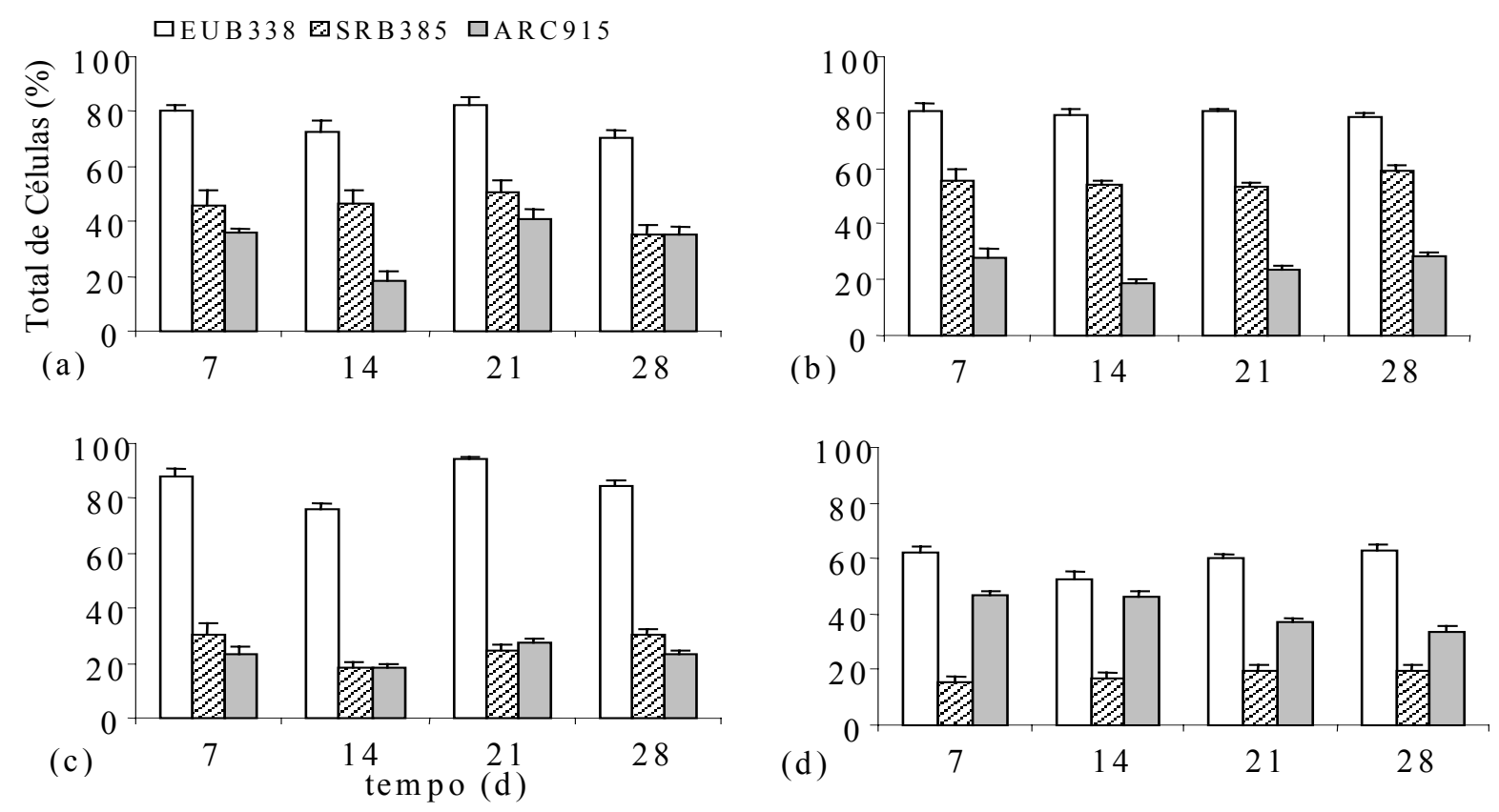

Figura 5.26. Composição da Comunidade Microbiana, Determinada por Meio de FISH em Amostras de Matrizes Colonizadas nos Reatores Após: 7, 14, 21 E 28 Dias de Operação com (A) PU, (B) CV, (C) PE e (D) CE. Porcentagens Relativas de Células Pertencentes aos Domínios: Bacteria (EUB338), BRS (SRB385) e Arqueas (ARC915). As Barras de Erros Indicam os Erros-Padrão (HIRASAWA, 2003).

\subsubsection{Resultados da Análise das Superfícies dos Materiais suporte e Biomassa - Medição do Ângulo de Contato com Água}

A análise do grau de hidrofobicidade da superfície da biomassa retida em membrana de $1,2 \mu \mathrm{m}$ e dos MS estudados foi baseada na consideração prática de que valores de ângulo de contato $(\theta)$ inferiores a $90^{\circ}$ caracterizam superfícies hidrofílicas e, valores superiores, superfícies hidrofóbicas (ADAMSON, 1990).

Os valores médios de $\theta$ para as superfícies da biomassa, CV, PU e PE foram $19 \pm 3^{\circ}, 101 \pm 9^{\circ}, 89 \pm 10^{\circ}$ e $86 \pm 7^{\circ}$, respectivamente. Não foi possível seguir esse procedimento para avaliar a superfície de CE, porque a alta porosidade desse material impossibilitou a fixação da bolha de água. A partir deste conceito, a superfície da biomassa retida em membrana de 1,2 $\mu \mathrm{m}$ foi hidrofílica enquanto que as superfícies dos materiais suporte avaliados foram hidrofóbicas. $\mathrm{O}$ valor de ângulo 
de contato médio, medido sobre a superfície de PE, foi igual ao valor relatado por ADAMSON (1990).

VERRIER et al. (1987) utilizaram essa técnica para caracterizar as superfícies de materiais poliméricos, inclusive polietileno, sobre o qual os autores observaram ângulo de contato similar ao observado neste trabalho $\left(90^{\circ}\right)$ e concluíram que a adesão de AM em suportes inertes é influenciada pela superfície das células e pelas características do material suporte.

Nesse trabalho, as matrizes de CV apresentaram maior grau de hidrofobicidade, seguidas pelas matrizes de PU e de PE. Essa característica pode ser somente correlacionada com as BRS aderidas em cada tipo de material suporte, pois foi verificado que as BRS aderiram principalmente em CV (55\%), seguida por PU (45\%) e PE (33\%). Contudo, não se pode concluir que o grau de hidrofobicidade foi o único fator que afetou a adesão de BRS, uma vez que os materiais foram de diferentes características como porosidade e tamanho de poros.

\subsubsection{Considerações gerais}

Essa etapa do trabalho, demonstrou: (i) a importância da escolha de materiais suporte para serem utilizados em reatores anaeróbios contendo biomassa imobilizada; (ii) as diferenças entre os MS conduzem a diferentes equilíbrios microbianos, o que afeta diretamente o desempenho e a estabilidade do reator; (iii) a seleção de biomassa é, provavelmente, relacionada a características intrínsecas dos materiais, como, por exemplo, carga líquida, grau de hidrofobicidade, porosidade e rugosidade; (iv) os resultados obtidos por FISH revelaram que PU e CV apresentaram melhor aderência de BRS, enquanto PE foi colonizado, principalmente, por microrganismos pertencentes ao grupo de bactérias não redutoras de sulfato e $\mathrm{CE}$ apresentou um microambiente rico em microrganismos metanogênicos.

Os resultados obtidos por FISH indicaram que cada material pode ser selecionado dependendo da aplicação e das características da água residurária a ser tratada. Por exemplo, aqui foi demonstrado que CV e PU devem ser utilizados em sistemas que visam o processo de redução de sulfato, enquanto que CE pode ser usado para aumentar a produção de metano ou prevenir a geração de $\mathrm{H}_{2} \mathrm{~S}$ em sistemas de tratamento anaeróbio de águas residuárias. PE pode ser utilizado, principalmente, em reatores acidogênicos em sistemas de duas fases. 
Portanto, é conveniente, antes de se projetar reatores contendo células imobilizadas, que vários MS disponíveis, sejam testados utilizando-se de uma metodologia simples, como aqui apresentado, para evitar a construção de sistemas instáveis. Foi claramente demonstrado que, o sucesso ou falha de um reator anaeróbio, para uma aplicação específica, podem ser diretamente relacionados com o MS utilizado para a formação do biofilme.

Com base nesses ensaios de adesão, CV e PU foram escolhidos como suporte de imobilização nos reatores operados em bateladas seqüenciais.

\subsection{Ensaios Hidrodinâmicos nos Reatores Operados em Bateladas Seqüenciais}

O estudo hidrodinâmico dos ASBBR's utilizados foi realizado com a finalidade de se determinar o tempo de mistura nesses reatores. O conhecimento do tempo de mistura foi importante para verificar se os reatores operaram em regime de mistura completa. Essa comprovação foi considerada essencial neste trabalho, porque, as amostragens para determinação das principais variáveis, para avaliação temporal do processo de biodessulfatação foram pontuais e, dessa forma, os resultados são representativos somente para regime de mistura completa.

Os valores de $\mathrm{pH}$ obtidos antes e após o pulso do traçador foram plotados em função do tempo. A análise do gráfico revelou um comportamento sigmoidal, para o decaimento do $\mathrm{pH}$ nos reatores agitados mecanicamente, e em diferentes velocidades: 90, 180, 300, 500 e $800 \mathrm{rpm}$.

Desse modo, o modelo sigmoidal, tipo Boltzman foi o que melhor se ajustou aos dados experimentais normalizados, conforme a Equação 5.1.

$\mathrm{y}=\frac{\mathrm{pH}_{\mathrm{f}}-\mathrm{pH}}{\mathrm{pH}_{\mathrm{f}}-\mathrm{pH}_{\mathrm{o}}}=\frac{\mathrm{y}_{\mathrm{i}}-\mathrm{y}_{\mathrm{f}}}{1+\mathrm{e}^{\left(\mathrm{t}-\mathrm{t}_{\mathrm{o}}\right) / \tau}}+\mathrm{y}_{\mathrm{f}}$

$\mathrm{Na}$ expressão (5.1), y é o valor normalizado do $\mathrm{pH}, \mathrm{pH}_{\mathrm{f}}$ é o $\mathrm{pH}$ final, atingido após a estabilização da resposta ao pulso, $\mathrm{pH}_{\mathrm{o}}$ é o $\mathrm{pH}$ inicial da água no reator, antes do pulso, $\mathrm{y}_{\mathrm{i}}$ é o valor de y quando $\mathrm{pH}$ igual a $\mathrm{pH}_{\mathrm{o}}$ (igual a 1 ), $\mathrm{y}_{\mathrm{f}}$ é o valor de y quando $\mathrm{pH}$ igual a $\mathrm{pH}_{\mathrm{f}}$ (igual a 0 ), $\mathrm{t}_{\mathrm{o}}$ é tempo correspondente ao centro da sigmóide e $\tau$ é a constante de tempo. 
Nas Figuras 5.27 a 5.36 são apresentadas as curvas, já normalizadas, obtidas após estímulo com solução de ácido sulfúrico $\sim 1 \mathrm{M}$. Admitindo-se que, o tempo de mistura $\left(\mathrm{t}_{\mathrm{M}}\right)$ significa o tempo para se atingir $99,9 \%$ da resposta final, ou seja, quando $\left(\mathrm{pH}_{\mathrm{f}}-\mathrm{pH}\right)$ for igual a $\left[0,001\left(\mathrm{pH}_{\mathrm{f}}-\mathrm{pH}_{\mathrm{o}}\right)\right], \mathrm{t}_{\mathrm{M}}$, pode ser calculado pela resolução das equações 5.2 a 5.6 .

$y=\frac{1-0}{1+e^{\left(t-t_{0}\right) / \tau}}+0$

$0,001=\frac{1}{1+e^{\left(t_{M}-t_{0}\right) / \tau}}$

$\ln 0,001=\ln \frac{1}{1+e^{\left(t_{M}-t_{0}\right) / \tau}}=\ln 1-\ln 1-\ln e^{\left(t_{M}-t_{0}\right) / \tau}$

$-6,91=\frac{-t_{M}+t_{0}}{\tau}$

$\mathrm{t}_{\mathrm{M}}=6,91 \cdot \tau+\mathrm{t}_{\mathrm{o}}$

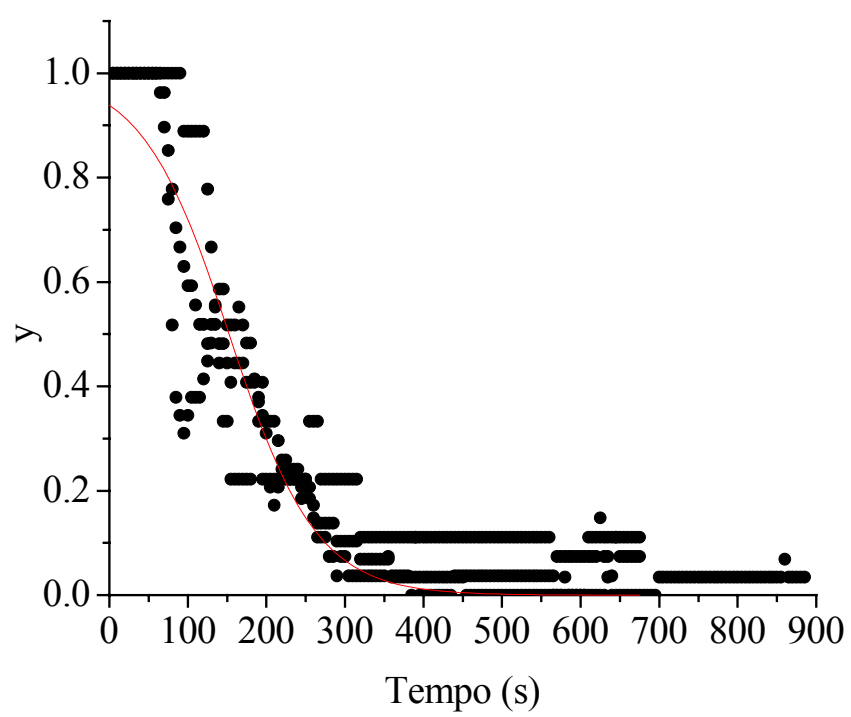

Figura 5.27. Ajuste Médio do Modelo de Boltzmann aos Valores Normalizados dos Dados Experimentais, Obtidos no Perfil Hidrodinâmico do Reator Preenchido com CV Sob Freqüência de Agitação de 90 rpm. 


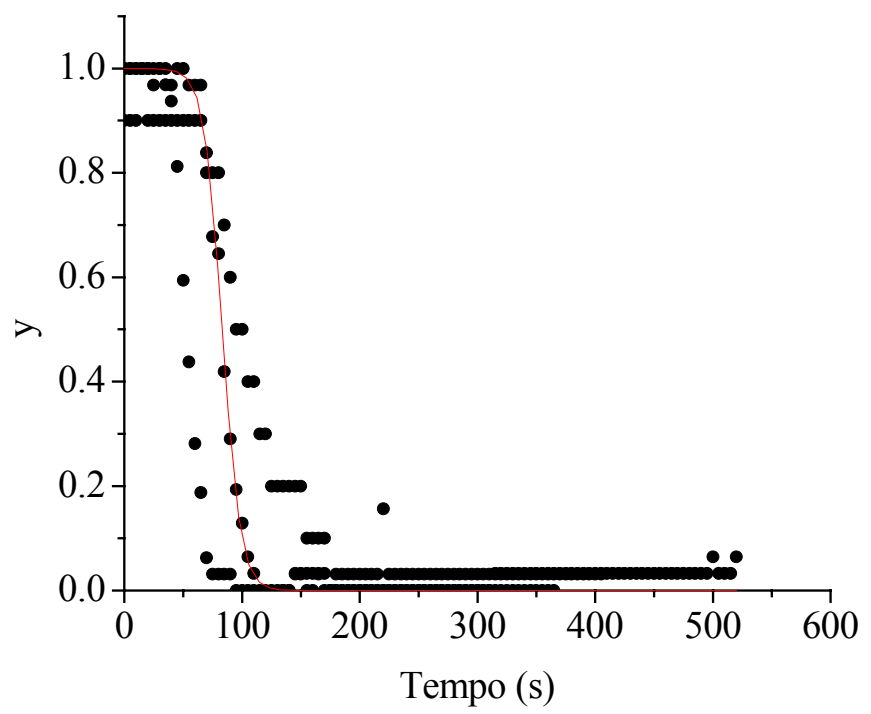

Figura 5.28. Ajuste Médio d Modelo de Boltzmann aos Valores Normalizados dos Dados Experimentais, Obtidos no Perfil Hidrodinâmico do Reator Preenchido com CV Sob Freqüência de Agitação de 180 rpm.

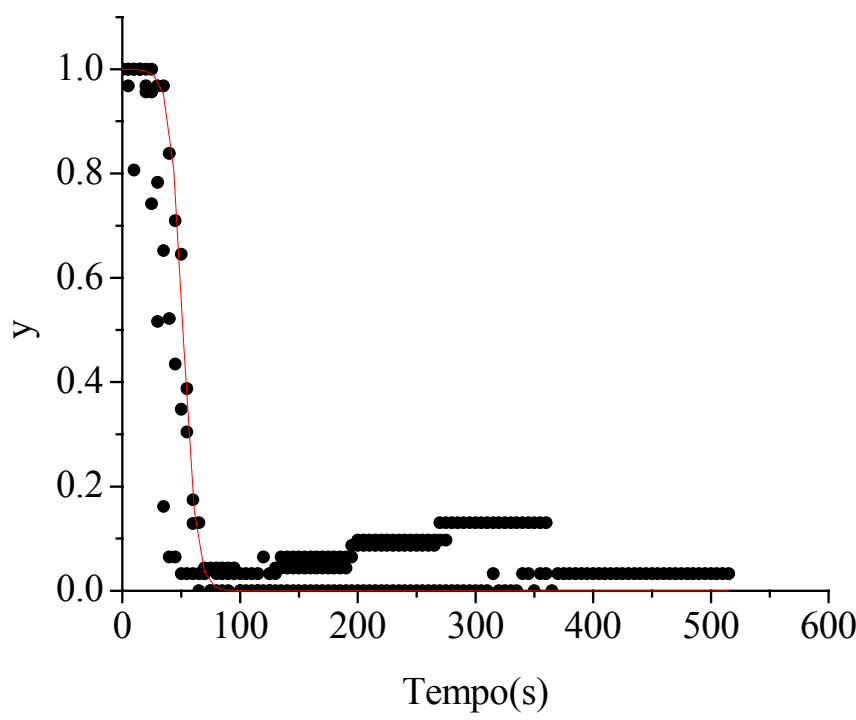

Figura 5.29. Ajuste Médio do Modelo de Boltzmann aos Valores Normalizados dos Dados Experimentais Obtidos no Perfil Hidrodinâmico do Reator Preenchido com CV Sob Freqüência de Agitação de 300 rpm. 


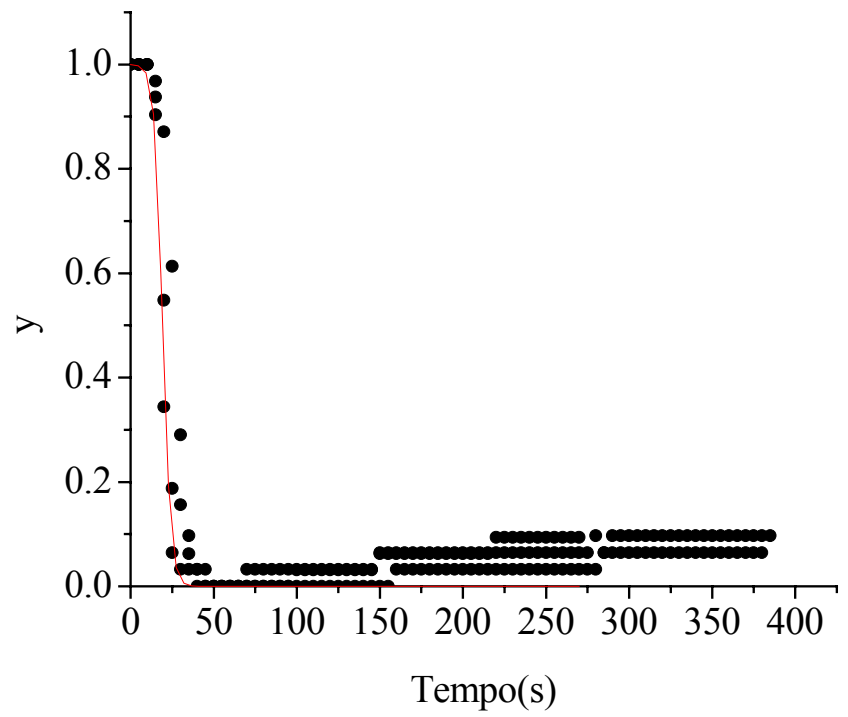

Figura 5.30. Ajuste Médio do Modelo de Boltzmann aos Valores Normalizados dos Dados Experimentais, Obtidos no Perfil Hidrodinâmico do Reator Preenchido com CV Sob Freqüência de Agitação de 500 Rpm.

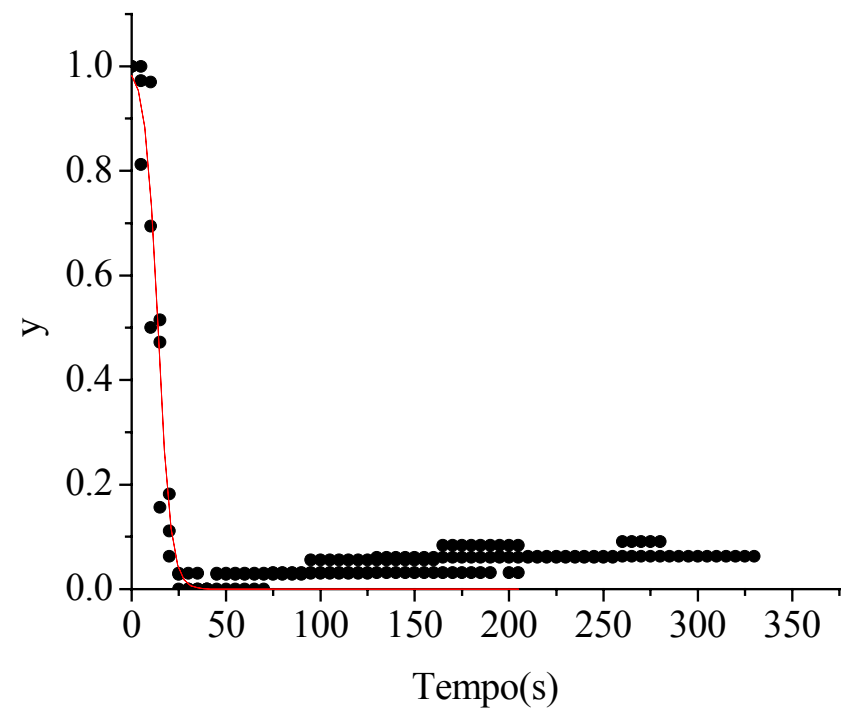

Figura 5.31. Ajuste Médio do Modelo de Boltzmann aos Valores Normalizados dos Dados Experimentais, Obtidos no Perfil Hidrodinâmico do Reator Preenchido com CV Sob Freqüência de Agitação de 800 rpm. 


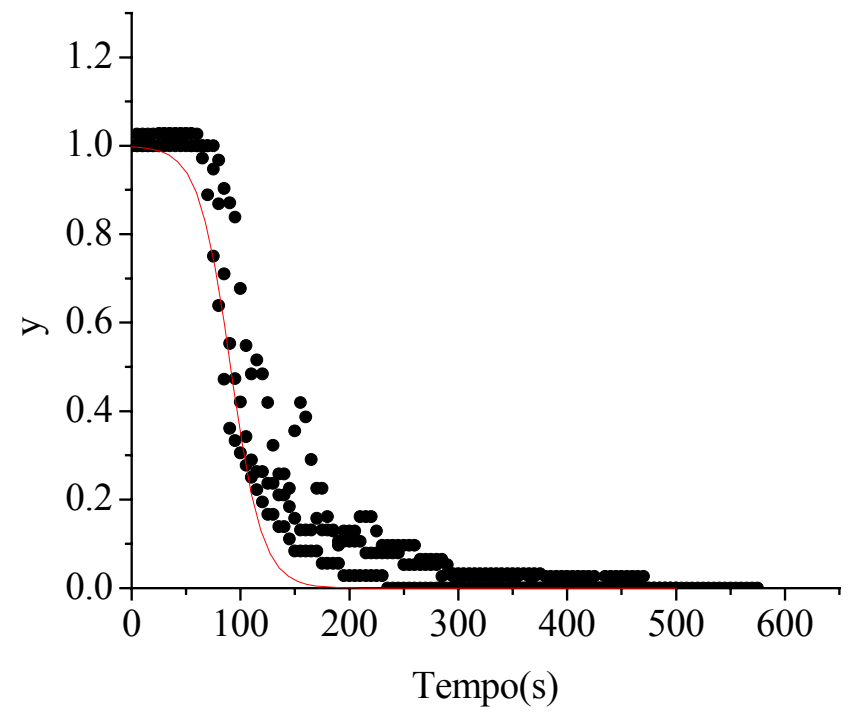

Figura 5.32. Ajuste Médio Do Modelo de Boltzmann aos Valores Normalizados dos Dados Experimentais, Obtidos no Perfil Hidrodinâmico do Reator Preenchido com PU Sob Freqüência de Agitação de 90 rpm.

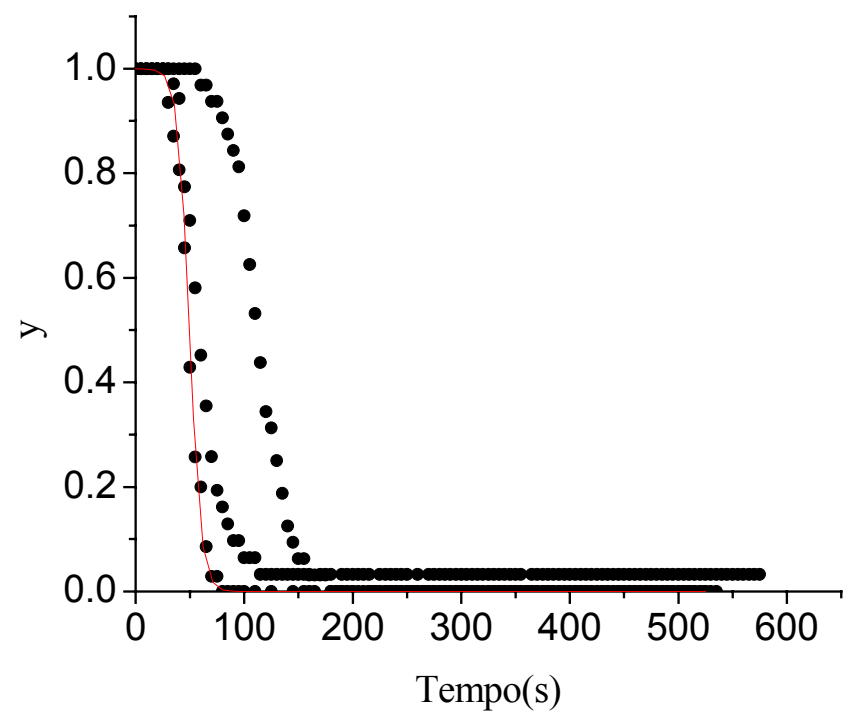

Figura 5.33. Ajuste Médio do Modelo de Boltzmann aos Valores Normalizados dos Dados Experimentais, Obtidos no Perfil Hidrodinâmico do Reator Preenchido com PU Sob Freqüência de Agitação de 180 rpm. 


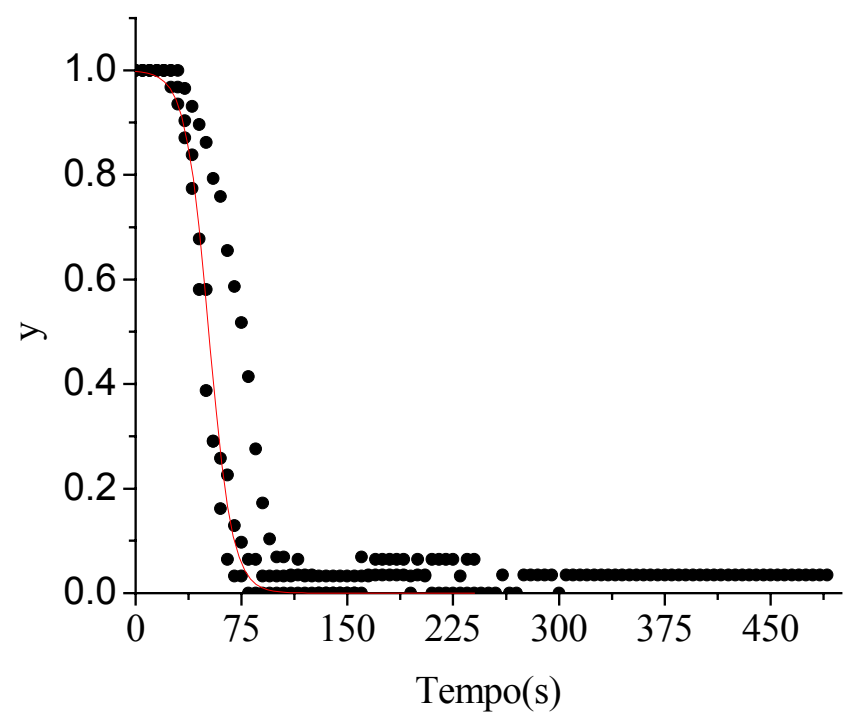

Figura 5.34. Ajuste Médio do Modelo de Boltzmann aos Valores Normalizados dos Dados Experimentais, Obtidos no Perfil Hidrodinâmico do Reator Preenchido com PU Sob Freqüência de Agitação de 300 rpm.

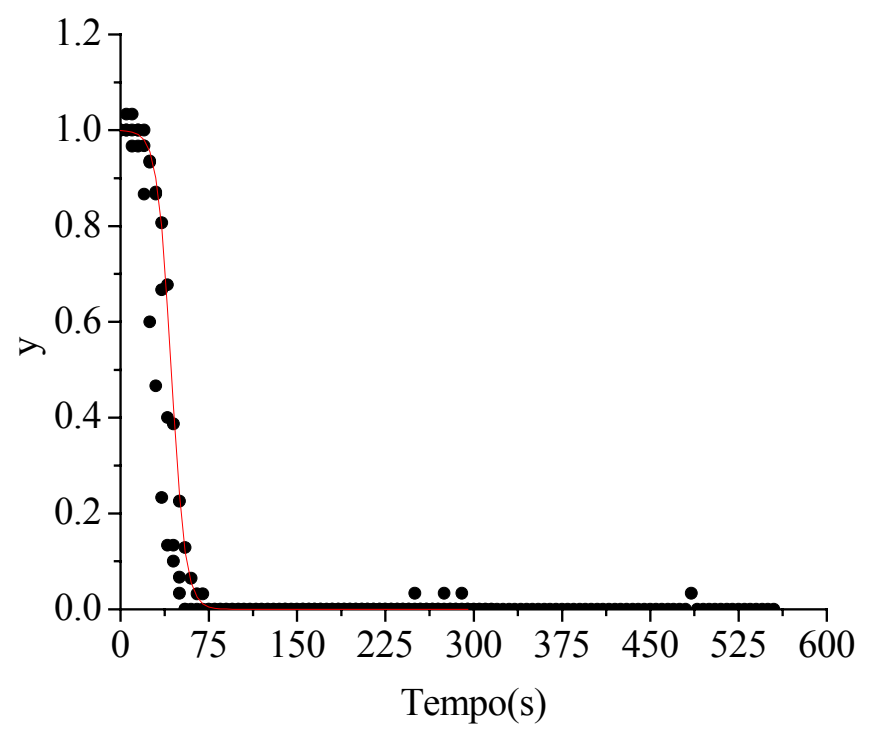

Figura 5. 35. Ajuste Médio do Modelo de Boltzmann aos Valores Normalizados dos Dados Experimentais, Obtidos no Perfil Hidrodinâmico do Reator Preenchido com PU Sob Freqüência de Agitação de 500 rpm. 


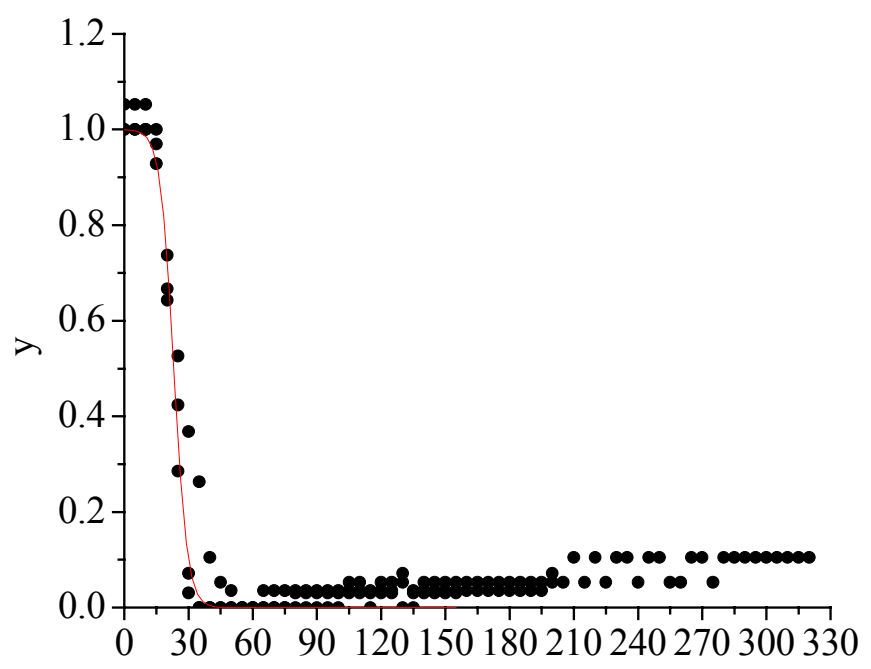

Tempo(s)

Figura 5.36. Ajuste Médio do Modelo de Boltzmann aos Valores Normalizados dos Dados Experimentais, Obtidos no Perfil Hidrodinâmico do Reator Preenchido com PU Sob Freqüência de Agitação de 800 rpm.

As Tabelas 5.8 e 5.9 apresentam os valores de tempo de mistura $\left(\mathrm{t}_{\mathrm{M}}\right)$, calculados para cada freqüência de agitação aplicada, nos reatores com CV e PU, respectivamente, e a Figura 5.37 apresenta o perfil dos $t_{M}$ com a variação na freqüência de agitação.

Tabela 5.8. Valores da Constante de Tempo $(\tau)$, do Centro da Sigmóide $\left(\mathrm{t}_{0}\right)$ e do Tempo de Mistura ( $\left.t_{\mathrm{m}}\right)$, Calculados pelo Modelo de Boltzmann, para as Velocidades de Agitação Aplicadas ao Reator Contendo CV.

\begin{tabular}{cccc}
\hline \multicolumn{4}{c}{ Tempo de mistura do reator com carvão } \\
\hline Agitação $(\mathrm{rpm})$ & $\tau(\mathrm{s})$ & $\mathrm{t}_{0}(\mathrm{~s})$ & $\mathrm{t}_{\mathrm{M}}(\mathrm{s})$ \\
\hline 90 & 56 & 152 & 539 \\
180 & 8 & 83 & 138 \\
300 & 5 & 52 & 87 \\
500 & 2 & 19 & 33 \\
800 & 3 & 14 & 35 \\
\hline
\end{tabular}


Tabela 5.9. Valores da Constante de Tempo $(\tau)$, do Centro da Sigmóide $\left(\mathrm{t}_{0}\right)$ e do Tempo de Mistura $\left(\mathrm{t}_{\mathrm{m}}\right)$, Calculados pelo Modelo de Boltzmann, para as Velocidades de Agitação Aplicadas ao Reator Contendo PU.

\begin{tabular}{cccc}
\hline \multicolumn{4}{c}{ Tempo de mistura do reator com espuma } \\
\hline Agitação $(\mathrm{rpm})$ & $\tau(\mathrm{s})$ & $\mathrm{t}_{0}(\mathrm{~s})$ & $\mathrm{t}_{\mathrm{M}}(\mathrm{s})$ \\
\hline 90 & 15 & 91 & 195 \\
180 & 5 & 49 & 84 \\
300 & 8 & 52 & 107 \\
500 & 6 & 43 & 84 \\
800 & 3 & 23 & 44 \\
\hline
\end{tabular}

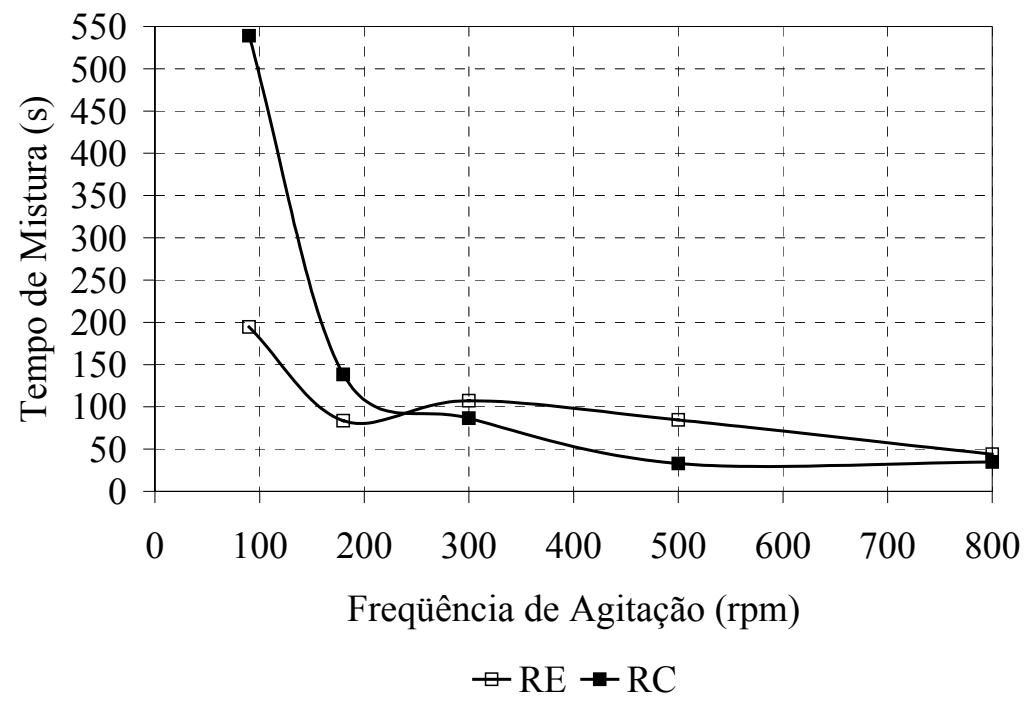

Figura 5.37. Tempo de Mistura em Função da Freqüência de Agitação.

Os resultados obtidos para o reator com carvão (RC) mostram que até 500 rpm o tempo de mistura diminuiu com o aumento da freqüência de agitação, mas, os valores obtidos: $36 \mathrm{~s}$ para $800 \mathrm{rpm}$ a $540 \mathrm{~s}(9 \mathrm{~min})$ para $90 \mathrm{rpm}$, foram insignificantes em relação ao tempo de ciclo de 24 horas. No reator com PU (RE) o tempo de mistura foi diminuindo com o aumento da freqüência de agitação até $800 \mathrm{rpm}$. Todavia, os valores de $\mathrm{t}_{\mathrm{M}}$, obtidos entre $36 \mathrm{~s}$ e $180 \mathrm{~s}$ também foram insignificantes em relação ao tempo de ciclo de 24 horas. Portanto, os dois reatores apresentaram comportamento hidrodinâmico próximo à mistura completa. Considerando os resultados obtidos nos ensaios de hidrodinâmica e a influência da velocidade de agitação no desempenho de ASBBR observada por Cubas et al. (2004) optou-se pela 
aplicação da freqüência de agitação de 300 rpm para a operação dos reatores sulfetogênicos.

\subsection{Desempenho do Reator com Espuma de Poliuretano (RE) no Tratamento}

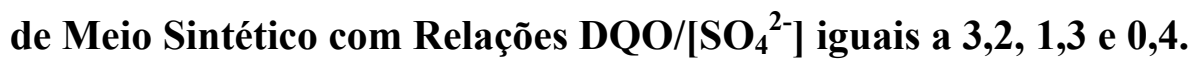

\subsubsection{Alimentação com Relação DQO/[ $\left[\mathrm{SO}_{4}{ }_{4}^{2-}\right]$ Igual a 3,2}

A Figura 5.38 apresenta as variações das eficiências em remoção de sulfato e de DQO no reator RE durante os ciclos tratando meio sintético com relação $\mathrm{DQO} /\left[\mathrm{SO}_{4}{ }^{2-}\right]$ igual a 3,2 .

Nessa condição, o reator RE apresentou estabilidade em redução de sulfato a partir do $61^{\circ}$ ciclo, com eficiência média de $94 \pm 4 \%$. A eficiência média em remoção de DQO foi $67 \pm 9 \%$ a partir do $61^{\circ}$ ciclo. Os valores das variáveis $\mathrm{pH}, \mathrm{AT}, \mathrm{AB}$ e ATV medidos no efluente desse reator, foram: 7,3 $\pm 0,2,659 \pm 75$ mg.L ${ }^{-1}, 564 \pm 104$ mg. $\mathrm{L}^{-1}$ e $146 \pm 28 \mathrm{mg} . \mathrm{L}^{-1}$, respectivamente. Observou-se que a variação na DQO remanescente foi proporcional a variação da concentração de ATV, como mostra a Figura 5.39.

O acúmulo de ATV foi, provavelmente, devido a inibição de BRS e AM acetoclásticas pelo sulfeto produzido. Entre os $42^{\circ}$ e $68^{\circ}$ ciclos, a [ST] média foi $47 \pm 19 \mathrm{mg} . \mathrm{L}^{-1}$ e o $\mathrm{pH}$ foi $7,0 \pm 0,3$. Dessa forma, as concentrações de sulfeto de hidrogênio como $\mathrm{H}_{2} \mathrm{~S}$ e $\mathrm{HS}^{-}$, calculadas pela equação 5.7 foram $19 \pm 11 \mathrm{mg} . \mathrm{L}^{-1} \mathrm{e}$ $28 \pm 14 \mathrm{mg} . \mathrm{L}^{-1}$, respectivamente.

$p H-p k_{1}=\log \frac{\left[H S^{-}\right]}{\left[H_{2} S\right]}$

A equação 5.7 foi deduzida a partir da lei do equilíbrio químico para o $\mathrm{H}_{2} \mathrm{~S}$, representada na equação 5.8 . $\mathrm{O}$ valor da constate de equilíbrio $\left(\mathrm{k}_{1}\right)$, a $30^{\circ} \mathrm{C}$, utilizado nesse cálculo foi $13,05 \times 10^{-8}$ (adaptado de LAWRENCE E MCCARTY, 1966) e $p k_{1}$ corresponde ao antilogaritmo, na base 10 , de $k_{1}$.

$$
k_{1}=\frac{\left[H S^{-}\right]\left[H^{+}\right]}{\left[H_{2} S\right]}
$$




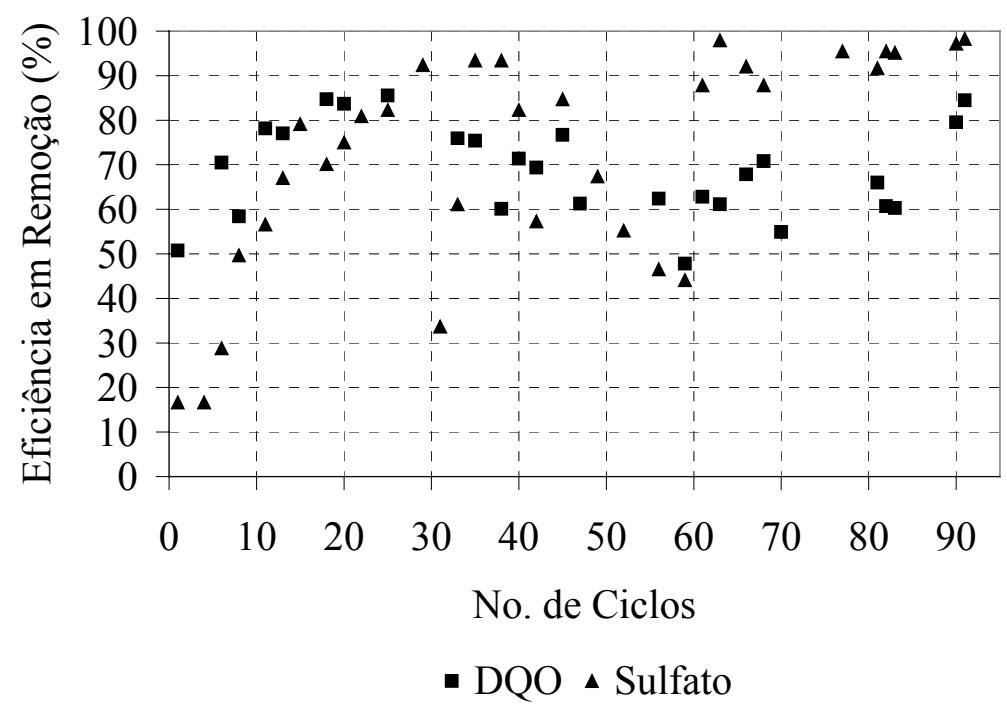

Figura 5.38. Eficiências de Remoção de Sulfato e DQO no Reator com Espuma de Poliuretano Tratando Meio Sintético com Relação DQO/[SOS $\left.{ }^{2-}\right]$ igual a3,2.

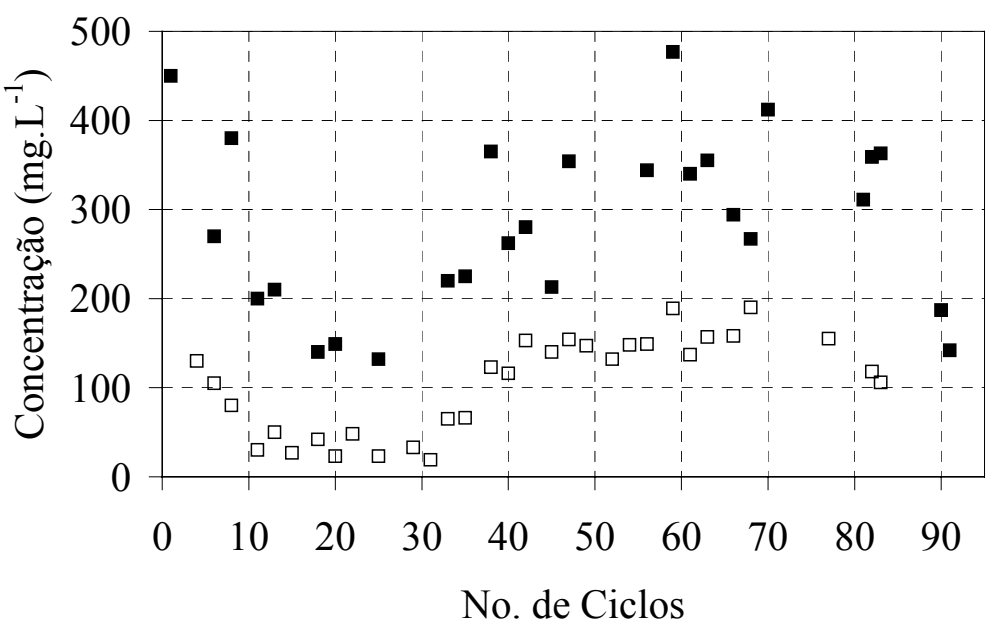

- DQO $\square$ ATV

Figura 5.39. DQO e Concentrações de Ácidos Totais Voláteis no Efluente do Reator Contendo Espuma de Poliuretano, Tratando Meio Sintético com Relação $\mathrm{DQO} /\left[\mathrm{SO}_{4}{ }^{2-}\right]$ igual a3,2.

De acordo com LANGE (1978), a constante de solubilidade do $\mathrm{H}_{2} \mathrm{~S}$ a $30^{\circ} \mathrm{C}$ é $2980 \mathrm{mg} \cdot \mathrm{L}^{-1} \cdot \mathrm{atm}^{-1}$. Utilizando-se a lei de Henry $\left(C=H^{\prime} \times p\right)$ onde: $C$ é a concentração do gás em mg. $\mathrm{L}^{-1}, p$ é a pressão parcial do gás em atm, e $H^{\prime}$ é uma 
constante que expressa a solubilidade do gás em mg. $\mathrm{L}^{-1} \cdot \mathrm{atm}^{-1}$, concluiu-se que o $\mathrm{H}_{2} \mathrm{~S}_{(\mathrm{g})}$ produzido foi, praticamente, dissolvido no líquido.

MAILACHERUVU et al. (1996) observaram que, dos microrganismos constituintes do consórcio microbiano anaeróbio, as BRS acetoclásticas foram os mais sensíveis à presença de sulfeto, seguidos pelos fermentadores de ácido propiônico e arqueas metanogênicas acetoclásticas. Segundo esses autores,as BRS são inibidas por altas concentrações de sulfeto total dissolvido e arqueas metanogênicas por altas concentrações de $\mathrm{H}_{2} \mathrm{~S}$. Com base nessas observações sugerese a operação de reatores biológicos, com a finalidade de remoção de sulfato, com $\mathrm{pH}$ abaixo de 7,0 ou mantendo-se a fração de sulfeto total dissolvido abaixo de 50\%. Isso faz com que sulfeto de hidrogênio seja naturalmente removido por "stripping", mantendo as concentrações de sulfeto total dissolvido em baixos níveis no sistema.

A [ST] média, representada pela soma do sulfeto dissolvido ( $\left.\mathrm{HS}^{-}\right)$e $\mathrm{H}_{2} \mathrm{~S}$ no efluente, correspondeu a $45 \%$ da quantidade que deveria ser, teoricamente, observada em função da quantidade de sulfato reduzida $\left(272 \mathrm{mg} \cdot \mathrm{L}^{-1}\right)$. A maior parte de sulfeto não quantificada foi oxidada à enxofre elementar. Esse fato pôde ser observado pela deposição de enxofre na parte superior do cesto que continha o material suporte e na tampa do reator, sendo posteriormente comprovado, analiticamente, por fluorescência de raios X com energia dispersiva (EDXRF). A oxidação parcial do sulfeto ocorreu devido à entrada de ar durante as operações de descarga do reator em cada batelada ou por ação microbiana. A quantidade de enxofre na forma de sulfeto utilizada na biossíntese de sistemas anaeróbios pode ser desprezível, considerando a baixa produção de biomassa nesses sistemas. Outra parte do sulfeto foi liberada na forma gasosa, porém, a concentração de $\mathrm{H}_{2} \mathrm{~S}$ e o volume do biogás produzido foram baixos, ou seja, $<1$ ppm e $480 \mathrm{~mL}$. Além de sulfeto de hidrogênio, detectou-se metano em baixa concentração $\left(11 \mathrm{mg} \cdot \mathrm{L}^{-1}\right)$. Esse resultado indica que a sulfetogênese foi o processo predominante no reator RE durante o tratamento de água residuária sintética com relação $\mathrm{DQO} /\left[\mathrm{SO}_{4}{ }^{2-}\right]$ igual a 3,2 .

\subsubsection{Alimentação com Relação DQO/[ $\left.\mathrm{SO}_{4}{ }_{4}^{2-}\right]$ Igual a 1,3.}

A Figura 5.40 apresenta as eficiências em remoção de sulfato e de DQO observadas ao longo dos ciclos operacionais, realizados no reator RE tratando meio sintético com relação $\mathrm{DQO} /\left[\mathrm{SO}_{4}{ }^{2-}\right]$ igual a 1,3 . Nessa condição, o reator apresentou 
estabilidade em redução de sulfato a partir do $57^{\circ}$ ciclo, com eficiência média de $96 \pm 3 \%$. A eficiência média em remoção de DQO a partir do $57^{\circ}$ ciclo foi $61 \pm 9 \%$. Os valores das variáveis $\mathrm{pH}, \mathrm{AT}, \mathrm{AB}$ e $\mathrm{ATV}$, medidos no efluente do reator foram: 7,0 0 0,2, $912 \mathrm{mg} . \mathrm{L}^{-1}, 827 \pm 60 \mathrm{mg} . \mathrm{L}^{-1}$ e $120 \pm 85 \mathrm{mg} . \mathrm{L}^{-1}$, respectivamente.

A [ST] média foi $82 \pm 41 \mathrm{mg} \cdot \mathrm{L}^{-1}$. De acordo com a equação 5.7 , as concentrações de $\mathrm{H}_{2} \mathrm{~S}$ e $\mathrm{HS}^{-}$foram: $43 \pm 21 \mathrm{mg} . \mathrm{L}^{-1}$ e $40 \pm 23 \mathrm{mg} . \mathrm{L}^{-1}$, respectivamente.

Como ocorreu no tratamento de meio sintético com relação $\mathrm{DQO} /\left[\mathrm{SO}_{4}{ }^{2-}\right]$ igual a 3,2, mais de $50 \%$ da quantidade de sulfeto, teoricamente produzida, não foi quantificada no efluente, provavelmente devido à oxidação parcial do sulfeto a enxofre elementar. Não foi detectado metano em amostras do biogás sugerindo que o reator tornou-se completamente sulfetogênico.

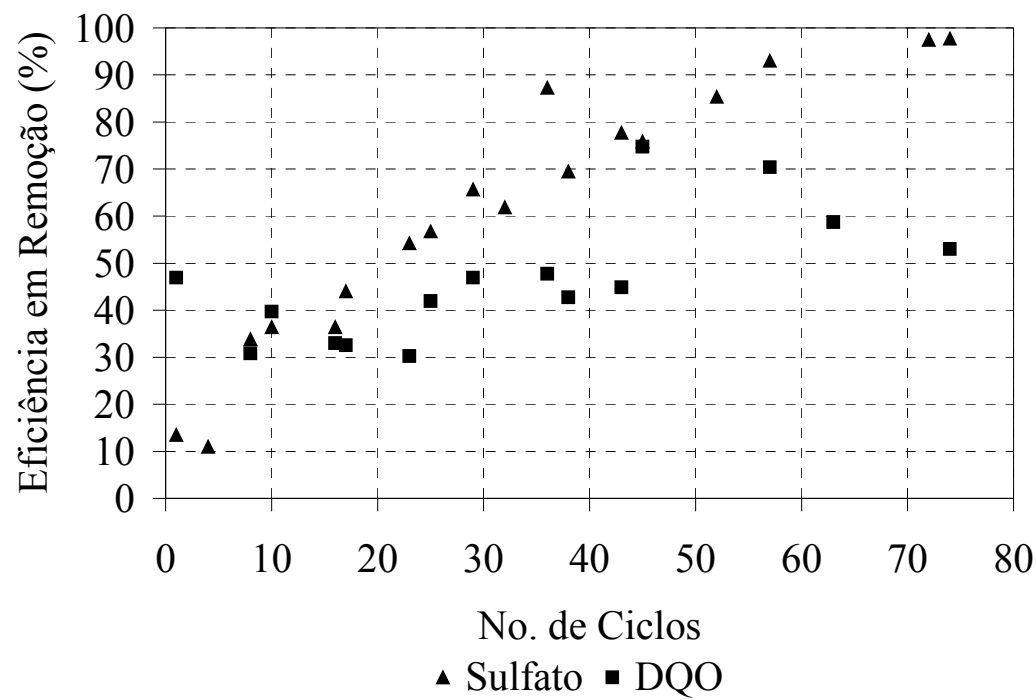

Figura 5.40. Eficiências de Remoção de Sulfato e de DQO no Reator com Espuma de Poliuretano Tratando Meio Sintético com Relação DQO/[ $\left.\mathrm{SO}_{4}{ }^{2-}\right]$ igual a1,3.

\subsubsection{Alimentação com Relação DQO/[ $\left.\mathrm{SO}_{4}{ }^{2-}\right]$ Igual a 0,4.}

A Figura 5.41 apresenta as eficiências em remoção de sulfato e de DQO do reator $\mathrm{RE}$ tratando meio sintético com relação $\mathrm{DQO} /\left[\mathrm{SO}_{4}{ }^{2-}\right]$ igual a 0,4 . Nessa condição, a estabilidade em redução de sulfato foi observada a partir do $38^{\circ}$ ciclo, com eficiência média de $31 \pm 6 \%$. A eficiência média em remoção de DQO a partir do $38^{\circ}$ ciclo foi $62 \pm 14 \%$. Os valores das variáveis $\mathrm{pH}, \mathrm{AT}, \mathrm{AB}$ e ATV, medidos no 
efluente foram: 7,8 $\pm 0,4, \quad 838 \pm 97 \mathrm{mg} . \mathrm{L}^{-1}, \quad 788 \pm 129 \mathrm{mg} . \mathrm{L}^{-1}$ e $69 \pm 61 \mathrm{mg} . \mathrm{L}^{-1}$, respectivamente.

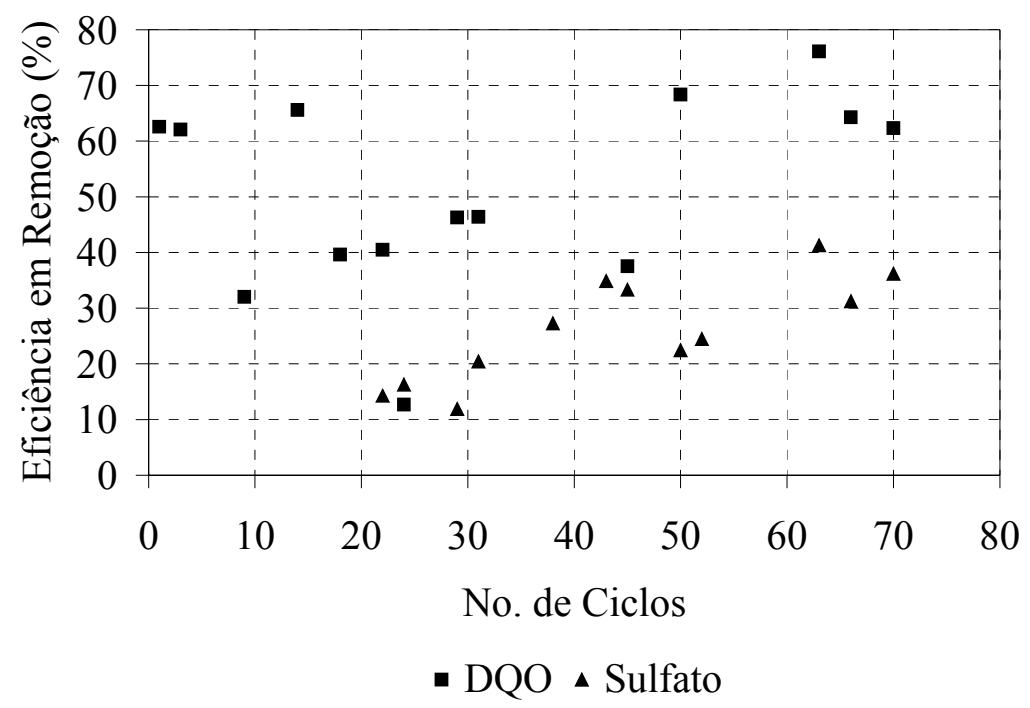

Figura 5.41. Eficiências de Remoção de Sulfato e de DQO no Reator com Espuma de Poliuretano Tratando Meio Sintético com Relação DQO/[ $\left.\mathrm{SO}_{4}{ }^{2-}\right]$ igual a0,4.

Nessa etapa do experimento, [ST] média no efluente do reator foi $120 \pm 15$ mg. $\mathrm{L}^{-1}$ e as concentrações de $\mathrm{HS}^{-}$e $\mathrm{H}_{2} \mathrm{~S}$ foram $105 \pm 13 \mathrm{mg} . \mathrm{L}^{-1}$ e $15 \pm 5 \mathrm{mg} . \mathrm{L}^{-1}$, respectivamente. A [ST] detectada no efluente do reator RE, nessa condição, correspondeu a 52\% da concentração teoricamente produzida, considerando a concentração de sulfato reduzida. Praticamente metade do sulfeto gerado foi, provavelmente, oxidado a enxofre elementar devido a entrada de ar no reator durante a descarga de efluente tratado ou por atividade microbiana. Nessa etapa do experimento não foi detectado metano em amostras do biogás indicando que o reator estava completamente sulfetogênico.

\subsubsection{Considerações Gerais sobre o Estudo do Processo de Biodessulfatação em} $\underline{\text { ASBBR Utilizando Espuma de Poliuretano como Material Suporte }}$

A Tabela 5.10 apresenta os valores médios das variáveis monitoradas no efluente do reator $\mathrm{RE}$ tratando meio sintético com relações $\mathrm{DQO} /\left[\mathrm{SO}_{4}{ }^{2-}\right]$ iguais a 3,2, 1,3 e 0,4 . 
A concentração média de ATV no efluente do reator RE quando este foi alimentado com meio sintético com relação $\mathrm{DQO} /\left[\mathrm{SO}_{4}{ }^{2-}\right]$ igual a 0,4 foi, significativamente, menor do que as concentrações observadas durante o tratamento de meio sintético com relações $\mathrm{DQO} /\left[\mathrm{SO}_{4}{ }^{2-}\right]$ iguais a 1,3 e 3,2. Salienta-se que as porcentagens de sulfeto de hidrogênio, como $\mathrm{H}_{2} \mathrm{~S}$, no efluente do reator RE quando este tratou meio sintético com relações $\mathrm{DQO} /\left[\mathrm{SO}_{4}{ }^{2-}\right]$ de 3,2 e 1,3 foram $41 \pm 15 \%$ e $54 \pm 10 \%$, respectivamente, do valor de [ST] em condição de estabilidade em remoção de sulfato. Quando a relação $\mathrm{DQO} /\left[\mathrm{SO}_{4}{ }^{2-}\right]$ do meio sintético foi diminuída para 0,4 observou-se que a porcentagem de $\mathrm{H}_{2} \mathrm{~S}$ dissolvido no efluente desse reator diminuiu para $13 \pm 4 \%$. Esse fato pode ter favorecido o consumo de Hac por microrganismos acetoclásticos.

Tabela 5.10. Valores Médios das Variáveis Monitoradas no Efluente do Reator Contendo Espuma de Poliuretano como Material Suporte.

\begin{tabular}{|c|c|c|c|}
\hline \multirow[b]{2}{*}{ Variáveis } & \multicolumn{3}{|c|}{ Relação DQO/[SOS $\left.{ }_{4}^{2-}\right]$} \\
\hline & 3,2 & 1,3 & 0,4 \\
\hline $\mathrm{pH}$ & $7,3 \pm 0,2$ & $7,0 \pm 0,2$ & $7,8 \pm 0,4$ \\
\hline Alcalinidade Total (mg. $\left.\mathrm{L}^{-1}\right)$ & $659 \pm 75$ & $912 \pm 0$ & $838 \pm 97$ \\
\hline Alcalinidade a Bicarbonato (mg. $\left.\mathrm{L}^{-1}\right)$ & $564 \pm 104$ & $827 \pm 60$ & $788 \pm 129$ \\
\hline Ácidos Totais Voláteis (mg.L $\left.\mathrm{L}^{-1}\right)$ & $146 \pm 28$ & $120 \pm 85$ & $40 \pm 20$ \\
\hline Sulfato $\left(\mathrm{mg} . \mathrm{L}^{-1}\right)$ & $18 \pm 11$ & $29 \pm 17$ & $1581 \pm 209$ \\
\hline Sulfeto Total (mg.L $\left.{ }^{-1}\right)$ & $40 \pm 15$ & $82 \pm 41$ & $120 \pm 14$ \\
\hline DQO (mg.L $\left.\mathrm{L}^{-1}\right)$ & $303 \pm 84$ & $389 \pm 81$ & $390 \pm 125$ \\
\hline Remoção de DQO (\%) & $67 \pm 9$ & $61 \pm 9$ & $62 \pm 15$ \\
\hline Remoção de Sulfato (\%) & $94 \pm 4$ & $96 \pm 3$ & $31 \pm 6$ \\
\hline
\end{tabular}




\subsection{Desempenho do Reator com Carvão Vegetal (RC) no Tratamento de Meio

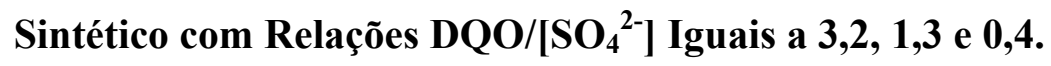

\subsubsection{Alimentação com Relação DQO/[ $\left.\mathrm{SO}_{4}{ }_{4}^{2-}\right]$ Igual a 3,2}

A Figura 5.42 apresenta a variação das eficiências em remoção de sulfato e de DQO ao longo dos ciclos realizados no reator $\mathrm{RC}$ tratando meio sintético com relação $\mathrm{DQO} /\left[\mathrm{SO}_{4}{ }^{2-}\right]$ igual a 3,2 .

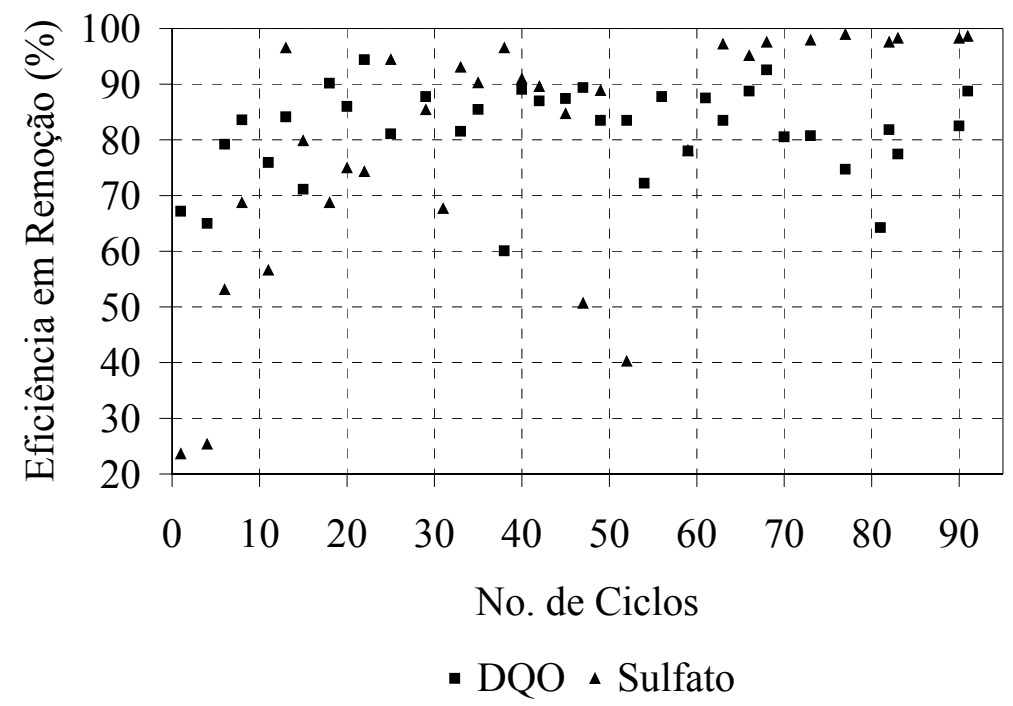

Figura 5.42. Eficiências em Remoção de Sulfato e de DQO no Reator com Carvão Vegetal Tratando Meio Sintético com Relação DQO/[ $\left.\mathrm{SO}_{4}{ }^{2-}\right]$ igual a3,2.

Nessa condição, o reator RC apresentou estabilidade em redução de sulfato a partir do $63^{\circ}$ ciclo, com eficiência média de $98 \pm 1 \%$. A eficiência média em remoção de DQO foi de $81 \pm 8 \%$. Os valores das variáveis $\mathrm{pH}, \mathrm{AT}, \mathrm{AB}$ e $\mathrm{ATV}$, no efluente, foram: 7,2 $\pm 0,2, \quad 779 \pm 99 \mathrm{mg} . \mathrm{L}^{-1}, \quad 746 \pm 94 \mathrm{mg} . \mathrm{L}^{-1}$ e $47 \pm 19 \mathrm{mg} . \mathrm{L}^{-1}$, respectivamente. Observou-se que a variação na DQO remanescente foi proporcional a variação de ATV (Figura 5.42). 


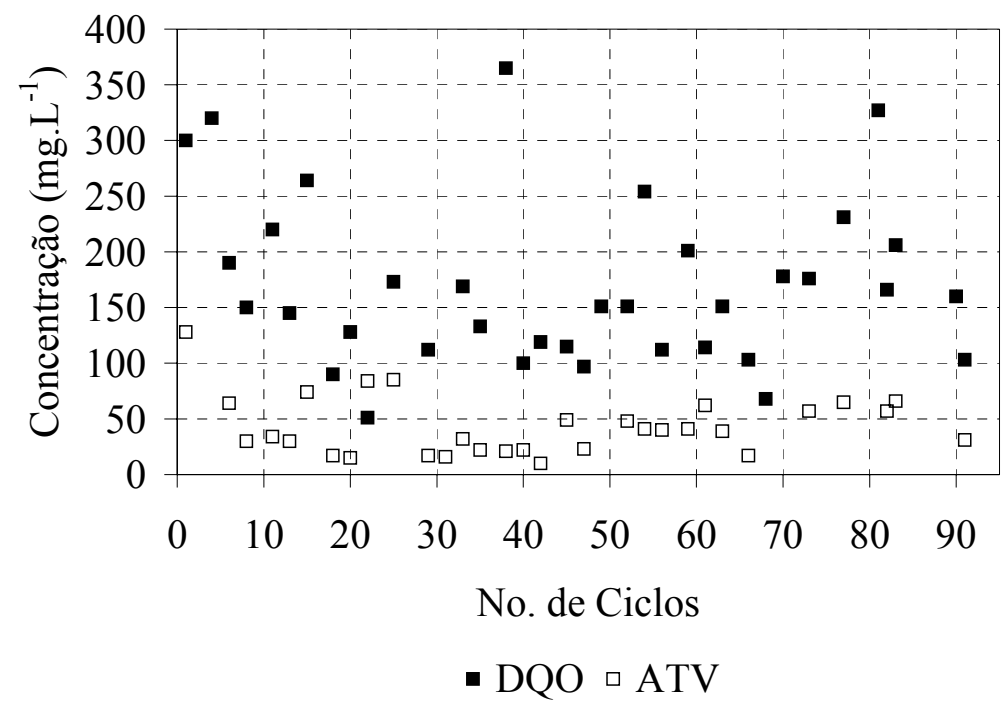

Figura 5.43. Valores de DQO e Concentração de Ácidos Totais Voláteis em Função dos Ciclos Operacionais do Reator RC Tratando Meio Sintético com Relação

$$
\mathrm{DQO} /\left[\mathrm{SO}_{4}{ }^{2-}\right] \text { igual a3,2. }
$$

As baixas concentrações de ATV observadas no efluente do reator RC podem ser devidas a: (i) a matéria orgânica pode ter sido, preferencialmente, degradada pela via não acetogênica pelas BRS e BA - (ii) microrganismos acetoclásticos consumiram Hac excretado pelas BRS e BA. Esses resultados indicam que não houve toxicidade pelo sulfeto, ainda que a [ST] média nessa condição de alimentação $\left(44 \pm 16\right.$ mg. $\left.\mathrm{L}^{-1}\right)$ tenha sido igual à observada no reator RE, o qual acumulou Hac. As concentrações de sulfeto de hidrogênio como $\mathrm{H}_{2} \mathrm{~S}$ e $\mathrm{HS}^{-}$foram: $26 \pm 7 \mathrm{mg}$. $\mathrm{L}^{-1}$ (59\% [ST]) e $18 \pm 10 \mathrm{mg} . \mathrm{L}^{-1}(41 \%$ [ST]), respectivamente.

O volume médio diário e a concentração média de metano do biogás produzido, em três ciclos distintos foram $260 \mathrm{~mL}$ e $110 \mathrm{mg} . \mathrm{L}^{-1}$, respectivamente, ou seja, dez vezes superior à concentração detectada no biogás do reator RE. Uma explicação para essa constatação é o possível aprisionamento de gás nos poros da espuma de poliuretano possibilitando a utilização de metano como doador de elétrons nas reações bioquímicas ocorrendo nesse reator. No carvão esse fenômeno pode não ter ocorrido ou foi menos intenso devido, por exemplo, a sua porosidade e diâmetro médio dos poros, serem menores do que em PU. A porosidade e diâmetro médio dos poros em PU foram $0,92 \mu \mathrm{m}$ e $543 \mu \mathrm{m}$ e em CV 0,43 e 1,9 $\mu \mathrm{m}$, respectivamente. 


\subsubsection{Alimentação com Relação DQO/[ $\left[\mathrm{SO}_{4}{ }_{4}^{2-}\right]$ Igual a 1,3}

A Figura 5.44 apresenta a variação das eficiências em remoção de sulfato e de DQO ao longo dos ciclos realizados no reator RC tratando meio sintético com relação $\mathrm{DQO} /\left[\mathrm{SO}_{4}{ }^{2-}\right]$ igual a 1,3 .

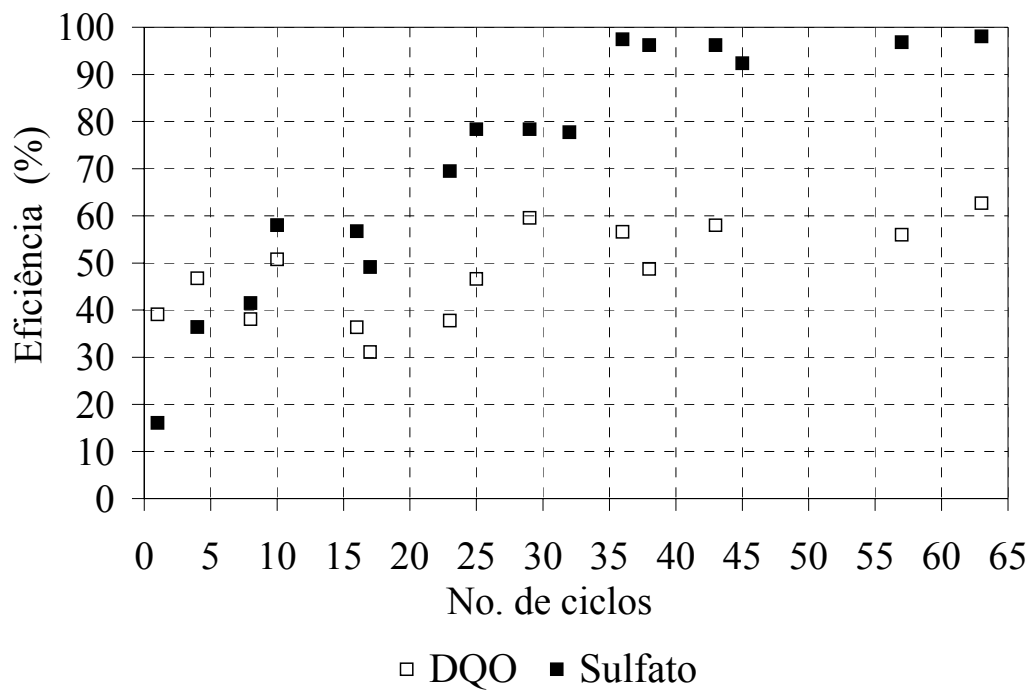

Figura 5.44. Eficiências em Remoção de Sulfato e de DQO no Reator com Carvão Vegetal Tratando Meio Sintético com Relação DQO/[ $\left.\mathrm{SO}_{4}{ }^{2-}\right]$ igual a1,3.

Nessa condição o reator RC apresentou estabilidade em redução de sulfato a partir do $36^{\circ}$ ciclo com eficiência média de $96 \pm 2 \%$. A partir desse ciclo, a eficiência média em remoção de DQO a partir do $36^{\circ}$ ciclo foi de $56 \pm 5 \%$. Os valores das variáveis $\mathrm{pH}, \mathrm{AT}, \mathrm{AB}$ e ATV, no efluente foram: 7,0 $40,1,907 \pm 81 \mathrm{mg} . \mathrm{L}^{-1}, 760 \pm 103$ mg. $L^{-1}$ e $119 \pm 26$ mg. $L^{-1}$, respectivamente.

Nessa condição a concentração de ATV foi maior do que a observada no efluente do reator $\mathrm{RC}$ tratando meio sintético com relação $\mathrm{DQO} /\left[\mathrm{SO}_{4}{ }^{2-}\right]$ de 3,2 . É possível que substratos orgânicos tenham sido oxidados parcialmente por BRS e o Hac foi acumulando, provavelmente devido à inibição dos microrganismos acetoclásticos, em decorrência da presença de sulfeto. A [ST] foi igual a 99 \pm 39 mg. $\mathrm{L}^{-1}$, sendo que $51 \%$ do sulfeto de hidrogênio era como $\mathrm{H}_{2} \mathrm{~S}$.

Não foi detectado metano em amostras de biogás. Isso indica que $\mathrm{CH}_{4}$ pode ter sido utilizado pelas BRS como doador de elétrons, conforme a equação 4.9, ou 
não ter sido produzido devido à inibição das AM. Nesse caso, o reator tornou-se completamente sulfetotogênico.

$\mathrm{CH}_{4}+\mathrm{SO}_{4}^{2-} \rightarrow \mathrm{CO}_{2}+\mathrm{S}^{2-}+2 \mathrm{H}_{2} \mathrm{O}$

\subsubsection{Alimentação com Relação DQO/[ $\left[\mathrm{SO}_{4}{ }^{2-}\right]$ Igual a 0,4}

A Figura 5.45 apresenta a variação das eficiências em remoção de sulfato e DQO ao longo dos ciclos realizados no reator $\mathrm{RC}$, tratando meio sintético com relação $\mathrm{DQO} /\left[\mathrm{SO}_{4}{ }^{2-}\right]$ igual a 0,4 .

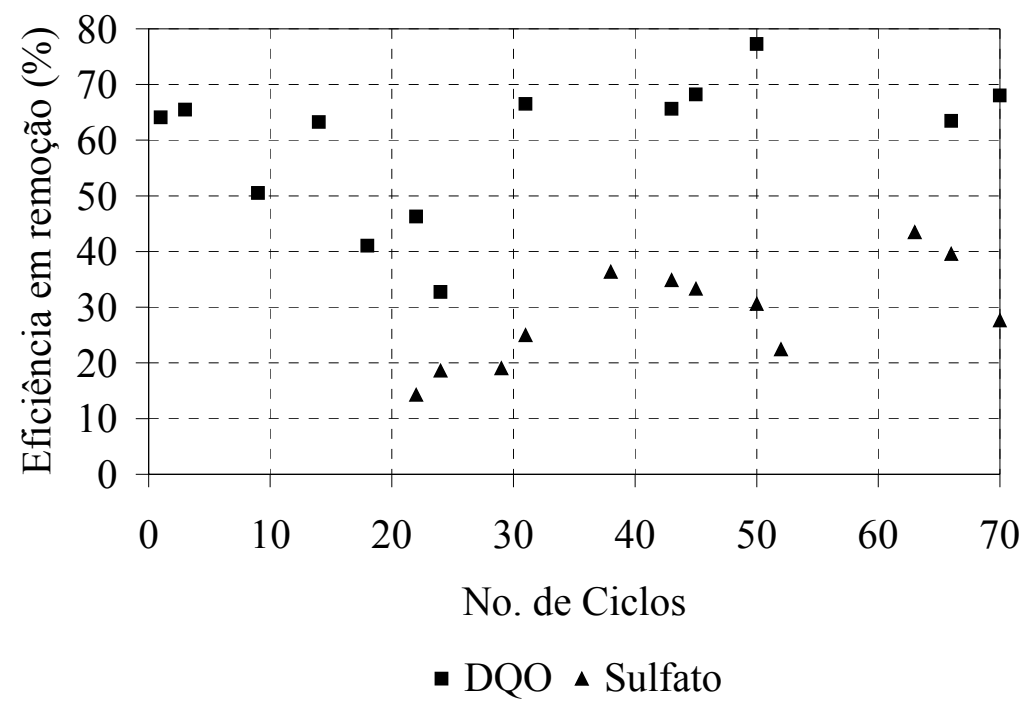

Figura 5.45. Eficiências em Remoção de Sulfato e de DQO no Reator com Carvão Vegetal Tratando Meio Sintético com Relação DQO/[SOS$\left.{ }^{2-}\right]$ igual a 0,4.

A estabilidade da eficiência em redução de sulfato nessa condição foi observada a partir do $38^{\circ}$ ciclo com eficiência média de $34 \pm 7 \%$. A eficiência média em remoção de DQO foi de $69 \pm 5 \%$. Os valores das variáveis $\mathrm{pH}, \mathrm{AT}, \mathrm{AB}$ e ATV, no efluente, foram: $8,1 \pm 0,3,1163 \pm 222 \mathrm{mg} . \mathrm{L}^{-1}, 1132 \pm 230 \mathrm{mg} . \mathrm{L}^{-1}$ e $43 \pm 22 \mathrm{mg} . \mathrm{L}^{-1}$, respectivamente. A eficiência em remoção de DQO foi praticamente igual às eficiências observadas no tratamento de meio sintético com relações $\mathrm{DQO} /\left[\mathrm{SO}_{4}{ }^{2-}\right]$ iguais a 3,2 e 1,3. Esse fato indica que o processo sulfetogênico foi limitado pela disponibilidade de doador de elétrons. A baixa concentração de ATV observada no efluente pode ser devida ao consumo de Hac por BRS e por AM. Nesse caso, não ocorreu toxidade devida ao sulfeto. Isso pode ser explicado pela predominância de 
sulfeto de hidrogênio como $\mathrm{HS}^{-}$que é menos tóxico para microrganismos acetoclásticos (MAILLACHERUVU et al., 1996).

A [ST] observada no efluente foi $114 \pm 20 \mathrm{mg} . \mathrm{L}^{-1}$ e somente $7 \%$ do sulfeto de hidrogênio estava presente como $\mathrm{H}_{2} \mathrm{~S}$. Como ocorreu no tratamento de meio sintético com relação $\mathrm{DQO} /\left[\mathrm{SO}_{4}{ }^{2-}\right]$ igual a 1,3 , nessa condição não foi detectado metano. Isso pode ser devido à baixa produção desse gás associada a sua utilização como doador de elétrons pelas BRS ou a inibição de AM.

\subsection{Considerações Gerais Sobre o Estudo do Processo de Biodessulfatação em ASBBR Utilizando Carvão Vegetal como Material Suporte}

A Tabela 5.11 apresenta os valores médios das variáveis monitoradas no efluente do reator $\mathrm{RC}$ tratando meio sintético com diferentes relações $\mathrm{DQO} /\left[\mathrm{SO}_{4}{ }^{2-}\right]$ iguais a $3,2,1,3$ e 0,4 .

Tabela 5.11. Valores Médios das Variáveis Monitoradas no Efluente do Reator Contendo Carvão Vegetal como Material Suporte.

\begin{tabular}{|c|c|c|c|}
\hline \multirow[b]{2}{*}{ Variáveis } & \multicolumn{3}{|c|}{ Relação DQO/[SOS$\left.{ }^{2-}\right]$} \\
\hline & 3,2 & 1,3 & 0,4 \\
\hline $\mathrm{pH}$ & $7,2 \pm 0,2$ & $7,0 \pm 0,1$ & $8,1 \pm 0,3$ \\
\hline Alcalinidade Total $\left(\mathrm{mg} \cdot \mathrm{L}^{-1}\right)$ & $779 \pm 99$ & $907 \pm 81$ & $1163 \pm 222$ \\
\hline Alcalinidade a Bicarbonato (mg. $\left.\mathrm{L}^{-1}\right)$ & $746 \pm 94$ & $760 \pm 103$ & $1132 \pm 230$ \\
\hline Ácidos Totais Voláteis (mg. $\left.\mathrm{L}^{-1}\right)$ & $47 \pm 19$ & $119 \pm 26$ & $43 \pm 22$ \\
\hline Sulfato $\left(\mathrm{mg} \cdot \mathrm{L}^{-1}\right)$ & $7 \pm 3$ & $26 \pm 15$ & $1531 \pm 209$ \\
\hline Sulfeto $\left(\mathrm{mg} . \mathrm{L}^{-1}\right)$ & $44 \pm 16$ & $110 \pm 23$ & $114 \pm 20$ \\
\hline DQO (mg.L $\left.{ }^{-1}\right)$ & $170 \pm 70$ & $415 \pm 47$ & $291 \pm 27$ \\
\hline Remoção de DQO (\%) & $81 \pm 8$ & $56 \pm 5$ & $69 \pm 5$ \\
\hline Remoção de Sulfato (\%) & $98 \pm 1$ & $96 \pm 2$ & $34 \pm 7$ \\
\hline
\end{tabular}

A concentração média de ATV, no efluente do reator $\mathrm{RC}$, quando este foi alimentado com meio sintético com relação $\mathrm{DQO} /\left[\mathrm{SO}_{4}{ }^{2-}\right]$ igual a 0,4 foi praticamente 
igual ao valor observado durante o tratamento de meio sintético com relação $\mathrm{DQO} /\left[\mathrm{SO}_{4}{ }^{2-}\right]$ de 3,2 (Tabela 5.2).

A eficiência em remoção de DQO no reator $\mathrm{RC}$ tratando meio sintético com relação $\mathrm{DQO} /\left[\mathrm{SO}_{4}{ }^{2-}\right]$ igual a 0,4 foi maior do que a obtida tratando meio sintético com relação $\mathrm{DQO} /\left[\mathrm{SO}_{4}{ }^{2-}\right]$ igual a 1,3 . Por outro lado, nessas condições observou-se significativa perda de eficiência em relação a redução de sulfato quando a relação $\mathrm{DQO} /\left[\mathrm{SO}_{4}{ }^{2-}\right]$ foi diminuída. Concluiu-se que a disponibilidade de doadores de elétrons pode ter sido o fator limitante do processo sulfetogênico. Outro fator que pode ter inibido o processo sulfetogênico é a [ST] dissolvido (107 mg.. $\left.{ }^{-1}\right)$ ter correspondido a $93 \%$ da [ST]. Baseado nas conclusões de MAILACHERUVU et al. (1993) essa condição provoca inibição de BRS. Todavia, a [ST] no efluente foi bastante inferior aos valores citados na literatura como tóxicos para microrganismos anaeróbios (ISA et al., 1986; PAULA JR. (1992).

\subsection{Comparação do Desempenho dos Reatores com Espuma de Poliuretano e Carvão Vegetal.}

Os desempenhos dos reatores $\mathrm{RE}$ e $\mathrm{RC}$ em relação a remoção de $\mathrm{DQO}$ e redução de sulfato, considerando as concentrações remanescentes quando os reatores foram alimentados com meio sintético com relação $\mathrm{DQO} /\left[\mathrm{SO}_{4}{ }^{2-}\right]$ de 3,2 , foram comparados estatisticamente por teste de hipótese ("t de Student"). O teste estatístico foi altamente significativo $(\mathrm{p}<0,001)$ para os dados de DQO remanescente e indicaram que o reator RC foi mais eficiente na remoção de DQO do que o reator RE. Em relação à redução de sulfato, o teste foi significativo em nível de $5 \%$ $(p<0,05)$, indicando melhor desempenho do reator RC. O melhor desempenho em redução de sulfato do $\mathrm{ASBBR}$ utilizando $\mathrm{CV}$ como $\mathrm{MS}$ pode ser devido a maior quantidade absoluta de biomassa retida, fato observado no estudo de adesão (Figura 5.2). Além disso, os resultados obtidos por FISH no estudo de adesão indicaram maior quantidade de BRS aderida em CV do que em PU (Figura 5.3).

Aos dados de DQO (paramétricos) e concentração de sulfato (não paramétricos) remanescentes, durante a alimentação dos reatores com meio sintético com relação $\mathrm{DQO} /\left[\mathrm{SO}_{4}{ }^{2-}\right]$ de 1,3, aplicou-se os testes de hipóteses: "t de Student" e "Mann-Whitney”, respectivamente. Os testes estatísticos aplicados não foram 
significativos em nível de $5 \%(p>0,05)$ indicando que os reatores tiveram desempenhos iguais em remoção de DQO e sulfato.

Aos dados obtidos para $\left[\mathrm{SO}_{4}{ }^{2-}\right]$ e DQO, remanescentes nos reatores tratando meio sintético com relação $\mathrm{DQO} /\left[\mathrm{SO}_{4}{ }^{2-}\right]$ de 0,4 , foi aplicado o teste "t de Student", o qual não foi significativo em nível de $5 \%(\mathrm{p}>0,05)$ para as duas variáveis, indicando que os reatores tiveram desempenhos iguais em remoção de DQO e redução de sulfato.

\subsection{Retenção de Biomassa e Aspectos Microbiológicos}

\subsubsection{Biomassa no Inóculo}

O lodo utilizado como inóculo apresentou concentração média de SSV igual a $41.000 \mathrm{mg} . \mathrm{L}^{-1}$. A Tabela 5.12 e as Figuras 5.46 e 5.47 apresentam as morfologias observadas no inóculo por microscopia ótica.

Tabela 5.12. Morfologias Observadas no Inóculo e Freqüências.

\begin{tabular}{cc}
\hline \multicolumn{1}{c}{ Morfologias } & Freqüência Observada \\
\hline Arqueas Metanogênicas & ++ \\
- Arranjos Semelhantes a Methanosarcina sp. & ++++ \\
- Filamento Semelhante a Methanosaeta sp. & ++++ \\
- Bacilos fluorescentes & + \\
Bactérias & +++ \\
- Bacilos com extremidades arredondadas & ++++ \\
- Bacilos curvos (víbrios) & ++ \\
- Bacilos delgados & + \\
- Bacilos ovalados & ++ \\
- Cocos & Filamentos
\end{tabular}

$(++++)$ predominantes, $(+++)$ freqüentes, $(++)$ pouco freqüentes, $(+)$ raros, $(-)$ não foram observados. 

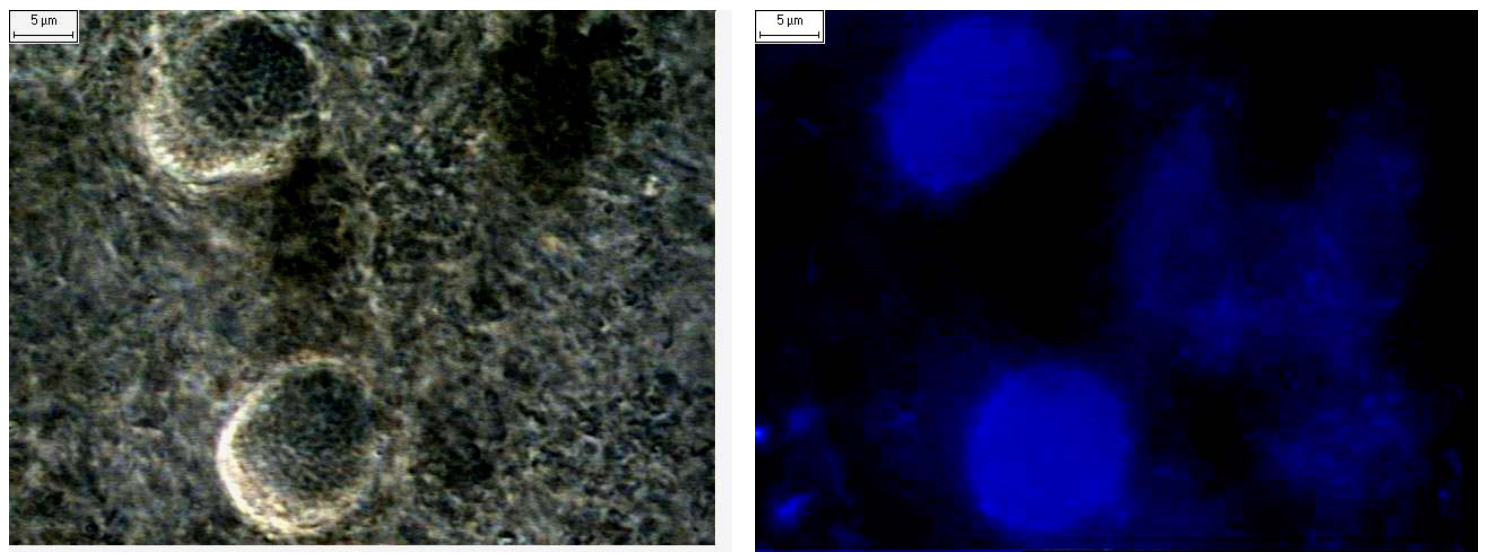

Figura 5.46. Morfologias Semelhantes a Arqueas Metanogênicas, Observadas no

Inóculo por Microscopia Ótica. (A) Arranjos Semelhantes a Methanosarcina sp.

Observados a Luz Comum; (B) Arranjos Semelhantes a Methanosarcina sp. e Bacilos Observados com Fluorescência.

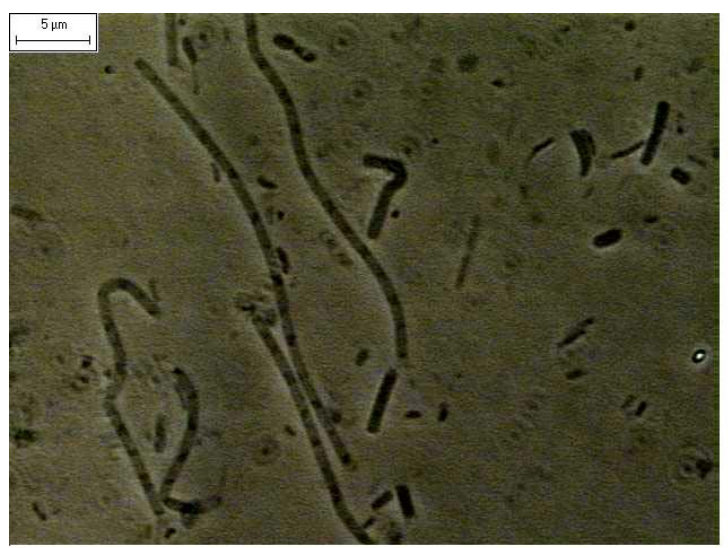

A

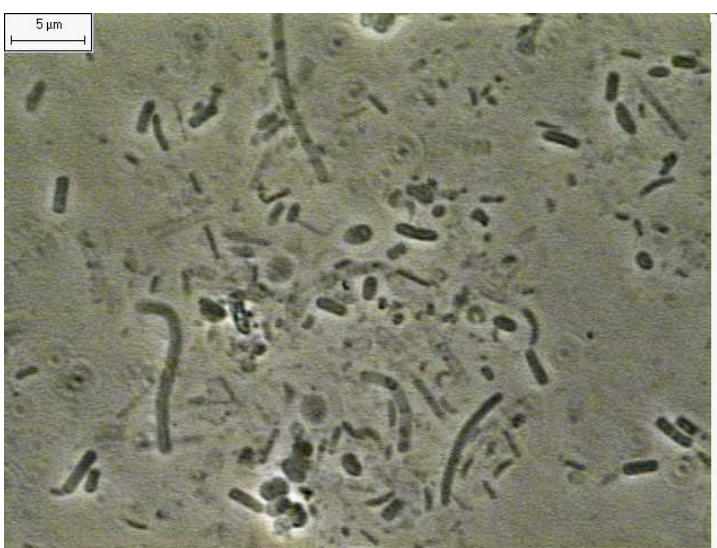

$\mathrm{B}$

Figura 5.47. Morfologias Observadas por Microscopia Ótica com Luz Comum no Inóculo. (A) Filamentos Semelhantes a Methanosaeta.sp., Bacilos com Extremidades Arredondadas. (B) Bacilos Ovalados, Cocos, Bacilos Curvos (Víbrios).

O inóculo apresentou considerável diversidade microbiana, característica de cultura mista de microrganismos anaeróbios, com espécies pertencentes aos Domínios Arquea e Bactéria, incluindo BRS. Portanto, o lodo proveniente de reator UASB tratando água residuária de abatedouro de aves foi adequado na aplicação como precursor para formação de biofilme e estudo do processo sulfetogênico nos ASBBR(s), com biomassa imobilizada em PU e CV. 
Os resultados obtidos por FISH, no inóculo, indicaram predomínio de microrganismos pertencentes ao Domínio Archaea (59,5\% das células coradas com DAPI) sobre os membros do Domínio Bactéria (44,8\%), como pode ser observado na Figura 5.48 (HIRASAWA et al., 2003).

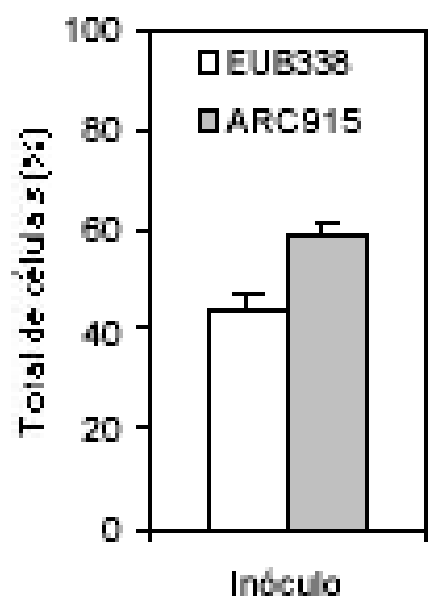

Figura 5.48. Composição da comunidade microbiana presente no inóculo. As porcentagens celulares são representadas pela quantidade de RNAr 16S microbiano para os membros pertencentes ao Domínios Bactéria (EUB338) e Archaea (Arc915) (HIRASAWA et al., 2003).

\subsubsection{Biomassa no Reator com Espuma de Poliuretano}

Durante o período abrangendo do $1^{\circ}$ ao $30^{\circ}$ ciclos, adicionou-se inóculo ao meio sintético. Nas fases em que o reator foi alimentado com meio sintético com relações DQO/[ $\left.\mathrm{SO}_{4}{ }^{2-}\right]$ iguais a 3,2, 1,3, e 0,4, as concentrações médias de SSV afluente foram: $406 \mathrm{mg} . \mathrm{L}^{-1}, 263 \mathrm{mg} . \mathrm{L}^{-1} \mathrm{e}, 391 \mathrm{mg} . \mathrm{L}^{-1}$, respectivamente. O volume médio de lodo adicionado em cada fase de operação, foi $255 \mathrm{~mL}$, correspondendo a $5 \%$ do volume útil do reator. A partir do $31^{\circ}$ ciclo suspendeu-se a adição de inóculo em todas as fases de operação e a concentração média de SSV no afluente, nas três fases, foi de $91 \mathrm{mg} . \mathrm{L}^{-1}$. As concentrações médias de SSV no efluente foram: 61 $\mathrm{mg} . \mathrm{L}^{-1}, 55 \mathrm{mg} . \mathrm{L}^{-1}$, e $50 \mathrm{mg} . \mathrm{L}^{-1}$, quando o reator RE foi alimentado com meio sintético com relações DQO/[ $\left.\mathrm{SO}_{4}{ }^{2-}\right]$ iguais a 3,2, 1,3, e 0,4, respectivamente. Esses resultados indicaram que houve boa retenção de microrganismos constituintes do inóculo no reator RE. A Tabela 5.13 apresenta três formas de quantificação da 
biomassa aderida no material suporte (MS) do reator RE: quantidade específica (gSSV.gMS $\left.{ }^{-1}\right)$, quantidade total em massa (gSSV), e concentração (mgSSV.L $\left.{ }^{-1}\right)$.

Tabela 5.13. Quantificação da Biomassa Aderida em Espuma de Poliuretano no ASBBR

\begin{tabular}{|c|c|c|c|}
\hline Relação DQO/[SOS $\left.{ }^{2-}\right]$ & 3,2 & 1,3 & 0,4 \\
\hline $\mathrm{mgSSV} \cdot \mathrm{gMS}^{-1}$ & 583 & 424 & 540 \\
\hline gSSV & 29,2 & 21,2 & 26,5 \\
\hline $\operatorname{MgSSV} . L^{-1}$ & 5214 & 3786 & 4732 \\
\hline
\end{tabular}

MS - Material Suporte

A Tabela 5.14 apresenta a descrição das morfologias e suas respectivas freqüências, observadas em amostras de PU no reator RE operando em condição de estabilidade em redução de sulfato. A Figura 5.49 apresenta algumas das morfologias observadas.

Observou-se predomínio de bacilos ovalados quando o reator RE foi alimentado com meio sintético com relação $\mathrm{DQO} /\left[\mathrm{SO}_{4}{ }^{2-}\right]$ igual a 3,2 e 1,3. Entretanto, quando passou-se a tratar meio sintético com relação $\mathrm{DQO} /\left[\mathrm{SO}_{4}{ }^{2-}\right]$ igual a 0,4 houve predomínio de víbrios e diminuição na freqüência observada das demais morfologias. Os bacilos ovalados podem ser associados a Dessulfobulbus propionicus spp., com base na literatura (MADIGAN et al., 1997). Esses microrganismos oxidam propionato incompletamente a acetato. Dessa forma, a diminuição do número desses microrganismos observada quando o reator RE foi alimentado com meio sintético com relação $\mathrm{DQO} /\left[\mathrm{SO}_{4}{ }^{2-}\right]$ de 0,4 pode ser relacionada com a carência de propionato. De fato, quando o reator RE foi alimentado com meio sintético com relação $\mathrm{DQO} /\left[\mathrm{SO}_{4}{ }^{2-}\right]$ de 0,4 observou-se a menor concentração de ATV (Tabela 5.1). 
Tabela 5.14. Morfologias Observadas em Espuma de Poliuretano e suas Freqüências.

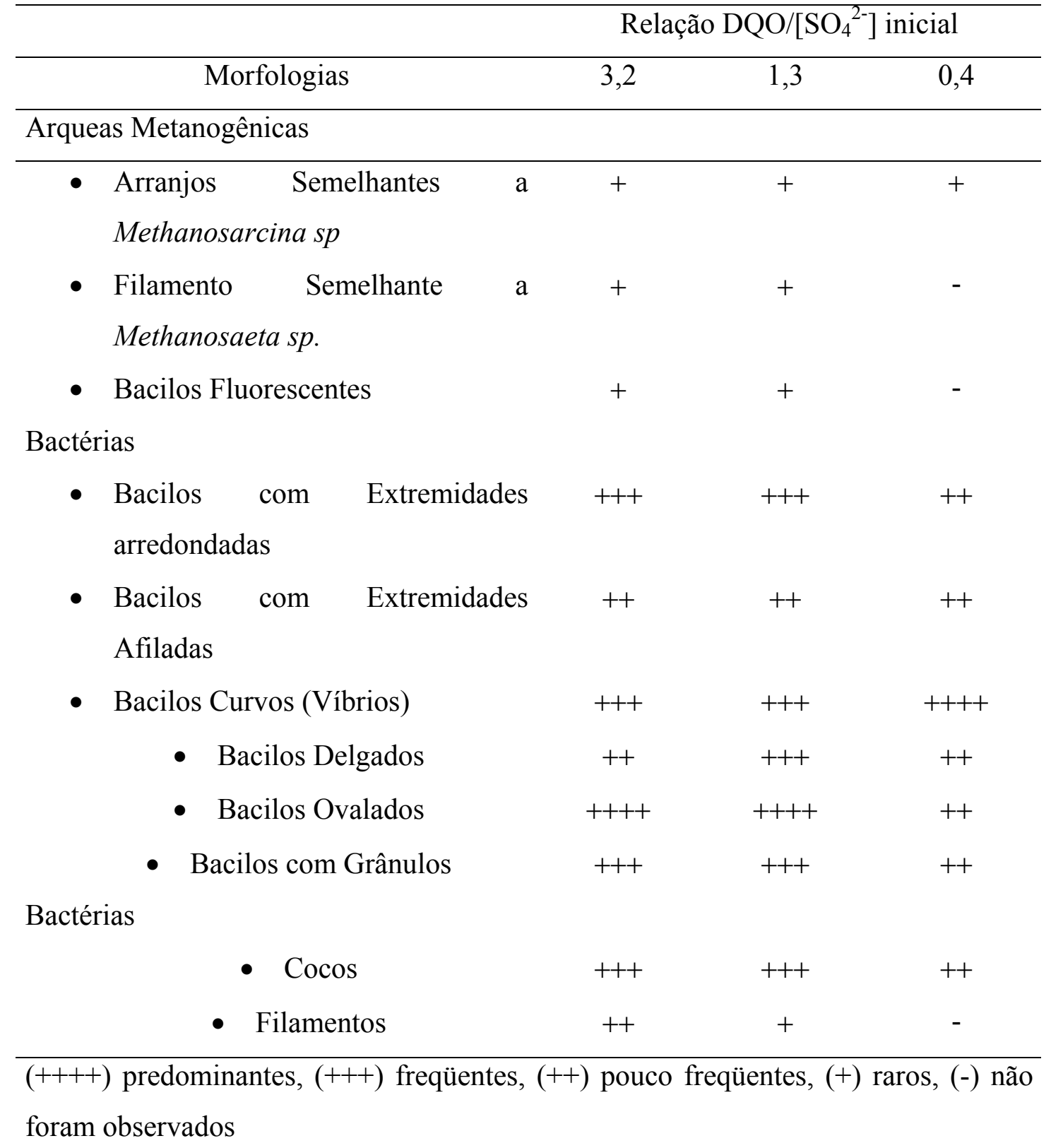




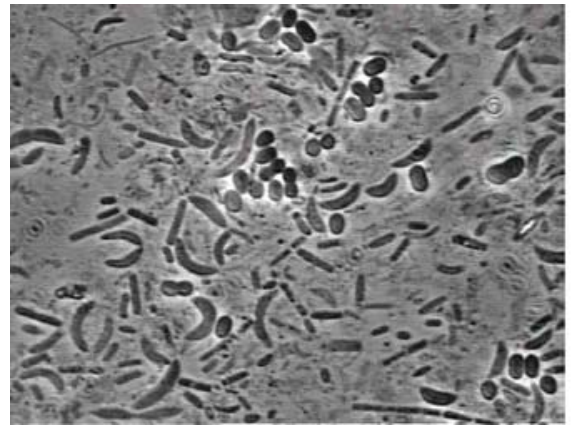

A

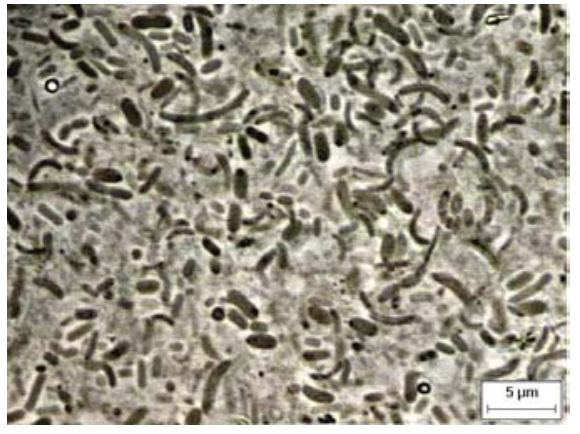

B

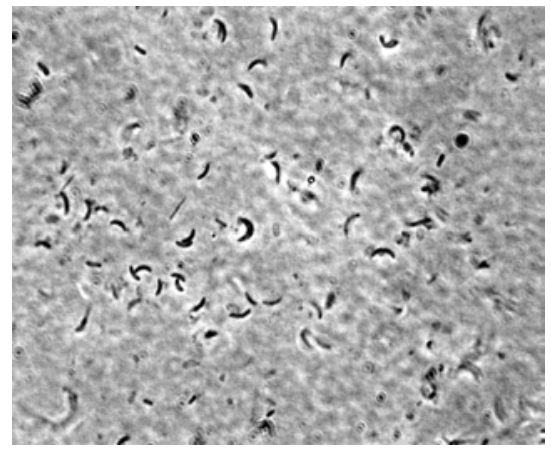

$\mathrm{C}$

Figura 5.49. Morfologias Observadas em PU. (A) Tratamento do meio sintético com relação DQO/[ $\left.\mathrm{SO}_{4}{ }^{2-}\right]$ igual a 3,2: bacilos curvos, bacilos delgados, bacilos ovalados, cocos, filamento semelhante a Methanosaeta sp.. (B) Tratamento do meio sintético com relação DQO/[ $\mathrm{SO}_{4}{ }^{2-i g u a l ~ a ~ 1,3: ~ b a c i l o s ~ c o m ~ e x t r e m i d a d e s ~ a f i l a d a s, ~ b a c i l o s ~}$ curvos, bacilos ovalados, bacilos com grânulos, cocos. (C) Tratamento do meio

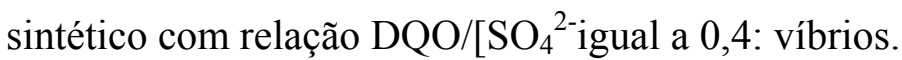

\subsubsection{Quantificação dos Grupos Microbianos por FISH}

Os resultados obtidos por FISH em amostras de PU do ASBBR tratando água residuária sintética com relação $\mathrm{DQO} /\left[\mathrm{SO}_{4}{ }^{2-}\right]$ igual a 3,2 indicaram predominância de bactérias em relação as arqueas. No $30^{\circ}$ ciclo, a porcentagem média de bactérias era $67,4 \%$ e aumentou para 74,5\% no último ciclo de operação, na Condição A. Nesse período, a densidade populacional de BRS aumentou em 18,1\% .

A Figura 5.50 apresenta as porcentagens de células detectadas com as sondas específicas para o domínio bactéria (EUB338), BRS (SRB385), e AM (ARC915) em amostras do MS das partes inferior, meio, e superior do ASBBR com biomassa imobilizada em PU, após o tratamento de água residuária sintética com relação $\mathrm{DQO} /\left[\mathrm{SO}_{4}{ }^{2-}\right]$ igual a 3,2 .. 


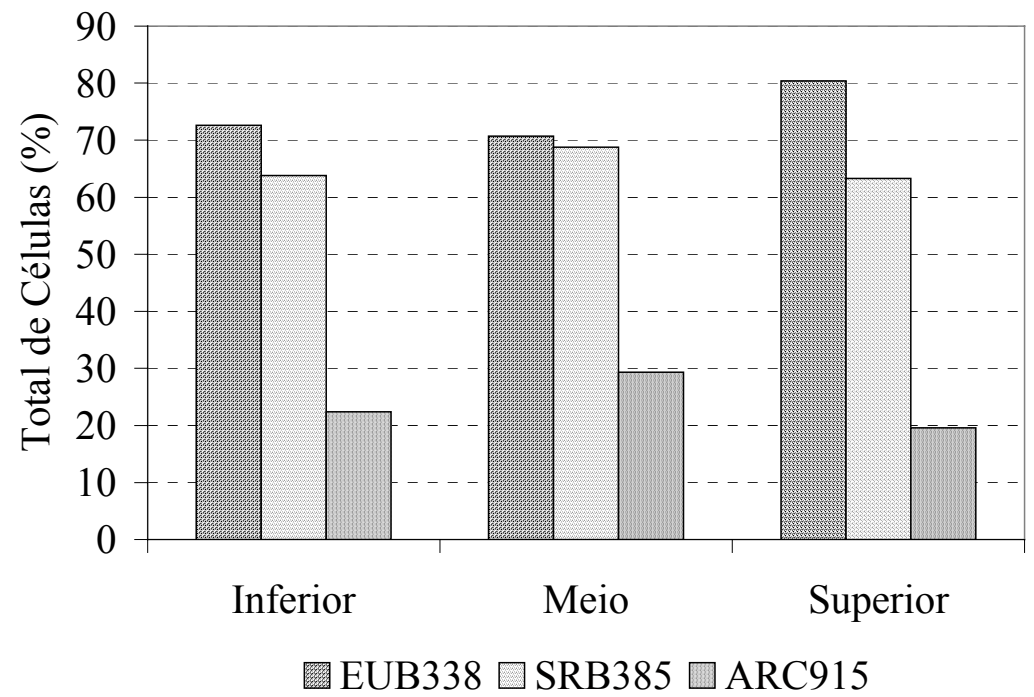

Figura 5.50. Porcentagem de Eubactérias, Bactérias Redutoras de Sulfato, e Arqueas Metanogênicas Detectadas por FISH na Biomassa Imobilizada em Espuma de Poliuretano, Após o Tratamento de Água Residuária Sntética com Relação DQO/[ $\left.\mathrm{SO}_{4}{ }^{2-}\right]$.Igual a 3,2.

A Figura 5.50 mostra que do total das células coradas com DAPI, ou seja, das células hibridadas, o grupo Eubactéria foi predominante nas três regiões do reator analisadas, com média de 74,5\%. As BRS foram predominantes no grupo Eubactéria e corresponderam em média a $65,3 \%$ das células hibridadas. As AM que eram predominantes no inóculo, corresponderam em média a 23,8\% do total de células que foram coradas com DAPI. Esses resultados indicam que a condição de relação $\mathrm{DQO} /\left[\mathrm{SO}_{4}{ }^{2-}\right]$ igual a 3,2 favoreceu o crescimento das BRS em relação aos outros tipos de microrganismos pertencentes ao grupo Eubactéria. A biomassa imobilizada em PU que originalmente continha AM em maior quantidade (Figura 5.48) tornou-se predominantemente sulfetogênica durante o tratamento de água residuária sintética com relação $\mathrm{DQO} /\left[\mathrm{SO}_{4}{ }^{2-}\right]$ igual a 3,2 .

A Figura 5.51 apresenta os resultados obtidos por FISH em PU após tratamento de água residuária sintética com relação $\mathrm{DQO} /\left[\mathrm{SO}_{4}{ }^{2-}\right]$ igual a 0,4 . São indicadas apenas as células detectadas com as sondas EUB338 e SRB385. AM não foram detectadas pelo método de FISH. É possível que a concentração desses microrganismos foi inferior a $10^{4}$ células por mililitro que é o limite de detecção do método (AMANN et al., 1995). 


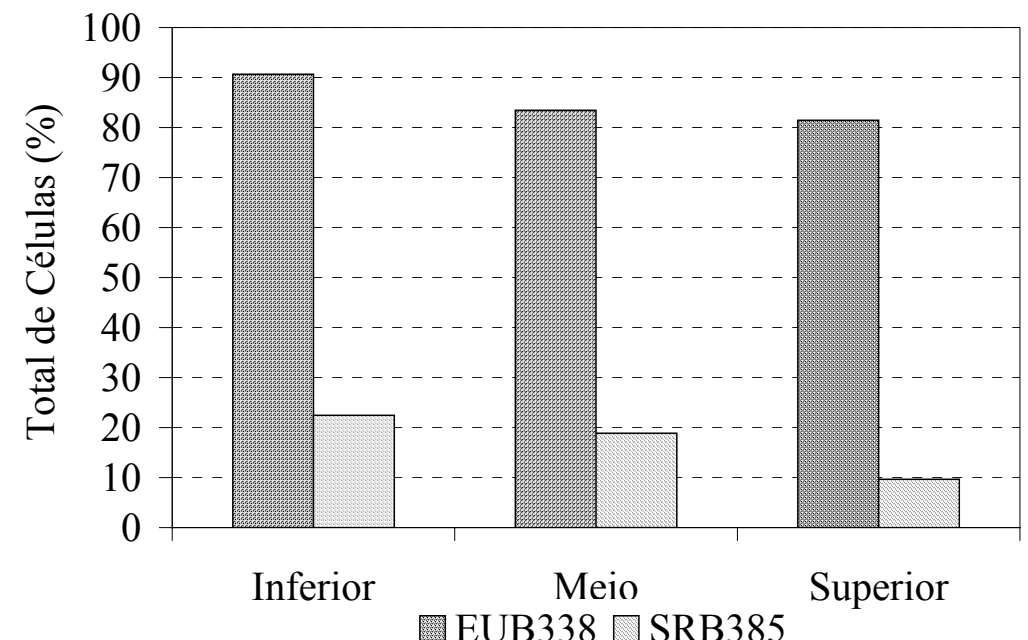

Figura 5.51. Porcentagem de Eubactérias e Bactérias Redutoras de Sulfato Detectadas por FISH na Biomassa Imobilizada em Espuma de Poliuretano, Após o Tratamento de Água Residuária Sntética com Relação DQO/[ $\left.\mathrm{SO}_{4}{ }^{2-}\right]$.Igual a 0,4.

Durante o tratamento de água residuária sintética com relação $\mathrm{DQO} /\left[\mathrm{SO}_{4}{ }^{2-}\right]$ igual a 0,4 observou-se a inibição da metanogênese pela ausência de metano no biogás do ASBBR. A análise por FISH corroborou essas observações. O grupo Eubactéria representou em média $85,2 \%$ das células hibridadas. Todavia, essa condição foi desfavorável para o crescimento das BRS, embora pertencentes ao grupo Eubactéria, esses microrganismos representaram, em média, 17,0\% das células coradas com DAPI. O fator mais provável que restringiu o crescimento das BRS durante o tratamento de água residuária com relação $\mathrm{DQO} /\left[\mathrm{SO}_{4}{ }^{2-}\right]$ igual a 0,4 foi a carência de doador de elétrons e fonte de carbono. De fato, o desempenho na redução de sulfato do ASBBR tratando água residuária sintética com relação $\mathrm{DQO} /\left[\mathrm{SO}_{4}{ }^{2-}\right]$ igual a 0,4 melhorou com a adição de etanol em quantidade estequiométrica em relação a concentração de sulfato.

\subsubsection{Biomassa no Reator com Carvão Vegetal}

As concentrações médias de SSV observadas no efluente do reator RC tratando meio sintético com relações $\mathrm{DQO} /\left[\mathrm{SO}_{4}{ }^{2-}\right]$ iguais a $3,2,1,3$, e 0,4 , foram: $60 \pm 35 \mathrm{mg} . \mathrm{L}^{-1}, 46 \pm 21 \mathrm{mg} . \mathrm{L}^{-1}$, e $71 \pm 25 \mathrm{mg} . \mathrm{L}^{-1}$, respectivamente. As relações em massa entre SSV e MS (gSSV.gMS ${ }^{-1}$ ), a quantidade total de biomassa no reator 
(gSSV) e a concentração de biomassa no reator $\left(\mathrm{gSSV} \cdot \mathrm{L}^{-1}\right)$ são indicadas na Tabela 5.15 .

Tabela 5.15. Quantificação da Biomassa Aderida em Carvão Vegetal no ASBBR

\begin{tabular}{|c|c|c|c|}
\hline Relação DQO/[ $\left[\mathrm{SO}_{4}{ }^{2-}\right]$ & 3,2 & 1,3 & 0,4 \\
\hline gSSV.gMS ${ }^{-1}$ & 0,3 & 0,2 & 0,2 \\
\hline gSSV & 368 & 305 & 240 \\
\hline gSSV.L ${ }^{-1}$ & 75 & 62 & 49 \\
\hline
\end{tabular}

A quantidade específica de biomassa, expressa em SSV, aderida em CV no ASBBR, foi inferior à quantidade específica aderida em PU. Todavia, a quantidade total de biomassa aderida em $\mathrm{CV}$ no reator RC foi em média 12 vezes maior do que em PU no reator RE, e a concentração de SSV no ASBBR contendo CV foi 4,5 vezes maior do que no ASBBR contendo PU. Essas diferenças nas quantidades de biomassa aderida foram decorrentes da diferença de densidade entre os dois tipos de material suporte utilizados.

A Tabela 5.16 apresenta a descrição das morfologias e suas respectivas freqüências, observadas em amostras de $\mathrm{CV}$ no reator $\mathrm{RC}$ operando em condição de estabilidade em redução de sulfato. A Figura 5.52 apresenta algumas das morfologias observadas. 
Tabela 5.16. Morfologias Observadas em Carvão Vegetal no Final do Tratamento de Meio Sintético com Relação DQO/[ $\left.\mathrm{SO}_{4}{ }^{2-}\right]: 3,2,1,3$, e 0,4 .

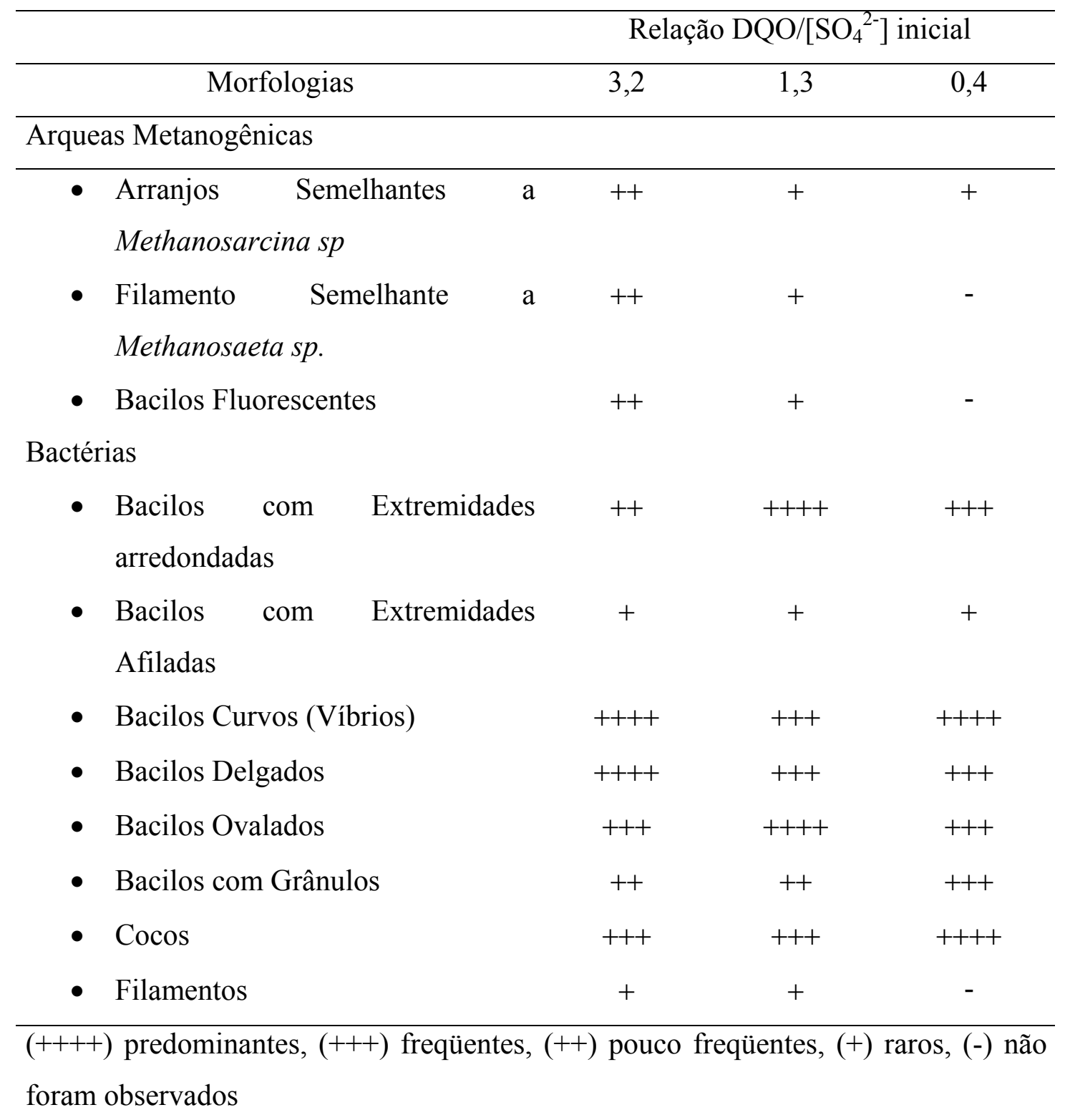




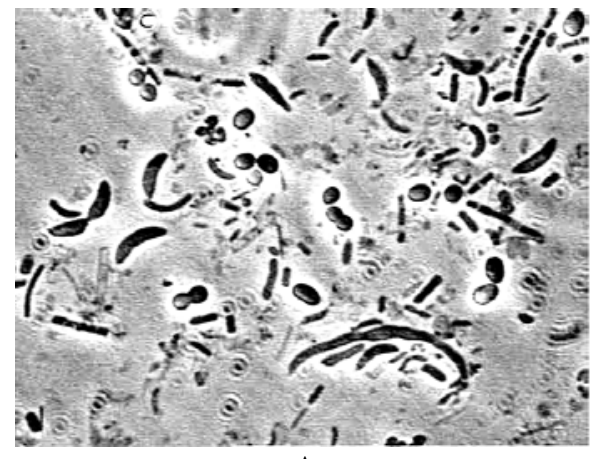

A

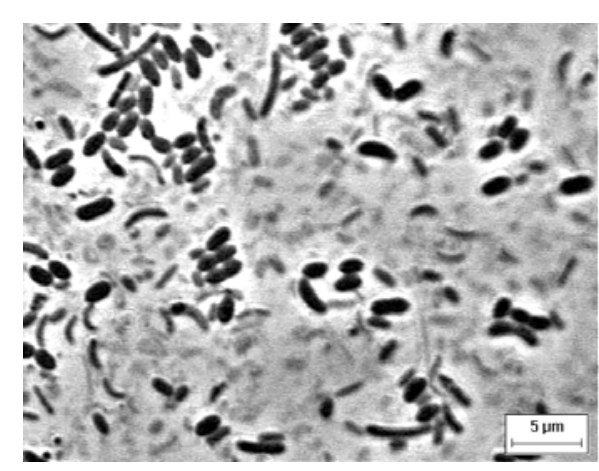

$\mathrm{B}$

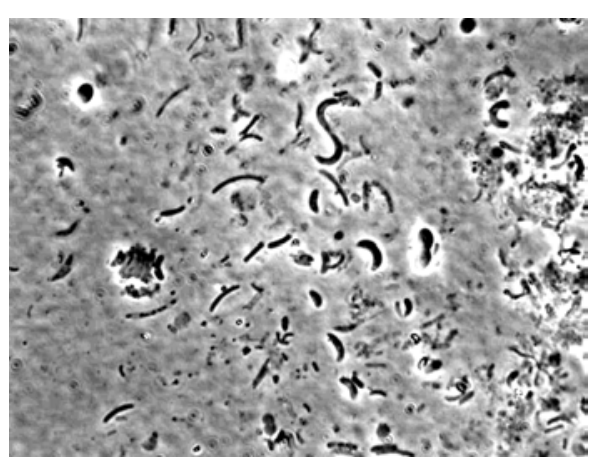

$\mathrm{C}$

Figura 5.52. Morfologias Observadas em Carvão Vegetal. (A) Etapa de operação tratando meio sintético com relação DQO/[ $\left.\mathrm{SO}_{4}{ }^{2-}\right]$ igual a 3,2: bacilos curvos, bacilos delgados, bacilos ovalados, cocos. (B) Etapa de operação tratando meio sintético com relação DQO/[ $\left.\mathrm{SO}_{4}{ }^{2-}\right]$ igual a 1,3: bacilos curvos, bacilos ovalados. (C) Etapa de operação tratando meio sintético com relação $\mathrm{DQO} /\left[\mathrm{SO}_{4}{ }^{2-}\right]$ igual a 0,4 : víbrios e cocos.

\subsubsection{Quantificação dos Grupos Microbianos por FISH}

A Figura 5.53 apresenta as porcentagens de células que foram detectadas com as sondas específicas EUB338, SRB385, e ARC915.

No ASBBR contendo CV como MS tratando água residuária sintética com relação $\mathrm{DQO} /\left[\mathrm{SO}_{4}{ }^{2-}\right]$ igual a 3,2 os microrganismos pertencentes ao grupo Eubactéria predominaram nas três regiões do reator analisadas por FISH (superior, meio, e inferior). Esses microrganismos corresponderam em média a 85,3\% do total de células hibridadas. Dentre esses, as BRS corresponderam em média a 69,1\% das células coradas com DAPI, porcentagem ligeiramente superior à observada em PU $(65,3 \%)$ nas mesmas condições de tratamento. As AM corresponderam em média a $14 \%$ do total de células hibridadas, menos do que foi observado em PU $(23,8 \%)$.

A Figura 5.53 apresenta as porcentagem de células hibridadas que foram detectadas com as sondas EUB338 e SRB385 em amostras de CV após o tratamento de água residuária sintética com relação $\mathrm{DQOO} /\left[\mathrm{SO}_{4}{ }^{2-}\right]$ igual a 0,4 . Não foram detectadas AM, possivelmente esses microrganismos estavam presentes em quantidade inferior ao limite de detecção do método ou foram completamente inibidos pelo processo sulfetogênico. 
Os microrganismos pertencentes ao grupo Eubactéria corresponderam, em média, a 79,9\% do total de células hibridadas. Entretanto, as BRS corresponderam em média a 19,2\% do total de células coradas com DAPI, possivelmente, devido à carência de doador de elétrons e fonte de carbono, pois, o desempenho em redução de sulfato foi melhorado com a adição de etanol.

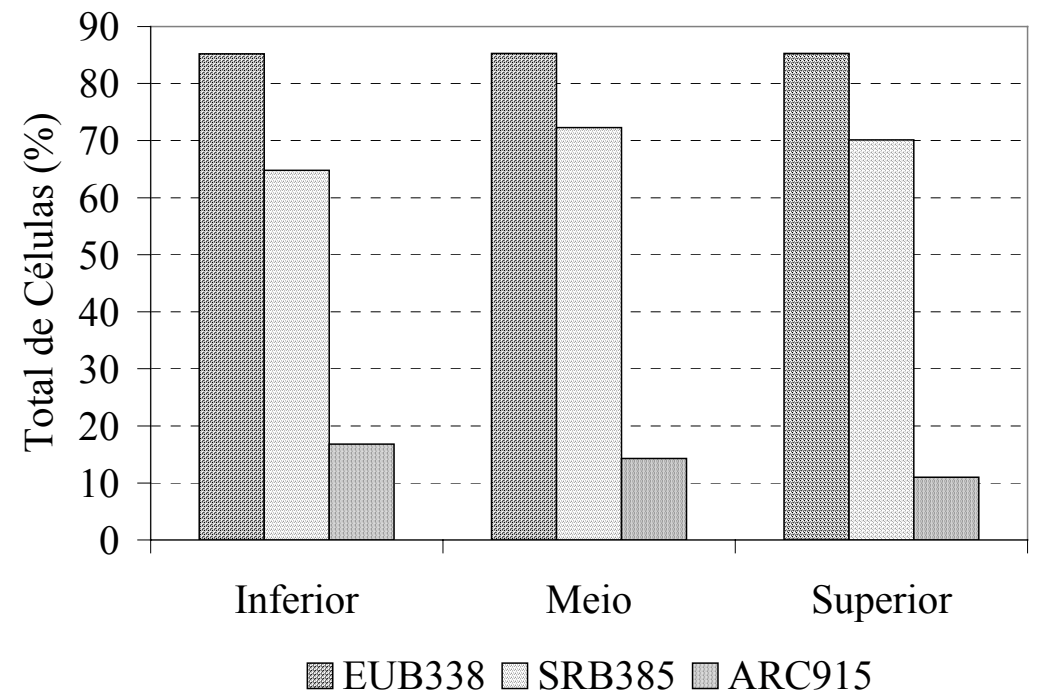

Figura 5.53. Porcentagem de Eubactérias, Bactérias Redutoras de Sulfato, e Arqueas Metanogênicas Detetctadas por FISH na Biomassa Imobilizada em Carvão Vegetal, Após o Tratamento de Água Residuária Sntética com Relação DQO/[SSO $\left.{ }^{2-}\right]$.Igual a 3,2. 


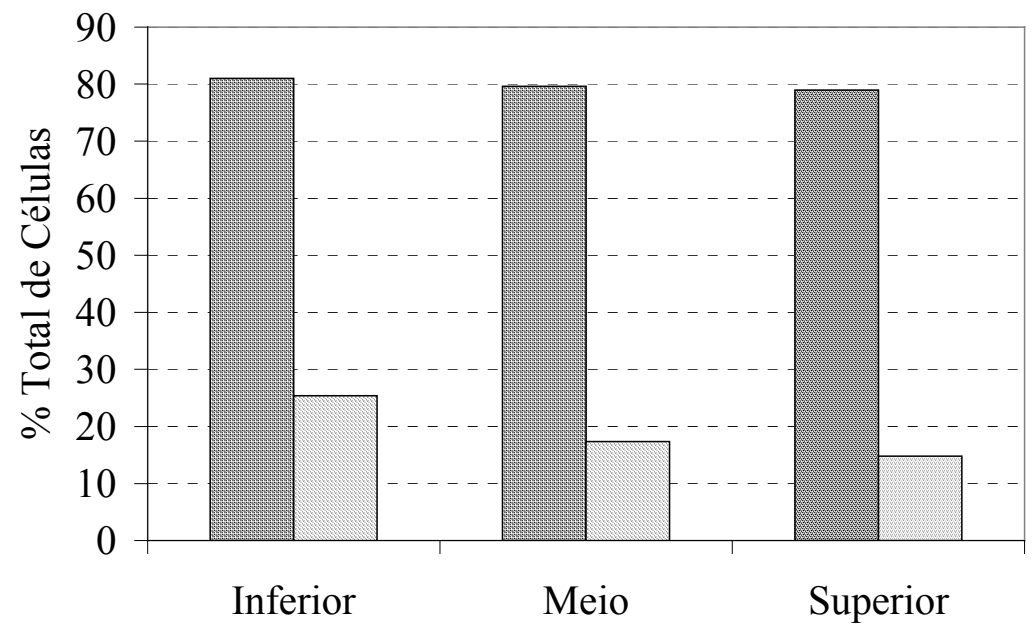

$\square$ EUB338 $\square$ SRB385

Figura 5.54. Porcentagem de Eubactérias e Bactérias Redutoras de Sulfato Detectadas por FISH na Biomassa Imobilizada em Carvão Vegetal, Após o Tratamento de Água Residuária Sintética com Relação DQO/[SO $\left.{ }_{4}{ }^{2-}\right]$.Igual a 0,4.

\subsection{Avaliação do Efeito da Adição de Etanol no Meio Sintético Afluente}

Nessa seção são apresentados os resultados obtidos durante a operação dos $\operatorname{ASBBR}(\mathrm{s})$ alimentados com meio sintético com relação $\mathrm{DQO} /\left[\mathrm{SO}_{4}{ }^{2-}\right]$ igual a 0,4 , e adição de etanol em quantidades igual e o dobro da estequiométrica em relação à concentração de sulfato.

\subsubsection{Adição de Etanol em Quantidade Estequiométrica em Relação à [SO $\left.{ }_{4}{ }^{2-}\right]$}

Inicialmente, os reatores foram alimentados por 7 ciclos consecutivos somente com meio sintético com relação $\mathrm{DQO} /\left[\mathrm{SO}_{4}{ }^{2-}\right]$ igual a 0,4 . Esse procedimento foi necessário porque não houve substituição do MS, mantendo-se a biomassa que estava tratando meio sintético com relação $\mathrm{DQO} /\left[\mathrm{SO}_{4}{ }^{2-}\right]$ igual a 1,3 . Dessa forma, quando a concentração de sulfato remanescente no efluente foi constante, iniciou-se a adição de etanol em quantidade estequiométrica. Os valores das variáveis químicas monitoradas no afluente são apresentados na Tabela 5.17. 
Tabela 5.17. Valores das Variáveis Químicas Monitoradas no Afluente dos Reatores Alimentados com Meio Sintético com Relação DQO/[SO $\left.{ }_{4}{ }^{2-}\right]$ igual a 0,4 e Etanol em Quantidade Estequiométrica.

\begin{tabular}{ccccccc}
\hline \multicolumn{7}{c}{ Afluente } \\
\hline Ciclo & $\mathrm{pH}$ & $\begin{array}{c}\mathrm{AT} \\
\mathrm{mg} . \mathrm{L}^{-1}\end{array}$ & $\begin{array}{c}\mathrm{AB} \\
\mathrm{mg} . \mathrm{L}^{-1}\end{array}$ & $\begin{array}{c}\mathrm{ATV} \\
\mathrm{mg} . \mathrm{L}^{-1}\end{array}$ & $\begin{array}{c}\left.\mathrm{SO}_{4}{ }^{2-}\right] \\
\mathrm{mg} . \mathrm{L}^{-1}\end{array}$ & $\begin{array}{c}\text { DQO } \\
\mathrm{mg} . \mathrm{L}^{-1}\end{array}$ \\
\hline 0 & 6.9 & 269 & 205 & 90 & 2750 & 1000 \\
7 & 7.7 & 288 & 250 & 54 & 2640 & 2216 \\
11 & 7.2 & 288 & n.a. & n.a. & 2223 & 2333 \\
14 & 7.5 & n.a. & n.a. & n.a. & 2537 & 2333 \\
19 & 7.5 & 288 & n.a. & n.a. & 2870 & 2857 \\
\hline
\end{tabular}

n.a. - Não Analisado

Quando se iniciou a adição de etanol em quantidade estequiométrica , a relação $\mathrm{DQO} /\left[\mathrm{SO}_{4}{ }^{2-}\right]$ média aumentou para 0,9. A seguir são apresentados os resultados obtidos nos efluentes dos reatores RE e RC.

\subsubsection{Reator com Espuma de Poliuretano (RE)}

Inicialmente, o reator $\mathrm{RE}$ foi alimentado com meio sintético com relação $\mathrm{DQO} /\left[\mathrm{SO}_{4}{ }^{2-}\right]$ igual a0,4 até demonstrar estabilidade em redução de sulfato. Nessa condição iniciou-se a adição de etanol em quantidade estequiométrica. Dessa forma, foram realizados 25 ciclos para a avaliação do efeito do etanol no processo sulfetogênico nesse reator. Os respectivos valores das variáveis monitoradas no efluente são apresentados na Tabela 5.18. 
Tabela 5.18. Valores das Variáveis Monitoradas no Efluente do Reator com Espuma de Poliuretano Alimentado com Meio Sintético e Etanol Sendo Adicionado em

Quantidade Estequiométrica Relacionada a Concentração de Sulfato.

\begin{tabular}{ccccccc}
\hline Ciclo & $\mathrm{pH}$ & $\begin{array}{c}\mathrm{AT} \\
\mathrm{mg} . \mathrm{L}^{-1}\end{array}$ & $\begin{array}{c}\mathrm{AB} \\
\mathrm{mg} . \mathrm{L}^{-1}\end{array}$ & $\begin{array}{c}\mathrm{ATV} . \\
\mathrm{mg} . \mathrm{L}^{-1}\end{array}$ & $\begin{array}{c}{\left[\mathrm{SO}_{4}{ }^{2-}\right]} \\
\mathrm{mg} . \mathrm{L}^{-1}\end{array}$ & $\begin{array}{c}\mathrm{DQO} \\
\mathrm{mg} . \mathrm{L}^{-1}\end{array}$ \\
\hline 0 & 6,6 & 1236 & 1204 & 44 & 2000 & 392 \\
7 & 7,7 & 1432 & 804 & 884 & 678 & 788 \\
11 & 7,2 & 1460 & 779 & 959 & 423 & 1177 \\
14 & 7,4 & n.a. & n.a. & n.a. & 437 & 1433 \\
19 & 7,7 & 1742 & 963 & 1097 & 749 & 1561 \\
25 & 7,3 & 1634 & 1046 & 828 & 485 & 979
\end{tabular}

AT: Alcalinidade Total; AB: Alcalinidade a Bicarbonato; AVT: Ácidos Voláteis

Totais; n.a.: Não Analisado.

Na Tabela 5.18 pode ser observado que a $\left[\mathrm{SO}_{4}{ }^{2-}\right]$ remanescente no efluente do reator RE diminuiu a partir do $7^{\underline{0}}$ ciclo operacional, mantendo-se, a partir desse ciclo, valor médio de 554 $\pm 149 \mathrm{mg} . \mathrm{L}^{-1}$. Em outras palavras, observou-se aumento da eficiência em redução de sulfato, de $27 \%$ para $80 \%$ após 7 ciclos adicionando-se etanol no meio sintético, em quantidade estequiométrica em relação à $\left[\mathrm{SO}_{4}{ }^{2-}\right]$. Todavia, a DQO remanescente aumentou de $392 \mathrm{mg} \cdot \mathrm{L}^{-1}$ para $1188 \pm 317 \mathrm{mg} . \mathrm{L}^{-1}$. Esse aumento na DQO indica que os substratos orgânicos, principalmente etanol, foram oxidados parcialmente, fato comprovado pelo aumento na concentração de ATV remanescente, de $44 \mathrm{mg} . \mathrm{L}^{-1}$ para $942 \pm 116 \mathrm{mg} . \mathrm{L}^{-1}$.

Observou-se aumento na AT do efluente, de $1236 \mathrm{mg} . \mathrm{L}^{-1}$ para $1567 \pm 147$ mg. $\mathrm{L}^{-1}$. Entretanto, a AB diminuiu de $1204 \mathrm{mg} . \mathrm{L}^{-1}$ para $898 \pm 128 \mathrm{mg} . \mathrm{L}^{-1}$. O aumento na AT foi devido ao aumento dos ATV e da concentração de sulfeto total. Esse fato também foi observado em RAHLF tratando meio sintético com concentrações crescentes de sulfato (CADAVID et al., 1999). AB foi consumida na neutralização de parte dos ATV. Nessa etapa experimental não foi medida a [ST] no efluente. O reator RE tornou-se completamente sulfetogênico, pois, não foi detectado metano no biogás. 


\subsubsection{Reator com Carvão Vegetal}

Foram realizados 25 ciclos no reator RC adicionando-se etanol ao meio sintético em quantidade estequiométrica em relação à $\left[\mathrm{SO}_{4}{ }^{2-}\right]$. Os valores das variáveis monitoradas no efluente do reator RC são apresentados na Tabela 5.19.

Tabela 5.19. Valores das Variáveis Monitoradas no Reator com Carvão Vegetal (RC) Alimentado com Meio Sintético e Etanol Sendo Adicionado em Quantidade Estequiométrica Relacionada a Concentração de Sulfato.

\begin{tabular}{ccccccc}
\hline Ciclo & $\mathrm{pH}$ & $\begin{array}{c}\mathrm{AT} \\
\mathrm{mg} . \mathrm{L}^{-1}\end{array}$ & $\begin{array}{c}\mathrm{AB} \\
\mathrm{mg} . \mathrm{L}^{-1}\end{array}$ & $\begin{array}{c}\mathrm{ATV} \\
\mathrm{mg} . \mathrm{L}^{-1}\end{array}$ & $\begin{array}{c}{\left[\mathrm{SO}_{4}{ }^{2-}\right]} \\
\mathrm{mg} . \mathrm{L}^{-1}\end{array}$ & $\begin{array}{c}\mathrm{DQO} \\
\mathrm{mg} . \mathrm{L}^{-1}\end{array}$ \\
\hline 0 & 6,8 & 1401 & 1373 & 40 & 1800 & 436 \\
7 & 7,9 & 1493 & 982 & 720 & 557 & 788 \\
11 & 7,2 & 1649 & 972 & 953 & 451 & 944 \\
14 & n.a. & n.a. & n.a. & n.a. & 458 & 1270 \\
19 & 7,6 & 1920 & 1206 & 1005 & 632 & 1561 \\
25 & 7,3 & 1719 & 1025 & 977 & 412 & 1305
\end{tabular}

AT: Alcalinidade Total; AB: Alcalinidade a Bicarbonato; AVT: Ácidos Voláteis Totais; n.a.: Não Analisado.

Observou-se que a $\left[\mathrm{SO}_{4}{ }^{2-}\right]$ remanescente diminuiu de $1800 \mathrm{mg} . \mathrm{L}^{-1}$ para $500 \pm 90 \mathrm{mg} . \mathrm{L}^{-1}$, correspondendo ao aumento na eficiência em redução de sulfato de $35 \%$ para $82 \%$. A DQO remanescente aumentou de $436 \mathrm{mg} . \mathrm{L}^{-1}$ para $1174 \pm 307$ mg. $\mathrm{L}^{-1}$. Esse aumento na DQO foi devido ao aumento na concentração de ATV de 40 mg. $\mathrm{L}^{-1}$ para $914 \pm 131 \mathrm{mg} . \mathrm{L}^{-1}$. AT aumentou de $1400 \mathrm{mg} . \mathrm{L}^{-1}$ para $1695 \pm 177 \mathrm{mg} . \mathrm{L}^{-1}$, em função da geração de alcalinidade devida ao sulfeto e ao aumento dos AVT. AB diminuiu de $1376 \mathrm{mg} . \mathrm{L}^{-1}$ para $1046 \pm 109 \mathrm{mg} . \mathrm{L}^{-1}$ devido ao consumo na neutralização de ATV.

A adição de etanol em quantidade estequiométrica em relação à concentração de sulfato resultou em melhoria de desempenho na redução de sulfato com aumento na DQO remanescente. O reator RC apresentou equilíbrio satisfatório, mantendo a $\mathrm{AB}$ em níveis adequados para suportar o aumento de ATV. Desse modo, é recomendável a adição de etanol nessa quantidade com a finalidade de aumentar a 
eficiência de reatores sulfetogênicos tratando águas residuárias com relações $\mathrm{DQO} /\left[\mathrm{SO}_{4}{ }^{2-}\right]$ menores que 1,0 . Todavia, o efluente desses reatores deverá ser destinado a processo subseqüente para remoção da DQO.

\subsubsection{Adição de Etanol em Quantidade Correspondendo ao Dobro da}

\section{Estequiométrica}

Nessa etapa do experimento dobrou-se a dosagem de etanol em relação à quantidade estequiométrica a fim de aumentar as eficiências médias em redução de sulfato observadas nos reatores RE e RC após adição de etanol em quantidade estequiométrica. Os valores das variáveis químicas monitoradas no afluente são apresentados na Tabela 5.20.

Quando se adicionou etanol em quantidade correspondente ao dobro da estequiométrica , a relação $\mathrm{DQO} /\left[\mathrm{SO}_{4}{ }^{2-}\right]$ média aumentou para 1,3 . 
Tabela 5.20. Valores das Variáveis Químicas Monitoradas no Afluente dos Reatores Alimentados com Meio Sintético com Relação DQO/[ $\left.\mathrm{SO}_{4}{ }^{2-}\right]$ igual a 0,4 e Etanol em Quantidade Correspondente ao Dobro da Estequiométrica.

\begin{tabular}{ccccccc}
\hline \multicolumn{7}{c}{ Afluente } \\
\hline Ciclo & pH & AT & AB & AVT & {$\left[\mathrm{SO}_{4}{ }^{2-}\right]$} & DQO \\
& & mg.L ${ }^{-1}$ & mg.L ${ }^{-1}$ & mg.L ${ }^{-1}$ & mg.L. ${ }^{-1}$ & mg.L ${ }^{-1}$ \\
0 & 7,7 & 198 & 169 & 41 & 1700 & 1518 \\
3 & n.a. & n.a. & n.a. & n.a. & n.a. & n.a. \\
7 & n.a. & n.a. & n.a. & n.a. & n.a. & n.a. \\
10 & n.a. & n.a. & n.a. & n.a. & 1950 & 2156 \\
14 & 7,9 & 196 & 172 & 44 & 1650 & 3090
\end{tabular}

AT: Alcalinidade Total; AB: Alcalinidade a Bicarbonato; AVT: Ácidos Voláteis Totais; n.a.: Não Analisado.

\subsubsection{Reator com Espuma de Poliuretano (RE)}

Foram realizados 14 ciclos nessa etapa do experimento. Os valores das variáveis monitoradas no efluente são apresentados na Tabela 5.21.

Tabela 5.21. Valores das Variáveis Monitoradas no Efluente do Reator com Espuma de Poliuretano Alimentado com Meio Sintético e Etanol Sendo Adicionado em Quantidade Correspondente ao Dobro da Estequiométrica em relação a [ $\left.\mathrm{SO}_{4}{ }^{2-}\right]$.

\begin{tabular}{|c|c|c|c|c|c|c|c|}
\hline Ciclo & $\mathrm{pH}$ & $\begin{array}{c}\text { AT } \\
\left(\mathrm{mg} \cdot \mathrm{L}^{-1}\right)\end{array}$ & $\begin{array}{c}\mathrm{AB} \\
\left(\mathrm{mg} \cdot \mathrm{L}^{-1}\right)\end{array}$ & $\begin{array}{c}\text { ATV } \\
\left(\mathrm{mg} . \mathrm{L}^{-1}\right)\end{array}$ & $\begin{array}{c}{\left[\mathrm{SO}_{4}{ }^{2-}\right]} \\
\left(\mathrm{mg} . \mathrm{L}^{-1}\right)\end{array}$ & $\begin{array}{c}\mathrm{ST} \\
\left(\mathrm{mg} . \mathrm{L}^{-1}\right)\end{array}$ & $\begin{array}{c}\text { DQO } \\
\left(\mathrm{mg} . \mathrm{L}^{-1}\right)\end{array}$ \\
\hline 0 & 6,8 & 1457 & 985 & 665 & 320 & 89 & 935 \\
\hline 3 & n.a. & n.a. & n.a. & n.a. & 270 & n.a. & n.a. \\
\hline 7 & n.a. & n.a. & n.a. & n.a. & 380 & 82 & 1643 \\
\hline 10 & n.a. & n.a. & n.a. & n.a. & 190 & n.a. & 2365 \\
\hline 14 & 6,7 & 1564 & 34 & 2154 & 120 & 74 & 2680 \\
\hline
\end{tabular}

AT: Alcalinidade Total - AB: Alcalinidade a Bicarbonato; ATV: Ácidos Totais Voláteis; n.a.: Não Analisado.

$\mathrm{Na}$ Tabela 5.21 pode ser observado que a $\left[\mathrm{SO}_{4}{ }^{2-}\right]$ remanescente no efluente do reator, observada após 14 ciclos, diminuiu $63 \%$ em relação ao início da operação 
com a adição de etanol em quantidade correspondente ao dobro da estequiométrica. Por outro lado, a DQO foi quase triplicada, devido ao aumento na concentração de ATV (665-2154 mg. $\left.\mathrm{L}^{-1}\right)$. AB foi consumida para neutralizar os ATV produzidos com tendência de queda no $\mathrm{pH}$.

$\mathrm{O}$ aumento na dosagem de etanol resultou em aumento na eficiência em redução de sulfato para 93\%. Porém, houve aumento expressivo na concentração de ATV e, conseqüentemente, da DQO. AB foi totalmente consumida, fato que resultou em desequilíbrio e instabilidade do reator.

\subsubsection{Reator com Carvão Vegetal (RC)}

Foram realizados 14 ciclos nessa etapa do experimento. Os valores das variáveis monitoradas no efluente são apresentados na Tabela 5.22.

Tabela 5.22. Valores das Variáveis Monitoradas no Efluente do Reator com Carvão Vegetal Alimentado com Meio Sintético e Etanol Sendo Adicionado em Quantidade Correspondente ao Dobro da Estequiométrica em relação a [ $\left.\mathrm{SO}_{4}{ }^{2-}\right]$.

\begin{tabular}{cccccccc}
\hline Ciclo & $\mathrm{pH}$ & $\begin{array}{c}\mathrm{AT} \\
\left(\mathrm{mg} . \mathrm{L}^{-1}\right)\end{array}$ & $\begin{array}{c}\mathrm{AB} \\
\left(\mathrm{mg} . \mathrm{L}^{-1}\right)\end{array}$ & $\begin{array}{c}\mathrm{ATV} \\
\left(\mathrm{mg} . \mathrm{L}^{-1}\right)\end{array}$ & $\begin{array}{c}{\left[\mathrm{SO}_{4}{ }^{2-}\right]} \\
\left(\mathrm{mg} . \mathrm{L}^{-1}\right)\end{array}$ & $\begin{array}{c}\mathrm{ST} \\
\left(\mathrm{mg} . \mathrm{L}^{-1}\right)\end{array}$ & $\begin{array}{c}\text { DQO } \\
\left(\mathrm{mg} . \mathrm{L}^{-1}\right)\end{array}$ \\
\hline 0 & 6,6 & 1524 & 1036 & 687 & 200 & 179 & 1002 \\
3 & n.a. & n.a. & n.a. & n.a. & 260 & n.a. & n.a. \\
7 & n.a. & 694 & 722 & 1995 & 420 & 82 & 2062 \\
10 & n.a. & n.a. & n.a. & n.a. & 260 & n.a. & 2272 \\
14 & 6,4 & 196 & 0 & 2267 & 70 & 94 & 2889 \\
\hline
\end{tabular}

AT: Alcalinidade Total - AB: Alcalinidade a Bicarbonato; ATV: Ácidos Totais Voláteis; n.a.: Não Analisado.

$\mathrm{Na}$ Tabela 5.22 pode ser observado que a $\left[\mathrm{SO}_{4}{ }^{2-}\right]$ remanescente no efluente do reator RC, após 14 ciclos, diminuiu 65\% em relação ao início da operação com a adição de etanol em quantidade correspondente ao dobro da estequiométrica. Por outro lado, a DQO foi quase triplicada, devido ao aumento na concentração de ATV , aumentou de $687 \mathrm{mg} . \mathrm{L}^{-1}$ para $2267 \mathrm{mg} . \mathrm{L}^{-1}$. AB foi consumida para neutralizar os ATV produzidos com tendência de queda no $\mathrm{pH}$. 
O aumento na dosagem de etanol resultou em aumento na eficiência em redução de sulfato para $96 \%$. Porém, houve aumento expressivo na concentração de ATV e, conseqüentemente, da DQO. AB foi totalmente consumida, fato que resultou em desequilíbrio e instabilidade do reator. Portanto a adição de etanol em quantidade superior a estequiométrica deve ser acompanhada da adição de uma fonte externa de alcalinidade (por exemplo, bicarbonato de sódio) para manter a estabilidade do reator, caso contrário, essa prática deve ser evitada.

\subsection{Modelação Cinética - Alimentação dos Reatores com Meio Sintético com Relações DQO/[SOO $\left.{ }_{4}{ }^{2-}\right]$ Igual a 3,2, 1,3, e 0,4 .}

Nessa seção são apresentados os resultados obtidos nos perfis temporais das variáveis: $\mathrm{DQO},[\mathrm{Hac}]$ expressa em $\mathrm{DQO}$ e $\left[\mathrm{SO}_{4}{ }^{2-}\right]$, nos efluentes dos reatores alimentados com meio sintético com relações DQO/[ $\left.\mathrm{SO}_{4}{ }^{2-}\right]$ iguais a 3,2, 1,3, 0,4. Os resultados obtidos nesses perfis foram utilizados para ajuste de modelos cinéticos propostos para representar as rotas metabólicas desenvolvidas por BRS, BA e AM nessas condições de estudo.

Nesse trabalho, não foram medidos todos os intermediários de fermentação e nem a concentração de hidrogênio. Dessa forma, optou-se por um modelo simplificado partindo-se da matéria orgânica (MO) representada por polímeros, monômeros e intermediários de fermentação. Hac foi considerado como intermediário no modelo para distinção das rotas de degradação de substratos orgânicos: acetogênica e não-acetogência. O modelo simplificado é apresentado na Figura 5.55.

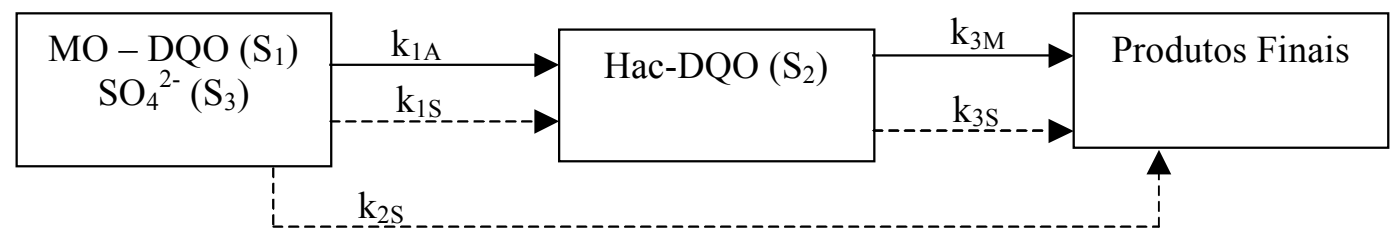

Figura 5.55. Diagrama do Modelo Cinético Simplificado para Descrição das Rotas de

Utilização de Substratos Orgânicos em Reatores Anaeróbios com Presença de Sulfato. 
$\mathrm{Na}$ Figura 5.55, $\mathbf{S}_{1}$ é a matéria orgânica quantificada na forma de DQO, exceto ácido acético, Hac-DQO ou $\mathbf{S}_{\mathbf{2}}$ representa a concentração de ácido acético expressa em DQO, $\mathbf{S}_{\mathbf{3}}$ representa a concentração de sulfato, $\mathbf{k}_{\mathbf{1 A}}$ é a constante cinética da reação de primeira ordem que representa o consumo de $\mathrm{S} 1$ por $\mathrm{BA}, \mathbf{k}_{1 \mathrm{~S}}$ é a constante cinética da reação de segunda ordem que representa a oxidação incompleta de S1 por BRS, $\mathbf{k}_{2 \mathrm{~S}}$ é a constante cinética da reação de segunda ordem que representa a oxidação completa de S1 pela via não-acetogênica, por BRS, $\mathbf{k}_{3 \mathbf{M}}$ é a constante cinética da reação de primeira ordem que representa o consumo de ácido acético (S2) por AM, e $\mathbf{k}_{3 \mathrm{~S}}$ é a constante cinética de segunda ordem que representa o consumo de Hac (S2) por BRS. O modelo cinético gerou o sistema de equações diferenciais composto pelas equações 5.10 a 5.12 .

$$
\begin{aligned}
& \frac{d C S_{1}}{d t}=-k_{1 A} C S_{1}-k_{2 M} C S_{1}-k_{1 S} C S_{1} C S_{3}-k_{2 S} C S_{1} C S_{3} \\
& \frac{d C S_{2}}{d t}=k_{1 A} C S_{1}+k_{1 S} C S_{1} C S_{3}-k_{3 M} C S_{2}-k_{3 S} C S_{1} C S_{3} \\
& \frac{d C S_{3}}{d t}=-k_{1 S} C S_{1} C S_{3}-k_{2 S} C S_{1} C S_{3}-k_{3 S} C S_{1} C S_{3}
\end{aligned}
$$

No sistema de equações diferenciais, $\mathrm{CS}_{1}, \mathrm{CS}_{2}$, e $\mathrm{CS}_{3}$ representam as concentrações $\left(m g . L^{-1}\right)$ de $S_{1}, S_{2}$ e $S_{3}$, respectivamente. Esse sistema de equações diferenciais foi resolvido numericamente pelo método de Runge-Kutta de $4^{\mathrm{a}}$ ordem, utilizando o programa desenvolvido no Microsoft Excel ${ }^{\circledR}$ por DEBASTIANI (2002). Os valores das constantes cinéticas $\left(\mathrm{k}_{1 \mathrm{~A}}, \mathrm{k}_{1 \mathrm{~S}}, \mathrm{k}_{2 \mathrm{~S}}, \mathrm{k}_{3 \mathrm{M}}\right.$ e $\left.\mathrm{k}_{3 \mathrm{~S}}\right)$ foram arbitrados inicialmente (chute inicial) e, utilizando a ferramenta "Solver" do Microsoft Excel ${ }^{\circledR}$, foram minimizados os desvios entre os valores teóricos e os observados experimentalmente. Dessa forma, foram obtidos os valores das constantes cinéticas otimizados. Com a obtenção das constantes cinéticas obteve-se o perfil das velocidades aparentes $\left(\mathrm{r}_{\text {ap }}\right)$ de utilização de substratos orgânicos por BA, BRS e AM. A seguir são apresentados os resultados da modelação cinética nos reatores RE e RC. 


\subsubsection{Reator com Espuma de Poliuretano (RE) Tratando Meio Sintético com} $\left.\underline{\text { Relação DQO/[SO}}{ }_{4}{ }^{2-}\right]$ Igual a 3,2

A Tabela 5.23 apresenta os valores obtidos em perfis temporais das variáveis: $\mathrm{CS} 1, \mathrm{CS} 2$ e CS3, no reator $\mathrm{RE}$ tratando meio sintético com relação $\mathrm{DQO} /\left[\mathrm{SO}_{4}{ }^{2-}\right]$ igual a 3,2 em condição de estabilidade em redução de sulfato. Os valores de [Hac] foram convertidos em DQO multiplicando-os pelo fator 1,07 conforme a reação representada pela equação 5.13. A Figura 5.56 apresenta o ajuste do modelo cinético aos valores medidos nos perfis temporais.

$\mathrm{CH}_{3} \mathrm{COOH}+2 \mathrm{O}_{2} \rightarrow 2 \mathrm{CO}_{2}+2 \mathrm{H}_{2} \mathrm{O}$

Tabela 5.23. Perfil Temporal das Variáveis: CS1, CS2 e CS3 no reator com Espuma de Poliuretano Tratando Meio Sintético com Relação DQO/[ $\left.\mathrm{SO}_{4}{ }^{2-}\right]$ igual a 3,2.

\begin{tabular}{cccc}
\hline $\begin{array}{c}\text { Tempo } \\
\mathrm{h}\end{array}$ & $\begin{array}{c}\mathrm{CS} 1 \\
\mathrm{mg} . \mathrm{L}^{-1}\end{array}$ & $\begin{array}{c}\mathrm{CS} 2 \\
\mathrm{mg} . \mathrm{L}^{-1}\end{array}$ & $\begin{array}{c}\mathrm{CS} 3 \\
\mathrm{mg} . \mathrm{L}^{-1}\end{array}$ \\
\hline 0 & 521 & 70 & 211 \\
2 & 346 & 134 & 171 \\
4 & 226 & 73 & 60 \\
6 & n.a. & n.a. & 53 \\
8 & 118 & 101 & 38 \\
10 & 108 & 101 & 23 \\
12 & 112 & 83 & 23 \\
\hline
\end{tabular}




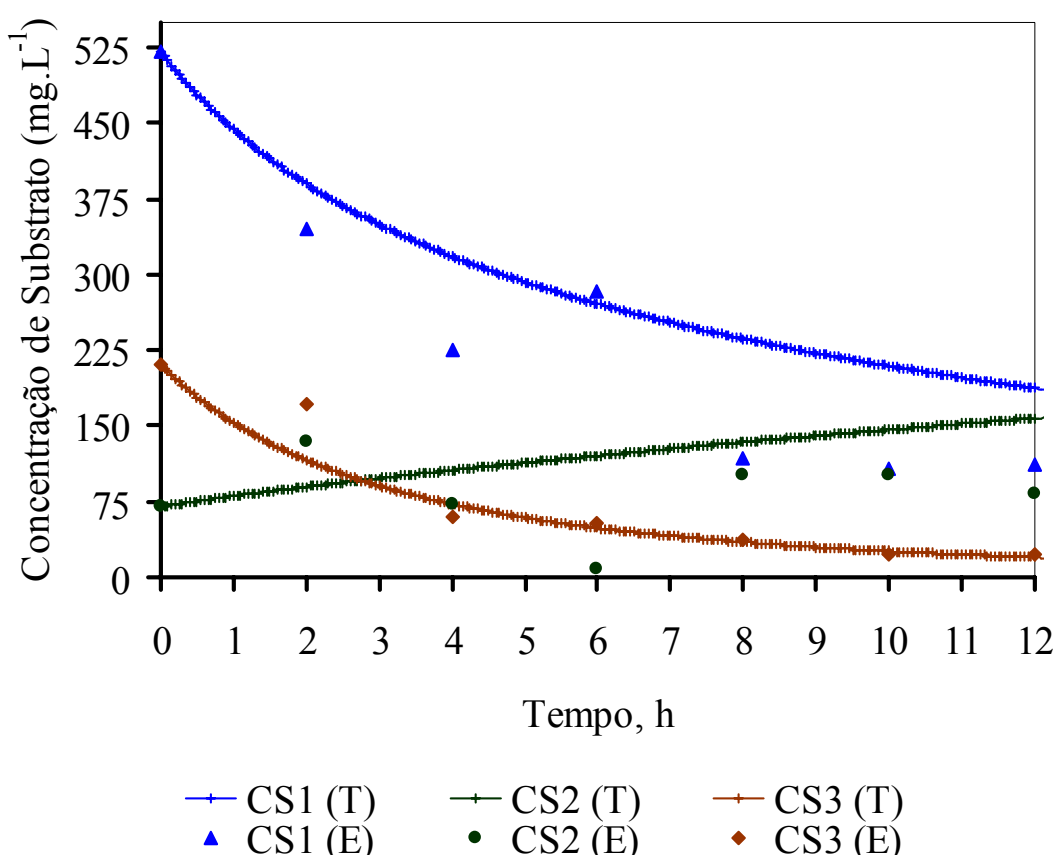

Figura 5.56. Ajuste do Modelo Cinético aos Valores Medidos nos Perfis Temporais das Variáveis: CS1, CS2 e CS3 no Reator com Espuma de Poliuretano Tratando Meio Sintético com Relação DQO/[ $\left.\mathrm{SO}_{4}{ }^{2-}\right]$ igual a 3,2. (T) indica os valores calculados pelo modelo e (E) indica os valores empíricos.

Observa-se na Figura 5.56 que o modelo cinético ajustou-se bem aos dados experimentais. Os testes de hipóteses aplicados, com significância de 5\%, indicaram que o modelo cinético proposto foi adequado para representar as principais rotas de utilização de matéria orgânica no reator RE tratando meio sintético com relação $\mathrm{DQO} /\left[\mathrm{SO}_{4}{ }^{2-}\right]$ igual a 3,2. A Tabela 5.24 apresenta os valores das constantes cinéticas obtidas após o ajuste do modelo aos valores empíricos. 
Tabela 5.24. Valores das Constantes Cinéticas Calculados pelo Ajuste do Modelo Cinético aos Valores Medidos nos Perfis Temporais

\begin{tabular}{ccc}
\hline Constantes & Valores $\left(\times 10^{-4}\right)$ & Unidade \\
\hline $\mathrm{k}_{1 \mathrm{~A}}$ & 403 & $\mathrm{~h}^{-1}$ \\
$\mathrm{k}_{3 \mathrm{M}}$ & 10 & $\mathrm{~h}^{-1}$ \\
$\mathrm{k}_{1 \mathrm{~S}}$ & 0 & $\mathrm{~L} \cdot \mathrm{mg}^{-1} \cdot \mathrm{h}^{-1}$ \\
$\mathrm{k}_{2 \mathrm{~S}}$ & 7 & $\mathrm{~L} \cdot \mathrm{mg}^{-1} \cdot \mathrm{h}^{-1}$ \\
$\mathrm{k}_{3 \mathrm{~S}}$ & 0 & $\mathrm{~L} \cdot \mathrm{mg}^{-1} \cdot \mathrm{h}^{-1}$ \\
\hline
\end{tabular}

Os valores das constantes cinéticas indicam que: (i) S1 foi oxidado parcialmente por BA e BRS. Uma parte de $\mathrm{S} 1$ foi oxidada completamente a $\mathrm{CO}_{2}$ por espécies de BRS oxidadoras completas - (ii) BRS não competiram com AM acetoclásticas pelo Hac. A Figura 5.57 mostra o perfil temporal das velocidades aparentes $\left(\mathrm{r}_{\mathrm{ap}}\right)$ de utilização de substratos orgânicos, inclusive Hac, por BA, BRS e AM. Nessa figura, R1A representa a velocidade de utilização de S1 por BA - R2S representa a velocidade de utilização de S1 por BRS oxidadoras completas - R3M representa a velocidade de utilização de Hac por AM.

Inicialmente, os substratos orgânicos representados por S1 foram mais rapidamente consumidos por BRS oxidadoras completa. Portanto, essa foi a rota de degradação de S1 predominante no reator RE tratando meio sintético com Relação $\mathrm{DQO} / \mathrm{SO}_{4}{ }^{2-}$ de 3,2. A metanogênese ocorreu em baixa intensidade. De fato, a quantidade de metano produzida correspondeu a 3\% da quantidade teórica, considerando a eficiência média de remoção da DQO (67\%) e baseado na relação teórica, em massa, $\mathrm{CH}_{4} / \mathrm{DQO}$ igual a 0,25 (METCALF AND EDDY, 1991). 


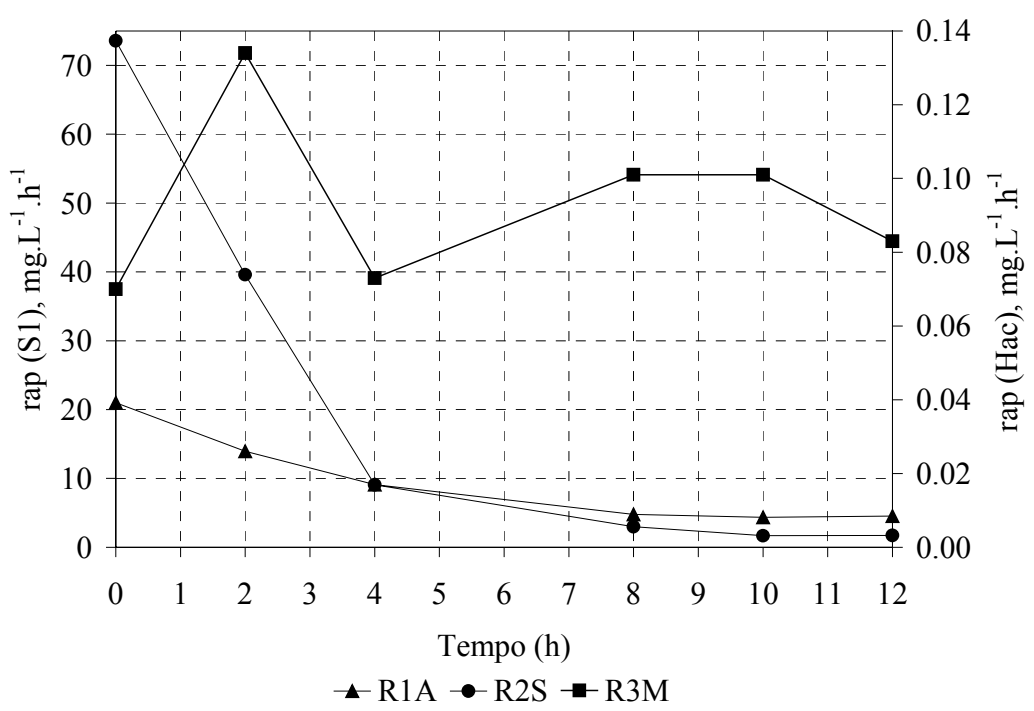

Figura 5.57. Perfil Temporal das Velocidades Aparentes, de Consumo de Substratos Orgânicos, no Reator com Espuma de Poliuretano Tratando Meio Sintético com Relação DQO/[ $\left.\mathrm{SO}_{4}{ }^{2-}\right]$ igual a 3,2 .

5.9.2 Reator com Espuma de Poliuretano (RE) Alimentado com Meio Sintético com Relação DQO/[ $\left.\mathrm{SO}_{4}{ }_{4}^{2-}\right]$ Igual a 1,3

A Tabela 5.25 apresenta os valores das variáveis representadas por CS1, CS2 e CS3, medidos em perfis temporais no reator RE tratando meio sintético com relação $\mathrm{DQO} /\left[\mathrm{SO}_{4}{ }^{2-}\right]$ igual a 1,3 , em condição de estabilidade em redução de sulfato. A Figura 5.58 apresenta o ajuste do modelo cinético aos valores empíricos, medidos até 12 horas de reação. No ajuste do modelo utilizou-se o intervalo de 12 horas para efeito de padronização nas três condições de relação DQO/[ $\left.\mathrm{SO}_{4}{ }^{2-}\right]$ avaliadas. 
Tabela 5. 25. PerfisTemporais das Variáveis: CS1, CS2, e CS3 no Reator com Espuma de Poliuretano Tratando Meio Sintético com Relação DQO/[ $\left.\mathrm{SO}_{4}{ }^{2-}\right]$ igual a 1,3 .

\begin{tabular}{cccc}
\hline $\begin{array}{c}\text { Tempo } \\
\mathrm{h}\end{array}$ & $\begin{array}{c}\mathrm{CS} 1 \\
\mathrm{mg} . \mathrm{L}^{-1}\end{array}$ & $\begin{array}{c}\mathrm{CS} 2 \\
\mathrm{mg} . \mathrm{L}^{-1}\end{array}$ & $\begin{array}{c}\mathrm{CS} 3 \\
\mathrm{mg} . \mathrm{L}^{-1}\end{array}$ \\
\hline 0 & 729 & 56 & 520 \\
2 & 419 & 129 & 370 \\
4 & n.a & 163 & 300 \\
6 & 301 & 166 & 270 \\
8 & 251 & 169 & 260 \\
10 & 286 & 157 & 200 \\
12 & 244 & 181 & 170 \\
14 & 280 & 141 & 130 \\
20 & 297 & 98 & 2 \\
24 & 259 & 111 & 12 \\
\hline
\end{tabular}

n.a.: Não Analisado

Observa-se na Figura 5.58 que o modelo cinético ajustou-se bem aos dados experimentais. Os testes de hipóteses indicaram similaridade, com significância de $5 \%$, entre os valores teóricos e observados experimentalmente. A Tabela 5.26 apresenta os valores das constantes cinéticas obtidos após o ajuste do modelo aos valores empíricos. 


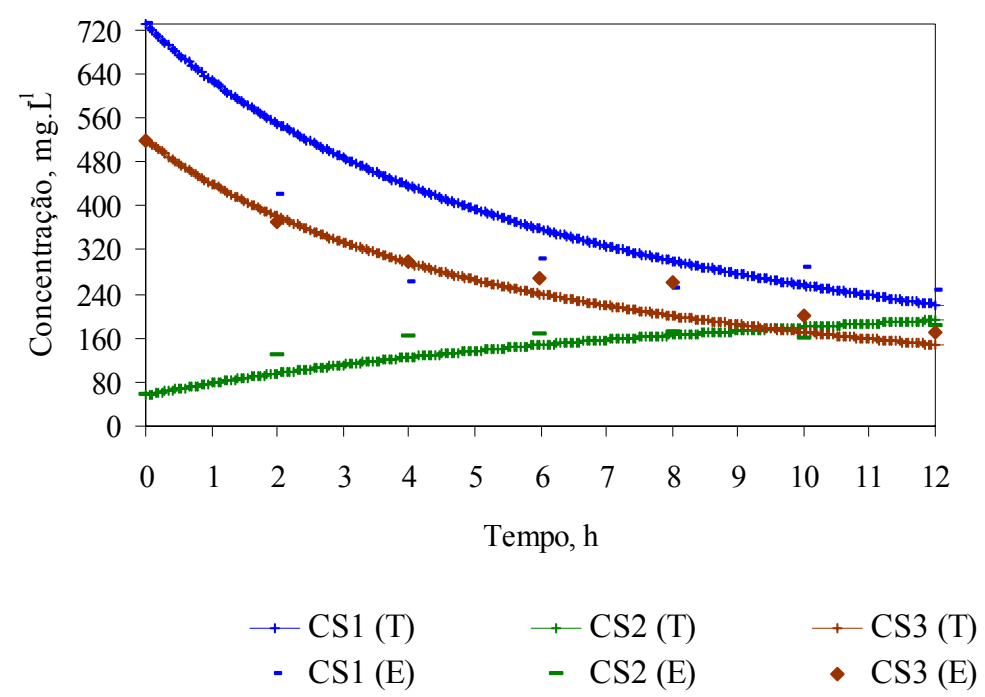

Figura 5.58. Ajuste do Modelo Cinético aos Valores Medidos nos Perfis Temporais das Variáveis: DQO, Ácido Acético como DQO e Sulfato no Reator com Espuma de Poliuretano Tratando Meio Sintético com Relação DQO/[ $\left.\mathrm{SO}_{4}{ }^{2-}\right]$ igual a 1,3.

Tabela 5.26. Valores das Constantes Cinéticas Calculados pelo Ajuste do Modelo Cinético aos Valores Medidos nos Perfis Temporais

\begin{tabular}{ccc}
\hline Constantes & Valores $\left(\times 10^{-4}\right)$ & Unidade \\
\hline $\mathrm{k}_{1 \mathrm{~A}}$ & 361 & $\mathrm{~h}^{-1}$ \\
$\mathrm{k}_{1 \mathrm{~S}}$ & 0 & $\mathrm{~L} \cdot \mathrm{mg}^{-1} \cdot \mathrm{h}^{-1}$ \\
$\mathrm{k}_{2 \mathrm{~S}}$ & 2 & $\mathrm{~L} \cdot \mathrm{mg}^{-1} \cdot \mathrm{h}^{-1}$ \\
$\mathrm{k}_{3 \mathrm{~S}}$ & 1 & $\mathrm{~L} \cdot \mathrm{mg}^{-1} \cdot \mathrm{h}^{-1}$
\end{tabular}

Os valores das constantes cinéticas indicam que: (i) parte de S1 foi oxidada a Hac por BA e parte foi oxidada a $\mathrm{CO}_{2}$ por BRS oxidadoras completas - (ii) Hac foi consumido exclusivamente por BRS acetoclásticas. Nesse modelo considerou-se somente a atividade sulfetogênica, uma vez que não foi detectado metano em amostras do biogás, nessa condição. A Figura 5.59 apresenta o perfil das velocidades aparentes $\left(\mathrm{r}_{\mathrm{ap}}\right)$ de consumo de substratos orgânicos por BA, BRS e AM no reator RE tratando meio sintético com relação $\mathrm{DQO} /\left[\mathrm{SO}_{4}{ }^{2-}\right]$ de 1,3 . 


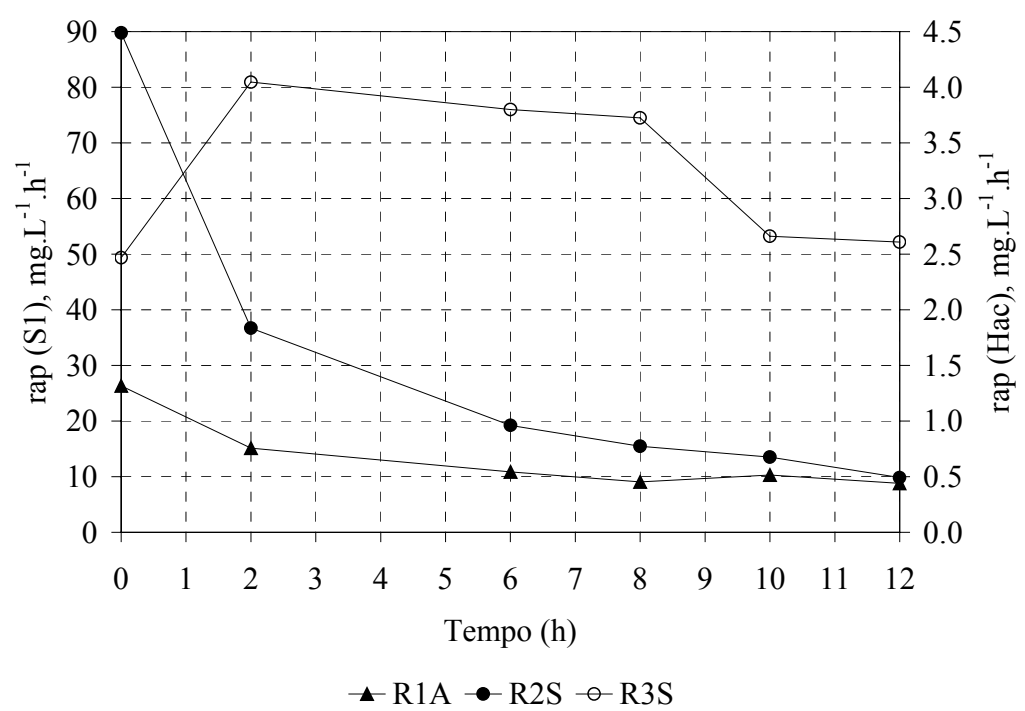

Figura 5.59. Perfil das Velocidades Aparentes, de Consumo de Substratos Orgânicos, no Reator com Espuma de Poliuretano (RE) Tratando Meio Sintético com Relação DQO/[SOS $\left.{ }^{2-}\right]$ igual a 1,3 .

Na Figura 5.59, R1A representa a velocidade de utilização de S1, por BA, R2S representa a velocidade de utilização de S1 por BRS oxidadoras completas, e R3S representa a velocidade de utilização de Hac por BRS acetoclásticas. Essa figura mostra como as reações sulfetogênicas foram predominantes em relação às reações conduzidas por BA, fato que resultou na melhor eficiência em redução de sulfato $(96 \%)$, observada no reator RE.

\subsubsection{Reator com Espuma de Poliuretano (RE) Alimentado com Meio Sintético com Relação DQO/[ $\left.\mathrm{SO}_{4}{ }_{4}^{2-}\right]$ Igual a 0,4}

A Tabela 5.27 apresenta os valores das variáveis representadas por CS1, CS2, e CS3, obtidos em perfis temporais no reator RE tratando meio sintético com relação $\mathrm{DQO} /\left[\mathrm{SO}_{4}{ }^{2-}\right]$ igual a 0,4 , em condição de estabilidade em redução de sulfato. A Figura 5.60 apresenta o ajuste do modelo cinético aos valores medidos nos perfis temporais, durante 12 horas de reação. 
Tabela 5.27. Perfil Temporal das Variáveis: CS1, CS2, e CS3, no Reator com Espuma de Poliuretano Tratando Meio Sintético com Relação DQO/[ $\left.\mathrm{SO}_{4}{ }^{2-}\right]$ igual a 0,4 .

\begin{tabular}{cccc}
\hline $\begin{array}{c}\text { Tempo } \\
\mathrm{h}\end{array}$ & $\begin{array}{c}\mathrm{CS} 1 \\
\mathrm{mg} . \mathrm{L}^{-1}\end{array}$ & $\begin{array}{c}\mathrm{CS} 2 \\
\mathrm{mg} . \mathrm{L}^{-1}\end{array}$ & $\begin{array}{c}\mathrm{CS} 3 \\
\mathrm{mg} . \mathrm{L}^{-1}\end{array}$ \\
\hline 0 & 660 & 17 & 1800 \\
2 & 441 & n.a. & 1650 \\
4 & 269 & 107 & 1600 \\
6 & 255 & 135 & 1400 \\
8 & 297 & 102 & 1300 \\
10 & n.a. & 75 & n.a. \\
12 & 308 & 66 & 1450 \\
\hline \multicolumn{4}{c}{ n.a.: Não Analisado }
\end{tabular}

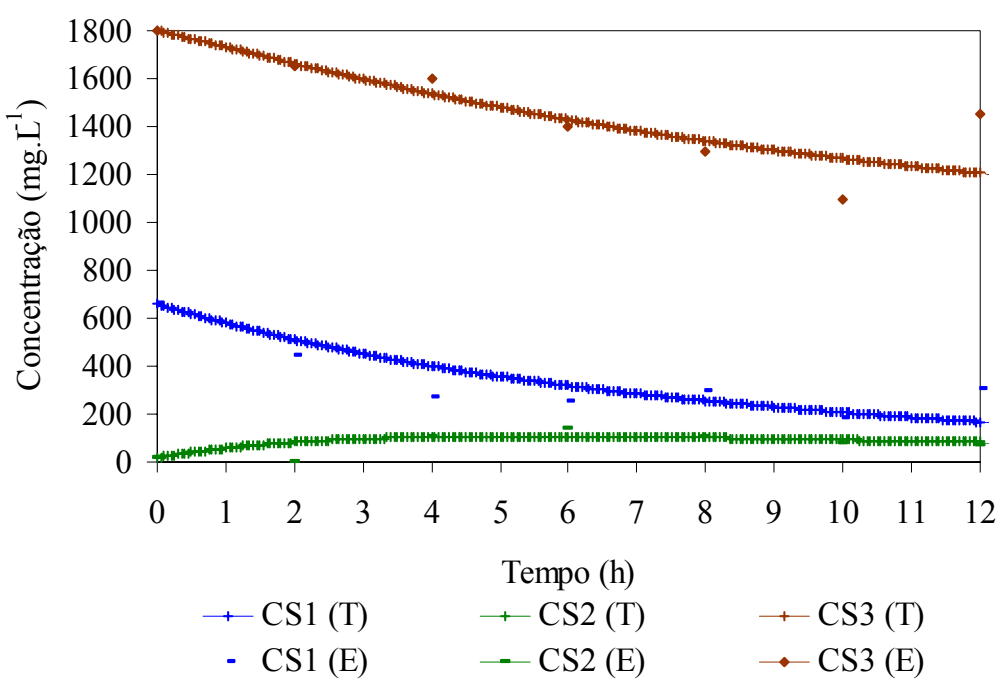

Figura 5.60. Ajuste do Modelo Cinético aos Valores Medidos nos Perfis Temporais das Variáveis: CS1, CS2 e CS3 no Reator com Espuma de Poliuretano (RE) Tratando Meio Sintético com Relação DQO/[ $\left.\mathrm{SO}_{4}{ }^{2-}\right]$ igual a 0,4 .

Observa-se na Figura 5.60 que o modelo cinético ajustou-se bem aos dados experimentais. Os testes de hipóteses indicaram similaridade entre os valores teóricos e experimentais com significância de 5\%. A Tabela 5.28 apresenta os valores das constantes cinéticas obtidos após o ajuste do modelo aos valores empíricos. 
Tabela 5.28. Valores das Constantes Cinéticas Calculados pelo Ajuste do Modelo aos Valores Medidos nos Perfis Temporais

\begin{tabular}{ccc}
\hline Constantes & Valores $\left(\times 10^{-4}\right)$ & Unidade \\
\hline $\mathrm{k}_{1 \mathrm{~A}}$ & 379 & $\mathrm{~h}^{-1}$ \\
$\mathrm{k}_{1 \mathrm{~S}}$ & 0 & $\mathrm{~L} \cdot \mathrm{mg}^{-1} \cdot \mathrm{h}^{-1}$ \\
$\mathrm{k}_{2 \mathrm{~S}}$ & 0 & $\mathrm{~L} \cdot \mathrm{mg}^{-1} \cdot \mathrm{h}^{-1}$ \\
$\mathrm{k}_{3 \mathrm{~S}}$ & 2 & $\mathrm{~L} \cdot \mathrm{mg}^{-1} \cdot \mathrm{h}^{-1}$ \\
\hline
\end{tabular}

Os valores das constantes cinéticas indicam que: (i) S1 foi oxidado a Hac por BA e este foi consumido por BRS acetoclásticas. Esses resultados refletem a pobre competitividade das BRS por substratos orgânicos em face das BA. Apesar de Hac ter sido utilizado como doador de elétrons por BRS, essa substância estava disponível em baixas concentrações, em comparação com a quantidade de sulfato presente, o que pode explicar a baixa eficiência do reator RE em redução de sulfato nessa condição.

A Figura 5.61 apresenta os perfis das velocidades de utilização de substratos orgânicos por BA e BRS no reator RE alimentado com meio sintético com relação $\mathrm{DQO} /\left[\mathrm{SO}_{4}{ }^{2-}\right]$ de 0,4 .

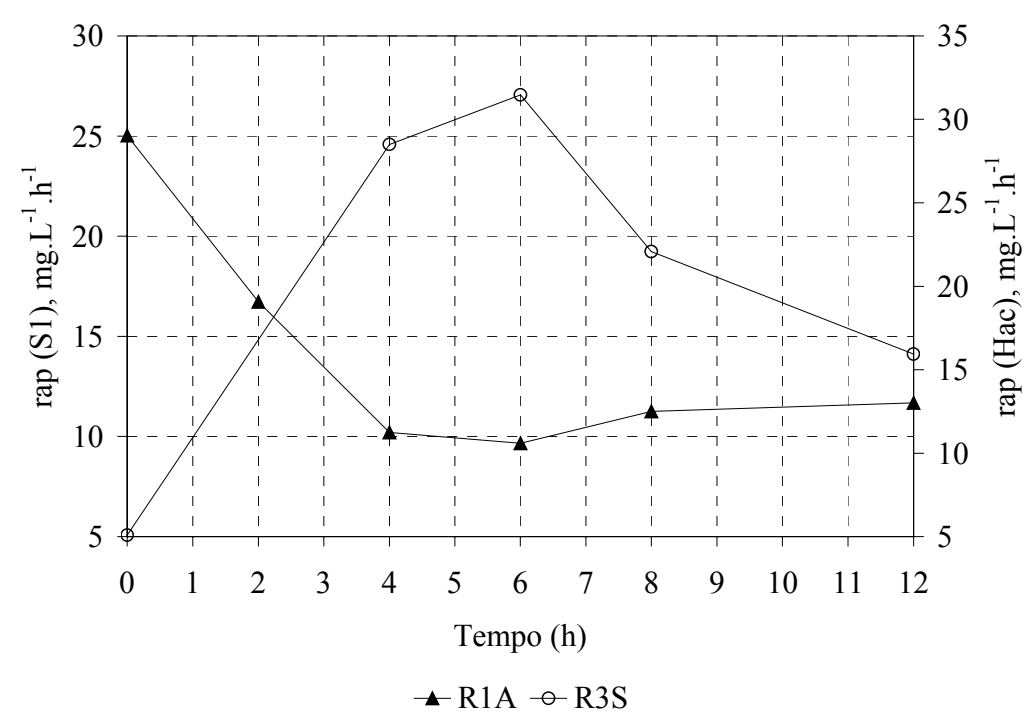

Figura 5.61. Perfil Temporal das Velocidades de Consumo de Substratos Orgânicos no Reator com Espuma de Poliuretano Tratando Meio Sintético com Relação

$$
\mathrm{DQO} /\left[\mathrm{SO}_{4}{ }^{2-}\right] \text { igual a } 0,4 \text {. }
$$


Na Figura 5.61, R1A representa a velocidade de utilização de S1 por BA, e R3S representa a velocidade de utilização de Hac por BRS. Conclui-se que houve sintrofismo entre BA e BRS.

\subsubsection{Reator com Carvão Vegetal (RC) Tratando Meio Sintético com Relação} $\underline{\mathrm{DQO} /\left[\mathrm{SO}_{4}{ }^{2-}\right] \text { Igual a } 3,2}$

A Tabela 5.29 apresenta os valores das variáveis representadas por CS1, CS2, e CS3, obtidos nos perfis temporais do reator RC tratando meio sintético com relação $\mathrm{DQO} /\left[\mathrm{SO}_{4}{ }^{2-}\right]$ igual a 3,2 , em condição de estabilidade em redução de sulfato. A Figura 4.62 apresenta o ajuste do modelo cinético aos valores medidos nos perfis temporais.

Tabela 5.29. Perfil Temporal das Variáveis Representadas por CS1, CS2, e CS3 no Reator com Carvão Vegetal (RC) Tratando Meio Sintético com Relação DQO/[SO ${ }_{4}{ }^{2-}$ ]igual a 3,2.

\begin{tabular}{cccc}
\hline Tempo & CS1 & CS2 & CS3 \\
\hline $\mathrm{h}$ & $\mathrm{mg} . \mathrm{L}^{-1}$ & $\mathrm{mg} . \mathrm{L}^{-1}$ & $\mathrm{mg} . \mathrm{L}^{-1}$ \\
\hline 0 & 528 & 63 & 283 \\
2 & 408 & 109 & n.a. \\
4 & 216 & 111 & 100 \\
6 & 170 & 81 & 60 \\
8 & 152 & 57 & 39 \\
10 & 165 & 35 & 21 \\
12 & 174 & 21 & 19 \\
\hline
\end{tabular}

n.a.: Não Analisado 


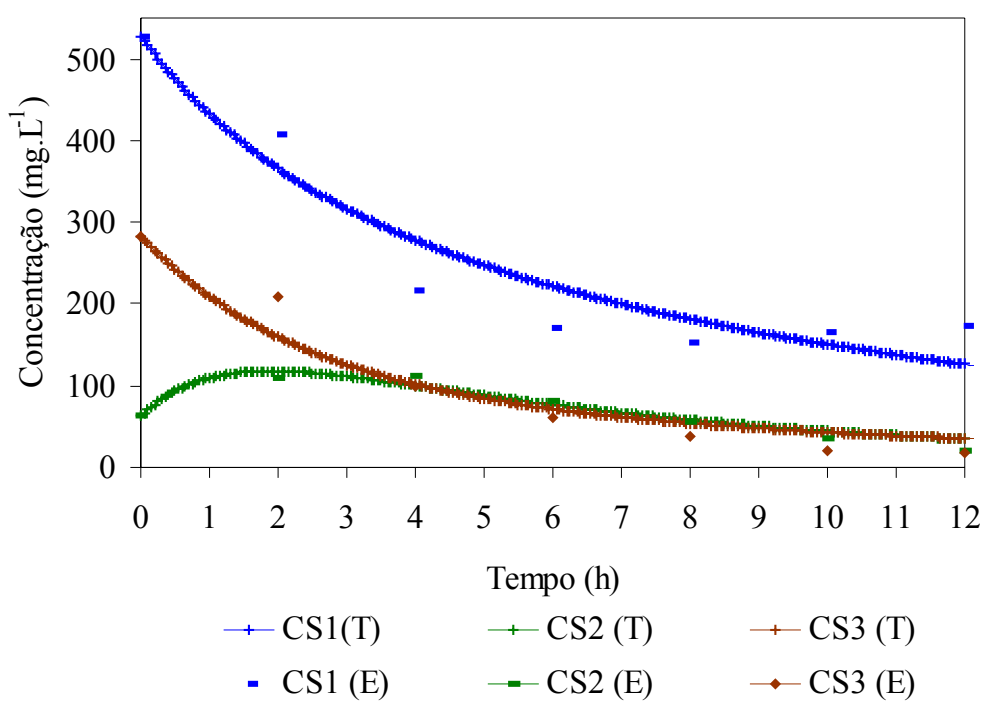

Figura 5.62. Ajuste do Modelo Cinético aos Valores Medidos nos Perfis Temporais das Variáveis: CS1, CS2 e CS3 no Reator com Carvão Vegetal (RC) Tratando Meio Sintético com Relação DQO/[ $\left.\mathrm{SO}_{4}{ }^{2-}\right]$ igual a 3,2.

Observa-se na Figura 5.62 que o modelo cinético ajustou-se bem aos dados experimentais. Os testes de hipóteses indicaram similaridade entre os valores teóricos e observados, com significância de 5\%. A Tabela 5.30 apresenta os valores das constantes cinéticas obtidos após o ajuste do modelo aos valores empíricos.

Tabela 5.30. Valores das Constantes Cinéticas Calculados pelo Ajuste do Modelo Cinético aos Valores das Variáveis Representadas por CS1, CS2, e CS3, Obtidos em Perfis Temporais no Reator com Carvão Vegetal Tratando Meio Sintético com Relação DQO/[ $\left.\mathrm{SO}_{4}\right]$ igual a 3,2.

\begin{tabular}{ccc}
\hline Constantes & Valores $\left(\times 10^{-4}\right)$ & Unidade \\
\hline $\mathrm{k}_{1 \mathrm{~A}}$ & 664 & $\mathrm{~h}^{-1}$ \\
$\mathrm{k}_{3 \mathrm{M}}$ & 4080 & $\mathrm{~h}^{-1}$ \\
$\mathrm{k}_{1 \mathrm{~S}}$ & 5 & $\mathrm{~L} \cdot \mathrm{mg}^{-1} \cdot \mathrm{h}^{-1}$ \\
$\mathrm{k}_{2 \mathrm{~S}}$ & 0 & $\mathrm{~L} \cdot \mathrm{mg}^{-1} \cdot \mathrm{h}^{-1}$ \\
$\mathrm{k}_{3 \mathrm{~S}}$ & 4 & L.mg ${ }^{-1} \cdot \mathrm{h}^{-1}$ \\
\hline
\end{tabular}

Os valores das constantes cinéticas indicam que: (i) S1 foi utilizado por BA e BRS oxidadoras incompletas - (3) Hac foi consumido por AM e BRS acetoclásticas. 
A Figura 5.63 apresenta o perfil das velocidades aparentes $\left(r_{a p}\right)$ de utilização de substratos orgânicos por BA, BRS e AM.

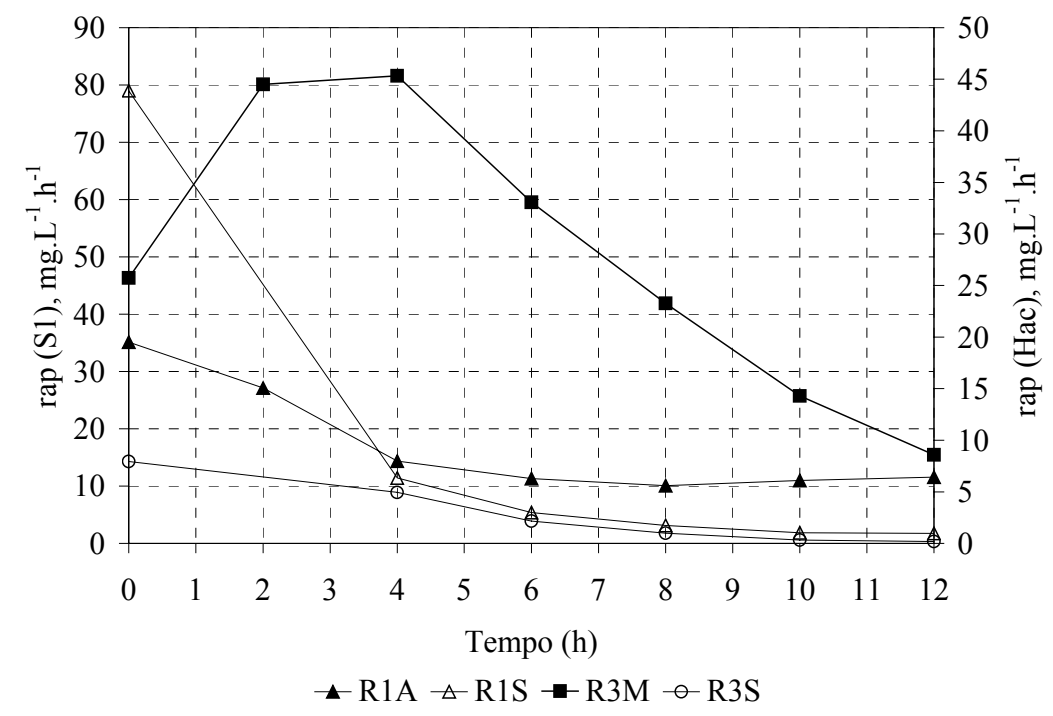

Figura 5.63. Perfil das Velocidades de Consumo de Substratos Orgânicos no Reator com Carvão Vegetal (RC) Tratando Meio Sintético com

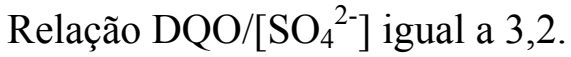

Na Figura 5.63, R1A representa a velocidade de utilização de S1 por BA R1S representa a velocidade de utilização de S1 por BRS oxidadoras incompletas $\mathrm{R} 3 \mathrm{M}$ representa a velocidade de utilização de Hac por $\mathrm{AM}$ - R3S representa a velocidade de utilização de Hac por BRS. Nessa figura pode ser observado que S1 foi mais rapidamente utilizado por BRS oxidadoras incompletas. AM consumiram mais rapidamente Hac do que BRS. De fato, a quantidade de metano produzida no reator $\mathrm{RC}$ tratando meio sintético com relação $\mathrm{DQO} /\left[\mathrm{SO}_{4}{ }^{2-}\right]$ igual a 3,2 foi dez vezes maior do que a quantidade produzida no reator RE, tratando meio sintético nas mesmas condições. Apesar da metanogênese ter sido predominante no reator RC, nessa condição, a eficiência média em redução de sulfato foi de $98 \%$.

5.9.5 Reator com Carvão Vegetal (RC) Alimentado com Meio Sintético com $\underline{\text { Relação DQO/[ }\left[\mathrm{SO}_{4}{ }_{4}^{2-}\right] \text { Igual a } 1,3}$

A Tabela 5.31 apresenta os valores das variáveis representadas por CS1, CS2, CS3 obtidos em perfis temporais no reator RC tratando meio sintético com relação 
$\mathrm{DQO} /\left[\mathrm{SO}_{4}{ }^{2-}\right]$ igual a 1,3 , em condição de estabilidade em redução de sulfato. A Figura 5.64 apresenta o ajuste do modelo cinético aos valores empíricos.

Tabela 5. 31. Perfil Temporal das Variáveis: CS1, CS2 e CS3 no Reator com Carvão Vegetal (RC) Tratando Meio Sintético com Relação DQO/[ $\left.\mathrm{SO}_{4}{ }^{2-}\right]$ igual a 1,3.

\begin{tabular}{cccc}
\hline Tempo & CS1 & CS2 & CS3 \\
\hline $\mathrm{h}$ & $\mathrm{mg} . \mathrm{L}^{-1}$ & $\mathrm{mg} . \mathrm{L}^{-1}$ & $\mathrm{mg} . \mathrm{L}^{-1}$ \\
\hline 0 & 735 & 15 & 600 \\
2 & 367 & 122 & 440 \\
4 & 267 & 142 & 330 \\
6 & 274 & 144 & 290 \\
8 & 276 & 123 & 240 \\
10 & 304 & 97 & 145 \\
12 & 295 & 66 & 95 \\
20 & 280 & 55 & 11 \\
24 & 244 & 68 & 10 \\
\hline
\end{tabular}

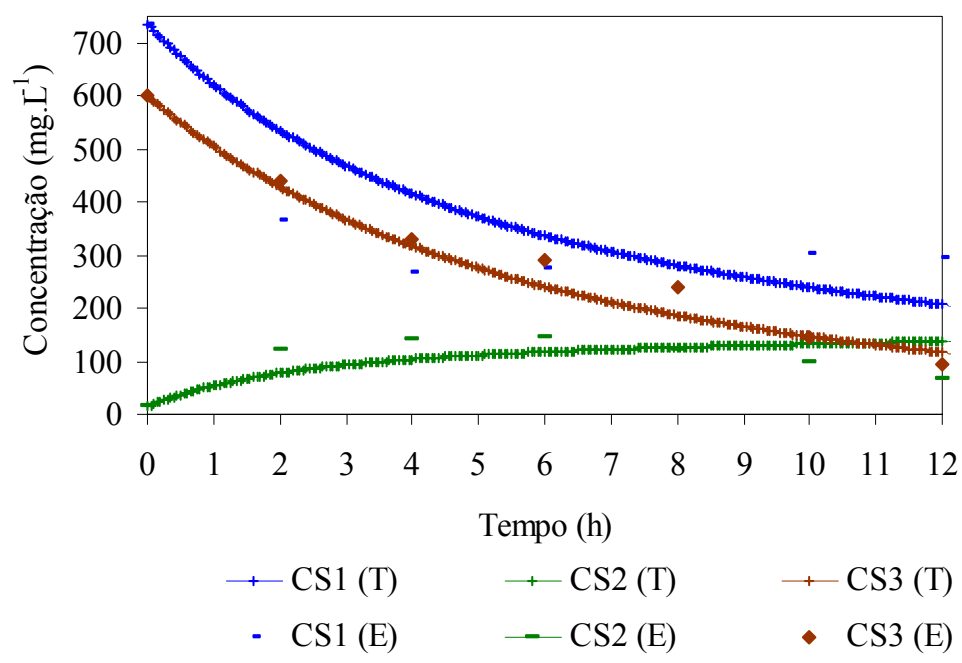

Figura 5.64. Ajuste do Modelo Cinético aos Valores Medidos nos Perfis Temporais das Variáveis: S1, S2 e S3 no Reator com Carvão Vegetal (RC) Tratando Meio Sintético com Relação DQO/[ $\left[\mathrm{SO}_{4}{ }^{2-}\right]$ igual a 1,3 . 
Observa-se na Figura 5.64 que o modelo cinético ajustou-se bem aos dados experimentais. Os testes estatísticos indicaram similaridade entre os valores teóricos e os observados, com significância de 5\%. A Tabela 5.32 apresenta os valores das constantes cinéticas obtidos após o ajuste do modelo aos valores empíricos.

Tabela 5.32. Valores das Constantes Cinéticas Calculados pelo Ajuste do Modelo Cinético aos Valores Medidos nos Perfis Temporais

\begin{tabular}{ccc}
\hline Constantes & Valores $\left(\times 10^{-4}\right)$ & Unidade \\
\hline $\mathrm{k}_{1 \mathrm{~A}}$ & 416 & $\mathrm{~h}^{-1}$ \\
$\mathrm{k}_{1 \mathrm{~S}}$ & 0 & $\mathrm{~h}^{-1}$ \\
$\mathrm{k}_{2 \mathrm{~S}}$ & 2 & $\mathrm{~L} \cdot \mathrm{mg}^{-1} \cdot \mathrm{h}^{-1}$ \\
$\mathrm{k}_{3 \mathrm{~S}}$ & 5 & $\mathrm{~L} \cdot \mathrm{mg}^{-1} \cdot \mathrm{h}^{-1}$
\end{tabular}

Os valores das constantes cinéticas indicam que: (1) S1 foi utilizado por BA e BRS oxidadoras completas - (2) BRS acetoclásticas consumiram, o Hac gerado na acidogênese. A Figura 5.65 apresenta o perfil das velocidades de utilização de substratos orgânicos por BA, BRS e AM.

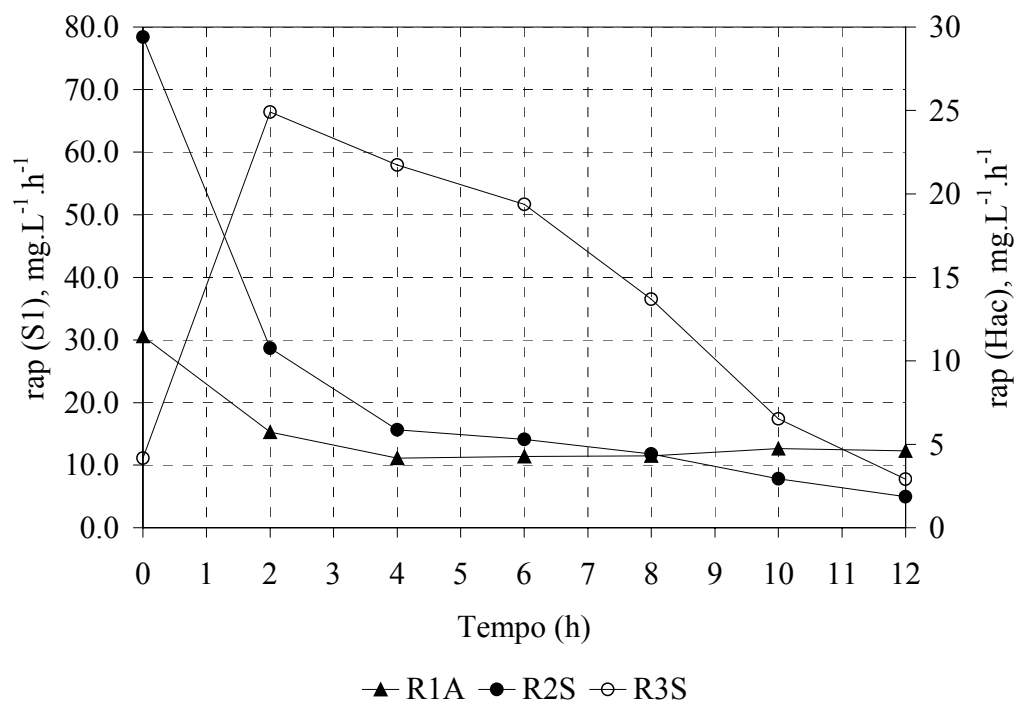

Figura 5.65. Perfis Temporais das Velocidades de Consumo de Substratos Orgânicos no Reator com Carvão Vegetal Tratando Meio Sintético com Relação DQO/[ $\left.\mathrm{SO}_{4}{ }^{2-}\right]$ igual a 1,3 . 
Na Figura 5.65, R1A representa a velocidade de utilização S1 por BA - R2S representa a velocidade de utilização de S1 por BRS oxidadoras completas - R3S representa a velocidade de utilização de Hac por BRS. S1 foi consumido mais rapidamente por BRS oxidadoras completas.

\subsubsection{Reator com Carvão Vegetal (RC) Alimentado com Meio Sintético com $\left.\underline{\text { Relação DQO/[SO }}{ }_{4}^{2-}\right]$ Igual a 0,4}

A Tabela 5.33 apresenta os valores das variáveis representadas por CS1, CS2, e CS3, obtidos em perfis temporais no reator RC tratando meio sintético com relação $\mathrm{DQO} /\left[\mathrm{SO}_{4}{ }^{2-}\right]$ igual a 0,4 em condição de estabilidade em redução de sulfato.

Tabela 5. 33. Perfil Temporal das Variáveis: CS1, CS2 e CS3 no Reator com Carvão Vegetal (RC) Tratando Meio Sintético com Relação DQO/[ $\left.\mathrm{SO}_{4}{ }^{2-}\right]$ igual a 0,4.

\begin{tabular}{cccc}
\hline $\begin{array}{c}\text { Tempo } \\
\mathrm{h}\end{array}$ & $\mathrm{CS} 1$ & $\mathrm{CS} 2$ & $\mathrm{CS} 3$ \\
$\mathrm{mg.L^{-1 }}$ & $\mathrm{mg.L^{-1 }}$ & $\mathrm{mg.L^{-1 }}$ \\
\hline 0 & 622 & 21 & 1750 \\
2 & n.a. & 93 & 1550 \\
4 & 267 & 116 & 1400 \\
6 & 254 & 147 & 1500 \\
8 & 359 & 93 & 1300 \\
10 & 347 & 55 & 1200 \\
12 & 271 & 47 & 1300 \\
\hline
\end{tabular}

A Figura 5.66 apresenta o ajuste do modelo cinético aos valores medidos nos perfis temporais. 


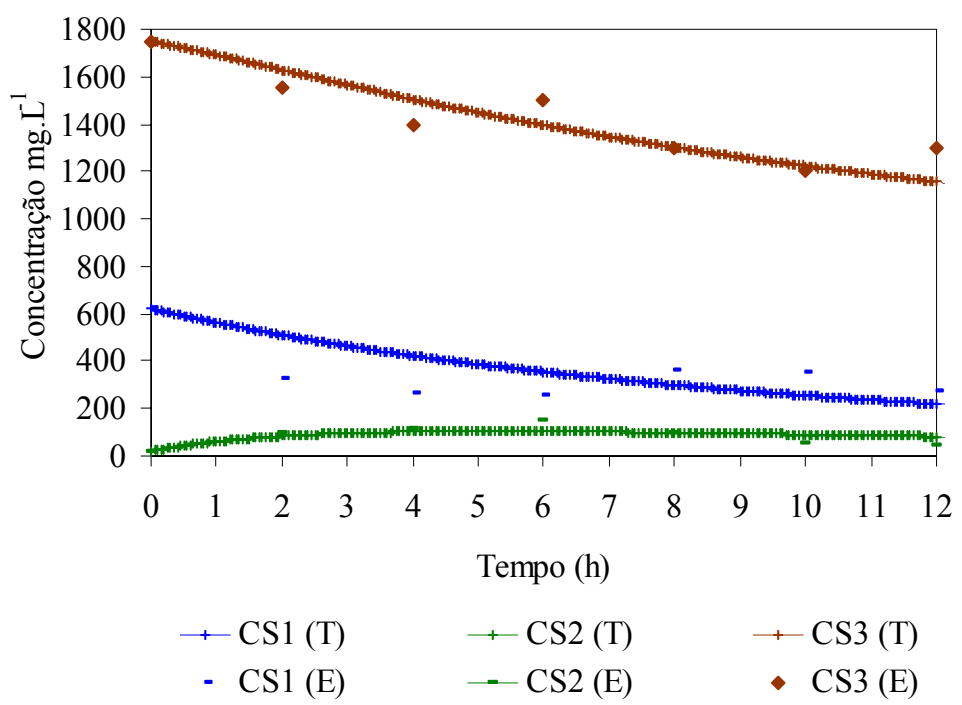

Figura 5.66. Ajuste do Modelo Cinético aos Valores Medidos nos Perfis Temporais das Variáveis: CS1, CS2, e CS3 no Reator com Carvão Vegetal (RC) Tratando Meio Sintético com Relação DQO/[ $\left[\mathrm{SO}_{4}{ }^{2-}\right]$ igual a 0,4 .

Observa-se na Figura 5.66 que o modelo cinético ajustou-se bem aos dados experimentais. Os testes estatísticos indicaram similaridade entre os valores medidos e os valores calculados pelo modelo cinético, com significância de 5\%. A Tabela 5.34 apresenta os valores das constantes cinéticas obtidos após o ajuste do modelo aos valores empíricos.

Tabela 5.34. Valores das Constantes Cinéticas Calculados pelo Ajuste do Modelo Cinético aos Valores Medidos nos Perfis Temporais no Reator com Carvão Vegetal Tratando Meio Sintético com Relação DQO/[ $\left[\mathrm{SO}_{4}{ }^{2-}\right]$ igual a 0,4.

\begin{tabular}{ccc}
\hline Constantes & Valores $\left(\times 10^{-3}\right)$ & Unidade \\
\hline $\mathrm{k}_{1 \mathrm{~A}}$ & 266 & $\mathrm{~h}^{-1}$ \\
$\mathrm{k}_{1 \mathrm{~S}}$ & 0 & $\mathrm{~L} \cdot \mathrm{mg}^{-1} \cdot \mathrm{h}^{-1}$ \\
$\mathrm{k}_{2 \mathrm{~S}}$ & 0 & $\mathrm{~L} \cdot \mathrm{mg}^{-1} \cdot \mathrm{h}^{-1}$ \\
$\mathrm{k}_{3 \mathrm{~S}}$ & 2 & $\mathrm{~L} \cdot \mathrm{mg}^{-1} \cdot \mathrm{h}^{-1}$ \\
\hline
\end{tabular}

Os valores das constantes cinéticas indicam que: (i) S1 foi consumido predominantemente por BA - (2) Hac foi preferencialmente consumido por BRS 
acetoclásticas. A Figura 5.67 apresenta o perfil das velocidades de utilização de substratos orgânicos por BA, BRS e AM.

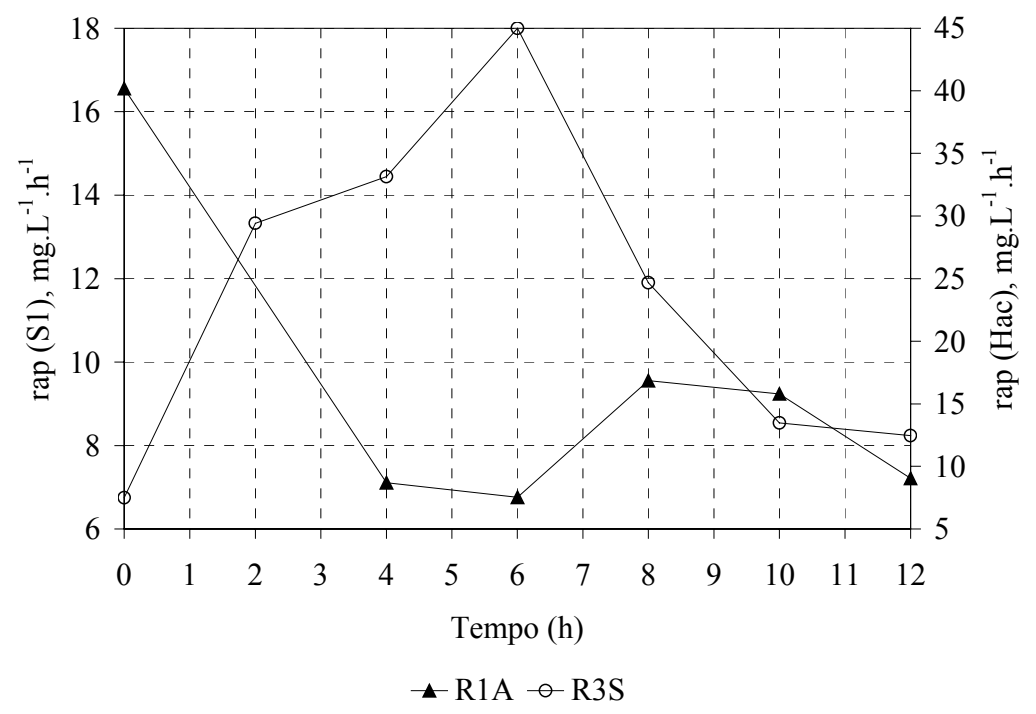

Figura 5.67. Perfil das Velocidades de Consumo de Substratos Orgânicos no Reator com Carvão Vegetal (RC) Tratando Meio Sintético com Relação DQO/[ $\left.\mathrm{SO}_{4}{ }^{2-}\right]$ igual a 0,4 .

Na Figura 5.67, R1A representa a velocidade de consumo S1 por BA - R3S representa a velocidade de consumo de Hac por BRS.

\subsubsection{Considerações Gerais Sobre a Modelação Cinética}

A Tabela 5.35 apresenta a comparação dos parâmetros cinéticos determinados para o reator RE, tratando água residuária sintética com relações $\mathrm{DQO} /\left[\mathrm{SO}_{4}{ }^{2-}\right]$ iguais a $3,2,1,3$, e 0,4 .

O modelo cinético proposto indicou que houve atividade metanogênica acetoclástica apenas quando a relação $\mathrm{DQO} /\left[\mathrm{SO}_{4}{ }^{2-}\right]$ da água residuária sintética foi igual a 3,2. Todavia, a quantidade de metano detectada no biogás nessa condição foi baixa (11 mg. $\left.\mathrm{L}^{-1}\right)$, indicando predominância da sulfetogênese. Esses resultados corroboram a avaliação microbiana por hibridação in situ com fluorescência (FISH) que indicou predominância do Domínio Bactéria (74,5\% das células coradas com DAPI) sobre o Domínio Archaea (23,8\% das células coradas com DAPI). 
Tabela 5.35. Comparação dos Parâmetros Cinéticos Determinados para o ASBBR Contendo Espuma de Poliuretano Tratando Água Residuária Sintética com Relação $\mathrm{DQO} /\left[\mathrm{SO}_{4}{ }^{2-}\right]$ igual a $3,2,1,3$, e 0,4 .

\begin{tabular}{cccccc}
\hline $\begin{array}{c}\text { Relação } \\
\mathrm{DQO} /\left[\mathrm{SO}_{4}{ }^{2-}\right]\end{array}$ & $\begin{array}{c}\mathrm{k}_{1 \mathrm{~A}} \\
\left(\mathrm{~h}^{-1}\right)\end{array}$ & $\begin{array}{c}\mathrm{k}_{3 \mathrm{M}} \\
\left(\mathrm{h}^{-1}\right)\end{array}$ & $\begin{array}{c}\mathrm{k}_{1 \mathrm{~S}} \\
\mathrm{~L} \cdot \mathrm{mg}^{-1} \cdot \mathrm{h}^{-1}\end{array}$ & $\begin{array}{c}\mathrm{k}_{2 \mathrm{~S}} \\
\mathrm{~L} \cdot \mathrm{mg}^{-1} \cdot \mathrm{h}^{-1}\end{array}$ & $\begin{array}{c}\mathrm{k}_{3 \mathrm{~S}} \\
\mathrm{~L} \cdot \mathrm{mg}^{-1} \cdot \mathrm{h}^{-1}\end{array}$ \\
\hline 3,2 & $4,03 \times 10^{-2}$ & $1,00 \times 10^{-3}$ & 0 & $7,00 \times 10^{-4}$ & 0 \\
1,3 & $3,61 \times 10^{-2}$ & n.d. & $2 \times 10^{-4}$ & $2,00 \times 10^{-4}$ & $1,00 \times 10^{-4}$ \\
0,4 & $3,79 \times 10^{-2}$ & n.d. & 0 & 0 & $2,00 \times 10^{-4}$ \\
\hline
\end{tabular}

n.d.: Não Determinado

Nas outras duas condições, água residuária sintética com relação $\mathrm{DQO} /\left[\mathrm{SO}_{4}{ }^{2-}\right]$ igual a 1,3 e 0,4 , o modelo presumiu que não houve metanogênese. De fato, não foi detectado metano em amostras do biogás durante a operação dos ASBBR's tratando água residuária sintética com relação $\mathrm{DQO} /\left[\mathrm{SO}_{4}{ }^{2-}\right]$ igual a $1,3 \mathrm{e}$ 0,4 e não foram detectadas arqueas pela sonda ARC915 na avaliação por FISH em $\mathrm{PU}$ após o tratamento de água residuária sintética com relação $\mathrm{DQO} /\left[\mathrm{SO}_{4}{ }^{2-}\right]$ igual a 0,4. A comunidade microbiana desenvolvida durante o tratamento de água residuária sintética com relação DQO/[ $\left.\mathrm{SO}_{4}{ }^{2-}\right]$ igual a 1,3 não foi avaliada por FISH. Todavia, os valores das constantes cinéticas determinadas para as condições de água residuária sintética com relação DQO/[ $\left.\mathrm{SO}_{4}{ }^{2-}\right]$ igual a 1,3 e 0,4 foram iguais. Esses resultados sugerem que nessas duas condições as AM foram inibidas.

O modelo cinético utilizado também indicou que, durante o tratamento de esgoto sintético com relação $\mathrm{DQO} /\left[\mathrm{SO}_{4}{ }^{2-}\right]$ igual a 3,2 , a atividade sulfetogênica foi conduzida somente pelas BRS oxidadoras completas. Esse fato pode estar associado com interações sintróficas entre BRS e BA. De acordo com MIZUNO et al. (1998), as BRS desempenham importante papel na transferência de $\mathrm{H}_{2}$ interespécies É possível que a matéria orgânica adicionada tenha sido convertida em intermediários, como, por exemplo, propionato, butirato e acetato pelas BA e, nesse caso, as BRS competiram com AM pelo hidrogênio produzido. As BRS apresentam vantagem termodinâmica na competição por hidrogênio com AM e bactérias homoacetogênicas (MIZUNO et al., 1998). Os valores da variação de energia livre em condições 
padronizadas ( $\mathrm{pH}$ neutro e todos os reagentes em concentração $1 \mathrm{M}$ ), indicado por $\Delta G^{o \prime}$, para as reações de consumo de hidrogênio por esses microrganismos, são: -151,9kJ/reação, -135,6 kJ/reação, e -104kJ/reação, respectivamente.

$\mathrm{Na}$ condição de tratamento de água residuária sintética com relação $\mathrm{DQO} /\left[\mathrm{SO}_{4}{ }^{2-}\right]$ igual a 3.2 , as BRS não competiram por acetato com AM. De acordo com ISA et al. (1986), espécies de AM apresentaram vantagem sobre BRS marinhas na competição por acetato. Esses autores observaram que somente acetato como doador de elétrons não foi conveniente para BRS, porém, esses microrganismos apresentaram vantagem sobre AM na competição por acetato quando foi utilizada uma mistura de etanol e acetato como doador de elétrons. Uma possível explicação para esse fato é o baixo valor da variação de energia livre envolvendo a utilização de acetato por BRS ( $\Delta G^{\circ \prime}$ igual a $-47 \mathrm{~kJ} /$ reação). Esse valor de $\Delta G^{\circ \prime}$, apresentado por ISA et al. (1986), resulta em rendimento energético cerca de 3 vezes menor do que o valor para a reação envolvendo o consumo de $\mathrm{H}_{2}$ por BRS.

$\mathrm{Na}$ condição de tratamento de água residuária sintética com relação $\mathrm{DQO} /\left[\mathrm{SO}_{4}{ }^{2-}\right]$ igual a 0,4 o modelo cinético utilizado implicou que além da atividade metanogênica a sulfetogênese também foi inibida, com exceção das BRS acetoclásticas. De fato, o ASBBR contendo PU apresentou o pior desempenho em redução de sulfato durante o tratamento de água residuária sintética com relação $\mathrm{DQO} /\left[\mathrm{SO}_{4}{ }^{2-}\right]$ igual a $0,4(31 \%)$, ao contrário do que ocorreu no tratamento de água residuária sintética com relação $\mathrm{DQO} /\left[\mathrm{SO}_{4}{ }^{2-}\right]$ igual a 1,3 . Nessa condição a eficiência em redução de sulfato foi, em média, 96\%, o melhor desempenho observado.

De acordo com os parâmetros cinéticos determinados na condição de tratamento com água residuária sintética com relação $\mathrm{DQO} /\left[\mathrm{SO}_{4}{ }^{2-}\right]$ igual a 1,3 , as BRS oxidadoras incompletas competiram com as BA pela matéria orgânica adicionada e com as $\mathrm{AM}$ por $\mathrm{H}_{2}$ (Tabela 4.36). Na condição de tratamento de água residuária com relação $\mathrm{DQO} /\left[\mathrm{SO}_{4}{ }^{2-}\right]$ igual a 0,4 o modelo cinético indicou que as BA levaram vantagem sobre as BRS na competição pela matéria orgânica adicionada e as BRS utilizaram somente Hac como doador de elétrons e fonte de carbono, em reação com baixo rendimento de energia ( $\Delta G^{\circ}$ igual a $-47 \mathrm{~kJ} /$ reação), o que pode justificar a baixa eficiência em redução de sulfato. Esses resultados corroboram as observações na comunidade microbiana analisadas por FISH, segundo as quais 
houve predomínio dos microrganismos pertencentes ao Domínio Eubactéria (85\% das células coradas com DAPI) e a porcentagem média de BRS identificadas pela sonda SRB385, pertencentes ao Domínio Eubactéria, correspondeu a 21\% das células coradas com DAPI. Em outras palavras, o número de BRS foi $64 \%$ inferior ao número de BA. A Tabela 5.36 apresenta a comparação dos parâmetros cinéticos determinados para o ASBBR contendo $\mathrm{CV}$ como material suporte, tratando água residuária sintética com relação $\mathrm{DQO} /\left[\mathrm{SO}_{4}{ }^{2-}\right]$ igual a 3,2, 1,3, e 0,4.

Tabela 5.36. Comparação dos Parâmetros Cinéticos Determinados para o ASBBR Contendo Carvão Vegetal Tratando Água Residuária Sintética com Relação $\mathrm{DQO} /\left[\mathrm{SO}_{4}{ }^{2-}\right]$ igual a $3,2,1,3$, e 0,4 .

\begin{tabular}{cccccc}
\hline $\begin{array}{c}\text { Relação } \\
\mathrm{DQO} /\left[\mathrm{SO}_{4}{ }^{2-}\right]\end{array}$ & $\begin{array}{c}\mathrm{k}_{1 \mathrm{~A}} \\
\left(\mathrm{~h}^{-1}\right)\end{array}$ & $\begin{array}{c}\mathrm{k}_{3 \mathrm{M}} \\
\left(\mathrm{h}^{-1}\right)\end{array}$ & $\begin{array}{c}\mathrm{k}_{1 \mathrm{~S}} \\
\mathrm{~L} \cdot \mathrm{mg}^{-1} \cdot \mathrm{h}^{-1}\end{array}$ & $\begin{array}{c}\mathrm{k}_{2 \mathrm{~S}} \\
\mathrm{~L} \cdot \mathrm{mg}^{-1} \cdot \mathrm{h}^{-1}\end{array}$ & $\begin{array}{c}\mathrm{k}_{3 \mathrm{~S}} \\
\mathrm{~L} \cdot \mathrm{mg}^{-1} \cdot \mathrm{h}^{-1}\end{array}$ \\
\hline 3,2 & $6,64 \times 10^{-2}$ & $4,08 \times 10^{-1}$ & $5,00 \times 10^{-4}$ & 0 & $4,00 \times 10^{-4}$ \\
1,3 & $4,16 \times 10^{-2}$ & n.d. & 0 & $2,00 \times 10^{-4}$ & $5,00 \times 10^{-4}$ \\
0,4 & $2,66 \times 10^{-2}$ & n.d. & 0 & 0 & $2,00 \times 10^{-4}$ \\
\hline
\end{tabular}
n.d. - Não Determinado.

No reator RC, o ajuste do modelo cinético aos dados experimentais indicou que, na condição de tratamento de água residuária sintética com relação $\mathrm{DQO} /\left[\mathrm{SO}_{4}{ }^{2-}\right]$ igual a 3,2, a sulfetogênese foi conduzida somente por BRS oxidadoras incompletas de substratos orgânicos, as quais competiram com BA pela matéria orgânica adicionada. Os valores das constantes cinéticas determinadas para as reações mediadas pelas BA e BRS imobilizadas em $\mathrm{CV}$ foram maiores do que aqueles determinados com a biomassa imobilizada em PU. Igualmente ao observado no reator RE, a metanogênese acetoclástica ocorreu somente quando o reator $\mathrm{RC}$ tratou água residuária sintética com relação $\mathrm{DQO} /\left[\mathrm{SO}_{4}{ }^{2-}\right]$ igual a 3,2. Nessa condição houve competição entre BRS e AM pelo acetato disponível.

Os valores das constantes cinéticas determinadas para o consumo de Hac por AM e BRS imobilizadas em CV foram maiores do que os valores observados com esses microrganismos imobilizados em PU. No caso da metanogênese, foi observado que a concentração de metano no biogás do ASBBR contendo CV foi cerca de dez 
vezes superior à concentração observada no biogás do ASBBR contendo PU. Entretanto, a avaliação microbiana por FISH indicou que a população de AM em CV foi em média $14 \%$, enquanto que em PU foi em média $24 \%$ do total de células coradas com DAPI. Dessa forma, a maior atividade metanogênica no ASBBR contendo $\mathrm{CV}$, indicada pela concentração de metano no biogás e pelo maior valor da constante cinética ( $\mathrm{k}_{3 \mathrm{M}}$ na Tabela 4.36) não está associada com quantidade específica de AM aderidas, mas, pode estar associada com a quantidade total de biomassa no reator.

O modelo cinético presumiu que, durante o tratamento de água residuária sintética com relação $\mathrm{DQO} /\left[\mathrm{SO}_{4}{ }^{2-}\right]$ igual a 1,3 no reator $\mathrm{RC}$, ocorreu interação sintrófica entre BA produtoras de $\mathrm{H}_{2}$ e BRS consumidoras de $\mathrm{H}_{2}$ e interação competitiva entre AM e BRS acetoclásticas. Esses resultados indicam que a matéria orgânica adicionada foi completamente oxidada a $\mathrm{CO}_{2}$, via redução de sulfato, e a metano. Entretanto, a eficiência em remoção de DQO no reator RC (56\%) foi inferior à observada no reator RE $(61 \%)$ e o desempenho em redução de sulfato foi igual nesses dois reatores $(96 \%)$.

Os parâmetros cinéticos obtidos para o reator $\mathrm{RC}$ tratando água residuária com relação $\mathrm{DQO} /\left[\mathrm{SO}_{4}{ }^{2-}\right]$ igual a 0,4 indica predomínio da sulfetogênese e esse processo ocorreu por conta das BRS acetoclásticas da mesma forma que no reator RE.

Os resultados obtidos na análise cinética indicam que para o processo de biodessulfatação, o tratamento de água residuária sintética com relação $\mathrm{DQO} /\left[\mathrm{SO}_{4}{ }^{2-}\right]$ igual a 1,3 foi a melhor condição. Sulfato foi reduzido a sulfeto por BRS oxidadoras incompletas de substratos orgânicos, oxidadoras completas de substratos orgânicos e acetoclásticas. De fato, os melhores desempenhos em redução de sulfato dos ASBBR's contendo biomassa imobilizada em PU e CV (96\%) foram observados quando esses reatores trataram água residuária sintética com relação $\mathrm{DQO} /\left[\mathrm{SO}_{4}{ }^{2-}\right]$ igual a 1,3 . 


\subsection{Modelação Cinética - Alimentação dos Reatores com Meio Sintético com Relação DQO/[SO $\left.{ }_{4}{ }^{2-}\right]$ Igual a 0,4 e com Adição de Etanol}

A seguir são apresentados os resultados da modelação cinética dos reatores $\mathrm{RE}$ e $\mathrm{RC}$ alimentados com meio sintético com relação $\mathrm{DQO} /\left[\mathrm{SO}_{4}{ }^{2-}\right]$ igual a 0,4 e suplementado com etanol, adicionado em quantidade estequiométrica em relação à concentração de sulfato.

\subsubsection{Reator com Espuma de Poliuretano (RE)}

A Tabela 5.37 apresenta os valores das variáveis: CS1, CS2, e CS3, obtidos nos perfis temporais do reator $\mathrm{RE}$ tratando meio sintético com relação $\mathrm{DQO} /\left[\mathrm{SO}_{4}{ }^{2-}\right]$ igual a 0,4 , suplementado com etanol em quantidade estequiométrica em relação a $\left[\mathrm{SO}_{4}{ }^{2-}\right]$, operando em condição de estabilidade em redução de sulfato.

A Figura 5.68 apresenta o ajuste do modelo cinético aos valores medidos nos perfis temporais. Os testes estatísticos aplicados indicaram similaridade entre os valores teóricos e experimentais com significância de 5\%. A Tabela 5.38 apresenta os valores das constantes cinéticas obtidos após o ajuste do modelo aos valores empíricos.

Tabela 5.37. Perfil Temporal das Variáveis: CS1, CS2, e CS3 no Reator com Espuma de Poliuretano Tratando Meio Sintético com Relação

$\mathrm{DQO} /\left[\mathrm{SO}_{4}{ }^{2-}\right]$ igual a 0,4 e Etanol

\begin{tabular}{ccccc}
\hline $\begin{array}{c}\text { Tempo } \\
\mathrm{h}\end{array}$ & $\begin{array}{c}\mathrm{CS} 1 \\
\mathrm{mg} . \mathrm{L}^{-1}\end{array}$ & $\begin{array}{c}\mathrm{CS} 2 \\
\mathrm{mg} . \mathrm{L}^{-1}\end{array}$ & $\begin{array}{c}\mathrm{CS} 3 \\
\mathrm{mg} . \mathrm{L}^{-1}\end{array}$ & $\begin{array}{c}\text { Etanol } \\
\mathrm{mg} . \mathrm{L}^{-1}\end{array}$ \\
\hline 0 & 1585 & 281 & 1740 & 512 \\
2 & 1899 & 498 & 1140 & 294 \\
4 & 1538 & 997 & 900 & 35 \\
6 & 1398 & 614 & 740 & 6 \\
8 & 1492 & 1047 & 680 & 1 \\
10 & 1910 & 1871 & 680 & 1 \\
12 & 1247 & 1058 & 540 & 1 \\
14 & 1398 & 1411 & 480 & 0 \\
23 & 1631 & 1635 & 400 & 0 \\
24 & 1841 & 824 & 400 & 0 \\
\hline
\end{tabular}




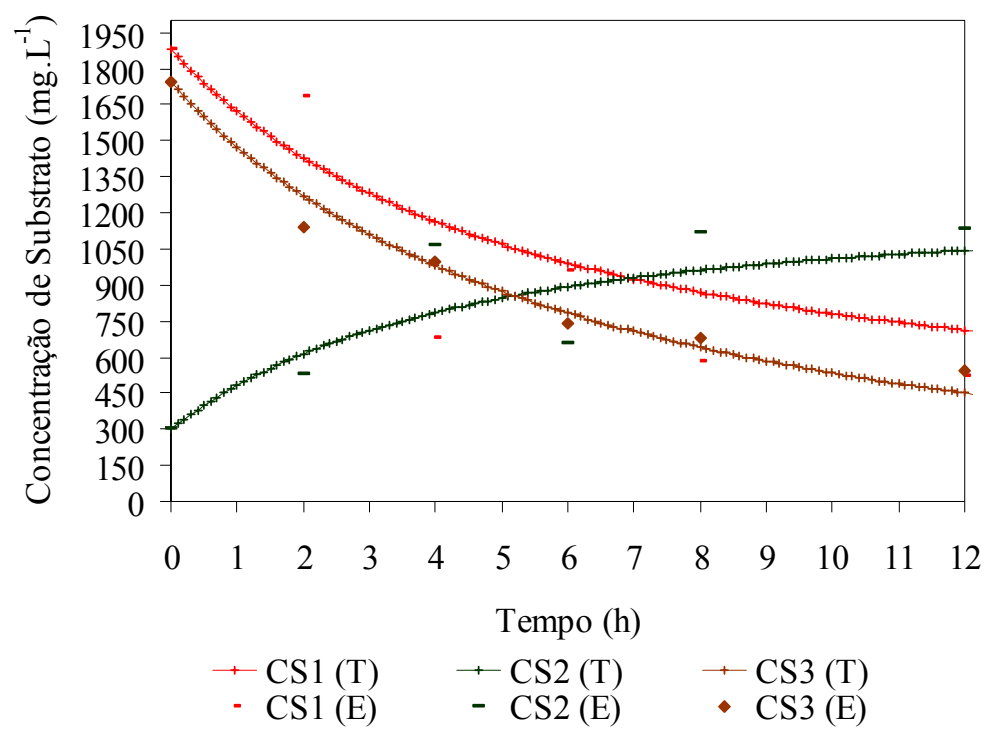

Figura 5.68. Ajuste do Modelo Cinético aos Valores Medidos nos Perfis Temporais das Variáveis: CS1, CS2 e CS3 no Reator com Espuma de Poliuretano (RE) Tratando Meio Sintético com Relação DQO/[ $\left.\mathrm{SO}_{4}{ }^{2-}\right]$ igual a 0,4 e Etanol.

Tabela 5.38. Valores das Constantes Cinéticas Calculados pelo Ajuste do Modelo Cinético aos Valores Medidos nos Perfis Temporais no Reator RE Alimentado com Meio Sintético com Relação DQO/[ $\left.\mathrm{SO}_{4}{ }^{2-}\right]$ igual a 0,4 e Etanol.

\begin{tabular}{ccc}
\hline Constantes & Valores $\left(\times 10^{-4}\right)$ & Unidade \\
\hline $\mathrm{k}_{1 \mathrm{~A}}$ & 0 & $\mathrm{~h}^{-1}$ \\
$\mathrm{~K}_{1 \mathrm{~S}}$ & 1 & $\mathrm{~L} \cdot \mathrm{mg}^{-1} \cdot \mathrm{h}^{-1}$ \\
$\mathrm{~K}_{2 \mathrm{~S}}$ & 0 & $\mathrm{~L} \cdot \mathrm{mg}^{-1} \cdot \mathrm{h}^{-1}$ \\
$\mathrm{~K}_{3 \mathrm{~S}}$ & 0 & $\mathrm{~L} \cdot \mathrm{mg}^{-1} \cdot \mathrm{h}^{-1}$
\end{tabular}

Os valores das constantes cinéticas indicam que S1 foi utilizado somente por BRS oxidadoras incompletas, pois as outras constantes tiveram valor nulo. A Figura 4.69 apresenta o perfil da velocidade de utilização de S1 por BRS. 


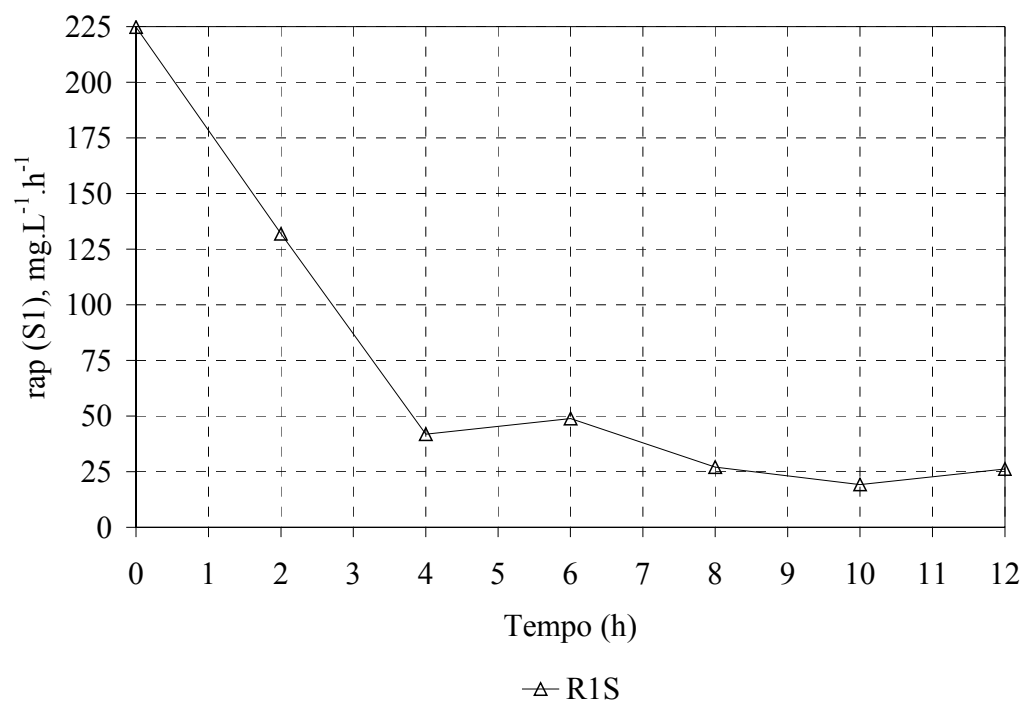

Figura 5.69. Perfil Temporal da Velocidade Aparente, de Consumo de Substratos Orgânicos $\left(\mathrm{r}_{\mathrm{ap}}\right)$ no Reator com Espuma de Poliuretano Tratando Meio Sintético com Relação DQO/[SO $\left.{ }_{4}^{2-}\right]$ igual a 0,4 .

A Figura 5.69 mostra que os substratos orgânicos foram oxidados incompletamente por BRS e Hac acumulou no reator, nessa condição.

\subsubsection{Reator com Carvão Vegetal (RC)}

A Tabela 5.39 apresenta os valores das variáveis representadas por CS1, CS2, e CS3, obtidos em perfis temporais no reator RC tratando meio sintético com relação $\mathrm{DQO} /\left[\mathrm{SO}_{4}{ }^{2-}\right]$ igual a 0,4 , suplementado com etanol em quantidade estequiométrica em relação a $\left[\mathrm{SO}_{4}{ }^{2-}\right]$, operando em condição de estabilidade em redução de sulfato. A Figura 5.70 apresenta o ajuste do modelo cinético aos valores medidos nos perfis temporais. O modelo cinético ajustou-se bem aos dados experimentais. Os testes estatísticos indicaram similaridade entre os conjuntos de valores teóricos e experimentais, com significância de 5\%. A Tabela 5.40 apresenta os valores das constantes cinéticas obtidos após o ajuste do modelo aos valores medidos experimentalmente. 
Tabela 5.39. Perfil Temporal das Variáveis: CS1, CS2 e CS3 no Reator com Carvão

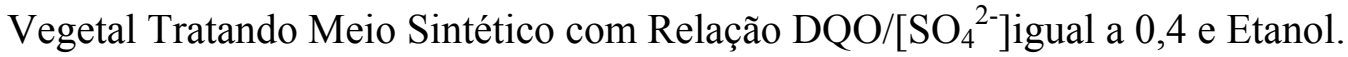

\begin{tabular}{ccccc}
\hline $\begin{array}{c}\text { Tempo } \\
\mathrm{h}\end{array}$ & $\begin{array}{c}\mathrm{CS} 1 \\
\mathrm{mg} . \mathrm{L}^{-1}\end{array}$ & $\begin{array}{c}\mathrm{CS} 2 \\
\mathrm{mg} . \mathrm{L}^{-1}\end{array}$ & $\begin{array}{c}\mathrm{CS} 3 \\
\mathrm{mg} . \mathrm{L}^{-1}\end{array}$ & $\begin{array}{c}\text { Etanol } \\
\mathrm{mg} . \mathrm{L}^{-1}\end{array}$ \\
\hline 0 & 1794 & 471 & 1740 & 631 \\
2 & 1899 & 693 & 1120 & 369 \\
4 & 1480 & 577 & 1000 & 152 \\
6 & 1631 & 1495 & 700 & 34 \\
8 & 1748 & 962 & 620 & 8 \\
10 & 1538 & 1637 & 560 & $\mathrm{n} . \mathrm{a}$. \\
12 & 1445 & 1568 & 560 & 6 \\
14 & 1410 & 1547 & 420 & 0 \\
23 & 1259 & 849 & 360 & 0 \\
24 & 1911 & 1072 & 360 & 0
\end{tabular}

n.a.: Não Analisado

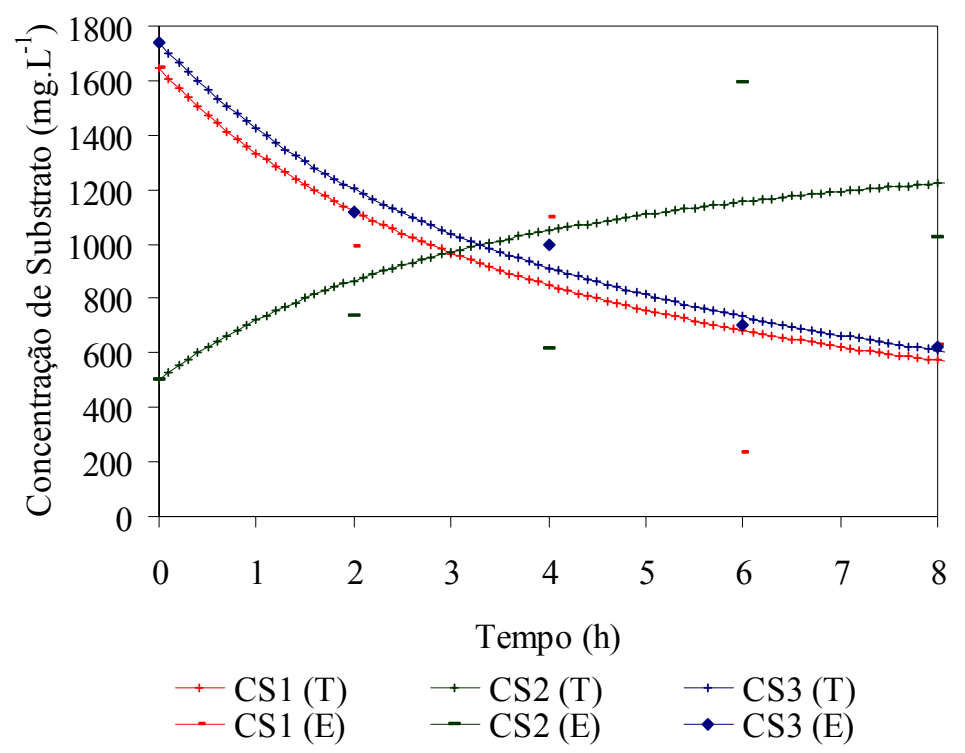

Figura 5.70. Ajuste do Modelo Cinético aos Valores Medidos nos Perfis Temporais das Variáveis: DQO, Hac como DQO e Sulfato no Reator com Carvão Vegetal Tratando Meio Sintético com Relação DQO/[ $\left[\mathrm{SO}_{4}{ }^{2-}\right]$ igual a 0,4. 
Tabela 5.40. Valores das Constantes Cinéticas Calculados pelo Ajuste do Modelo Cinético aos Valores Medidos nos Perfis Temporais

\begin{tabular}{ccc}
\hline Constantes & Valores $\left(\mathrm{x} \mathrm{10}^{-4}\right)$ & Unidade \\
\hline $\mathrm{k}_{1 \mathrm{~A}}$ & 0 & $\mathrm{~h}^{-1}$ \\
$\mathrm{~K}_{1 \mathrm{~S}}$ & 1 & $\mathrm{~L} \cdot \mathrm{mg}^{-1} \cdot \mathrm{h}^{-1}$ \\
$\mathrm{~K}_{2 \mathrm{~S}}$ & 0 & $\mathrm{~L} \cdot \mathrm{mg}^{-1} \cdot \mathrm{h}^{-1}$ \\
$\mathrm{~K}_{3 \mathrm{~S}}$ & 0 & $\mathrm{~L} \cdot \mathrm{mg}^{-1} \cdot \mathrm{h}^{-1}$ \\
\hline
\end{tabular}

Os valores das constantes cinéticas indicam que, praticamente, toda a matéria orgânica adicionada foi convertida a Hac por BRS oxidadoras incompletas, com tendência ao acúmulo desse ácido. A Figura 5.71 apresenta o perfil das velocidades aparentes de consumo $\left(\mathrm{r}_{\mathrm{ap}}\right) \mathrm{S} 1$ por BA e de Hac por BRS.

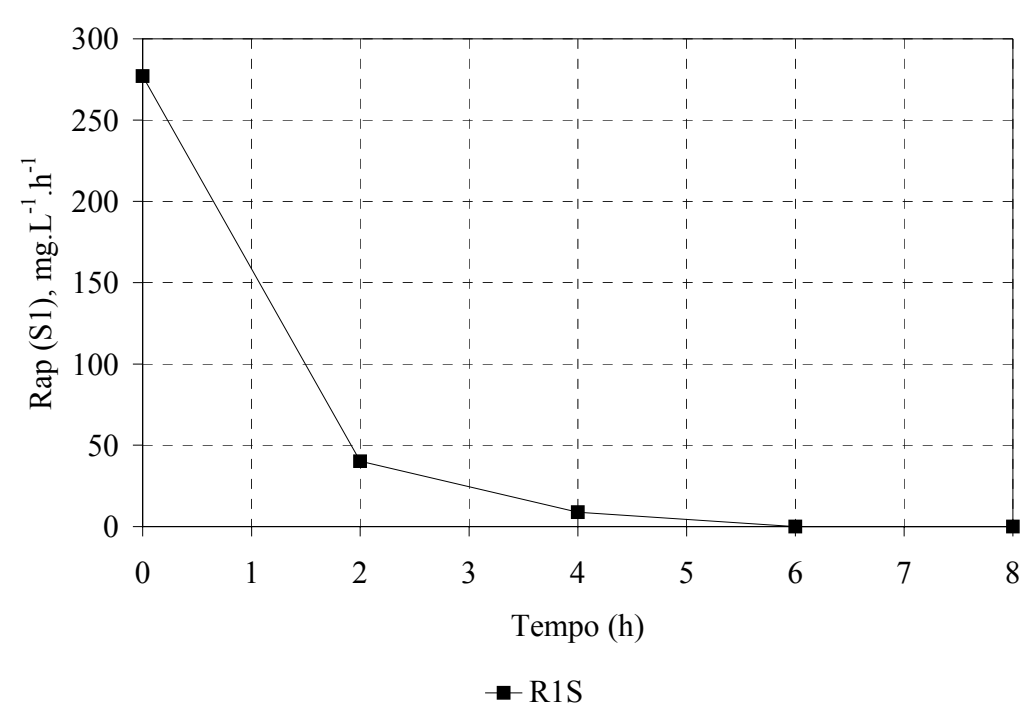

Figura 5.71. Perfil da Velocidades de Utilização de S1 por BRS no Reator com Carvão Vegetal Tratando Meio Sintético com Relação DQO/[ $\left.\mathrm{SO}_{4}{ }^{2-}\right]$ igual a 0,4.

\subsection{Oxidação Parcial do Sulfeto em Reator Aeróbio}

Nessa etapa, os reatores sulfetogênico, ASBBR (R1) e aeróbio, SBBR (R2) foram monitorados durante 80 ciclos de 24 horas. A Tabela 5.41 apresenta os resultados do monitoramento das variáveis: $\left[\mathrm{SO}_{4}{ }^{2-}\right]$, [ST] e OD.

Até o $39^{\circ}$ ciclo $\mathrm{R} 1$ foi alimentado com meio sintético com $\left[\mathrm{SO}_{4}{ }^{2-}\right]$ média de $790 \mathrm{mg} . \mathrm{L}^{-1}$ e DQO média de $1110 \mathrm{mg} . \mathrm{L}^{-1}$, correspondendo à relação $\mathrm{DQO} /\left[\mathrm{SO}_{4}{ }^{2-}\right]$ de 
1,4. Nessa condição, a eficiência média em redução de sulfato foi $52 \%$, gerando sulfeto em concentração de $134 \pm 70 \mathrm{mg} . \mathrm{L}^{-1}$. Nesse período, R2 apresentou eficiência média em remoção de sulfeto igual a $88 \%$ (concentração de sulfeto remanescente de $\left.16 \pm 9 \mathrm{mg} \cdot \mathrm{L}^{-1}\right) . \mathrm{A}\left[\mathrm{SO}_{4}{ }^{2-}\right]$ remanescente nesse reator foi $470 \mathrm{mg} \cdot \mathrm{L}^{-1}$.

Tabela 5.41. Valores das Variáveis: $\left[\mathrm{SO}_{4}{ }^{2-}\right]$, [ST] e OD nos reatores ASBBR (R1) e $\operatorname{SBBR}(\mathrm{R} 2)$

\begin{tabular}{ccccccc}
\hline & \multicolumn{3}{c}{$\begin{array}{c}\left.\mathrm{SO}_{4}{ }^{2-}\right] \\
\left(\mathrm{mg} . \mathrm{L}^{-1}\right)\end{array}$} & \multicolumn{3}{c}{$\mathrm{ST}$} \\
$\left(\mathrm{mg} . \mathrm{L}^{-1}\right)$ & $\begin{array}{c}\text { OD } \\
\left(\mathrm{mg} . \mathrm{L}^{-1}\right)\end{array}$ \\
\hline Ciclos & Afluente & $\mathrm{R} 1$ & $\mathrm{R} 2$ & $\mathrm{R} 1$ & $\mathrm{R} 2$ & $\mathrm{R} 2$ \\
\hline 15 & n.a. & 390 & 420 & 46 & 33 & n.a. \\
22 & 850 & 520 & 320 & 48 & 5 & 0,50 \\
25 & n.a. & 310 & 690 & 192 & 16 & n.a. \\
29 & 775 & 360 & 680 & 81 & 14 & 0,06 \\
31 & n.a. & 340 & 440 & 199 & 14 & 0,10 \\
32 & n.a. & 270 & 370 & 226 & 23 & 0,05 \\
38 & 750 & 397 & 398 & 133 & 10 & 0,06 \\
39 & n.a. & 419 & 468 & 147 & 14 & n.a. \\
52 & n.a. & 68 & 116 & 140 & 36 & 0,05 \\
59 & n.a. & 69 & 144 & 178 & 10 & 0,05 \\
76 & n.a. & 35 & 251 & 184 & 43 & 0,40 \\
80 & n.a. & 24 & 163 & 256 & 61 & 0,10 \\
\hline & & n.a. - Não Analisado & &
\end{tabular}

Esses resultados indicaram que cerca de $20 \%$ do sulfeto gerado no reator sulfetogênico foram reoxidados a sulfato devido à introdução de ar, quando a concentração de OD foi superior a $0,1 \mathrm{mg} . \mathrm{L}^{-1}$ e $68 \%$ foram oxidados parcialmente a enxofre elementar, desprezando-se a quantidade de enxofre utilizada para a síntese celular. 
A Figura 5.72 apresenta a variação da $\left[\mathrm{SO}_{4}{ }^{2-}\right]$ nos reatores $\mathrm{R} 1$ e $\mathrm{R} 2$, e a Figura 5.73 apresenta a variação na [ST] nos reatores R1 e R2, e o desempenho do reator $\mathrm{R} 2$, em remoção de sulfeto.

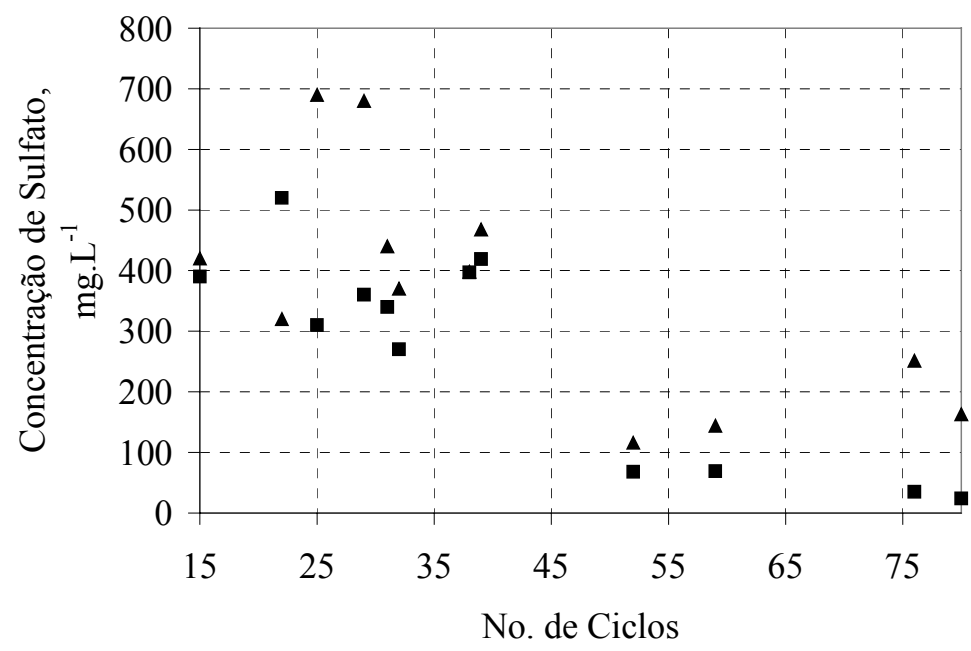

- $\mathrm{R} 1 \Delta \mathrm{R} 2$

Figura 5. 72. Concentração de Sulfato nos Reatores Sulfetogênico (R1) e Aeróbio (R2) ao Longo dos Ciclos Realizados.

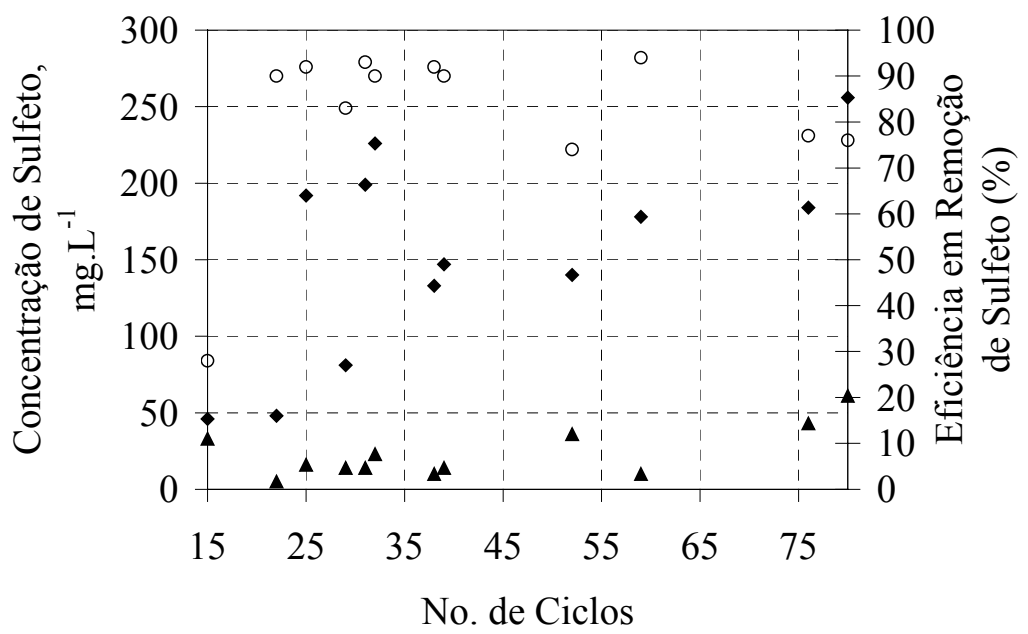

- R1 $\triangle \mathrm{R} 2 \circ \mathrm{ER} 2$

Figura 5.73. Concentração de Sulfeto nos Reatores Sulfetogênico (R1) e Aeróbio (R2), e da Eficiência em Remoção de Sulfeto no Reator Aeróbio (ER2) ao Longo dos Ciclos Realizados. 
A partir do $40^{\circ}$ ciclo, etanol passou a ser adicionado como doador de elétrons suplementar ao meio sintético, em quantidade estequiométrica em relação à [ $\left.\mathrm{SO}_{4}{ }^{2-}\right]$ (relação etanol/[ $\left.\mathrm{SO}_{4}{ }^{2-}\right]$ igual a 0,67 ). Nessa condição a eficiência em redução de sulfato aumentou para 94\% em R1, gerando sulfeto em concentração média igual a $190 \pm 50$ mg.L $L^{-1}$. A eficiência em remoção de sulfeto em R2, nessa condição, foi igual a $80 \%$.

Quando R2 apresentou estabilidade em redução de sulfeto, realizou-se o perfil temporal nesse reator. Os valores de sulfeto medidos foram utilizados para ajuste de modelo cinético de primeira ordem e obtenção da constante cinética de consumo de sulfeto. A Figura 5.74 apresenta o ajuste do modelo cinético de primeira ordem aos valores de concentração de sulfeto medidos.

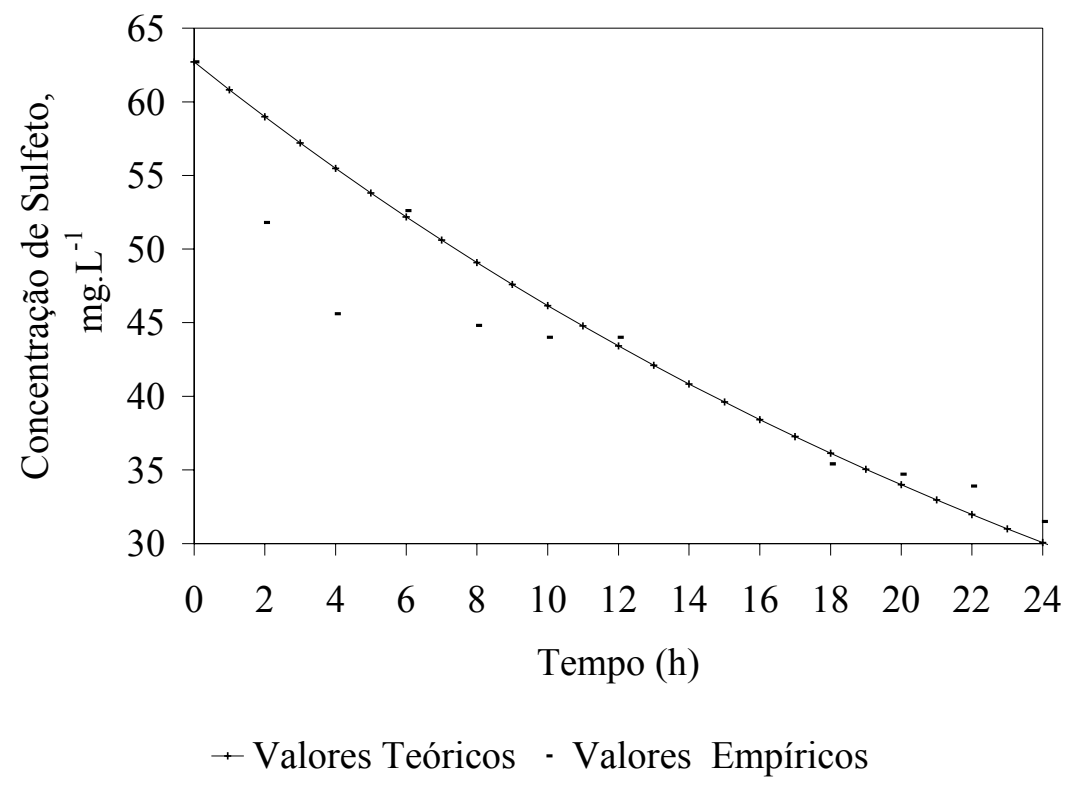

Figura 5.74. Ajuste de Modelo Cinético de Primeira Ordem aos Valores de Concentração de Sulfeto Total Obtidos no Perfil Temporal do Reator R2.

O ajuste do modelo cinético de primeira ordem aos dados experimentais foi adequado, conforme os resultados dos testes estatísticos aplicados (análise de resíduos seguida pelo teste de valores extremos com base nos desvios) com significância de $5 \%$. O valor da constante cinética de primeira ordem aparente $\left(k_{a p}\right)$ obtido para o consumo de sulfeto no processo foi $0,03 \mathrm{~h}^{-1}$. 
As Figuras 5.75 a 5.77 apresentam os resultados da quantificação de enxofre elementar pela técnica de fluorescência de raios $\mathrm{X}$ com dispersão de energia (EDXRF) em amostras de sólidos desprendidos de amostras do MS e coletadas na superfície, meio e fundo do SBBR. As energias emitidas pelos átomos dos elementos da amostra $(\mathrm{O}, \mathrm{Si}, \mathrm{Na}$ e $\mathrm{S})$ como resultado da excitação causada pela exposição aos raios X são representadas pelas abscissas. No eixo das ordenadas são representadas as intensidades de detecção dessas energias. Esses valores são proporcionais a quantidade de cada elemento presente em cada amostra analisada, apresentados na Tabela 5.42.

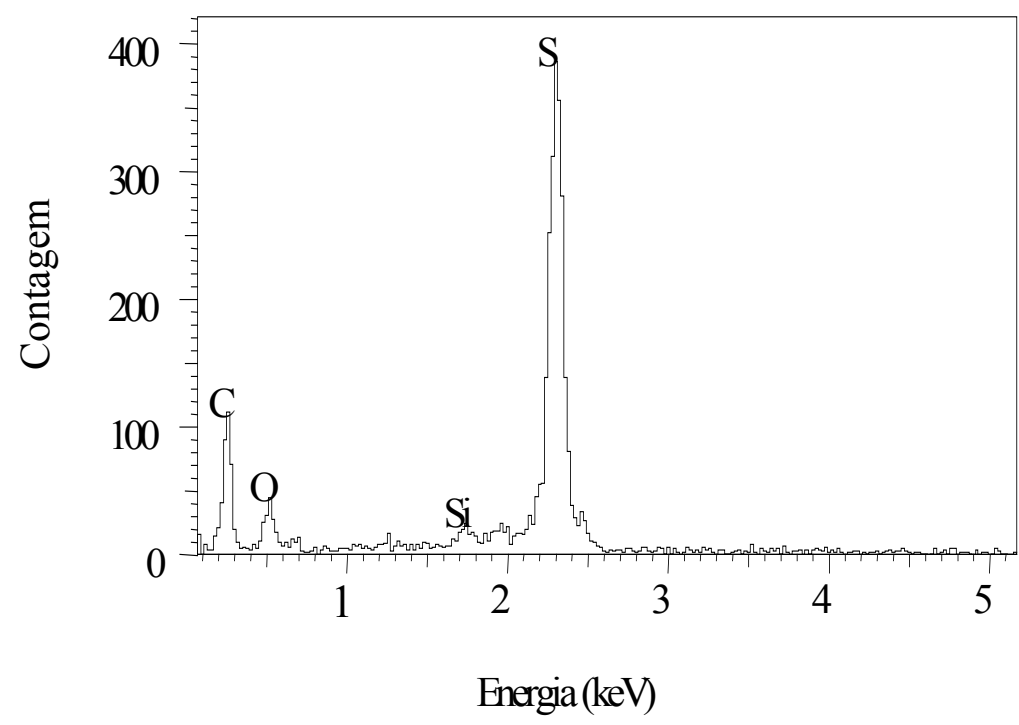

Figura 5.75. Intensidade da Quantidade de Energia Detectada pelo Equipamento de EDXRF em Amostras Coletadas na Altura Superior do Reator. 


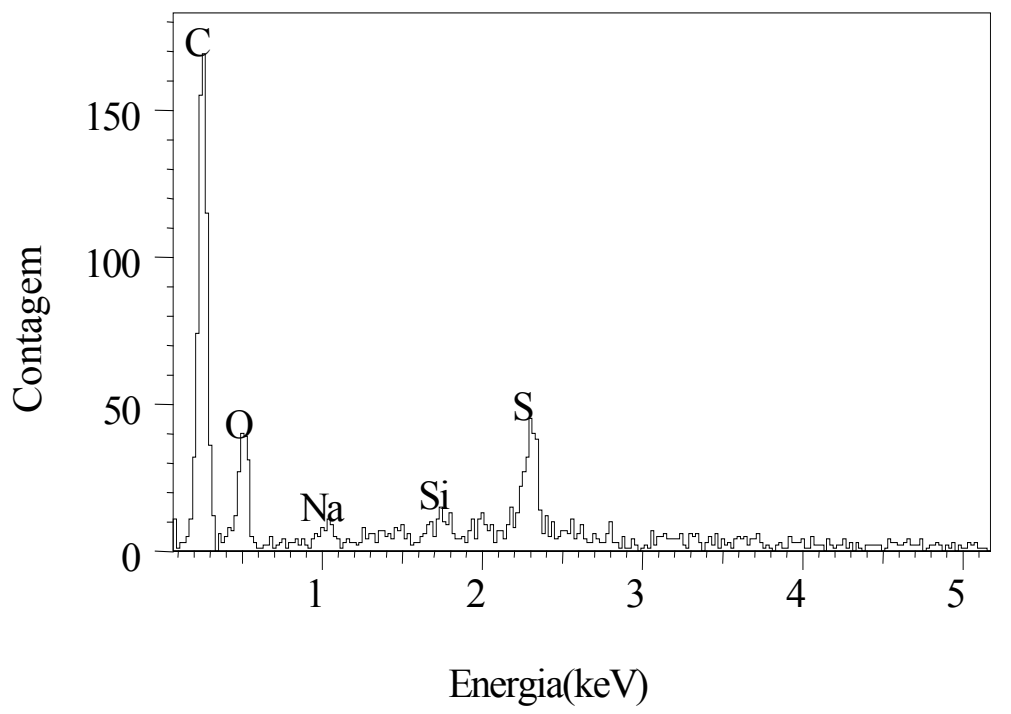

Figura 5.76. Intensidade da Quantidade de Energia Detectada pelo Equipamento de EDXRF em Amostras Coletadas na Altura Central do Reator.

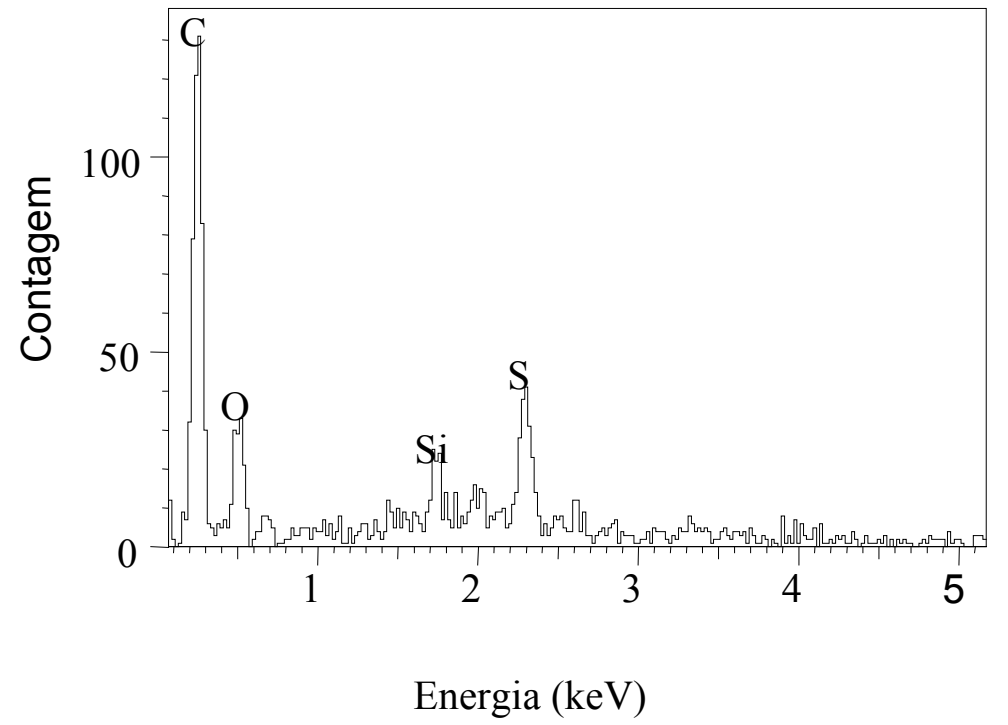

Figura 5.77. Intensidade da Quantidade de Energia Detectada pelo Equipamento de EDXRF em Amostras Coletadas na Altura Inferior do Reator.

Dessa forma, os resultados obtidos por EDXRF confirmaram que a maior parte do enxofre elementar produzido concentrou-se na superfície do reator, como mostra a Figura 5.78, onde ocorreu a maior relação em massa entre sólidos suspensos e MS (158 mg. mg $\left.{ }^{-1}\right)$. Amostras de MS do meio e fundo do reator apresentaram relação em massa entre SS e MS média de $23 \mathrm{mg} \cdot \mathrm{mg}^{-1}$. 
Tabela 5.42. Porcentagem em massa dos Elementos Detectados por EDXRF nos Sólidos Retidos em Espuma de Poliuretano

\begin{tabular}{cccc}
\hline & Superfície & Meio & Fundo \\
\hline Oxigênio & 27,2 & 62,5 & 63,1 \\
Sódio & n.d. & 7,0 & n.d. \\
Silício & n.d. & 5,4 & 9,7 \\
Enxofre & 71,1 & 25,1 & 27,2 \\
\hline
\end{tabular}

n.d.: Não Determinado

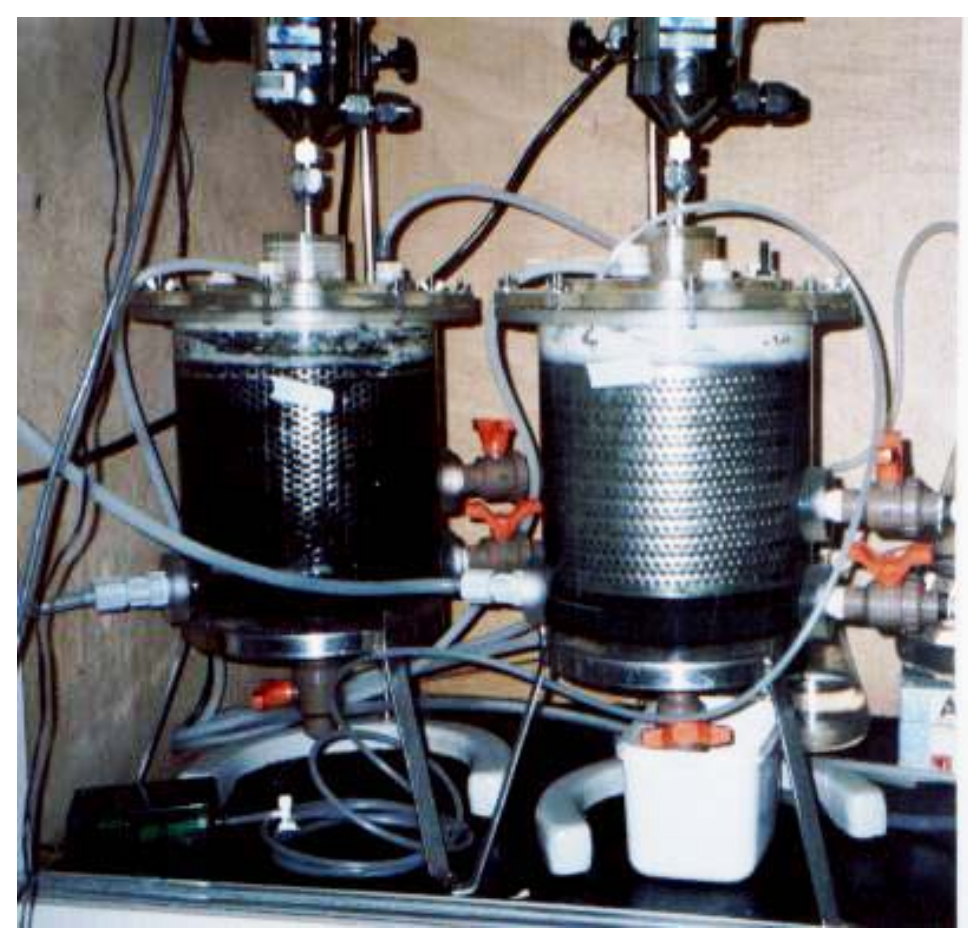

Figura 5.78. Reator Sulfetogênico, ASBBR (1) e Reator Aeróbio, SBBR (2).

$\mathrm{Na}$ Figura 5.78 pode ser observado enxofre aderido nas paredes da parte superior do reator aeróbio, bem como no reator ASBBR. Parte do enxofre na superfície foi formada por oxidação química do $\mathrm{H}_{2} \mathrm{~S}(\mathrm{~g})$ devido à introdução de oxigênio durante as operações de descarga dos reatores. Entretanto, exames de microscopia ótica revelaram a presença de morfologias em forma de bacilos com grânulos (possivelmente enxofre), em material raspado na parede do reator. Esses microrganismos também foram observados em amostras de PU que constituiu o material suporte. 


\section{CONCLUSÕES}

Os resultados obtidos nesse trabalho conduziram as seguintes conclusões:

I. A escolha correta do material suporte a ser utilizado em reatores anaeróbios com biomassa imobilizada é fundamental para se conseguir o melhor desempenho de processos biológicos empregados com diversas finalidades. As diferentes características entre os materiais suporte possíveis de serem utilizados, conduz a diferentes equilíbrios microbianos.

II. Entre os quatro tipos de materiais suporte avaliados: espuma de poliuretano (PU), carvão vegetal (CV), polietileno de baixa densidade reciclado (PE), e cerâmica porosa confeccionada com alumina (CE), BRS aderiram melhor em PU e CV.

III. No tratamento de água residuária sintética com relação $\mathrm{DQO} /\left[\mathrm{SO}_{4}{ }^{2-}\right]$ igual a 3,2 as BRS foram mais competitivas por substratos orgânicos e hidrogênio do que as BA e AM. Esse fato foi observado na análise de desempenho dos ASBBR's contendo biomassa imobilizada em PU e CV, e confirmado posteriormente por exame microbiológico pelo método de "hibridação in situ com fluorescência (FISH)".

IV. O ASBBR contendo CV como material suporte apresentou melhor desempenho em remoção de DQO e de sulfato do que o ASBBR contendo $\mathrm{PU}$, no tratamento de água residuária sintética com relação $\mathrm{DQO} /\left[\mathrm{SO}_{4}{ }^{2-}\right]$ igual a 3,2 .

V. Durante o tratamento de água residuária sintética com relação $\mathrm{DQO} /\left[\mathrm{SO}_{4}{ }^{2-}\right]$ igual a 1,3 não foi detectado metano no biogás gerado nos ASBBR's contendo biomassa imobilizada em PU e em CV. Metano pode ter sido produzido em pequena quantidade e utilizado como doador de elétrons para as BRS ou a atividade metanogênica pode ter sido completamente inibida na competição por substratos orgânicos e hidrogênio entre AM e BRS. 
VI. Os ASBBR's contendo PU e CV como materiais suporte apresentaram desempenhos iguais em remoção de DQO e redução de sulfato no tratamento de água residuária sintética com relação $\mathrm{DQO} /\left[\mathrm{SO}_{4}{ }^{2-}\right]$ igual a 1,3 .

VII. No tratamento de água residuária sintética com relação $\mathrm{DQO} /\left[\mathrm{SO}_{4}{ }^{2-}\right]$ igual a 0,4 os ASBBR's com PU e com CV tornaram-se completamente sulfetogênicos. Esse fato foi constatado pela inexistência de metano no biogás e confirmado por FISH, método pelo qual não se detectou arqueas metanogênicas na comunidade microbiana imobilizadas nos materiais suporte dos respectivos reatores.

VIII. Na condição de tratamento de água residuária sintética as bactérias acidogências foram mais competitivas pela matéria orgânica adicionada do que as BRS, fato comprovado pela baixa porcentagem de BRS detectadas pela sonda SRB385 em relação à porcentagem de bactérias detectadas pela sonda EUB358 na avaliação microbiana por FISH em PU e CV. Esses resultados justificam o pior desempenho em redução de sulfato no tratamento de água residuária sintética com relação $\mathrm{DQO} /\left[\mathrm{SO}_{4}{ }^{2-}\right]$ igual a 0,4 , comparado com os desempenhos obtidos no tratamento de água residuária sintética com relação DQO/[ $\left[\mathrm{SO}_{4}{ }^{2-}\right]$ igual a 3,2 e 1,3 .

IX. O tratamento de água residuária sintética com relação $\mathrm{DQO} /\left[\mathrm{SO}_{4}{ }^{2-}\right]$ igual a 1,3 foi o mais favorável para o processo de biodessulfatação.

X. A adição de etanol em quantidade estequiométrica à concentração de sulfato resultou em melhoramento do desempenho em redução de sulfato nos ASBBR's avaliados. Todavia ocorre aumento na concentração de ácidos voláteis, possivelmente, devido a oxidação incompleta do etanol a acetato pelas BRS. Dosagens de etanol superiores à estequiométrica é inviável para o processo de biodessulfatação. O acúmulo de Hac pode inibir as próprias BRS.

XI. A modelação cinética demonstrou ser uma importante ferramenta ser utilizada para identificação das rotas metabólicas ocorrendo em reatores anaeróbios no tratamento de águas residuárias contendo sulfato. As informações geradas pelo ajuste do modelo cinético a dados empíricos podem ser utilizadas para direcionar os processos biológicos de acordo com suas finalidades, ou seja, remoção de matéria orgânica concomitante com redução 
de sulfato ou operar o reator exclusivamente para reduzir sulfato.

XII. A utilização de reator aeróbio ( $\left.\mathrm{OD} \leq 0,1 \mathrm{mg} \cdot \mathrm{L}^{-1}\right)$ operado em bateladas seqüenciais e contendo biomassa imobilizada (SBBR) em PU demonstrou ser viável para o emprego do processo biológico de oxidação parcial do sulfeto a enxofre elementar. É possível recuperar enxofre do efluente desses reatores por sedimentação em unidades posteriores adequadamente projetadas. 


\section{RECOMENDAÇÕES PARA TRABALHOS FUTUROS ENVOLVENDO O PROCESSO DE BIODESSULFURIZAÇÃO (REMOÇÃO DE SULFATO E SULFETO)}

I. Estudar o fenômeno de transferência de massa visando melhorar o transporte de sulfato para o interior das células em reatores com células imobilizadas em suportes inertes ou auto-imobilizadas em grânulos.

II. Avaliar o efeito da toxicidade do íon acetato $\left(\mathrm{HCOO}^{-}\right)$sobre as $\mathrm{BRS}$ a fim de se estabelecer limites de concentração desse íon em reatores sulfetogênicos.

III. Estudar o processo de redução de sulfato em ASBBR utilizando uma mistura de $\mathrm{H}_{2} / \mathrm{CO}_{2}$ como doadores de elétrons e fonte de carbono para casos de águas residuárias com valores de relação $\mathrm{DQO} /\left[\mathrm{SO}_{4}{ }^{2-}\right]$ inferiores a 0,67.

IV. Avaliar a comunidade microbiana em reator aeróbio operado em bateladas seqüenciais com a finalidade de confirmar a presença de microrganismos que utilizam sulfeto e excretam enxofre elementar sob concentrações de oxigênio dissolvido igual ou inferiores a $0,1 \mathrm{mg} \cdot \mathrm{L}^{-1}$.

V. Avaliar a aplicabilidade industrial do enxofre elementar produzido biologicamente. 


\section{REFERÊNCIAS BIBLIOGRÁFICAS}

ADAMSON, A.W. (1990). Physical Chemistry of Surfaces, $5^{\text {th }}$ edition. A WileyInterciense publication.

AMANN, R. I.; BINDER, B. G.; OLSON, R. J.; CHRISHOLM, S. W.; DEVEREUX, R.; STAHL, D. A. (1990). Combination of 16S rRNA-target oligonucleotide probes with flow cytometry for analyzing mixed microbial populations. Applied Environmental Microbiology 56, p. 1919 - 1925.

APHA; AWWA; WPCF (1998) Standard Methods for the Examination of Water and Wastewater, $18^{\text {th }}$ Edition, American Public Health Association, Whashington.

ARAÚJO, J. C. (1995). Caracterização e evolução do biofilme em reator anaeróbio de leito fluidificado alimentado com esgoto sanitário sintético. Dissertação de Mestrado - SHS-EESC-USP, São Carlos, SP.

CADAVID, D. L.; ZAIAT, M.; FORESTI, E. (1999). Performance of horizontal flow anaerobic immobilized sludge (HAIS) reactor treating synthetic substrate subjected to decreasing COD to sulfate ratios. Water Science and Technology 39 (10-11), p. 99-106.

CALLADO, N. H. (1992). Estudo da toxicidade do sulfato em reator anaeróbio de manta de lodo (UASB). Dissertação de Mestrado - SHS-EESC-USP, São Carlos, SP.

CAMPOS, J. R. (1990). Proyecto y operación de filtros anerobios para tratamiento de efluentes líquidos industriales. Taller Regional y Conferencia sobre Tratamiento Anaeróbio de Aguas Residuales em América Latina. Ciudad Del México.

CENTRO DE DiVULGAÇÃO CIENTÍFICA E CULTURAL (CDCC). Enxofre. www.cdcc.sc.usp.br/elementos/enxofre.html.

COLLERAN, E.; FINNEGAN, S.; LENS, P. (1995). Anaerobic treatment of sulphate-containing waste streams. Antonie van Leeuwenboek 67, p. 24-46. 
CYBIS, 1. F.; PICKBRENNER K.; ARIMA, G. (2002). Inibição de processo aeróbio por sulfetos. Anais: XXVIII Congresso Interamericano de Ingeniería Sanitária y Ambiental, Cancun, México, 27 al 31 de octubre, 2002.

CUBAS, S.A. (2004) Influência do tamanho da biopartícula no desempenho de reatores anaeróbios em batelada contendo biomassa imobilizada para tratamento de águas residuárias. Tese de Doutorado - SHS-EESC-USP, São Carlos, SP.

CUBAS, S. A.; Foresti, E.; Rodrigues, J.A.D.; Ratusznei, S.M.; Zaiat, M. (2004). Influence of liquid-phase mass transfer on the performance of a stirred anaerobic sequencing batch reactor containing immobilized biomass. Biochemical Engineering Journal Amsterdam 17, p. 99-105.

DAGUE, R. R.; HABBEN, C. E.; PIDAPARTI, S. R. (1992). Initial studies on the anaerobic sequencing batch reactor. Water Science and Technology 26 (9-11), p. 2429-2432.

DEBASTIANI W.G. (2002). Resolução numérica utilizando o método Runge-Kutta 4 em Microsoft Excel ${ }^{\circledR}$ - www.geocities.com/giorgiodebastiani.

DEPARTAMENTO NACIONAL DE PRODUÇÃO MINERAL, DNPM (2004). Enxofre. Sumário Mineral 22a edição. www.dnpm.gov.br.

DILALLO, R.; ALBERTSON, E. (1961). Volatile acids by direct titration. Journal WPCF 33, p. 356-365.

DOMINGUES, M. R. (2002). Avaliação da metanogenese e sulfetogenese em reatores anaeróbios em batelada e de leito fixo, sob condições termofílicas. Dissertação de Mestrado - SHS-EESC-USP, São Carlos, SP.

DUGBA P. N.; ZHANG, R. (1999). Treatment of dairy wastewater with two-stage anaerobic sequencing batch reactor systems - thermophilic versus mesophilic operations. Bioresource Technology 68, p. 225 - 233.

FUTIWAKI L.; VARESCHE, M.B.; SILVA, E.L. (2004). Estudo da cinética de conversão de sulfeto a enxofre utilizando a sulfobactéria púrpura Chromatium vinosum DSM 183. III Seminário do Projeto Temático: "Desenvolvimento, Análise, Aprimoramento e Otimização de Reatores Anaeróbios para Tratamento de Águas Residuárias”. Escola de Engenharia de Mauá, São Caetano do Sul - SP.

HANSEN, T. A. (1994). Metabolism of sulfate-reducing prokaryotes. Antonie van Leeuwenhoek 66, p. 165-185. 
HARADA, H.; UEMURA, S.; MOMONOI, K. (1994). Interaction between sulfate reducing bacteria and methane producing bacteria in UASB reactors fed with low strength wastes containing different levels of sulfate. Water Research 28 (2), p. $355-367$.

HIRASAWA, J. S. (2003). Avaliação da comunidade microbiana anaeróbia em reator sulfetogênico utilizando a hibridação in situ com sondas fluorescentes. Dissertação de Mestrado, SHS-EESC-USP, São Carlos, SP.

HOLT, JOHN G. (1994). Bergey's manuel of determinative bacteriology, 9 edtition. Baltimore : Williams \& Williams.

ISA, Z., GRUSENMEYER, S.; VERSTRAETE, W. (1986a). Sulfate reduction relative to methane production in high-rate anaerobic digestion: Technical aspects. Applied and Environmental Microbiology, p. 572-579.

ISA, Z., GRUSENMEYER, S.; VERSTRAETE, W. (1986b). Sulfate reduction relative to methane production in high-rate anaerobic digestion: Microbiological Aspects. Applied and Environmental Microbiology, p. 580-587.

JANSEN, A. J. H.; LETTINGA, G.; KEIZER, A. DE (1999). Removal of hydrogen sulphide from wastewater and waste gases by biological conversion to elemental sulphur - coloidal and interfacial aspects of biologically produced sulphur particles. Colloids and Surfaces, A: Phisicochemical and Engineering Aspects 151, pp. 389-397.

LANGE A. N. (1978). Handbook of chemistry 12. ed. New York : Macgraw-Hill.

LAWRENCE, A.W.; MCCARTY, P.L. (1966). The effects of sulfides on anaerobic treatment. Air and Water Pollut Int J. 10, p. 207-221.

LENS, P. N. L.; VISSER A.;. JANSSEN, A. J. H; HULSHOFF POL, L. W; LETTINGA G. (1998). Biotechnological treatment of sulfate-rich wastewaters. Critical Reviews in Environmental science and technology 28 (1), p. 41-88.

LENS P. N. L.; SIPMA, J.; HULSHOFF POL, L. W.; LETTINGA G. (2000). Effect of nitrate on acetate degradation in a sulfidogenic staged reactor. Water Research 34 (1), p. $31-42$.

LEVENSPIEL, O. (1999). Engenharia das Reações Químicas. Editora Edgard Blücher Ltda. 
LY, Y. Y.; LAM, S.; FANG, H. H. P. (1995). Interactions between methanogenic sulfate-reducing and syntrophic acetogenic bacteria in the anaerobic degradation of benzoate. Water Reserarch 30 (7), p. $1555-1562$.

MADIGAN, M. T.; MARTINKO, J. M.; PARKER, J. (1997). Brook biology of microorganisms. Prentice-Hall Inc.

MAILLACHERUVU, K. Y.; PARKIN, G. F.; PENG, C. Y.; KUO, W.; OONGE, Z. I.; LEBDUSCHKA V. (1993). Sulfide toxicity in anaerobic systems fed sulfate and various organics. Water Environment Research 65 (2), p. 100 - 109.

MAILLACHERUVU, K. Y.; PARKIN, G. F. (1996). Kinetics of growth, substrate utilization and sulfide toxicity for propionate, acetate, and hydrogen utilizers in anaerobic systems. Water Environment Research 68 (7), p. 1.099 - 1.106.

MANZ, W.; AMANN, R.; LUDWIG, W.; WAGNER, M.; SCHLEIFER, K. (1992). Phylogenetic oligodeoxynucleotide probe for the major subclasses of Proteobacteria: problems and solutions. Systematic Applied Microbiology 15, p. $593-600$.

METCALF \& EDDY (1991). Wastewater Engineering - Treatment, Disposal and Reuse. McGraw-Hill International Editions, Civil Engineering Series.

MUÑOZ, M. A.; SANCHEZ, J. M.; RODRIGUEZ-MAROTO, J. M.; BORREGO, J. J.; MORIÑIGO, A. M. (1997). Methane production in anaerobic sludges supplemented with two support materials and different levels of acetate and sulphate. Water Research 31 (5), p. 1236-1242.

MIZUNO, O.; LI, Y., Y.; NOIKE, T. (1994). Effects of sulfate concentration and sludge retention time on the interactions between methane production and sulfate reduction for butyrate. Water Sciense and Technology 30 (8), p. 45 - 54.

MIZUNO, O.; LI, Y., Y.; NOIKE, T. (1998). The behavior of sulfate-reducing bacteria in acidogenic phase of anaerobic digestion. Water Research 32 (5), p. 1626-1634.

MORAES, E. M.; ADORNO, M. A. T.; ZAIAT, M.; FORESTI, E. (2000). Determinação de ácidos voláteis por cromatografia gasosa em efluentes de reatores anaeróbios tratando resíduos líquidos e sólidos. Anais, Vol. II da Oficina e Seminário Latino Americano sobre Digestão Anaeróbia, Recife/Pe. 
NATION, L. L. (1983). A new method using hexamethyldisilazane for preparation of softs tissues for scaning electron microscopy. Stain Technology 58, p. 347-351.

O'FlAHERTY, V.; COLOHAN, S.; MULKERRINS, D.; COLLERAN, E. (1999). Effect of sulphate addition on volatile fatty acid and ethanol degradation in an anaerobic hybrid reactor. II: microbial interactions and toxic effects. Bioresource Technology 68, p. 109-120.

OMIL, F.; LENS, P.; POL HULSHOFF, W.; LETTINGA (1997). Characterization of biomass from a sulfidogenic, volatile fatty acid-degrading granular sludge reactor. Enzyme and Microbial Technology 20, p. 229 - 236.

ORGANIZAÇÃO DAS NAÇÕES UNIDAS (1992). Declaração universal dos direitos da água. http://www.uniagua.org.br. Consulta realizada em janeiro/2005.

PASSIG, F. H. (1997). Estudo do desenvolvimento do biofilme e dos grânulos formados no filtro biológico anaeróbio. Dissertação de Mestrado - SHS-EESCUSP, São Carlos, SP.

PAULA JR., D. R. DE (1992). Toxicidade em reatores anaeróbios de manta de lodo (UASB): efeitos do aumento progressivo na concentração inicial de sulfeto. Tese de Doutorado, SHS-EESC-USP, São Carlos, SP.

PEREZ RODRIGUEZ, J.L.; M.I. CARRETERO; C. MAQUEDA (1989). Behaviour of sepiolite, vermiculite and montmorillonite as supports in anaerobic digesters. Applied Clay Science 4, p. 69-82.

PETHICA B. (2000). Microbial and cell adhesion. In: Berkeley R. C. W. et al. Microbial adhesion to surfaces. London. Society of chemical industry. Cap. 1, p. $19-45$.

PICANÇO, A. P; VALLERO, M. V. G.; GIANOTTI, E. P.; ZAIAT, M.; BLUNDI, C.E. (2001). Influence of porosity and composition of supports on the methanogenic biofilm characteristics developed in a fixed bed anaerobic reactor. Water Science and Technology 44(4), p. 197-204.

RASKIN, L.; STROMLEY, J. M.; RITTMAN, B. E.; STAHL, D. A. (1994). Group specific 16S rRNA hybridization probes to describe natural communities of methanogens. Applied Environmental Microbiology 60, p. 1232 - 1240.

RATUSZNEI, S. M., RODRIGUES, J. A. D., CAMARGO, E. F. .M, ZAIAT, M., BORZANI, W. (2000). Feasibility of a Stirred Anaerobic Sequencing Batch 
Reactor COntaining Immobilized Biomass for Wastewater Treatment. Bioresource Technology 75(2), p. 127-132.

RIBEIRO, R. (2001). Influência do tipo de substrato na dinâmica de formação do biofilme em matrizes de espuma de poliuretano. Dissertação de Mestrado, SHSEESC-USP, São Carlos, SP.

RYPLEY, L. E; BOYLE, W. C.; CONVERSE, J. C. (1986). Improved alkalimetric monitoring for anaerobic digestion of high-strength wastes. Journal of Water Pollution Control Federation 58, p. 406-411.

SAKAMOTO, I. K. (1996). Comportamento do consórcio microbiano existente em um lodo anaeróbio granulado metanogênico, submetido a adições crescentes de sulfato. Dissertação de Mestrado - SHS-EESC-USP, São Carlos, SP.

SCHMIT C. G.; DAGUE, R. R. (1993). Anaerobic sequencing batch reactor treatment of swine wastes at $20^{\circ} \mathrm{C}, 25^{\circ} \mathrm{C}$, e $35^{\circ} \mathrm{C} .48^{\text {th }}$ Purdue Industrial Waste Conference Proceedings. Lewis Publishers, USA.

SILVA, A. J. DA (1999). Remoção de sulfato de água residuária industrial utilizando reator anaeróbio de leito fixo. Dissertação de Mestrado - SHS-EESC-USP, São Carlos.

SILVA, A. J.; VARESCHE, M. B.; FORESTI, E.; ZAIAT, M. (2002). Sulphate removal from industrial wastewater using a packed-bed anaerobic reactor. Process Biochemistry 37(9), p. 927-935.

SMUL, A. de; J. GROOTAERD, D. L. G. H.; VERSTRAETE, W. (1997). High rates of microbial sulphate reduction in a mesophilic ethanol-fed expanded-granularsludge-blanket reactor. Appl Microbiol Biotechnol 48, p. 297-303.

SPEECE R. E. (1983). Anaerobic biotechnology for industrial Wastewaters. Environment Science technology 17(9), p. 416A-427A.

SPEECE R. E. (1996). Anaerobic biotechnology for industrial Wastewaters. Aarchae Press.

STAMS, ALFONS J. M. (1994). Metabolic interactions between anaerobic bacteria in methanogenic environments. Antonie van Leeuwenhoek 66, p. 271-294.

TIMUR, H.; ÖZTURK, I. (1999). Anaerobic sequencing batch reactor treatment of landfill leachate. Water Research 11 (15), p. 3225 - 3230. 
TOMMASO, G. (1999). Estrutura, caracterização e cinética de lodo anaeróbio imobilizado em espuma de poliuretano tratando substrato sintético. Dissertação de Mestrado, SHS-EESC-USP, São Carlos, SP.

TORRES, P. (1992). Desempenho de um reator anaeróbio de manta de lodo (UASB) de bancada no tratamento de substrato sintético simulando esgoto sanitário sob diferentes condições de operação. Dissertação de Mestrado - SHS-EESC-USP, São Carlos.

VAZOLler, R. F.; MONTENEGRO, M. A. P; CALlADO, N. H; FORESTI, E. (1996). Uma proposta para o metabolismo do sulfato em um biodigestor anaeróbio de fluxo ascendente e manta de lodo, operado com glicose, acetato e metanol. $11^{\circ}$ Simpósio Nacional de Fermentações, São Carlos.

VELA, F. J.; ZAIAT M.; FORESTI E. (2002). Influence of the COD to sulphate ratio on the anaerobic organic matter degradation Kinetics.Water AS 28 (2), p. 213-216.

VERRIER D.; MORTIER B., ALBAGNAC, G. (1988) Initial adhesion of methanogenic bacteria to polymers. Biotechnology Letters 9(10), p. 735 - 740.

VISSER, A.; HULSHOFF POL; LETTINGA, G. (1996). Competition of methanogenic and sulfidogenic bacteria. Water Science and Technology 33 (3), p. 99-110.

WIRTZ, R. A.; DAGUE, R. R.; (1997). Laboratory studies on enhancement of granulation in the anaerobic sequencing batch reactor. Water Science and Technology 36 (4), p. $279-286$.

ZAIAT, M.; CABRAL, A.K.A.; FORESTI, E. (1994).Reator anaeróbio horizontal de leito fixo para tratamento de águas residuárias: concepção e avaliação preliminar de desempenho. Revista Brasileira de Engenharia - Caderno de Engenharia Química 11 (2), p. 33-42.

ZAIAT, M.; RODRIGUES, J. A. D.; RATUZNEI, S. M. (2001). Anaerobic sequencing batch reactors for wastewater treatment: a developing technology. Applied Microbiology Biotechnology 55, p. 29 - 35. 